UNIVERSIDADE DE SÃO PAULO

ESCOLA DE ENGENHARIA DE SÃO CARLOS - EESC

GILL BUKVIC

ESTRATÉGIA DE USINAGEM EM VERDE DIRIGIDA AO PROJETO DE PEÇAS CERÂMICAS

São Carlos

2015 
GILL BUKVIC

\title{
ESTRATÉGIA DE USINAGEM EM VERDE DIRIGIDA AO PROJETO DE PEÇAS
} CERÂMICAS

\begin{abstract}
Tese apresentada à Escola de Engenharia de São Carlos da Universidade de São Paulo para obtenção do título de Doutor em Engenharia Mecânica.
\end{abstract}

Área de Concentração: Projeto Mecânico

Orientador: Prof. Dr. Carlos Alberto Fortulan.

ESTE EXEMPLAR TRATA-SE DA VERSÃO CORRIGIDA. A VERSÃO ORIGINAL ENCONTRA-SE DISPONÍVEL JUNTO AO DEPARTAMENTO DE ENGENHARIA MECANICA DA EESC-USP.

São Carlos 
AUTORIZO A REPRODUÇÃO TOTAL OU PARCIAL DESTE TRABALHO, POR QUALQUER MEIO CONVENCIONAL OU ELETRÔNICO, PARA FINS DE ESTUDO E PESQUISA, DESDE QUE CITADA A FONTE.

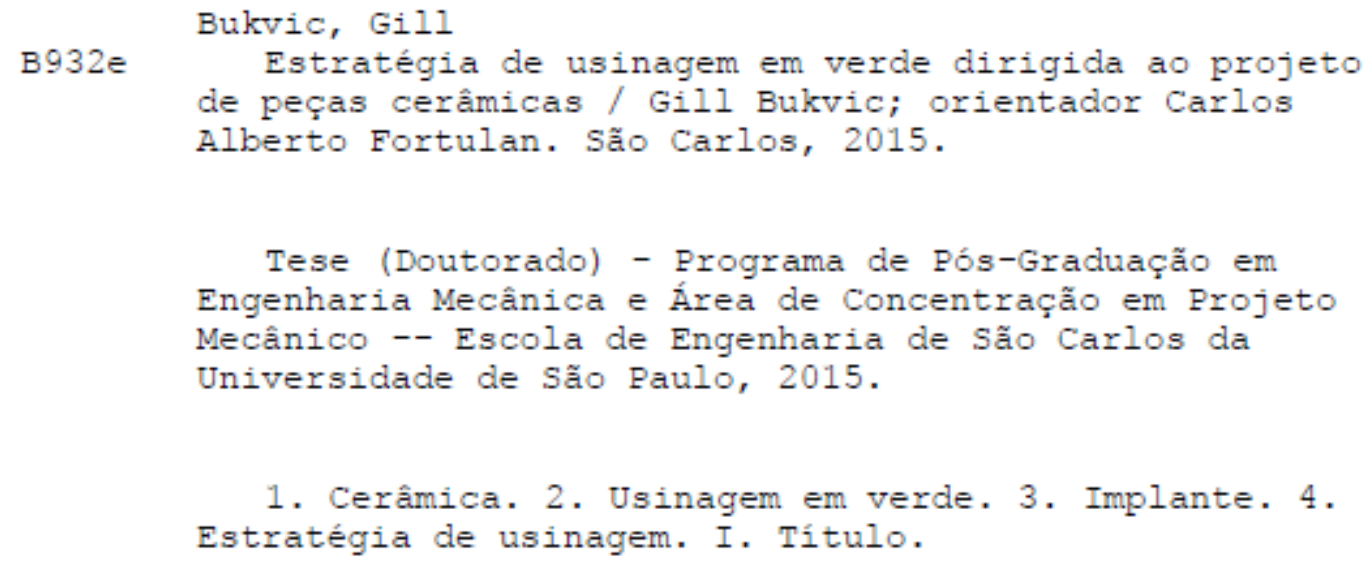




\section{FOLHA DE JULGAMENTO}

Candidato: Engenheiro GILL BUKVIC.

Título da tese: "Estratégia de usinagem a verde dirigida ao projeto de corpos cerâmicos ".

Data da defesa: 16/10/2015

Comissão Julgadora:

Prof. Associado Carlos Alberto Fortulan

(Orientador)

(Escola de Engenharia de São Carlos/EESC)

Prof. Associado Renato Goulart Jasinevicius

(Escola de Engenharia de São Carlos/EESC)
Resultado:

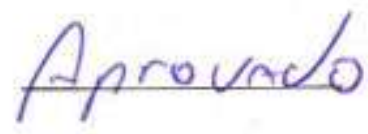

Prof. Dr. Luis Eduardo de Angelo Sanchez

APROVADO

(Universidade Estadual Paulista"Júlio de Mesquita Filho" - UNESP - Bauru)

Prof. Dr. Eduardo Carlos Blanchi

APROVADO

(Universidade Estadual Paulista"Júlio de Mesquita Filho" - UNESP - Bauru)

Profa. Dra. Vera Lúcia Arantes

APROVADO

(Escola de Engenharia de São Carlos/EEȘC)

Coordenador do Programa de Pós-Graduação em Engenheira Mecânica:

Prof. Associado Gherhardt Ribatski

Presidente da Comissão de Pós-Graduação:

Prof. Associado Paulo César Lima Segantine 


\section{DEDICATÓRIA}

Dedico este trabalho a minha esposa Luiza e a meus pais Gilberto e Teresa. 


\section{AGRADECIMENTOS}

Primeiramente, agradeço a DEUS, por todas as bênçãos recebidas durante esta trajetória e permitir que eu alcançasse mais essa vitória.

A minha ESPOSA Luiza, obrigado por todo o apoio, compreensão e por estar sempre ao meu lado me encorajando e acreditando em meu potencial.

Aos meus PAIS Gilberto e Teresa, aos quais devo a minha vida e tudo o que sou, e à minha IRMÃ Mariana. Com eles, aprendi valores e princípios que levarei por toda a vida. Obrigado pelo incentivo e por sempre acreditarem no meu potencial.

Aos meus CUNHADOS Junior, Maira, Rodrigo e Claudia, obrigado pelo apoio e suporte quando precisei.

Ao meu ORIENTADOR Carlos Alberto Fortulan, obrigado por sua contribuição ao longo de todo o desenvolvimento desse trabalho. Agradeço 0 empenho, a dedicação, a confiança e a paciência. Serei sempre grato por ter me ajudado a conquistar mais essa vitória.

Ao TÉCNICO e AMIGO Luiz Adalberto Penazzi, obrigado por seu suporte no desenvolvimento desse trabalho.

Aos meus AMIGOS Arthur, Camila, Giovana e Karen, que, de maneiras distintas, contribuíram para a execução deste trabalho.

Ao PROFESSOR Benedito de Moraes Purquerio, pela atenção despendida quando precisei.

Aos PROFESSORES Renato Goulart Jacinevicius e Luiz Eduardo de Ângelo Sanchez, obrigado pela contribuição com a medição de rugosidade, o que auxiliou no desenvolvimento do trabalho.

A CAPES (Coordenação de Aperfeiçoamento de Pessoal de Nível Superior), pela bolsa de estudos concedida.

Agradeço a todos que, de forma direta ou indireta, contribuíram para a consumação de mais uma etapa em minha vida. 


\section{RESUMO}

\section{BUKVIC, G., Estratégia de usinagem em verde dirigida ao projeto de peças}

cerâmicas. 2015. 190 f. Tese (Doutorado) - Escola de Engenharia de São

Carlos, Universidade de São Paulo, São Carlos, 2015.

Este trabalho trata da usinagem em verde aplicada ao projeto de corpos cerâmicos, quanto a sua morfologia e propriedades requeridas e inclui estratégia de usinagem para seleção do processo, parâmetros de corte e ferramentas. A usinagem em verde é uma técnica estruturada na filosofia do near-net-shape e vem sendo amplamente aplicada na fabricação de peças cerâmicas de formatos variados e complexos, a exemplo de implantes ósseos. Por ser aplicada em compactos de baixa resistência mecânica exige precauções e controle sobre as forças aplicadas na usinagem. $O$ trabalho objetiva a elaboração de uma matriz de decisão para estratégia de usinagem em verde para a seleção e tomada de decisões, que baseada em um produto, possa direcionar aspectos relativos à formulação de ligantes cerâmicos, tratamentos pós-conformação, ferramentas, equipamentos e parâmetros de usinagem. Foram preparados grânulos de aluminas, baseados em ligantes PVAI, PVB e acrílicos B-1022 e B-1007, compactados na forma de cilindros, blocos e de cones. $\mathrm{Na}$ usinagem foram empregadas ferramentas com abrasivos de diamante, CBN e alumina eletrofundida com ligante metálico, resinoide e vitrificado. Operações representativas da usinagem foram selecionadas e aplicadas na geração de cilindros, barras e furos. Seletivamente foram realizadas medidas de torque de usinagem e forças tangenciais desenvolvidas durante o corte em verde. A resistência mecânica à flexão foi medida em verde e após sinterização, enquanto a rugosidade foi medida após a sinterização. Os resultados mostram uma forte correlação entre resistência em verde dos compactados brutos e esforços de corte e foram observadas particularidades para cada ligante cerâmico aplicado e para cada tipo de abrasivo e ligante utilizado nas ferramentas. Como melhores resultados, de peças usinadas com rebolo de alumina eletrofundida, foram encontradas resistência mecânica em verde de 7,8 MPa em peças com ligante acrílico B1022, resistência mecânica após sinterização de $342,6 \mathrm{MPa}$ em peças com ligante de PVB, potência consumida de 192,2 W em peças com ligante PVAl, rugosidade de 0,761 $\mu \mathrm{m}$ em peças com o ligante acrílico B-1007, e com ferramenta de diamante uma força de corte de $0,222 \mathrm{~N}$ foi obtida em peças com ligante PVAl. É concluído que há um forte compromisso entre todas as variáveis estudadas e que o formato e dimensão do produto, bem como seu 
acabamento e propriedades requeridas, podem ser fortemente influenciadas pelas condições do compactado e da usinagem empregada. Como solução mais notável, se tem o uso do ligante acrílico B-1007 prensado a $200 \mathrm{MPa}$, ferramenta com abrasivo de diamante de granulometria \#80 mesh com ligante metálico, onde foi observado o compromisso de alta resistência em verde (para suportar os esforços), baixo empastamento de rebolo, baixa força de corte, baixa potência consumida, acabamento superficial e integridade das bordas. A matriz de decisão para estratégia de usinagem em verde desenvolvida foi aplicada na fabricação de um implante dentário conceitual free-form e foi validada pelo sucesso da obtenção desta peça.

Palavras-chave: cerâmica, usinagem em verde, implante, estratégia de usinagem. 


\section{ABSTRACT}

\section{BUKVIC, G., Green machining directed to the project of ceramic parts.}

2015. 190 f. Tese (Doutorado) - Escola de Engenharia de São Carlos, Universidade de São Paulo, São Carlos, 2015.

This paper deals with the green machining applied to the project of ceramic parts, specifically with its morphology and required properties and includes machining strategy to the selection of the process, cutting parameters and tools. Green machining is a structured near-net-shape technique philosophy and has widely been applied in the ceramic parts manufacturing with varied and complex shapes such as bone implants. For being applied in low mechanical strength compacts parts it requires precautions and control over the forces used during the machining process. This work aims the development of a decision matrix for a machining green strategy to provide a selection and a decision-making that, based on a product, will direct aspects relating to the ceramic binders formulation, post-forming treatments, tools, required equipment and machining parameters. Alumina granules were prepared based on binders such as PVAl, PVB, acrylics B-1022 and B-1007, compacted in the form of cylinders, blocks and cones. In the machining itself it was applied tools with diamond, CBN and eletrofused alumina abrasives with metal, resinoid and vitrified binders. Representing machining operations were selected and applied in order to form cylinders, bars and holes. Were made selectively measures of machining torque and tangential forces, developed during the green cutting. The flexural mechanical strength was measured in green and after sintering while the surface roughness was measured after the sintering. The results demonstrate a strong correlation between only the green strength of the rough compacted parts and the cutting forces and it was observed the particularities of each ceramic binder applied and each kind of the abrasive and binder used in the tools. As best results, machining using eletrofused alumina grinding wheel obtained green strength up to $7.8 \mathrm{MPa}$ in parts with B-1022 acrylic binder, mechanical strength after sintering up to $342.6 \mathrm{MPa}$ in parts with PVB binder, power consumption up to $192.2 \mathrm{~W}$ in parts with PVAl binder, surface roughness up to $0.761 \mu \mathrm{m}$ in parts with B-1007 acrylic binder and with diamond tool a cutting force up to $0,222 \mathrm{~N}$ was obtained in parts with PVAl binder. As a conclusion, it can be said that there is a strong commitment between all the studied variables and the format and size of the product, as well as its finishing and required properties can be strongly influenced by the conditions of the compacted parts and the machining used. The most remarkable solution, has 
been the use of B-1007 acrylic binder compacted at $200 \mathrm{MPa}$, diamond abrasive tool with grain size of \#80 mesh with metal binder, where was observed a high green strength commitment (to withstand the stresses), low grinding wheel clogging, low cutting force, low power consumption, surface finishing and edges integrity. The developed decision matrix for the strategy of a green machining was applied for a free-form conceptual dental implant manufacturing and has been validated by the obtainment of this part with success.

Keywords: ceramic, green machining, implants, machining strategy. 


\section{LISTA DE FIGURAS}

Figura 2.1 - Mapa para processos tecnológicos (RODEL et al., 2009). .30

Figura 2.2 - Processo de produção corrente de componentes cerâmicos (AMERICAN MACHINIST, 1991 apud SCHELLER, 1994).

Figura 2.3 - Grãos de alumina obtidos por secagem por pulverização em diferentes magnificações (a, b, c e d), é possível, na superfície de um grânulo, obervar as partículas cerâmicas (BUKVIC, 2011).

Figura 2.4 - Representação esquemática dos processos de secagem por pulverização, (a) sentido da corrente e (b) contra-corrente (BOCH e NIÈPCE, 2007, adaptado).

Figura 2.5 - Princípios da prensagem isostática (a) de molde molhado e (b) molde seco (BOCH e NIÈPCE, 2007, adaptado). 35

Figura 2.6 - Superfícies das peças obtidas por diferentes pressões de compactação (DESFONTAINES et al., 2005).

Figura 2.7 - Fratura das peças em verde A prensadas a 10 e $100 \mathrm{MPa}$ (DESFONTAINES et al., 2005)

Figura 2.8 - Fratura das peças em verde B prensadas a 10 e $100 \mathrm{MPa}$ (DESFONTAINES et al., 2005).

Figura 2.9 - Fratura das peças em verde C prensadas a $10 \mathrm{MPa}$ (DESFONTAINES et al., 2005).

Figura 2.10 - Seis diferentes mecanismos podem contribuir para a sinterização de uma massa consolidada de partículas cristalinas: (1) difusão superficial, (2) difusão de rede da superfície, (3) transporte de vapor, (4) difusão no contorno de grão, (5) difusão de rede na fronteira do grão e (6) fluxo plástico. Somente mecanismos 1, 2 e 3 levam a densificação, mas todos causam o crescimento do pescoço e, portanto, influenciam na velocidade de densificação (RAHMAN, 2005, adaptado).

Figura 2.11 - Diagrama tensão deformação, demonstrando o efeito do peso molecular do ligante (ANDER, LEHMANN e ZIEGLER, 1997).

Figura 2.12 - Indução de microtrincas pela retificação, (a) magnitude de 100X e (b) magnitude de 2000X (LUTHARDT et al., 2004).

Figura 2.13 - O DCM na rápida manufatura de componentes técnicos (FILSER, KOCHER e GAYCKLER, 2003).

Figura 2.14 - Comportamento da compactação de pó de alumina granulada e recuperada (WESTERHEIDE et al., 1997). 
Figura 2.15 - Configuração de uma peça com paredes finas (EL-WARDANY et al., 2009)

Figura 2.16 - Compactado de carboneto de silício com a parte interna em seu formato final (EL- WARDANY et al., 2009. adaptado).

Figura 2.17 - Retificação de perfil de cerâmica em verde em um torno vertical (SHEPPARD, 1999).

Figura 2.18 - Modelo com dois rebolos perfilados (REM et al., 2002).....................55

Figura 2.19 - Protótipos de máquinas (FILSER, KOCHER E GAUCKLER, 2003)....55

Figura 2.20 - Máquina CNC de 5 eixos aplicada na usinagem em verde (ELWARDANY et al., 2009, adaptado).

Figura 2.21 - Desgaste para ferramentas de diferentes materiais na usinagem em verde de um compactado de nitreto de silício pré-sinterizado na fabricação por colagem de reação (RICHERSON, 1992, adaptado).

Figura 2.22 - Peças usinadas em verde utilizando ferramentas (a) revestidas de carboneto e (b) revestidas de diamante (DHARA e SU, 2005, adaptado)......59

Figura 2.23 - Micro broca com abrasivo de diamante: (a) configuração, (b) imagem de MEV magnificada e (c) ponta da micro broca com maior magnificação (LEE e LEE, 2004). 59

Figura 2.24 - Características da superfície usinada utilizando ferramenta revestida de diamante (a) arredondada e (b) plana (DHARA e SU, 2005, adaptado)....60

Figura 2.25 - Exemplo de um tipo de imagem utilizada para acessar os lascamento no lado da saída da ferramenta de uma peça em verde furada (DEGNAN, KENNEDY e SHIPWAY, 2007, adaptado).

Figura 2.26 - Tamanho médio de lascamento em relação ao nível de Kenolube adicionado, sendo as peças compactadas a $85 \mathrm{MPa}$ (DEGNAN, KENNEDY e SHIPWAY, 2007).

Figura 2.27 - Corpo-de-prova antes de fixado à base (a), fixado (b), usinado (c) e destacado (d) (BUKVIC, 2011).

Figura 2.28 - Peças usinadas em verde, produto (a) e (b). (LIU et al., 2010, adaptado).

Figura 2.29 - Diâmetros dos micros furos em verde e sinterizado: (a) diâmetro de entrada do micro furo; (b) diâmetro de saída do micro furo; (c) diâmetro do micro furo antes e após a sinterização; (d) placa de microcanais (LEE e LEE, 2004).

Figura 2.30 - Motor ultrassônico: (a) fotografia ótica do estator em formato de moinho de vento fabricado pela usinagem em verde termoplástica; (b) 
fotografia ótica da montagem experimental do estator tipo moinho de vento (YOON et al., 2007, adaptado).

Figura 2.31 - Coroas dentaria cerâmicas usinadas em verde (a) e sinterizadas (b), apresentando precisão micrométrica (RITZHAUPT-KLEISSL et al., 2006, adaptado).

Figura 2.32 - (a) usinagem em verde CNC e (b) modelo de um molar dentário de cerâmica sinterizada (SU, DHARA e WANG, 2008, adaptado).

Figura 2.33 - Rugosidade das peças em verde e depois da sinterizaçao no final de cada sobrematerial (BUKVIC et al., 2012). ................................................68

Figura 3.1 - Matriz de decisão para estratégia de usinagem em verde. ..................76

Figura 3.2 - Matriz de decisão para estratégia de usinagem em verde parcial na fabricação de uma barra com perfil retangular a partir de um bloco conformado. .79

Figura 3.3 - MEV dos abrasivos utilizados nas ferramentas. .82

Figura 3.4 - Banco de ensaio para usinagem de barras de perfil retangular. .83

Figura 3.5 - Operação do corte dos corpos de prova, sendo (a) planejamento e (b) execução. 84

Figura 3.6 - Rampa de aquecimento e temperatura do processo de sinterização....85

Figura 3.7 - Matriz de decisão para estratégia de usinagem em verde parcial na fabricação de um cilíndrico a partir de um tarugo de perfil redondo conformado. 88

Figura 3.8 - Banco de ensaio para usinagem de tarugos de perfil redondo.

Figura 3.9 - Operação do corte dos corpos de prova, sendo (a) planejamento e (b) execução.

Figura 3.10 - Matriz de decisão para estratégia de usinagem em verde parcial na fabricação de uma barra de perfil retangular com uma superfície funcional a partir de um bloco conformado.

Figura 3.11 - Mesa aerostática para medição das forças de usinagem. 100

Figura 3.12 - Banco de ensaio para usinagem de uma barra de perfil retangular com uma superfície funcional.

Figura 3.13 - Operação do corte dos corpos-de-prova, sendo (a) planejamento e (b) execução. 101

Figura 3.14 - Matriz de decisão para estratégia de usinagem em verde parcial para a obtenção de um furo em um bloco conformado. 104

Figura 3.15 - Banco de ensaio para usinagem de tarugos de perfil redondo. 107 
Figura 3.16 - Operação de furação do bloco, sendo (a) planejamento e (b)

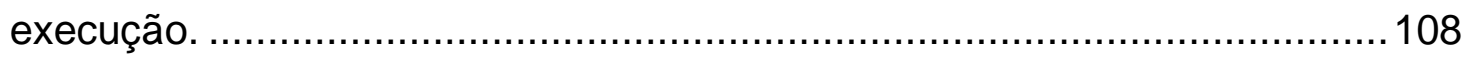

Figura 3.17 - Desenho em CAD do implante dentário conceitual free-form. ..........109

Figura 3.18 - Matriz de decisão para estratégia de usinagem em verde na fabricação de um implante dentário conceitual free-form a partir de um tarugo cônico conformado.

Figura 3.19 - Tarugo cônico de alumina em verde compactado a 200 MPa em prensa isostática.

Figura 3.20 - Molde para prensagem isostática tipo wet-bag de um tarugo cônico. Em (a) partes do molde e (b) molde montado. 112

Figura 3.21 - Imagem do mini centro de usinagem (MDX-40) da Roland DG Ltda.114

Figura 3.22 - Imagem do habitáculo de usinagem da máquina. 114

Figura 3.23 - Primeira etapa, operação de desbaste do corpo inferior do implante conceitual. 115

Figura 3.24 - Segunda etapa, operação de acabamento do corpo inferior do implante conceitual. 116

Figura 3.25 - Terceira etapa, operação de desbaste do corpo superior do implante conceitual. 116

Figura 3.26 - Quarta etapa, operação de acabamento do corpo superior do implante conceitual.

Figura 3.27 - Quinta etapa, operação de acabamento da ponta do corpo superior do implante conceitual.

Figura 4.1 - Defeitos de borda ocorridos durante a usinagem. 119

Figura 4.2 - Tensões máximas de ruptura obtidas em função do material da ferramenta e do ligante utilizados. 120

Figura 4.3 - Rugosidade média aritmética (Ra) obtida em função do material da peça e do ligante utilizados

Figura 4.4 - Matriz de decisão para estratégia de usinagem em verde na fabricação de uma barra com perfil de seção retangular a partir de um bloco conformado.

Figura 4.5 - Tensões máximas de ruptura em verde obtidas em função do ligante utilizado e da pressão de compactação. 123

Figura 4.6 - Lascamentos de borda ocorridos durante a usinagem, em função do tipo de ligante, dos compactados prensados a $100 \mathrm{MPa}$.

Figura 4.7 - Lascamentos de borda ocorridos durante a usinagem, em função do tipo de ligante, dos compactados prensados a $200 \mathrm{MPa}$ 125 
Figura 4.8 - Retração linear obtida em função do ligante utilizado.

Figura 4.9 - Torque de usinagem obtido em função do ligante utilizado.

Figura 4.10 - Rugosidade média aritmética ( $R a$ ) obtida em função dos ligantes utilizados.

Figura 4.11 - Tensões máximas de ruptura a flexão obtidas em função do ligante utilizado.

Figura 4.12 - Densidade aparente obtida em função do ligante utilizado e da pressão de compactação.

Figura 4.13 - MEV das superfícies dos corpos-de-prova com os diferentes ligantes cerâmicos.

Figura 4.14 - Lascamentos de borda ocorridos durante a usinagem, em função da concentração do ligante acrílico B-1007, dos compactados prensados a 200 $\mathrm{MPa}$

Figura 4.15 - Retração linear obtida em função da concentração do ligante acrílico B-1007. 134

Figura 4.16 - Torque de usinagem obtido em função da concentração do ligante acrílico B-1007. 135

Figura 4.17 - Tensões máximas de ruptura a flexão obtidas em função da concentração do ligante acrílico B-1007. 136

Figura 4.18 - Rugosidade média aritmética obtida em função da concentração do ligante acrílico B-1007. 136

Figura 4.19 - Matriz de decisão para estratégia de usinagem em verde na fabricação de um cilindro a partir de um tarugo de perfil redondo conformado 138

Figura 4.20 - Variação do material e ligante da ferramenta em função da força de corte. 140

Figura 4.21 - Variação do material e ligante da ferramenta em função do valor da massa de material aderida.

Figura 4.22 - Rugosidade média aritmética $(\mathrm{Ra})$ para a variação do material e ligante da ferramenta em função do ligante cerâmico.

Figura 4.23 - Superfícies usinadas utilizando ferramenta de abrasivo de diamante com ligante metálico (D 181) para os diferentes ligantes cerâmicos. 142

Figura 4.24 - Análise da velocidade de corte em função da força de corte. 144

Figura 4.25 - Análise da velocidade de corte em função rugosidade média aritmética (Ra). 144

Figura 4.26 - Análise da velocidade de avanço em função da força de corte. 146 
Figura 4.27 - Análise da velocidade de avanço em função rugosidade média aritmética $(\mathrm{Ra})$.

Figura 4.28 - Análise da profundidade de corte em função da força de corte.

Figura 4.29 - Análise da profundidade de corte em função rugosidade média aritmética $(\mathrm{Ra})$.

Figura 4.30 - Variação do tamanho de grão e material da ferramenta em função da força de corte.

Figura 4.31 - Variação do tamanho de grão e material da ferramenta em função do valor da massa de material aderida.

Figura 4.32- MEV das superfícies das ferramentas.

Figura 4.33 - Análise das ferramentas em função da rugosidade média aritmética $(\mathrm{Ra})$.

Figura 4.34- Variação do tamanho de grão e material da ferramenta. 153

Figura 4.35 - Matriz de decisão para estratégia de usinagem em verde na fabricação de uma barra com uma superfície funcional plana a partir de um bloco conformado. 155

Figura 4.36 - Tentativas de furação com a retificação frontal. 156

Figura 4.37 - Imagem da vista superior do corpo-de-prova. 158

Figura 4.38- Imagem da vista inferior do corpo-de-prova. 159

Figura 4.39 - Imagem do fundo dos furos arrancados pelos processos. 159

Figura 4.40 - Detalhe das furações obtidas como os dois processos. 160

Figura 4.41 - Matriz de decisão para estratégia de usinagem em verde na obtenção de um furo em um bloco conformado.

Figura 4.42 - Progressão da usinagem do implante dentario conceitual, sendo (a) operação de desbaste e (b) operação de acabamento. 162

Figura 4.43 - Implante dentário conceitual, em (a) usinado em verde e (b) sinterizado. 163

Figura 4.44 - Quebra do implante durante o processo de usinagem quando aplicado um parâmetro de usinagem inadequado. 


\section{LISTA DE TABELAS}

Tabela 2.1 - Propriedades de diferentes misturas de alumina compactadas sinterizadas a $1700^{\circ} \mathrm{C}$ (TAKTAK, BAKLOUTI e BOUAZIZ, 2011).

Tabela 2.2 - Especificação do abrasivo de diamante da micro broca (LEE e LEE, 2004). 60

Tabela 3.1 - Família básica de formatos de peças em função do processo de

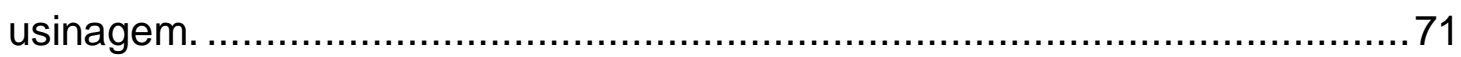

Tabela 3.2 - Tipos de máquinas em função do tipo de comando...........................72

Tabela 3.3 - Ferramentas básicas em função do tipo de material e da máquina. ....74

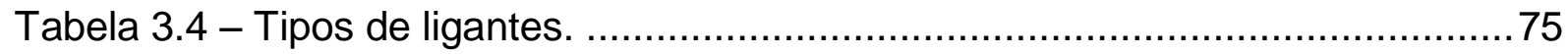

Tabela 3.5 - Denominação das formulações. ………............................................. 80

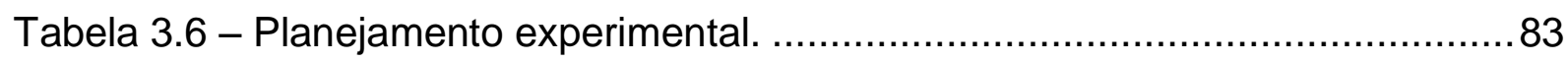

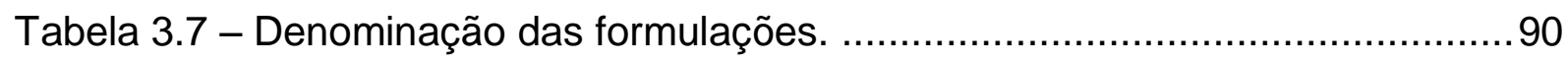

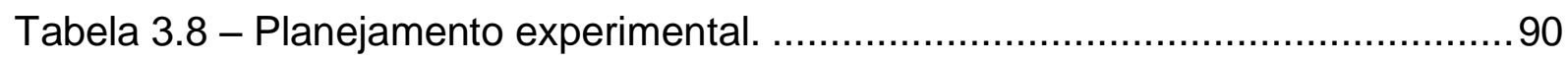

Tabela 3.9 - Denominação das formulações. …………...................................97

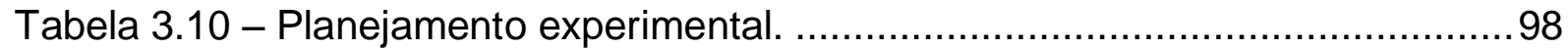

Tabela 3.11 - Denominação da formulação. ........................................................ 105

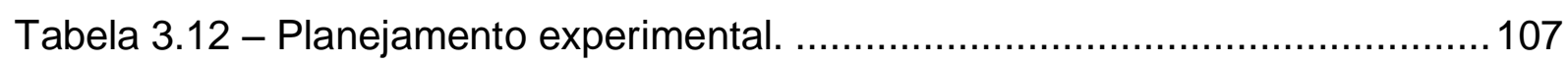

Tabela 3.13 - Denominação da formulação. ....................................................112

Tabela 3.14 - Planejamento experimental. ....................................................113

Tabela 4.1 - Planejamento experimental para análise da velocidade de corte.......143

Tabela 4.2 - Planejamento experimental para análise da velocidade de avanço. .. 145

Tabela 4.3 - Planejamento experimental para análise da profundidade de corte... 147 


\section{LISTA DE SIGLAS}

$\begin{array}{ll}\text { ASTM } & \text { American Society for Testing and Materials } \\ \text { CAD } & \text { Computer-aided design } \\ \text { CAM } & \text { Computer-aided manufacturing } \\ \text { STL } & \text { Stereolithography } \\ \text { CBN } & \text { Nitreto de boro cúbico } \\ \text { DCM } & \text { Direct ceramic machining } \\ \text { CNC } & \text { Controle Numérico Computadorizado } \\ \text { EESC } & \text { Escola de Engenharia de São Carlos } \\ \text { MEV } & \text { Microscopia eletrônica de varredura } \\ \text { PCD } & \text { Diamante poli cristalino } \\ \text { PVAl } & \text { Poli (álcool vinílico) } \\ \text { PVB } & \text { Poli (butiral vinílico) } \\ \text { PEG } & \text { Poli (glicol etilênico) } \\ \text { TG } & \text { Tecnologia de grupo } \\ \text { UNESP } & \text { Universidade Estadual Paulista } \\ \text { USP } & \text { Universidade de São Paulo } \\ & \end{array}$




\section{LISTA DE SÍMBOLOS}

\begin{tabular}{|c|c|}
\hline$a_{p}$ & Profundidade de corte (mm) \\
\hline$a_{e}$ & Largura de corte (mm) \\
\hline${ }^{\circ} \mathrm{C}$ & Grau Celsius \\
\hline $\mathrm{D}$ & Diâmetro \\
\hline Ds & Diâmetro da haste \\
\hline$f$ & Velocidade de avanço (mm/min) \\
\hline g & Grama \\
\hline $\mathrm{g} / \mathrm{cm}^{3}$ & Grama por centímetro cúbico \\
\hline $\mathrm{kN}$ & Kilo Newton \\
\hline $\mathrm{L}$ & Comprimento total \\
\hline Lc & Cutoff \\
\hline Ld & Comprimento do revestimento \\
\hline $\mathrm{m}$ & Metro \\
\hline $\mathrm{MPa}$ & Mega Pascal \\
\hline$M_{t}$ & Torque de usinagem (N.m) \\
\hline $\mathrm{mm}$ & Milímetro \\
\hline $\mathrm{mm} / \mathrm{min}$ & Milímetro por minuto \\
\hline $\mathrm{mm}^{2} / \mathrm{g}$ & Milímetro quadrado por grama \\
\hline $\mathrm{mm}^{3} / \mathrm{min}$ & Milímetro cúbico por minuto \\
\hline $\mathrm{m} / \mathrm{s}$ & Metro por segundo \\
\hline$n$ & Rotação (rpm) \\
\hline $\mathrm{N} / \mathrm{mm}$ & Newton por milímetro \\
\hline N.m & Newton metro \\
\hline $\mathrm{P}_{\mathrm{u}}$ & Potência de usinagem (W) \\
\hline $\mathrm{Ra}$ & Rugosidade média aritmética $(\mu \mathrm{m})$ \\
\hline rpm & Rotações por minuto \\
\hline TG & Temperatura de transição vítria \\
\hline
\end{tabular}


$\mathrm{v}_{\mathrm{c}}$

$V_{f}$

W

Y-TZP

$\mu \mathrm{m}$

Velocidade de corte $(\mathrm{m} / \mathrm{s})$

Velocidade de avanço da peça $(\mathrm{mm} / \mathrm{min})$

Watt

Zircônia tetragonal estabilizada com ítria

Micrometro 


\section{SUMÁRIO}

1 INTRODUÇÃO

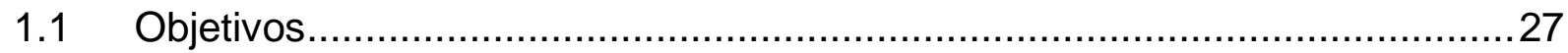

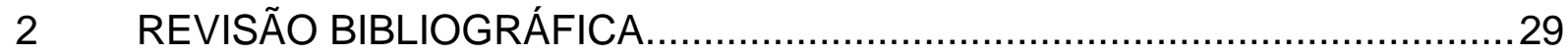

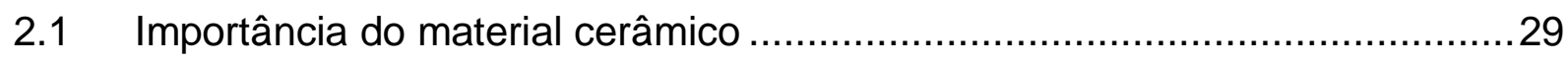

2.2 Produção de uma peça cerâmica.............................................................

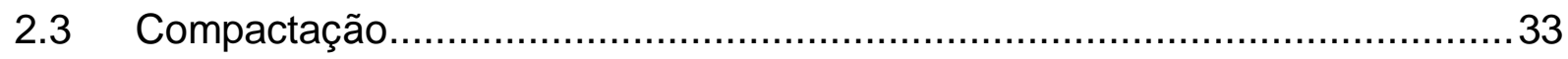

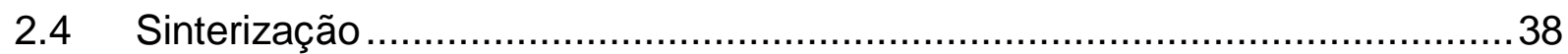

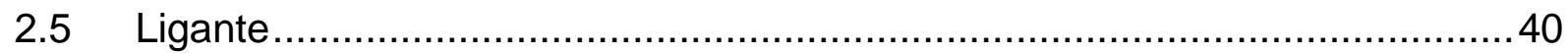

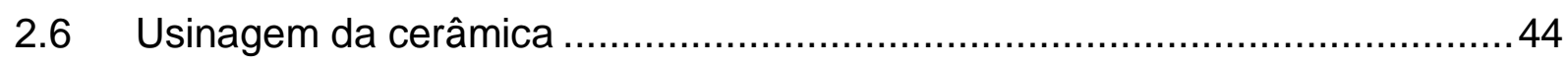

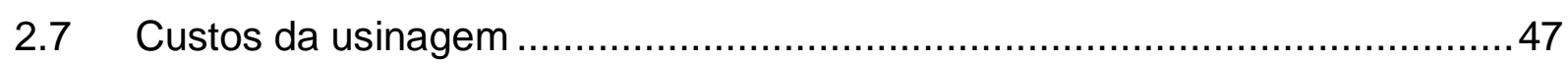

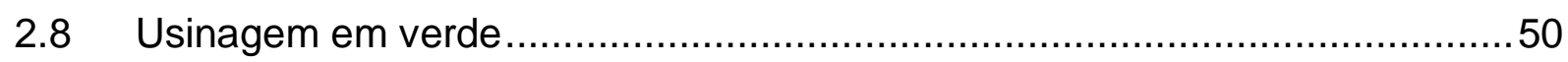

2.8.1 Influência do ligante na usinagem em verde .........................................52

2.8.2 Máquinas para usinagem em verde .........................................................

2.8.2.1 Exemplos de máquinas aplicadas em usinagem em verde .....................54

2.8.2.2 Nível de acabamento alcançado por cada tipo de máquina .....................56

2.8.3 Efeito do material da ferramenta na usinagem em verde ............................56

2.8.4 Efeito da geometria da ferramenta na usinagem em verde .........................60

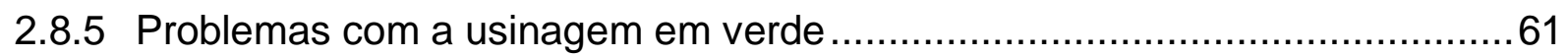

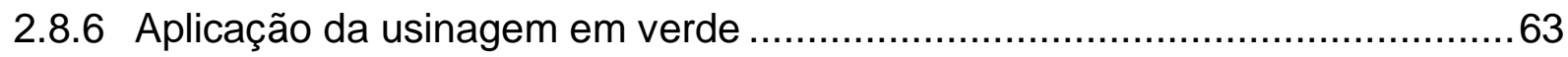

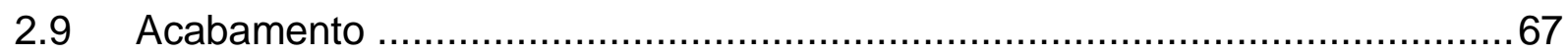

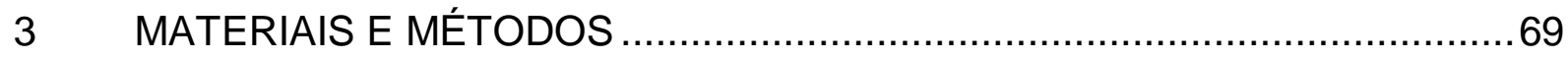

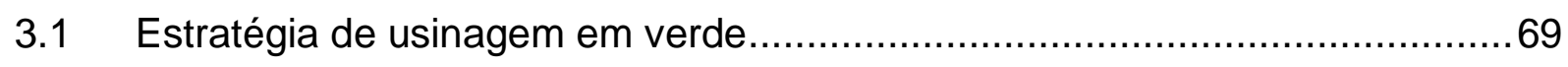

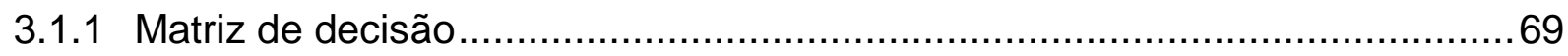

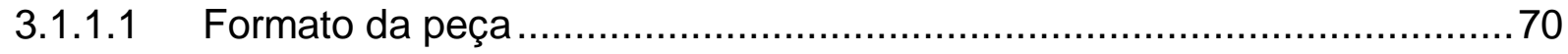

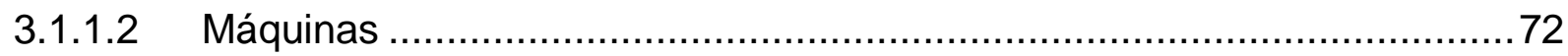

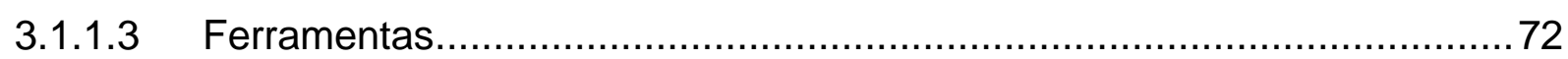

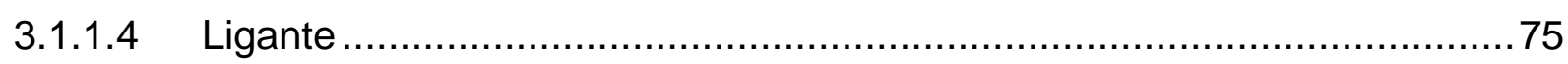

3.1.1.5 Matriz de decisão para estratégia de usinagem em verde ......................75

3.2 Estudo de caso de usinagem em verde ……........................................77 
3.2.1 Estratégia de usinagem em verde na fabricação de uma barra com perfil retangular (Ensaio Preliminar) ............................................................. 77

3.2.1.1 Preparação dos corpos de prova ………........................................ 80

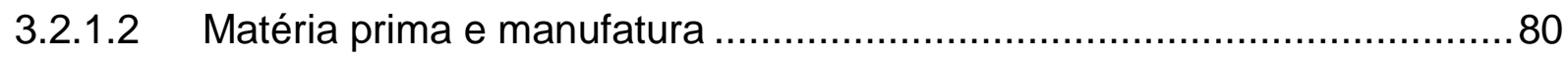

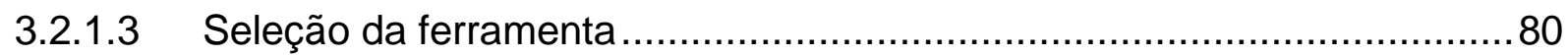

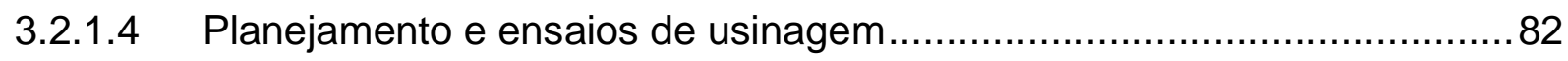

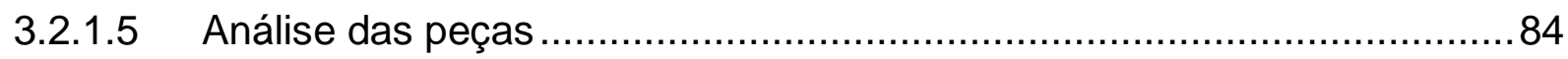

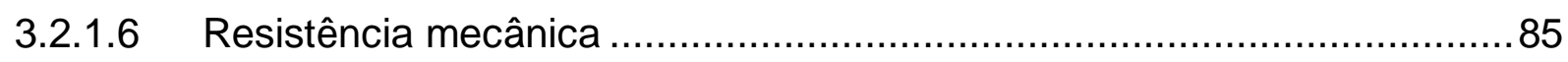

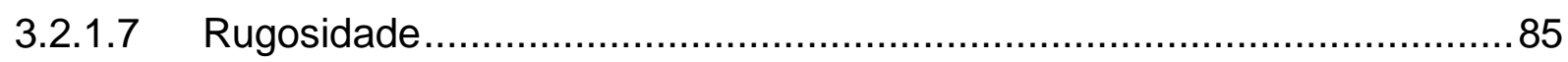

3.2.2 Estratégia de usinagem em verde na fabricação de um cilindro ....................86

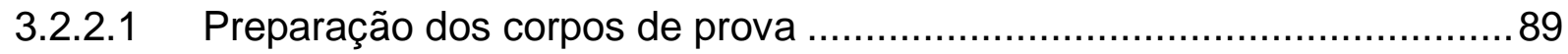

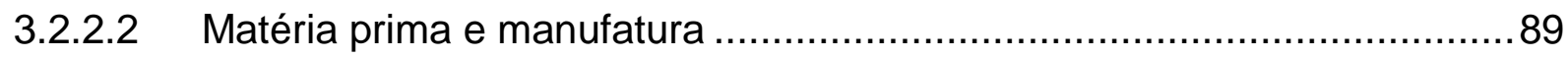

3.2.2.3 Planejamento e ensaios de usinagem .............................................. 90

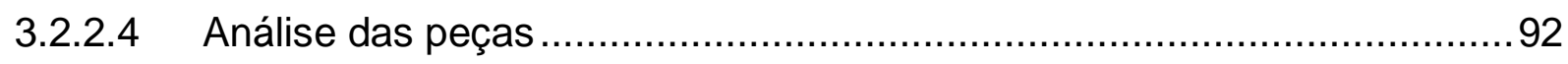

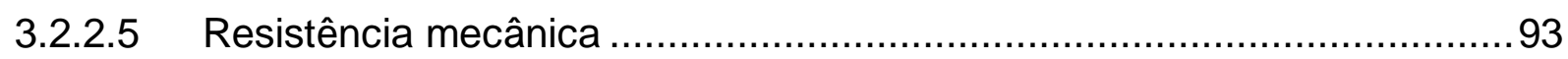

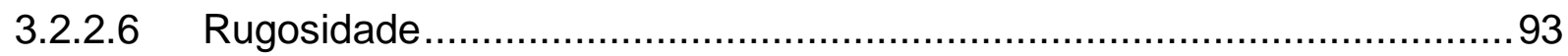

3.2.3 Estratégia de usinagem em verde na fabricação de uma barra de perfil retangular com uma superfície funcional plana ............................................93

3.2.3.1 Preparação dos corpos de prova ………….......................................

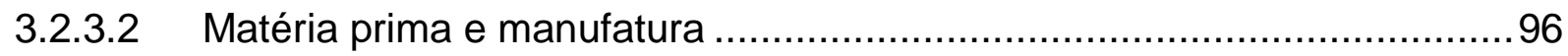

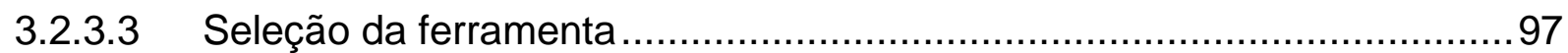

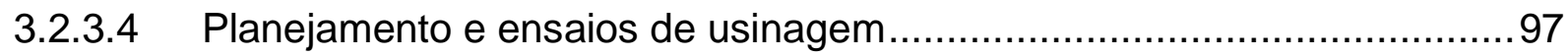

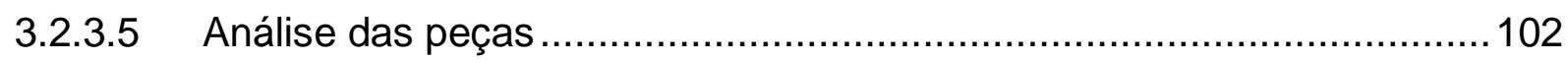

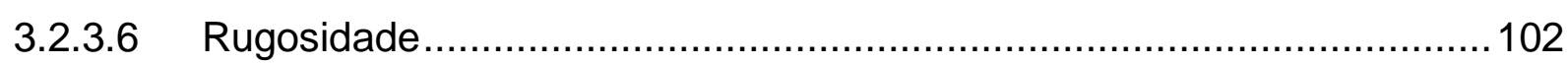

3.2.4 Estratégia de usinagem em verde para a obtenção de um furo ..................102

3.2.4.1 Preparação dos corpos de prova .................................................... 105

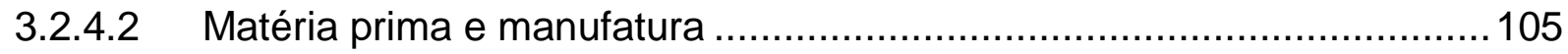

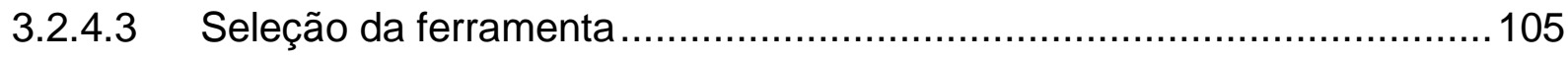

3.2.4.4 Planejamento e ensaios de usinagem ............................................. 106

3.2.5 Estratégia de usinagem em verde na fabricação de um implante dentário

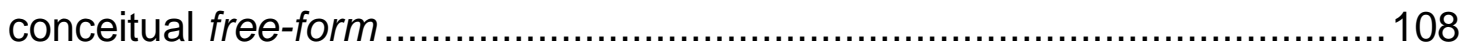

3.2.5.1 Preparação do corpo de prova .......................................................111

3.2.5.2 Matéria prima e manufatura ………………..................................112 


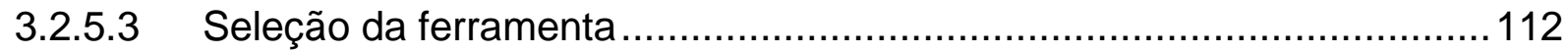

3.2.5.4 Planejamento e ensaios de usinagem .............................................113

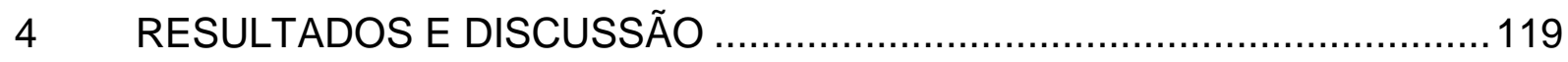

4.1 Resultados do estudo de caso de usinagem em verde .............................119

4.1.1 Resultados da estratégia de usinagem em verde na fabricação de uma barra com perfil de seção retangular (Ensaio preliminar) .....................................119

4.1.1.1 Resolução da estratégia de usinagem em verde na fabricação de uma barra com perfil retangular.

4.1.2 Resultados da estratégia de usinagem em verde na fabricação de um

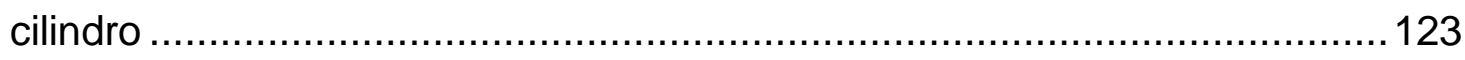

4.1.2.1 Análise da variação da concentração de ligante ..................................133

4.1.2.2 Resolução da estratégia de usinagem em verde na fabricação de um cilindro

4.1.3 Resultados da estratégia de usinagem em verde na fabricação de uma superfície funcional plana

4.1.3.1 Análise do material e ligante da ferramenta aplicado a diferentes ligantes cerâmicos

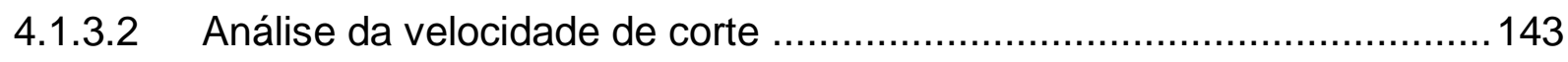

4.1.3.3 Análise da velocidade de avanço ....................................................... 145

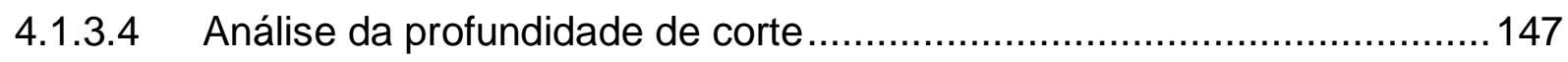

4.1.3.5 Análise do tamanho de grão e material da ferramenta .........................150

4.1.3.6 Resolução da Estratégia de usinagem em verde na fabricação de uma superfície funcional plana ................................................................... 153

4.1.4 Resultados da estratégia de usinagem em verde na obtenção de um furo .. 156

4.1.4.1 Resolução da estratégia de usinagem em verde na obtenção de um furo..... 160

4.1.5 Resultados da estratégia de usinagem em verde na fabricação de um

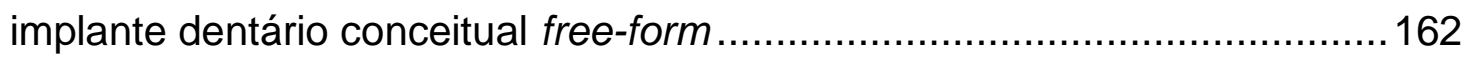

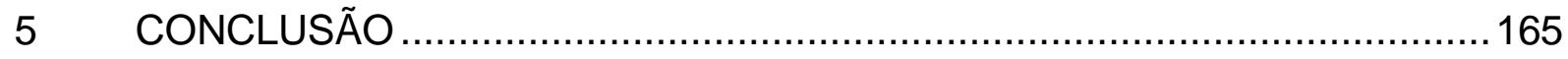

6 SUGESTÕES PARA TRABALHOS FUTUROS …...............................167

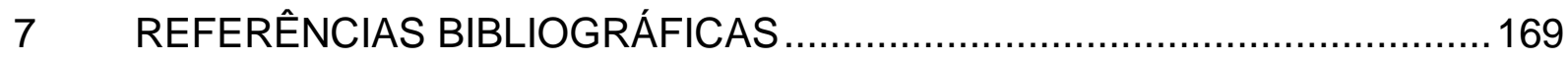

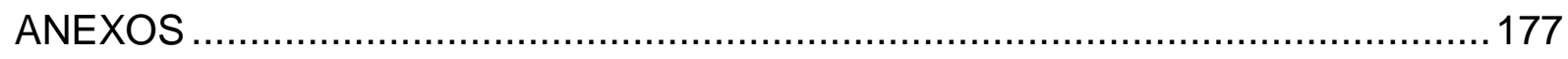





\section{INTRODUÇÃO}

O emprego de materiais cerâmicos avançados, tais como a alumina, o nitreto de silício, o carboneto de silício e a zircônia, têm aumentado expressivamente na atualidade, sendo auxiliado pelo custo destes produtos que têm se tornado acessíveis. Parte responsável pela redução do custo é devido à manufatura de alto desempenho, também mais acessível nos dias de hoje.

As vantagens das cerâmicas sobre outros materiais incluem as propriedades físicas, químicas e eletrônicas, bem como: alta dureza, alta resistência mecânica, alta resistência ao desgaste a altas temperaturas, estabilidade química, baixa densidade, inércia química, semicondução, refratariedade, condutividade iônica, entre outras.

Essas vantagens nas propriedades podem ser encontradas em aplicações como: rolamentos de precisão para o uso na indústria nuclear; componentes automotivos (sensores, isolantes, catalisadores, pistões, insertos, válvulas, forros); implantes biocompatíveis (próteses dentárias, jaquetas dentárias, substituição de ossos, válvulas cardíacas); peças de desgaste (sede de válvulas, selos mecânicos, guias); refratários (placas isolantes de forração de foguetes, forros militares, componentes para fornos); substratos, bases e isoladores em componentes eletrônicos (ARGWAL e RAO, 2008).

Apesar de suas excelentes propriedades, as cerâmicas avançadas estruturais são populares somente para uma fatia de produtos, pois para outras fatias é limitada devido a sua natureza frágil (SHEPPARD, 1992).

A fabricação industrial de peças cerâmicas é, em sua maioria, feita a partir da sinterização de pós compactados e, de forma assídua, necessitam ser usinados nas dimensões e acabamento especificados (NG, HULL e HENSHALL, 2006; BORGER et al., 2002).

Embora a tecnologia do processamento do pó seja amplamente utilizada em muitas indústrias, é necessário know-how para obter produtos com alta qualidade e baixo custo. Por exemplo, os processos de manufatura podem influenciar significativamente as propriedades das cerâmicas avançadas. Para um dado método de produção, a menor mudança na condição do processamento do pó pode causar uma grande influência na qualidade do produto cerâmico (FORTULAN E PURQUERIO, 1998; NAITO e ABE, 2004 apud NAITO et al., 2010). 
Em produtos onde o acabamento superficial, a precisão dimensional e de forma são exigidos, a usinagem se faz necessária. A usinagem de cerâmicas sinterizadas consome tempo e energia, além de requerer equipamentos específicos, extremamente rígidos e equipados com ferramentas de extrema dureza, a exemplo do diamante. Consequentemente, essa operação é muito dispendiosa e pode representar até $80 \%$ do custo da produção de uma peça cerâmica.

Para auxiliar a fabricação, pode-se empregar antes da sinterização a usinagem em verde, que é até 1000 vezes mais rápida do que a usinagem da cerâmica sinterizada e pode ser efetuada com quase todas as ferramentas e técnicas utilizadas nos metais, por isso é uma técnica amplamente utilizada na fabricação de componentes cerâmicos (DESFONTAINES, 2005; LINDQVIST e CARLSTROM, 2002; SHINOHARA e TANAKA, 1975 apud BORTZMEYER, LANGGUTH e ORANGE, 1993).

A usinagem em verde da cerâmica é uma técnica de baixo custo. Contudo, a usinabilidade das peças cerâmicas neste estado em verde depende de vários fatores, tais como: resistência mecânica da cerâmica em verde, resistência ao lascamento e desgaste de ferramenta. Embora alta resistência em verde seja um fator desejado, quando se requer a usinagem, peças com resistência em verde extremamente alta se tornam frágeis o que dificulta muito as operações de furações, fresamentos e torneamentos convencionais, causando lascamento de borda ou, até mesmo, quebra da peça. Usualmente aditivos, a exemplo de plastificantes, são adicionados aos pós para reduzir a natureza frágil e melhorar as características de usinagem das peças cerâmicas em verde (WU e MACNANY, 1995 apud PRABHAKARAN et al., 2001; BIRKBY et al., 1994; SHEPPARD, 1992).

Pesquisas em usinagem em verde de cerâmica ainda são poucas e o knowhow é principalmente empírico e mantido sob sigilo industrial, o que dificulta a disseminação e o compartilhamento técnico científico globalizado. Muitos problemas permanecem para serem resolvidos a fim de tornar a usinagem em verde mais abrangente, como, por exemplo, dispositivos de fixação, a extração dos cavacos de usinagem, geometria de ferramenta, entre outros. O ponto mais crítico a ser investigado é a caracterização da usinabilidade das peças verdes. Indústrias se baseiam na experiência, sendo muito difícil predizer a resistência à usinagem de uma peça em verde e qual será a melhor estratégia para realizar o trabalho (DESFONTAINES, 2005).

SHINOHARA, K.; TANAKA, T. Ultimate tensile strength of cohesive powders based on non-uniform packing model. J. Chem. Ing. Japan, v. 8, p. 50-6, 1975.

WU, X.L.K.; MCANANY, W.J. Acrylic binder for green machining, Am. Ceram. Soc. Bull. V. 74, p. 61-64, 1995. 
A remoção de defeitos superficiais e subsuperficiais, bem como a correção de deformações devida a não uniformidade de densidade adquirida no processo de conformação, pode ser uma estratégia para a recomendação decisiva da usinagem em verde, que se feita em conjunto com a conformação pode simplificar o processo e os moldes de conformação (BUKVIC, 2011).

Apesar de já se ter uma longa tradição industrial da usinagem em verde, a precisão dimensional após a sinterização de produtos em novos projetos é insatisfatória, pois parâmetros não otimizados e homogeneidade limitada dos pós compactados resultam em contração não homogênea e em distorções macroscópicas. Em produções seriadas, geralmente são feitos ajustes específicos durante a produção industrial para a obtenção da precisão dimensional desejada.

Novas práticas de condicionamento do pó e novos métodos de compactação têm sido desenvolvidos, os quais melhoram a homogeneidade para usinagem (FILSHER, KOCHER e GAUCKLER, 2003). Isso, juntamente com a utilização de máquinas controladas numericamente por computador (CNC), as quais permitem a obtenção de melhor produtividade e qualidade das peças usinadas em verde (SHEPPARD, 1999).

Este trabalho tem como hipótese que a usinagem em verde quando tratada de maneira estratégica e planejada permitirá: a obtenção de produtos de formatos simples e complexos, a minimização de defeitos superficiais, a maximização da qualidade dimensional e de forma, a minimização de sobrematerial para usinagem e consequente otimização do custo de manufatura.

\subsection{Objetivos}

O objetivo desse trabalho é o estudo da usinagem de cerâmica em verde aplicada ao projeto de produtos cerâmicos, dando ênfase à forma dos produtos na usinagem e nas propriedades (resistência mecânica e acabamento superficial) requeridas para os mesmos, que foram expressos em uma matriz de decisão para estratégia de usinagem em verde. Nessa inclui a seleção da melhor técnica de usinagem, seleção dos melhores parâmetros de corte, seleção de tipos e perfis das ferramentas de corte e análise dos diferentes aditivos orgânicos dos pós cerâmicos. Seu motivo é a obtenção econômica de produtos cerâmicos com maximização das propriedades mecânicas, contemplando a exigência de design, tolerância 
dimensional e acabamento superficial. Sendo a validação da matriz feita em um estudo de caso da fabricação de um implante dentário conceitual. 


\section{REVISÃO BIBLIOGRÁFICA}

Este capítulo aborda de maneira sistemática os principais tópicos relacionados à produção de peças em cerâmica avançada, relatando sua importância, produção, custos, usinagem, problemas e exemplos de aplicação.

\subsection{Importância do material cerâmico}

A cerâmica pode associar propriedades tais como: inércia química, alta dureza, baixa expansão térmica, alta refratariedade, semicondutividade, isolamento elétrico, alta rigidez e em determinadas aplicações, não pode ser substituída por outros materiais. Tais propriedades proporcionam o desempenho de numerosos dispositivos e equipamentos, porém, podem ser influenciadas pelo tipo de manufatura empregada (FANTOZZI et al., 1997; FORTULAN e PURQUERIO, 1998).

As cerâmicas avançadas são cada vez mais importantes nas indústrias automotivas, eletrônicas, defesa e em outros campos. Entretanto, existem vários problemas a serem resolvidos, tais como: reprodutibilidade, confiabilidade e fabricação, especialmente em produtos com superfícies complexas. Ademais apresentam alto custo de produção como um problema a ser superado. (LUKASIEWICZ, 1989 apud SATO, BESSHI e MATSUI, 1998, p. 125).

Em todas as aplicações, a microestrutura da cerâmica é decisiva no seu desempenho e depende diretamente da manufatura. A ciência da área cerâmica busca por novos métodos de processamento que permitem a produção de componentes com forma complexa e alta confiabilidade, com um mínimo de usinagem e com um baixo custo. Novas rotas para a fabricação de cerâmicas avançadas e compósitos por near-net-shape estão sendo desenvolvidas e prometem a fabricação de componentes com alta confiabilidade a custo acessível (FANTOZZI et al., 1997). Por outro lado, as cerâmicas de uso comum como os pisos, louças sanitárias e de mesa, também podem ser melhoradas em termos de resistência mecânica e confiabilidade, seja pelo refino da microestrutura como pela formulação e processamento.

O desenvolvimento de processos tecnológicos é uma exigência que pode transferir novos conhecimentos que refletem na melhora das propriedades funcionais e estruturais dos materiais e componentes cerâmicos. Novos produtos 
serão comercializáveis somente se forem eficientes em custo, ambientalmente corretos e de alta qualidade (RODEL et al., 2009).

No trabalho de Stephen (2007, apud Rodel et al., 2009) um mapa de possíveis ocorrências relativo aos processos tecnológicos foi elaborado em uma linha de tempo futurista (Figura 2.1). Este aponta contribuições e habilidades da cerâmica para resolver problemas para a maioria dos mercados de eletrônicos, geração e armazenamento de energia, meio ambiente e transporte, processamento e manufatura, saúde e questões de segurança. Destaque é dado ao fato de nearnet-shape technology ser considerada uma projeção futura.

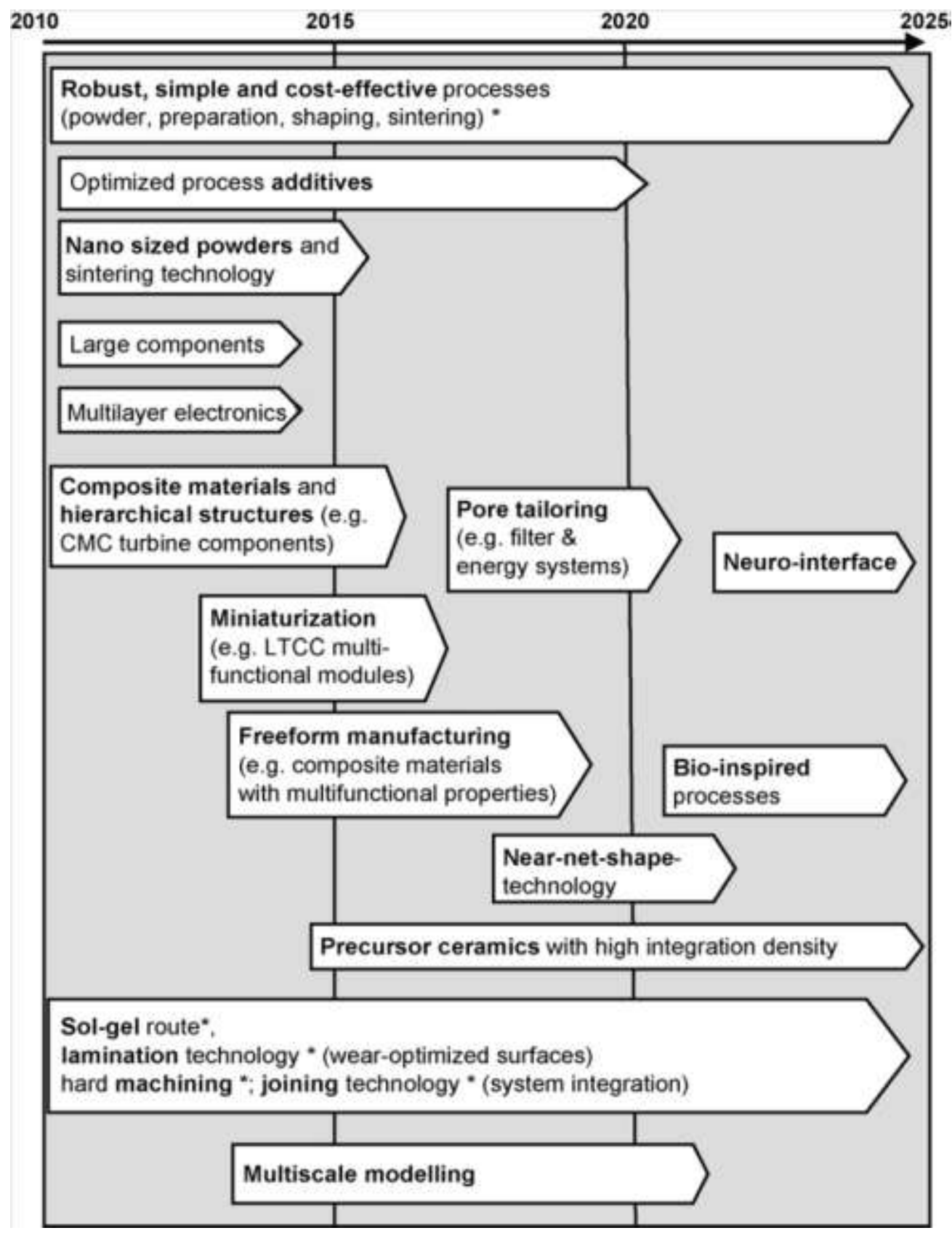

Figura 2.1 - Mapa para processos tecnológicos (RODEL et al., 2009). 
O desenvolvimento de cerâmicas com melhores propriedades irá proporcionar um aumento no número da oferta de soluções para novas aplicações. Por outro lado, existem muitas questões que devem ser tratadas em termos de necessidade no futuro, tais como: sistemas de materiais cerâmicos inovativos e multifuncionais, tecnologia de manufatura robusta e acessível, estudo de sistemas de nível de desempenho, sistemas de confiabilidade e durabilidade e custo total do ciclo de vida. Finalmente, fabricantes estão sempre procurando aumentar a competitividade e a sustentabilidade da manufatura (STEPHEN, 2007 apud RODEL et al., 2009).

Um exemplo prático de aplicação de cerâmica é em próteses dentárias. Expectativas crescentes dos pacientes em relação à aparência e confiabilidade das restaurações dentárias continuam a testar a competência e a habilidade dos dentistas. Dessa forma, tem-se a busca continuada por restaurações funcionais, totalmente de cerâmica, suficientemente resistentes e livres de metal para toda a boca (TOOD e LADDER, 1991 apud ELLAKWA et al., 2011). O desenvolvimento da tecnologia CAD/CAM (computer-aided design/computer-aided manufacturing), focada na manufatura precisa e consistente de peças cerâmicas de zircônia com elevada resistência mecânica e tenacidade é um dos motores dessa busca (REICH, PETSCHELT e LOHBAUER, 2008).

\subsection{Produção de uma peça cerâmica}

Um grande obstáculo para a total utilização do potencial da cerâmica é o desenvolvimento de um método de usinagem com custo eficaz e que, significativamente, não reduza as propriedades benéficas do material e da superfície processada. Muitas aplicações para a cerâmica, que ainda apresentam potencial de crescimento, são aquelas submetidas a alto nível de carregamento mecânico. Nesse sentido, é essencial que o processo de usinagem seja desenvolvido para não somente apresentar um método de modelagem econômico, como também, para não introduzir defeitos críticos no produto (TUERSLEY, JAWAIS e PASHBY, 1994).

A fabricação industrial de peças cerâmicas é em sua maioria obtida por meio de pó, significando que materiais em estado natural (pó finos de cerâmica) são introduzidos dentro de moldes e então compactados (LANG, 1989 apud BÖRGER, A. et al., 2002). Na compactação, a peça é deixada em seu formato final ou próxima dela, passando posteriormente pelo processo de sinterização. O principal desafio no 
processo é obter componentes com microestrutura livre de defeitos, pois poros, inclusões ou qualquer outra falta de homogeneidade da microestrutura pode causar concentração de tensão durante o carregamento do componente com risco subsequente de quebra (RAHAMAN, 2003).

A manufatura de peças com formas complexas de componentes cerâmicos por usinagem de blocos ou tarugos cerâmicos sinterizadas não é a opção preferida, devido a probabilidade de introdução de lascamentos e trincas subsuperficiais. A fabricação por near-net-shape é então a opção preferida na fabricação de peças cerâmicas, sendo geralmente baseada na técnica de processamento do pó. Pode ser realizada de duas maneiras: aproximação botton-up, tal como a moldagem direta ou por aproximação top-down, tal como a usinagem em verde (DHARA e SU, 2005).

Em métodos correntes de produção (Figura 2.2), pós são moídos e misturados, então ligantes e/ou auxiliares de sinterização podem ser adicionados para auxiliar o modelamento e a sinterização. Os pós são prensados nos formatos determinados pelo projetista para obtenção de corpos verdes, que são então, sinterizados para alcançar sua dureza e densidade final (AMERICAN MACHINIST, 1991 apud SCHELLER, 1994, p. 151).

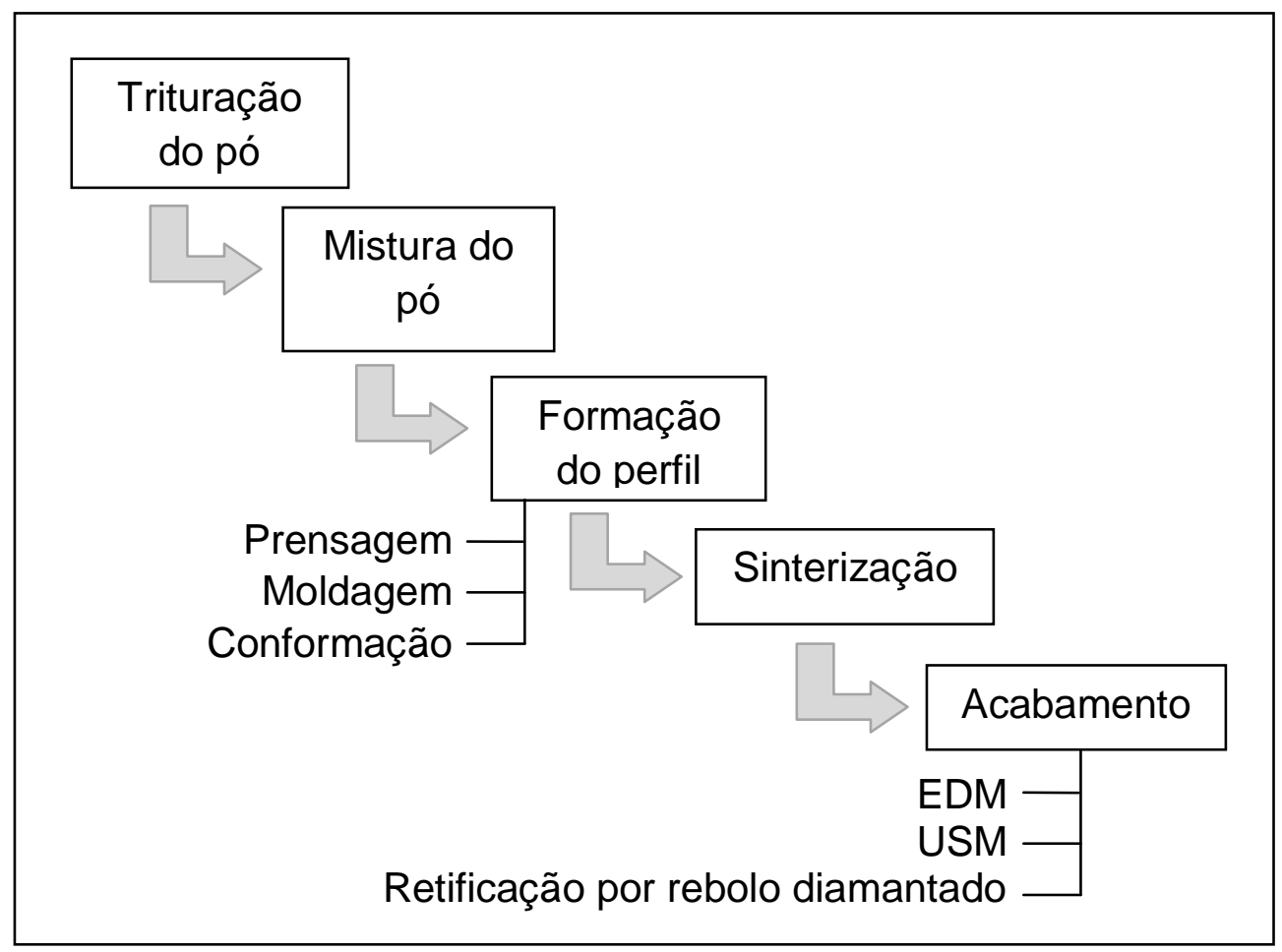

Figura 2.2 - Processo de produção corrente de componentes cerâmicos (AMERICAN MACHINIST, 1991 apud SCHELLER, 1994). 


\subsection{Compactação}

Os processos convencionais de moldagem para materiais cerâmicos podem ser agrupados em: prensagem (prensagem a seco, prensagem isostática); conformação coloidal (colagem de barbotina, slip casting) e moldagem plástica (extrusão e moldagem por injeção). Para o sucesso da prensagem a seco, um pó fluído é necessário para preencher a cavidade do molde uniformemente. Para esse propósito, geralmente, o pó cerâmico em estado natural é disperso em água contendo aditivos poliméricos (ligante, defloculante e lubrificante) e a mistura (s/urry) passa pelo processo de secagem (spray-drier) para formar grânulos fluíveis (LUKASIEWICZ, 1989 apud SATO, BESSHI e MATSUI, 1998).

A secagem por pulverização (spray-drying) é um método largamente utilizado na indústria (por ser contínuo, econômico e reprodutível) para a produção de grânulos com densidade e tamanho controlados, de boa fluidez e capacidade de compactação. Essa secagem consiste na pulverização de uma suspensão, sob a forma de gotículas, em uma corrente de ar ou gás inerte quente, que permite produzir grânulos praticamente esféricos (diâmetro de 50 a $500 \mu \mathrm{m}$ ) e com superfície externa relativamente lisa (Figura 2.3) (BOCH e NIÈPCE, 2007).

A formação de gotículas é geralmente realizada por dois principais métodos: a centrifugação, usando turbina de alta velocidade na parte superior (Figura 2.4 (a)), ou por spray da suspensão injetada sob pressão, de baixo para cima através de um bico injetor (Figura 2.4 (b)).

A compactação em molde de pó cerâmico seco é a técnica mais empregada na manufatura cerâmica e na tecnologia do pó, sendo fundamental na produção de componentes cerâmicos de alta qualidade. $O$ objetivo da técnica da prensagem a seco é a obtenção de produtos com densidade em verde uniforme, alto fator de compactação, livres de defeitos e em alta escala de produção (LEWIS, 1996 apud KUMAR et al., 2000).

Dentre os processos de prensagem, destaque é dado à prensagem isostática a frio que é usada para compactar blanks em verde com elevada densificação e homogeneidade, em geral o formato final é obtido pela usinagem em verde pósprensagem. (LINDQVIST e CARLSTROM, 2002).

A prensagem isostática pode ser dividida em dois tipos: prensagem de molde molhado (wet mold pressing ou wet-bag), esquematizado na Figura 2.5 (a); e 
prensagem de molde seco (dry mold pressing ou dry-bag), esquematizado na Figura 2.5 (b). No wet-bag, o enchimento do molde é realizado em um estágio anterior e posteriormente prensado no interior da câmara da prensa com o auxílio de um fluido hidráulico. Já na prensagem dry-bag, o enchimento do molde ocorre diretamente na prensa, que aplica pressão radialmente à peça através de um fluido entre a parede deformável do molde e a carcaça rígida da prensa. O processo permite maior produção do que o wet-bag e é utilizado para manufaturar pequenas peças $(\mathrm{BOCH} e$ NIÈPCE, 2007; REED, 1995).

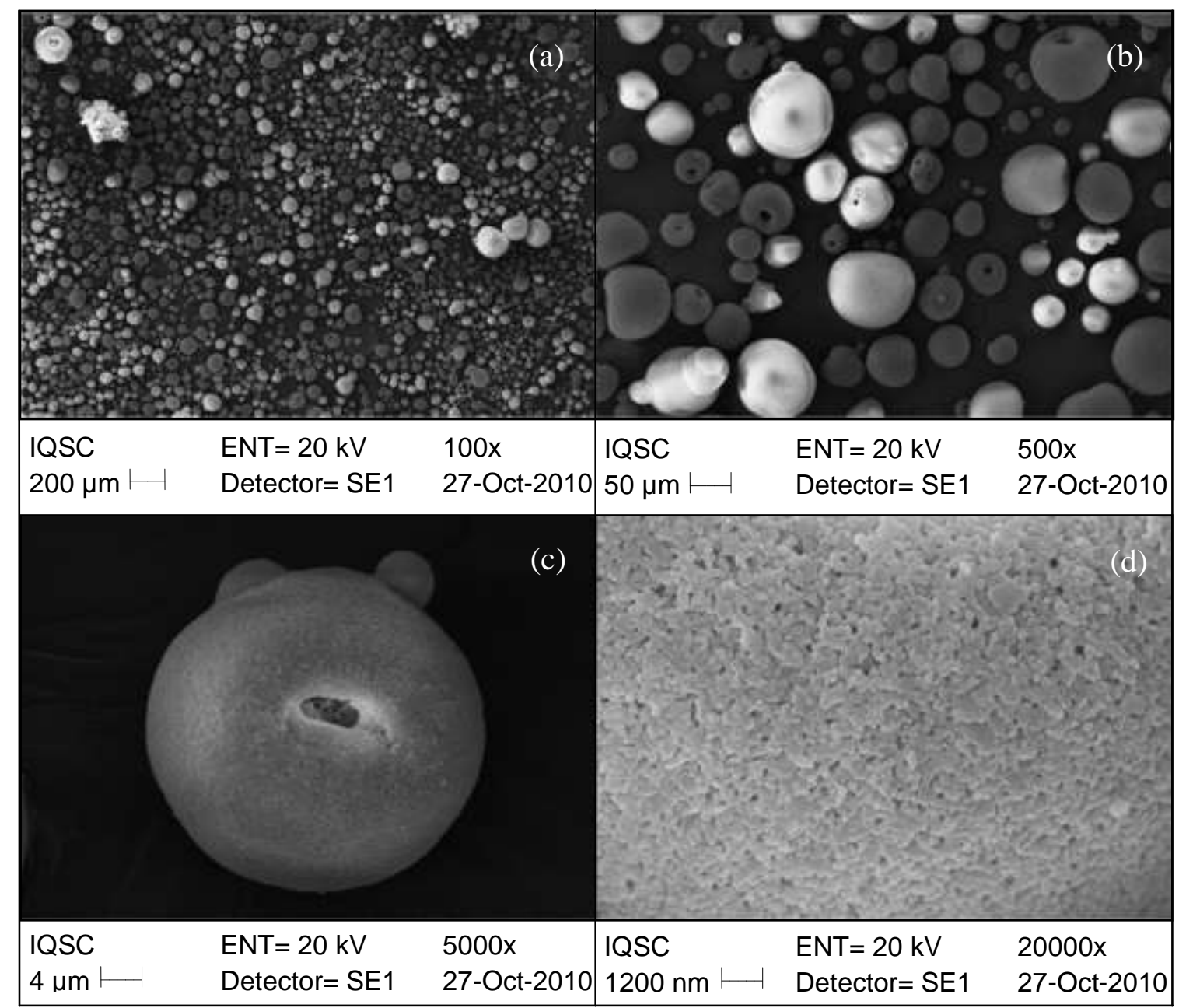

Figura 2.3 - Grãos de alumina obtidos por secagem por pulverização em diferentes magnificações (a, b, c e d), é possível, na superfície de um grânulo, obervar as partículas cerâmicas (BUKVIC, 2011).

No trabalho de Desfontaines et al. (2005), foi utilizada a técnica de microscopia eletrônica de varredura (MEV) para identificar a melhor pressão de compactação a ser utilizada no processo. A Figura 2.6 mostra as imagens do pó 
cerâmico, produzido por spray-drier, conformado por prensagem uniaxial de dupla ação a diferentes pressões no estado verde. Nessas imagens é possível observar uma maior união dos grânulos em relação ao aumento da pressão.

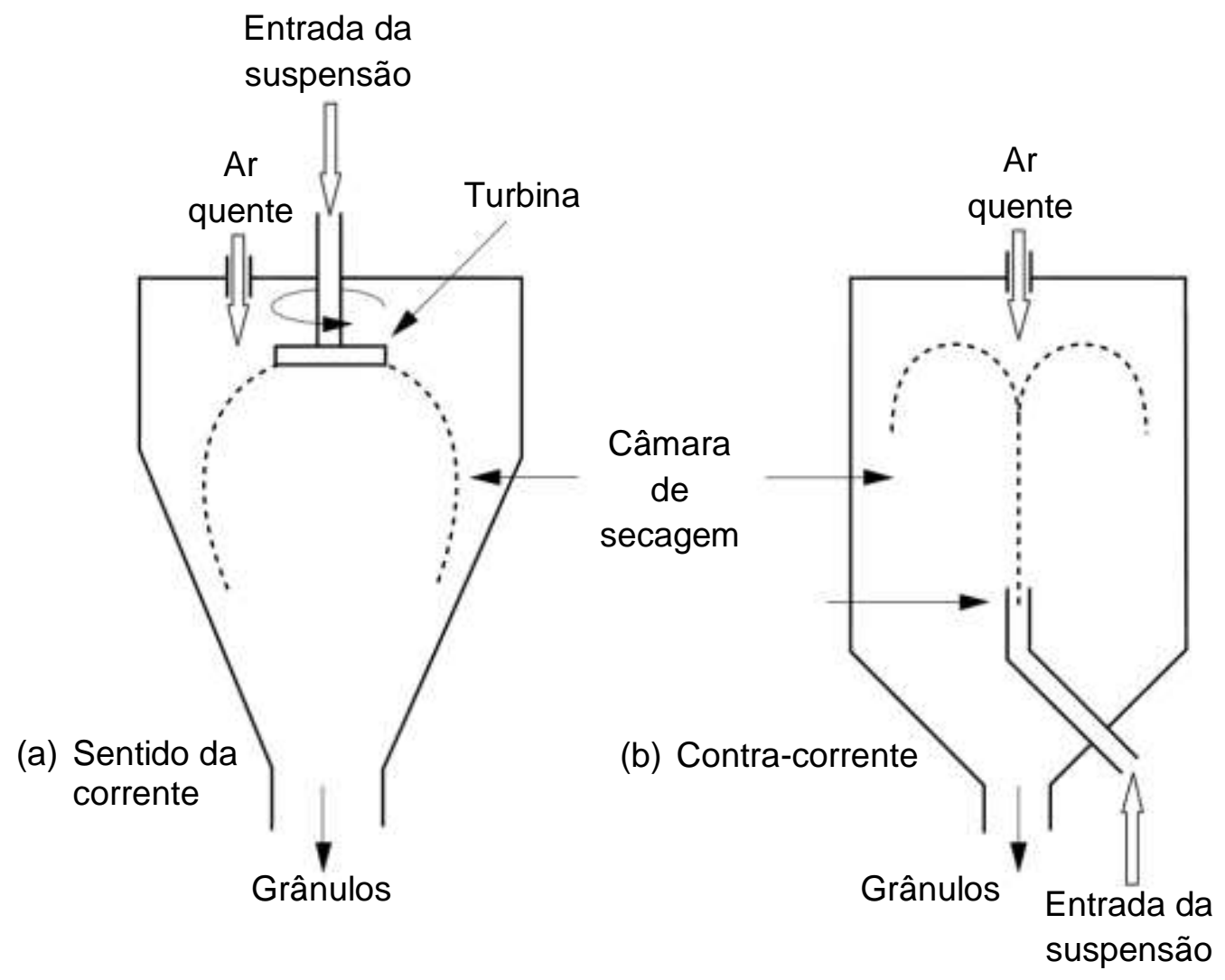

Figura 2.4 - Representação esquemática dos processos de secagem por pulverização, (a) sentido da corrente e (b) contra-corrente (BOCH e NIËPCE, 2007, adaptado).

(a) Molde molhado

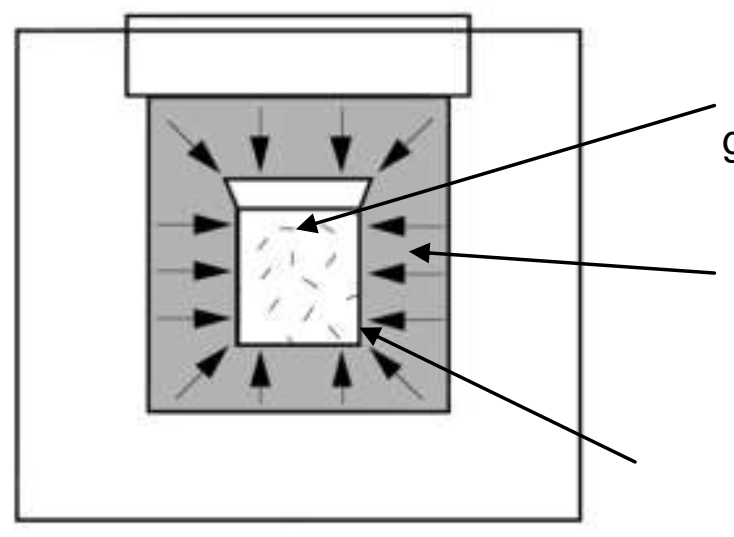

Pó

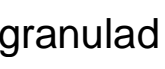

Fluido

Molde (b) Molde seco [Pistão

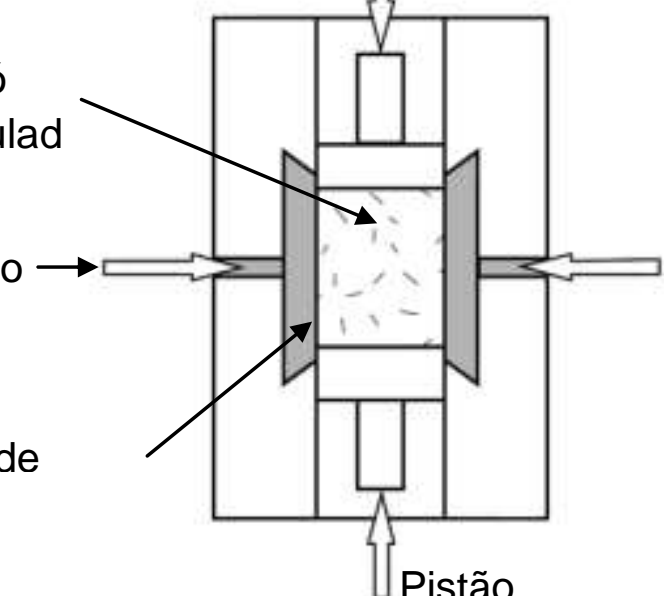

Figura 2.5 - Princípios da prensagem isostática (a) de molde molhado e (b) molde seco (BOCH e NIĖPCE, 2007, adaptado). 


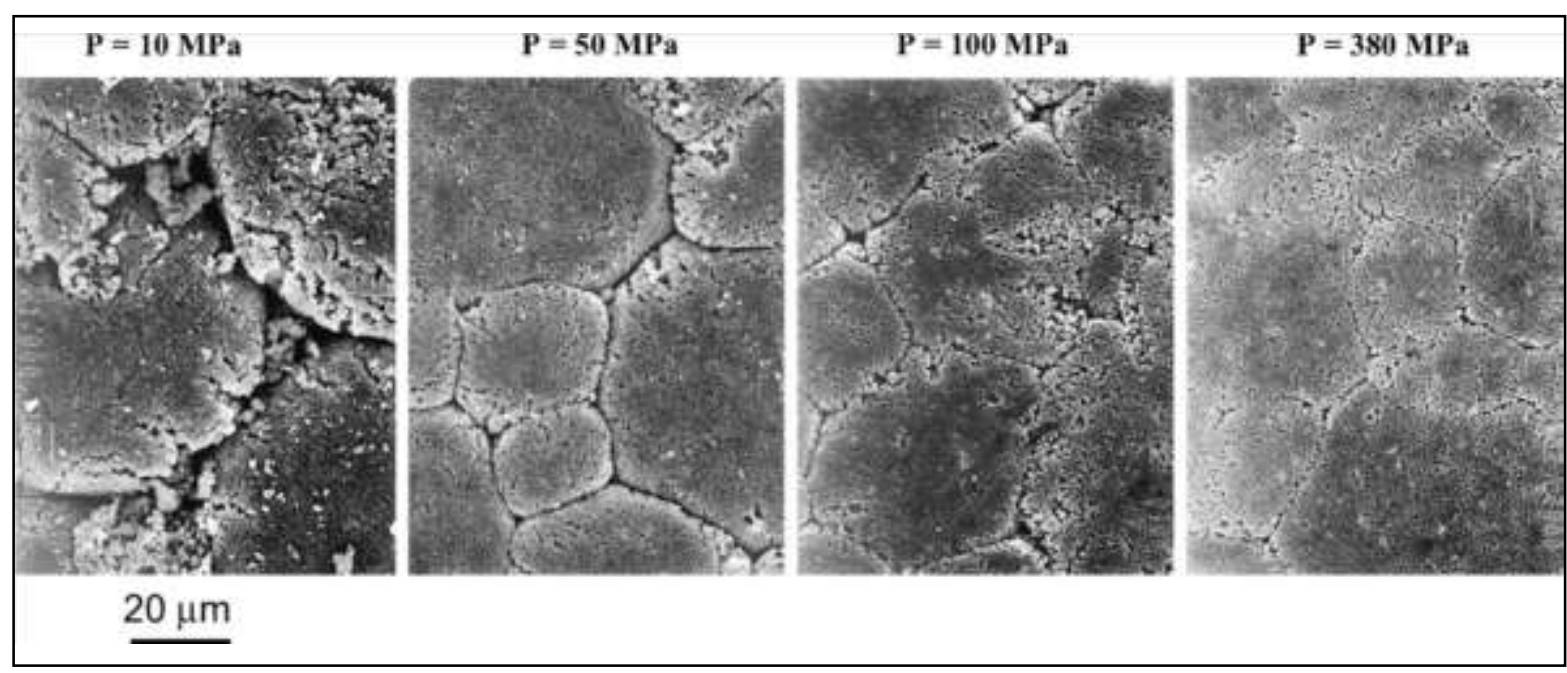

Figura 2.6 - Superfícies das peças obtidas por diferentes pressões de compactação (DESFONTAINES et al., 2005).

Neste mesmo trabalho, foi realizado ensaio mecânico nas peças para analisar o tipo de mecanismo de fratura em relação ao tipo de pressão de prensagem e ao tipo de composição empregado no preparo do pó. Nas imagens obtidas por MEV das Figuras 2.7 a 2.9, foi possível observar na composição $A$ o modo de fratura predominantemente intergranular, já a composição $B$ apresentou modo de fratura principalmente transgranular e a composição $C$ apresentou o modo de fratura totalmente transgranular (DESFONTAINES et al., 2005).

Alta pressão de compactação aumenta a resistência mecânica do compactado, proporcionando melhor fixação, mas decrescendo o comprimento de origem dos defeitos críticos e por isso causando deterioração na retenção de borda. Uma pressão intermediária deve ser selecionada para obter resistência à fixação e usinabilidade, já uma baixa pressão de compactação pode ser utilizada em situações onde a resistência mecânica após a sinterização é menos importante comparada com a qualidade de borda, nesse caso uma pré-sinterização pode ser utilizada para aumentar a resistência sem reduzir a retenção de borda (SONG e EVANS, 1997).

Problemas relacionados a prensagem isostática wet-bag podem ser relatados antes, durante e após a prensagem. Antes da prensagem podem ser citados problemas como: falha de preenchimento do molde, gerando peças defeituosas, e mau fechamento do molde, permitindo infiltração de fluido da prensa na peça. Problemas que podem ser relatos durante a prensagem são: parte deformável do molde com perfuração, causado por excesso de uso ou dano que leva a infiltração 
de fluido da prensa na peça, e falha de vedação da tampa, devido ao desgaste do molde que leva a infiltração de fluido da prensa na peça. Após a prensagem podem ser relatados problemas como: a quebra da borda da peça ou até mesmo a quebra da mesma, ambas as situações podem ocorrer durante a remoção da peça do molde ou até mesmo durante a despressurização da prensa, causado pelo retorno da parte deformável do molde ao seu tamanho original.

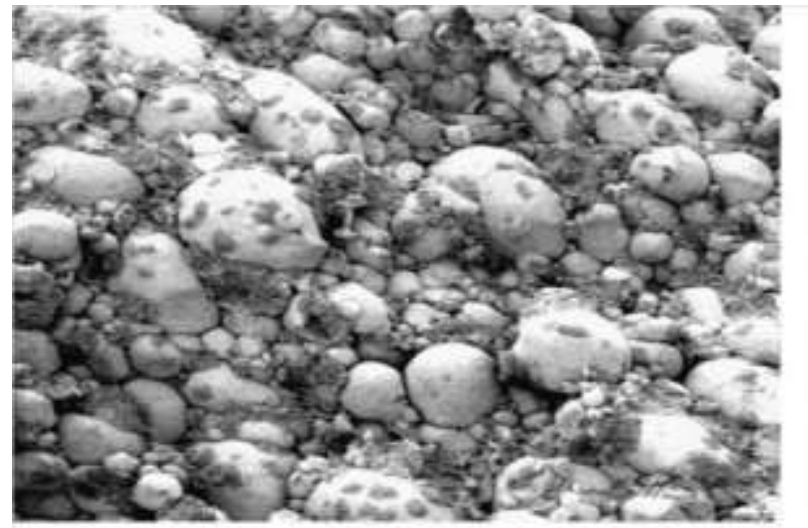

$10 \mathrm{MPa}$
$100 \mu \mathrm{m}$

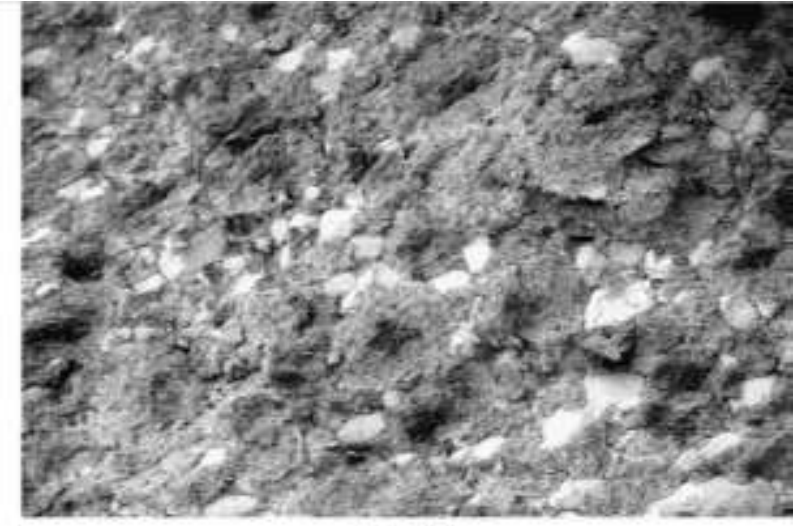

$100 \mathrm{MPa}$

Figura 2.7 - Fratura das peças em verde A prensadas a 10 e $100 \mathrm{MPa}$ (DESFONTAINES et al., 2005).

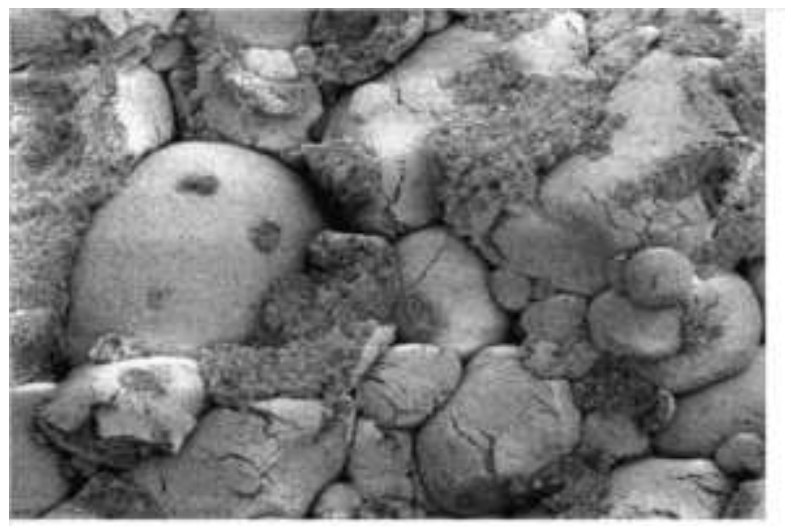

$10 \mathrm{MPa}$

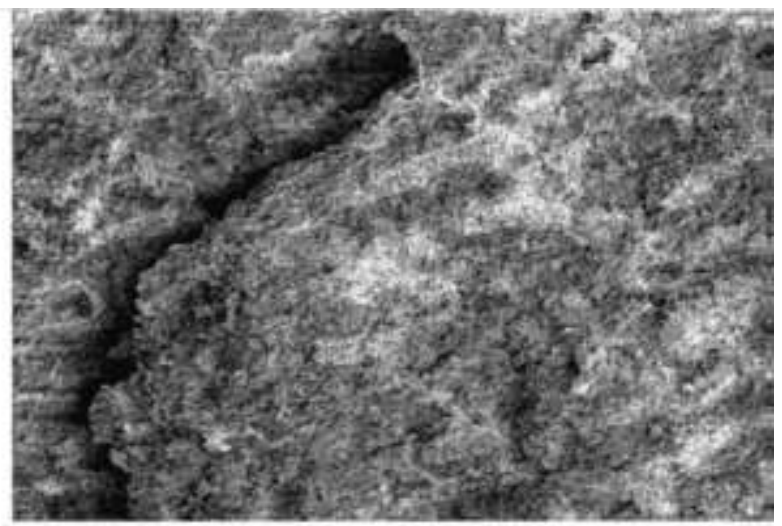

$100 \mathrm{MPa}$

Figura 2.8 - Fratura das peças em verde B prensadas a 10 e $100 \mathrm{MPa}$ (DESFONTAINES et al., 2005).

A compactação pode causar, ainda, gradiente de densidade na peça (regiões de maior e menor densidade), causada por uma má distribuição da pressão de compactação durante a prensagem. Esse efeito é comumente observado na prensagem uniaxial, pois é um processo que utiliza um molde rígido com duas 
punções que recebem a força da prensa (podendo as duas se mover, chamado de dupla ação; ou apenas uma se mover, chamado de simples ação). Processo que, por princípio, causa variação da pressão de prensagem devido ao atrito do pó com o molde (BUKVIC, 2011).

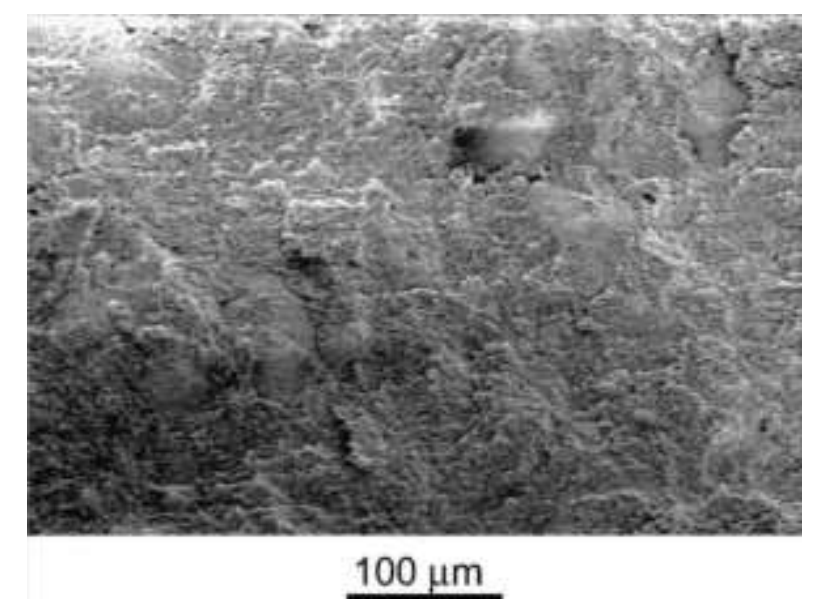

Figura 2.9 - Fratura das peças em verde $\mathrm{C}$ prensadas a $10 \mathrm{MPa}$ (DESFONTAINES et al., 2005).

O gradiente de densidade causa uma distorção dimensional da peça, pois regiões de menor densidade contraem mais no processo de sinterização, enquanto que regiões de maior densidade contraem menos (BUKVIC, 2011).

A prensagem isostática promove uma distribuição uniforme da pressão sobre o pó a ser compactado. Dessa forma, nenhum ou quase nenhum gradiente de densidade é observado na peça, sendo assim desprezado o efeito da distorção dimensional.

\subsection{Sinterização}

Sinterização é a consolidação, sob efeito da temperatura, de um material granular não coeso (pó), por meio da soldagem dessas partículas umas com as outras para criar um sólido coeso mecanicamente, geralmente um em policristal. $O$ termo sinterização abrange quatro fenômenos (consolidação, densificação, crescimento de grão e reações físico-químicas) que acontecem simultaneamente e muitas vezes competem entre si (BOCH e NIÈPCE, 2007).

Como exemplo, pode ser citado o caso da sinterização de um material puro de uma única fase, como a alumina. O material é aquecido na faixa de 0,5 a 0,75 da 
temperatura de fusão. O pó não funde, em vez disso, a união das partículas e a redução da porosidade, conhecida como densificação, ocorre pela difusão atômica no estado sólido. No processo de densificação átomos são difundidos da superfície da partícula para a região do contorno do grão, formando e desenvolvendo um pescoço na região de contato, onde antes era vazio, levando a retração. Normalmente, tal sinterização é conhecida como sinterização em estado sólido (RAHMAN, 2005).

Os caminhos de difusão para a densificação e crescimento de grão são mostrados na Figura 2.10 para uma situação idealizada de contato entre três partículas esféricas.

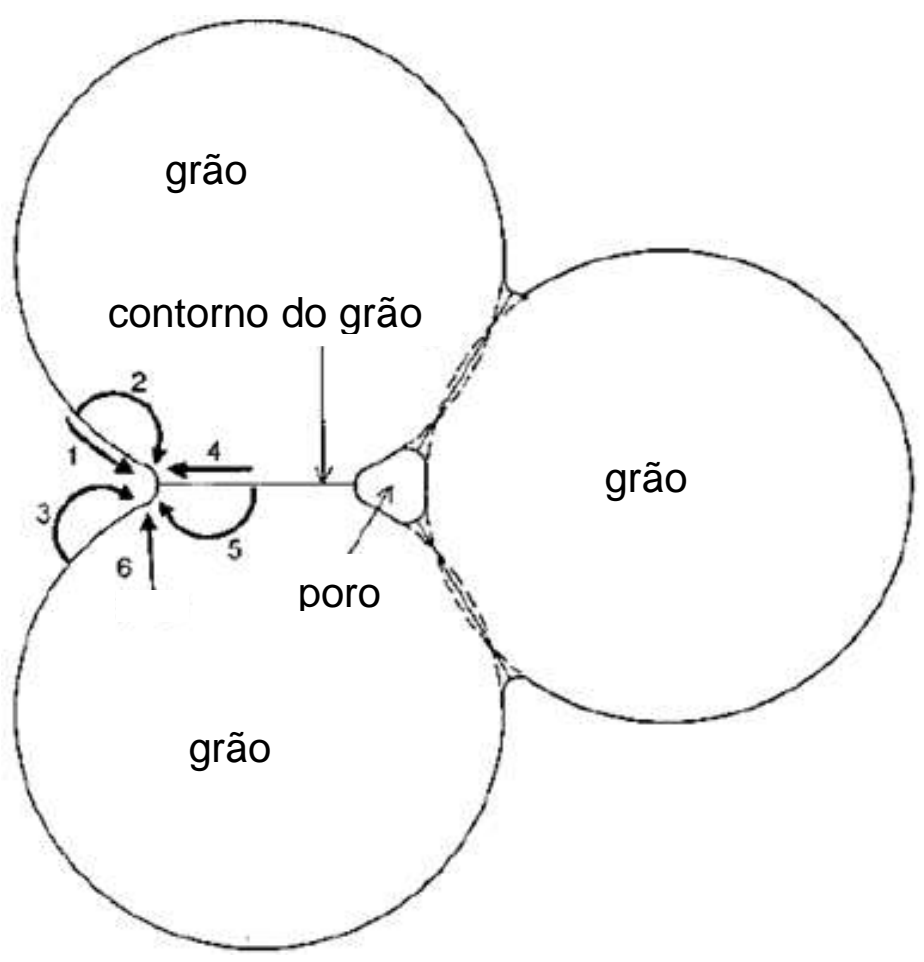

Figura 2.10 - Seis diferentes mecanismos podem contribuir para a sinterização de uma massa consolidada de partículas cristalinas: (1) difusão superficial, (2) difusão de rede da superfície, (3) transporte de vapor, (4) difusão no contorno de grão, (5) difusão de rede na fronteira do grão e (6) fluxo plástico. Somente mecanismos 1,2 e 3 levam a densificação, mas todos causam o crescimento do pescoço e, portanto, influenciam na velocidade de densificação (RAHMAN, 2005, adaptado). 


\subsection{Ligante}

O ligante é o aditivo mais importante na prensagem, também o mais importante na granulação de cerâmicas por spray-drier. Esse tem grande influência nas propriedades dos grânulos cerâmicos, tais como densidade aparente, taxa de fluidez e comportamento de compactação. É tipicamente um polímero de cadeia longa que exercem a função primária de promover a resistência mecânica em verde do corpo cerâmico, formando pontes entre as partículas. Um bom ligante deve promover resistência em verde com a adição em menor concentração possível na barbotina cerâmica. Em alguns métodos de conformação ele também promove a plasticidade que auxilia o processo de conformação (WU et al., 1997 apud KUMAR, 2000; LUKASIEWIES e REED, 1978 apud KUMAR, 2000; REED e RUNK, 1976 apud KUMAR, 2000).

Os ligantes podem ser de dois tipos: orgânicos e inorgânicos. O orgânico é o mais utilizado (VANDEPERRE et at., 1978 apud KUMAR et al., 2000), alguns são solúveis em água, enquanto outros são solúveis em líquidos orgânicos (RAHAMAN, 2003), que incluem os vinis, acrílicos e óxidos etilenos (glicóis). O ligante orgânico influencia as propriedades das cerâmicas obtidas pelo processo de compactação, uma vez que ele governa a propriedade mecânica do grânulo, controlando o comportamento da compactação e a estrutura resultante da peça em verde (REED, 1995). A adição de ligantes orgânicos no pó cerâmico spray-dried aumenta a resistência mecânica do pó e do corpo prensado (BAKLOUTI, CHARTIER e BAUMARD, 1999 apud TAKTAK, BAKLOUTI e BOUAZIZ, 2011).

Os ligantes ainda podem ser subdivididos em termoplásticos e termofixos. Como exemplos de ligantes termoplásticos temos o poli (álcool vinílico) (PVAl), poli (butiral vinílico) (PVB) e os acrílicos. Exemplo de ligante termofixo é a resina epóxi. O ligante termoplástico pode fundir durante um processo de usinagem induzindo o aumento da força de usinagem e ao empastamento da ferramenta, o mesmo já não ocorre com o ligante termofixo que, devido ao processo de cura trifuncional, não permite mais a ocorrência de fusão cristalina (WU e MCANANY, 1995 apud LEE, 2003). 
No trabalho de Ander, Lehmann e Ziegler (1997), foram apresentados algumas necessidades que o ligante deve proporcionar a uma peça compactada:

- alta resistência mecânica da peça em verde;

- reduzida fragilidade;

- alta rigidez da peça em verde;

- possibilidade de usinagem em verde;

- baixa quantidade de adição.

No trabalho de Ander, Lehmann e Ziegler (1997), foi realizado um estudo analisando o efeito do peso molecular da cadeia molecular na resistência mecânica em verde, por meio do ensaio de flexão 4 pontos, Figura 2.11, sendo observados diferentes resistências e deformações para as diferentes cadeias.

Na prensagem a seco de cerâmicas, os ligantes mais utilizados são o PVAl e o poli (glicol etileno) (PEG). PVAI produz alta resistência mecânica em verde, por outro lado, PEG produz alta densidade em verde (NIES e MESSING, 1984 apud KUMAR et al., 2000; DIMILIA e REED, 1983 apud KUMAR et al., 2000).

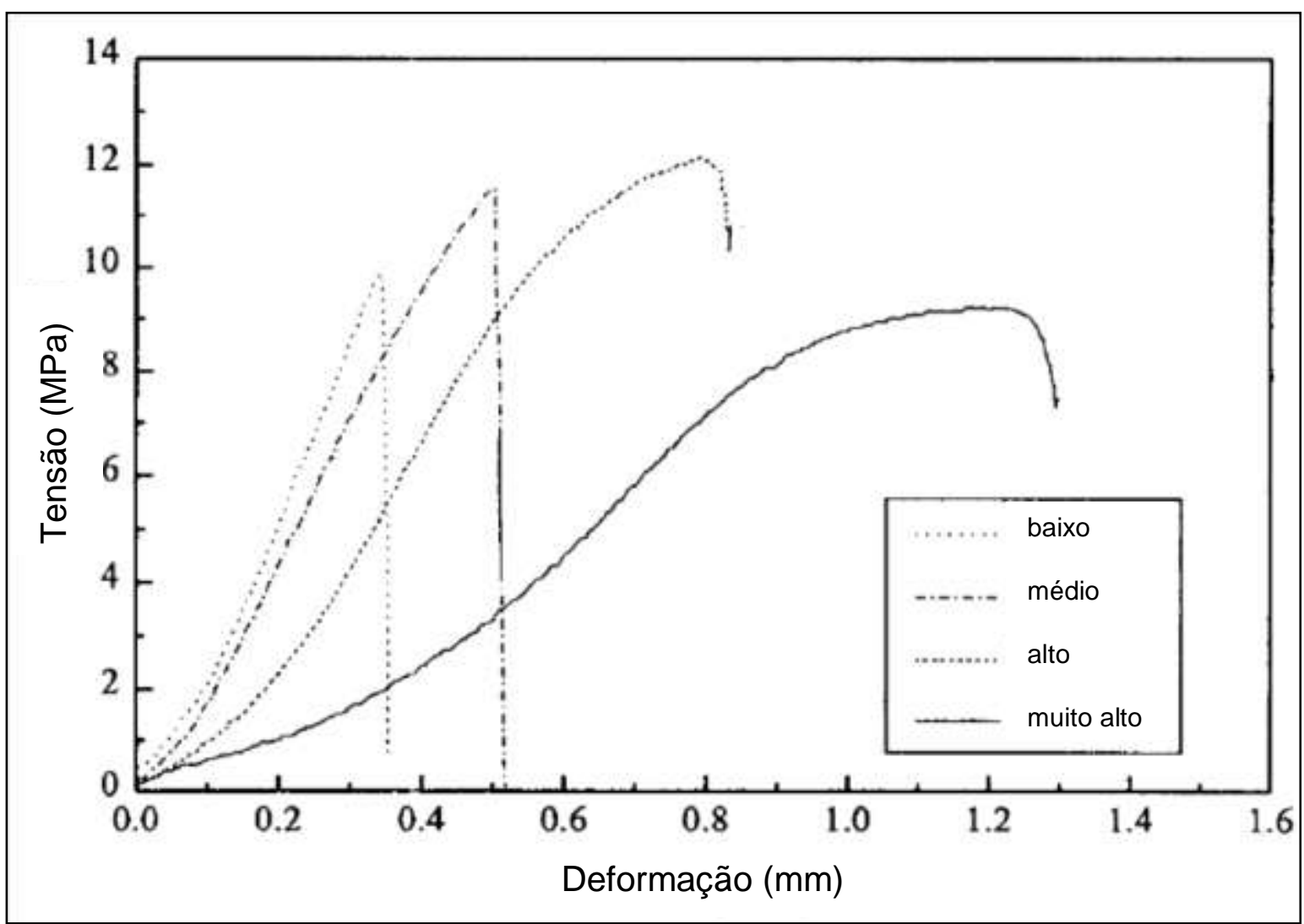

Figura 2.11 - Diagrama tensão deformação, demonstrando o efeito do peso molecular do ligante (ANDER, LEHMANN e ZIEGLER, 1997). 
O PVAl, além disso, é uma ferramenta da formulação altamente efetiva e versátil devido a sua estabilidade em solução, sua compatibilidade com muitos ingredientes das formulações mais comuns e sua alta disponibilidade (BASSNER e KLINGENBERG, 1998 apud KUMAR et al., 2000).

Normalmente, PVAl e PEG são usados como ligantes, mas sofrem por suas característica hidrofílicas. Por outro lado, ligantes acrílicos possuem natureza hidrofóbica. Os ligantes copolímeros acrílicos podem ser obtidos pelas técnicas de solução, suspensão e emulsão polimerizável (BASSNER e KLINGENBERG, 1998 apud KUMAR et al., 2000).

Os ligantes termoplásticos são muito higroscópicos, o que, devido a umidade, acaba alterando outra característica do ligante: a sua temperatura de transição vítrea (Tg). As características mecânicas das peças compactadas produzidas com esse tipo de ligante requerem teste de controle e condição de armazenamento controlado (DESFONTAINES, GONON e FANTOZZI, 2005).

O Tg de um ligante polimérico é um dos mais importantes parâmetros para controlar o desempenho de um ligante durante a prensagem a seco, além de também afetar a densidade em verde das peças cerâmicas compactadas a seco (NIES e MESSING, 1984 apud KUMAR et al., 2000; DIMILIA e REED, 1983 apud KUMAR et al., 2000).

Densidade em verde é um dos mais importantes parâmetros na formação dos artigos de cerâmicas. Para um dado pó cerâmico, alta densidade em verde indica um melhor empacotamento resultando em menor contração durante a sinterização. No trabalho de LANNUTTI et al. (1997 apud KUMAR et al., 2000) para todos os ligantes acrílicos estudados, a densidade em verde diminui linearmente com 0 aumento da quantidade de ligante misturado ao pó cerâmico. O volume ocupado pela fase do ligante causa a separação das partículas, causando a diminuição da densidade observada. Otimização da carga de ligante no material cerâmico é necessária para a obtenção de alta densidade e um compactado mais uniforme.

Assim, em geral, a densidade em verde deve diminuir com a adição de ligante, mas ligantes de alto desempenho causam um impacto menos negativo na densidade em verde (WU et al., 1997 apud KUMAR et al., 2000).

No trabalho de TAKTAK, BAKLOUTI e BOUAZIZ (2011) foi analisado o efeito da quantidade de ligante PVAI, na prensagem a seco de grânulos de alumina obtidos no spray-drier. Pela Tabela 2.1 pode ser observado que o ligante tem efeito 
considerável na densificação da cerâmica compactada. Quando se compara a peça sem ligante e com ligante, este foi o responsável pelo aumento da densidade relativa da peça. Observou-se, também, que com o aumento da quantidade de ligante ocorreu uma dificuldade de compactação, causando menor densidade relativa, devido a um endurecimento dos grânulos.

A tensão de ruptura de uma peça em verde de alumina é geralmente abaixo de $10 \mathrm{MPa}$, e as outras características da peça em verde são largamente dependentes das propriedades do ligante polimérico (WU e MCANANY, 1995 apud LEE et al., 2003).

Tabela 2.1 - Propriedades de diferentes misturas de alumina compactadas sinterizadas a $1700^{\circ} \mathrm{C}$ (TAKTAK, BAKLOUTI e BOUAZIZ, 2011).

\begin{tabular}{|c|c|c|}
\hline Ligante PVAl (\%peso) & $\begin{array}{c}\text { Densidade relativa } \\
(\%)\end{array}$ & $\begin{array}{c}\text { Volume da contração } \\
(\%)\end{array}$ \\
\hline 0 & 82 & 32 \\
\hline 1 & 94 & 40 \\
\hline 3 & 84 & 36 \\
\hline
\end{tabular}

Se a resistência mecânica em verde é menor do que $2 \mathrm{MPa}$, há a tendência de ocorrer alta taxa de falha (quebra e lascamentos) com o subsequente aumento de descarte. Por outro lado, se a resistência em verde é muito alta, problemas como baixa vida de ferramentas, vibração, deflecção e fratura catastrófica podem ocorrer. Em alguns casos um plastificante pode ser adicionado à formulação do ligante para evitar esses problemas (SHEPPARD, 1999).

Ligantes PVAl e PEG permitem resistência mecânica em verde dentro de 1 $\mathrm{MPa}$, uma vez que eles não têm uma forte interação entre suas cadeias poliméricas. Já o ligante acrílico consiste em grupos ácidos carboxílicos que interagem fortemente com o pó cerâmico, e a ligação entre cadeias de hidrogênio também resultam em forte interação entre as cadeias poliméricas. Tal ligante tem sido desenvolvido pela Rohn and Haas Co. para a aplicação em usinagem em verde, permitindo resistência em verde maiores que 6,5 MPa (SHEPPARD, 1999).

A resistência em verde de um material cerâmico aumenta linearmente com o aumento na quantidade de ligante adicionado a base cerâmica (KUMAR et al., 2000), desempenhando, dessa forma, um papel importante na usinabilidade. A aplicação do ligante nas formulações cerâmicas deve ser planejada, para evitar o 
lascamento e a quebra da peça durante a usinagem e o manuseio e, ao mesmo tempo, permitir uma rápida remoção do material durante a operação de usinagem (SHEPPARD, 1999).

A resistência em verde é, também, dependente da umidade, devido ao fato da água reduzir as interações das cadeias poliméricas diminuindo a resistência em verde e causar aumento da densidade relativa do pó prejudicando a compactação. Secar a peça após a compactação também pode aumentar a resistência em verde (SHEPPARD, 1999).

Durante a prensagem de uma peça, são introduzidas tensões internas no material, que podem ser removidas por tratamento térmico. O tratamento promove a redução das tensões resultando em maior resistência em verde. É também associado com uma reorganização das partículas e do ligante em uma escala microscópica. Esta reorganização é equivalente a uma homogeneização da peça em verde, que resulta em menor profundidade de lascamento da borda, porque há muito menos irregularidades locais na resistência em verde. Assim, a própria resistência em verde não é responsável pela qualidade das estruturas, mas sim a homogeneidade do material e as interações entre partículas a uma escala microscópica (PFRENGLE et al., 2009).

\subsection{Usinagem da cerâmica}

A usinagem da cerâmica tem sido amplamente utilizada na manufatura da cerâmica avançada. Processos de usinagem podem ser usados para fazer peças cerâmicas com alta precisão, com formas complexas que são inacessíveis por meio dos métodos normais de conformação. Apesar de suas excelentes resistências mecânica em alta temperatura, suas resistências à oxidação e suas estabilidade química, a aplicação de cerâmicas estruturais para alta temperatura continuam a ser aplicadas comumente em situações limitadas ao carregamento compressivo e de baixo impacto por conta de sua natureza frágil (SHEPPARD, 1992).

A resistência das cerâmicas usinadas é influenciada pelas trincas residuais deixadas na superfície acabada (NISHI e SUGITA, 1994 apud BESSHI, SATO e TSUTSUI, 1999).

A usinagem cerâmica pode ser classificada em duas categorias, com a peça em seu estado verde ou sinterizado. O processo de retificação, com a ferramenta 
rebolo, é geralmente utilizado na usinagem de peças cerâmicas sinterizadas. Mas os abrasivos utilizados para produzir esses rebolos devem ser mais duros que as cerâmicas a serem usinadas. Abrasivos típicos usados são o diamante e o nitreto de boro cúbico (CBN). O alto custo dos rebolos produzidos com esses abrasivos, associado a baixa taxa de remoção na usinagem do material duro e frágil, limitam a produção em massa de peças cerâmicas após a sua sinterização. Por outro lado, a usinagem em verde de peças prensadas é atualmente usada para dar forma a peças pequenas e simétricas, tais como velas automotivas (SHEPPARD, 1992).

O trabalho de McKeown e Shore (apud Tuersley, Jawaid e Pashby,1994) sugere uma série de características para que se permita a retificação de cerâmicas sinterizadas:

- A retificadora deve apresentar alta rigidez entre a ferramenta e a peça (>180 $\mathrm{N} / \mathrm{mm}$ ) para evitar a deflexão da máquina por conta das forças de usinagem.

- A máquina deve ser capaz de repetir seus movimentos com posicionamentos precisos superiores a $0,1 \mathrm{~mm}$.

- A máquina deve ter alto amortecimento interno.

- A especificação do rebolo deve ser otimizada.

- Preparativo técnico de precisão do rebolo deve ser utilizado.

- Controle da temperatura e filtragem do fluído de corte deve ser empregado $\left(0,1^{\circ} \mathrm{C}\right.$ e $\left.0,1 \mathrm{~mm}\right)$.

O processo de retificação pode introduzir defeitos, trincas superficiais e subsuperficiais, que causam perdas de resistência mecânica do material, frequentemente em uma escala extremamente difícil de ser detectada (MCKEOWN e SHORE apud TUERSLEY, JAWAID e PASHBY, 1994).

Estudos experimentais mostraram que jaquetas dentárias feitas de zircônia tetragonal policristalina estabilizada com ytria (Y-TZP) sinterizada, podem ser usinadas usando um sistema de CAD/CAM com uma retificadora de alta rigidez. Mas os resultados indicaram danos na microestrutura desse material após o processo de retificação. Mesmo com a variação ampla dos parâmetros da usinagem não houve solução para a eliminação dos danos, como o observado na Figura 2.12. Uma alternativa seria a usinagem da cerâmica pré sinterizada, que é um procedimento de usinagem diferente da retificação. Essa também pode ser aplicada por CAD/CAM na fabricação de coroas e pontes dentárias, com o aumento da resistência mecânica e da confiabilidade das peças (LUTHARDT et al., 2004). 


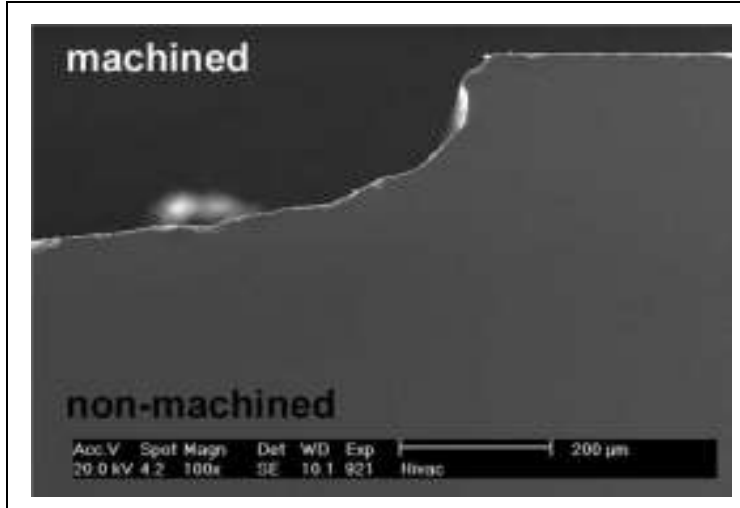

(a)

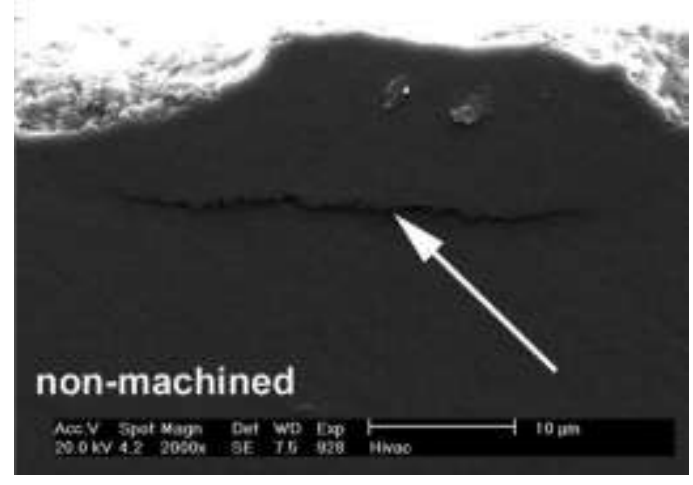

(b)

Figura 2.12 - Indução de microtrincas pela retificação, (a) magnitude de 100X e (b) magnitude de 2000X (LUTHARDT et al., 2004).

No trabalho de Filser, Kocher e Gayckler (2003), um processo descrito como direct ceramic machining (DCM), o qual promove a usinagem de compactados cerâmicos pré sinterizados, tem sido avaliado para aplicações em componentes técnicos e dentários, ver Figura 2.13. Na aplicação dentária, as dimensões especificadas foram atingidas, porém as lacunas marginais ficaram maiores do que o especificado, o que sugere melhoria. Contudo, o componente obtido por DCM não necessita de uma usinagem posterior, concluindo que o processo proporciona alta precisão para uma ampla quantidade de componentes cerâmicos com baixo tempo de fabricação.

Uma atrativa forma de usinar peças cerâmicas é usiná-las antes da sinterização total, ou seja, usar blanks parcialmente sinterizados (HALCOMB e REY, 1982 apud KOH e HALLORAN, 2004) ou em verde (WU e MACANANY, 1995 apud KOH e HALLORAN, 2004; SONG e EVANS, 1997; KUMAR et al., 2000). 


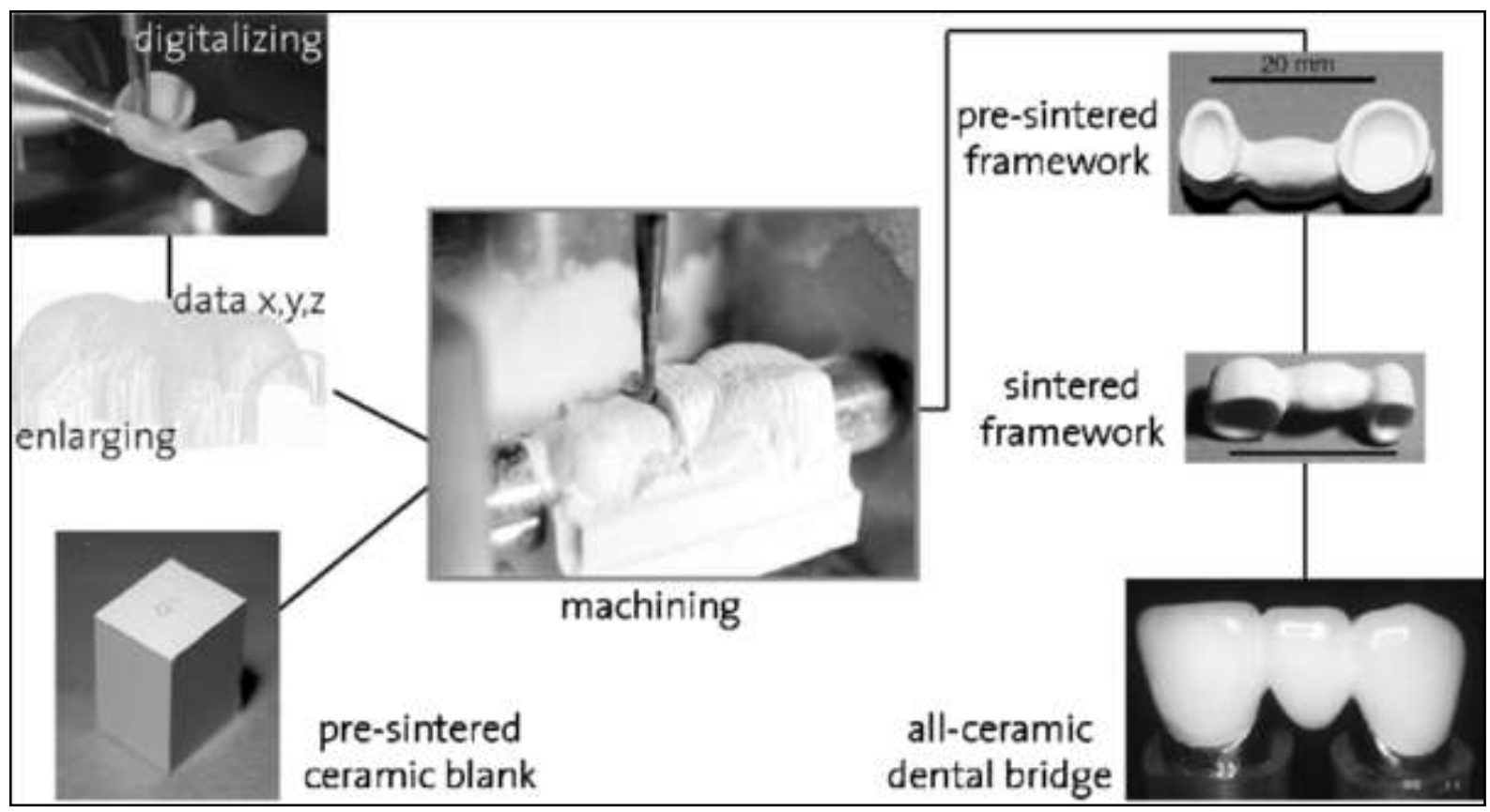

Figura 2.13 - O DCM na rápida manufatura de componentes técnicos (FILSER, KOCHER e GAYCKLER, 2003).

\subsection{Custos da usinagem}

O custo de usinagem é um dos mais importantes fatores que determinam se um processo de usinagem é viável ou inviável (ZHANG et al., 2004).

Devido à alta dureza das cerâmicas avançadas, é quase sempre muito custosa a fabricação de peças pela usinagem no estado sinterizado. Dessa forma, um foco contínuo é o desenvolvimento da fabricação pelo processo near-net-shape, que pode produzir componentes com forma complexa com um mínimo de usinagem em virtude da otimização e controle de cada passo do processo de fabricação. Além disso, com o objetivo de minimizar o número e o tamanho dos defeitos microestruturais (RAHAMAN, 1995).

A usinagem de cerâmicas sinterizadas consome muito tempo e energia, podendo representar até $80 \%$ do custo da produção de uma peça cerâmica. Uma possibilidade é a utilização da técnica da usinagem em verde, sendo esta muito mais econômica e rápida, podendo ser realizada utilizando técnicas e ferramentas aplicadas aos metais. O seu maior problema é a obtenção de um compactado verde, que possua boa resistência e usinabilidade, em função do ligante utilizado (FANTOZZI et al., 1997; KLOCKE, GERENT e SCHIPPERS, 1997).

Um formato complexo de componentes cerâmicos requer uma usinagem custosa se o formato for obtido no estado sinterizado. Por exemplo, o custo relativo 
da usinagem final de válvulas de nitreto de silício é 44\%, considerando que o custo para dar a forma é de $6 \%$ e $23 \%$ é o custo do pó. Devido à demanda econômica, uma mudança para a usinagem no estado verde é favorável, assim como a redução do custo pela recuperação do pó removido (BOECKER e KRUENER, 1993 apud WESTERHEIDE et al., 1997).

Como mencionado, há a possibilidade de redução de custo adicional pela recuperação do pó removido durante usinagem em verde e o uso repetitivo desse pó para a obtenção de peças verdes. A reutilização do pó é proveitosa desde que não haja diminuição das propriedades mecânicas na técnica de compactação e nem alteração química e de tamanho dos grãos, que possam causar a impossibilidade da usinagem em verde. Além disso, é necessário evitar impurezas introduzidas no processo de compactação pelo molde e, também, pelo manuseio (WESTERHEIDE et al., 1997).

Em um experimento realizado com o pó recuperado, foi demonstrada densidade um pouco maior a pressões de compactação menores, ver Figura 2.14. A investigação de peças verdes e sinterizadas obtidas por pó recuperado tem demonstrado que é um potencial para a redução do custo através do uso repetitivo do pó cerâmico (WESTERHEIDE et al., 1997).

Um estudo foi realizado por EL-Wardany (2009) na manufatura de um molde para prensagem isostática de compactados, que seriam submetidos à usinagem em verde para a obtenção de uma peça complexa (Figura 2.15). A superfície interna do molde sendo fabricada com a tolerância especificada do projeto propiciou uma redução de $20 \%$ no custo da usinagem em verde, pois permitiu a obtenção da tolerância específica na superfície interna da peça durante o processo de prensagem, como ilustra a Figura 2.16. 


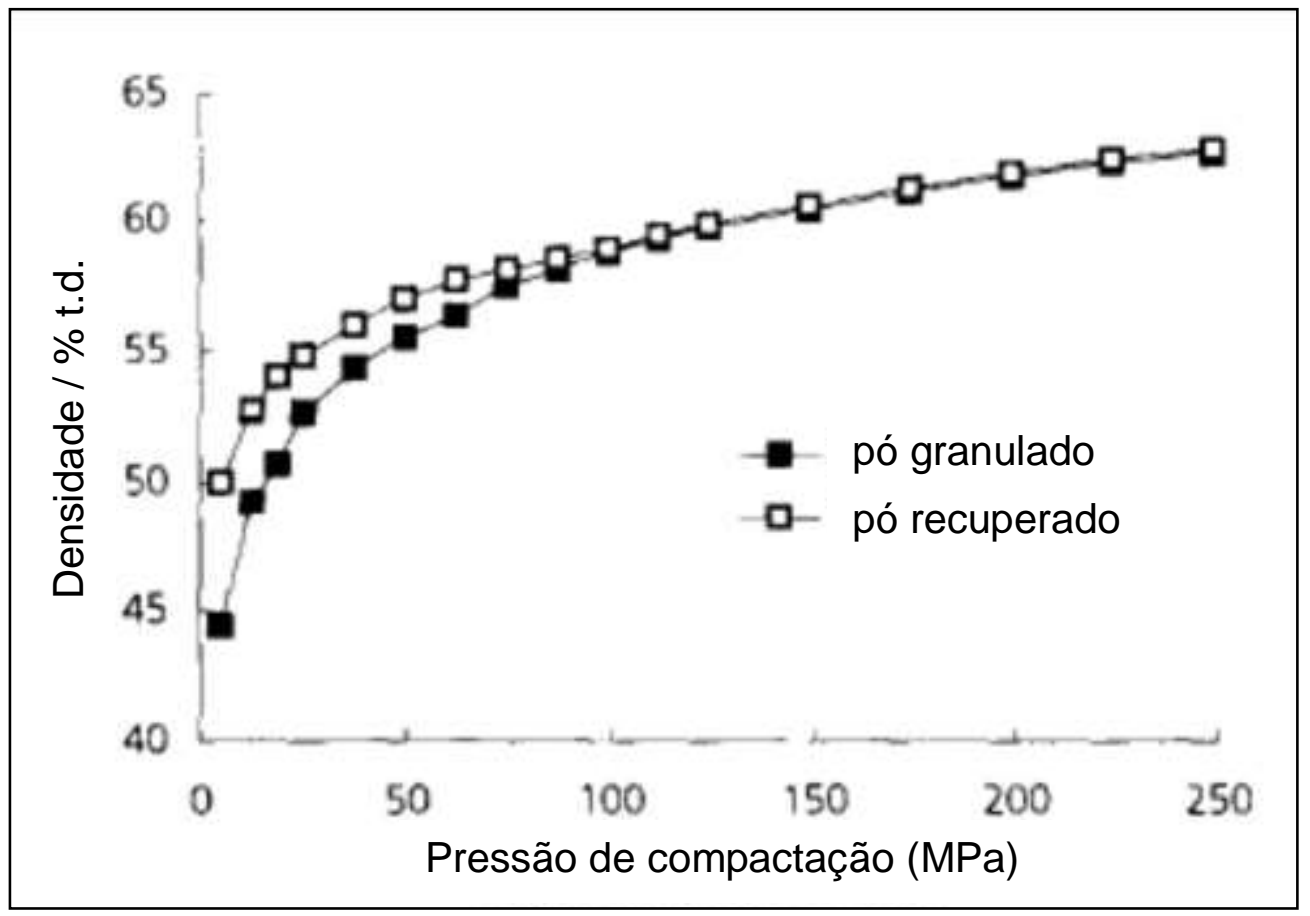

Figura 2.14 - Comportamento da compactação de pó de alumina granulada e recuperada (WESTERHEIDE et al., 1997).

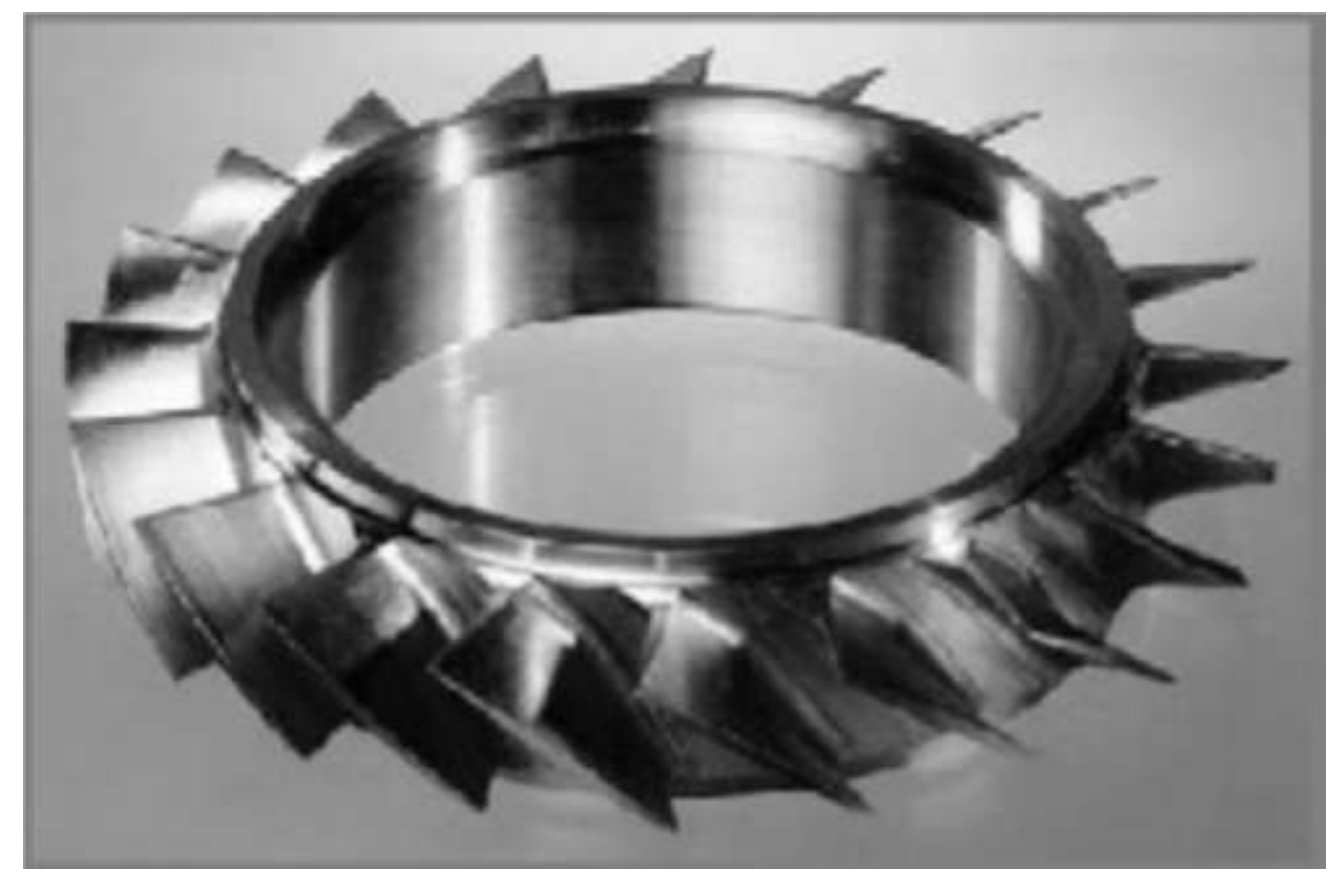

Figura 2.15 - Configuração de uma peça com paredes finas (EL-WARDANY et al., 2009). 


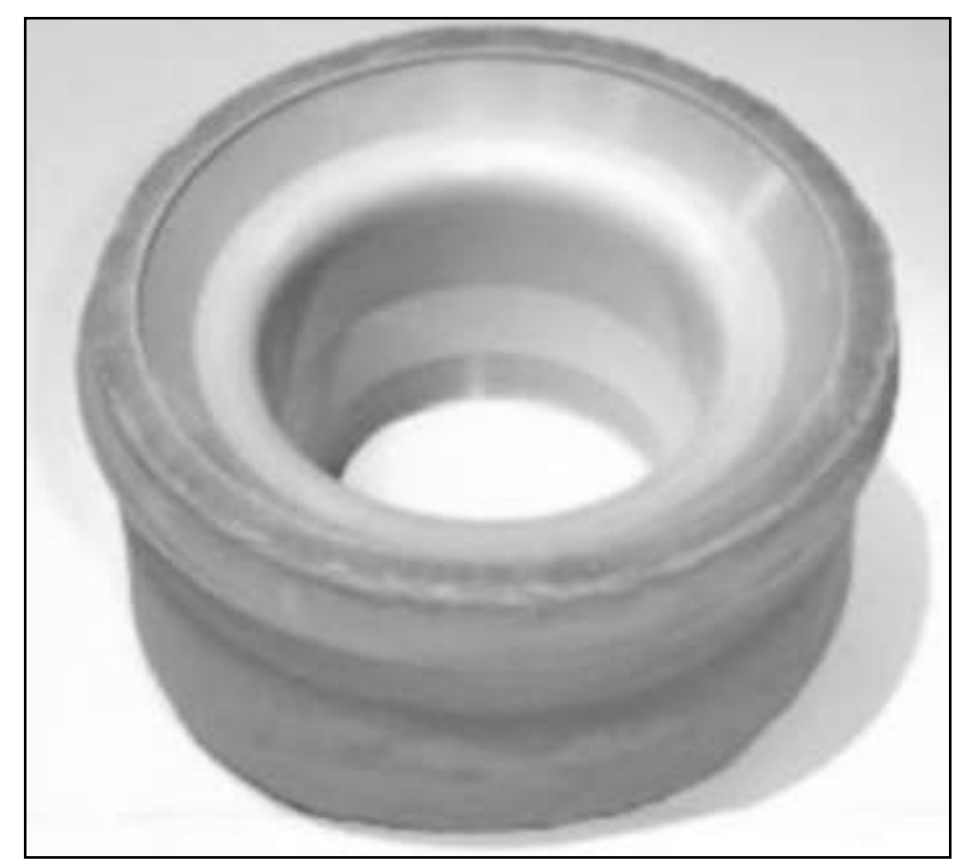

Figura 2.16 - Compactado de carboneto de silício com a parte interna em seu formato final (EL- WARDANY et al., 2009. adaptado).

\subsection{Usinagem em verde}

Usinagem de cerâmica em verde, também denominada de usinagem de cerâmica em seu estado verde, é a aplicação da usinagem pós-processo de conformação. Essa usinagem tem sido proposta como um método de manufatura near-net-shape competitivo para a cerâmica, desde o início da década de 90, mas tem como dificuldade a baixa resistência mecânica e a fragilidade dos corpos, dificuldade proveniente dos métodos convencionais de conformação, como a prensagem a seco, onde a resistência mecânica em verde obtida é, normalmente, menor que 5 MPa (BUTLER e DAWSON, 1990 apud LIU et al., 2010).

Essa usinagem é, também, usualmente referida como usinagem no estado não sinterizado do material cerâmico. Pode ser aplicada para solucionar limitações de formatos, os quais os métodos de conformação se mostram incapazes de gerar nas peças devido a custo, qualidade e rendimento. Exemplos incluem passos de rosca de diâmetros externos e internos, furos e rasgos laterais e recursos não convenientes aos movimentos da conformação (SHEPPARD, 1999).

A usinagem em verde é uma técnica amplamente utilizada na fabricação de componentes cerâmicos (LINDIQVIST e CARLSTRON, 2002). É desejada para fazer peças cerâmicas com formas complexas a baixo custo. Porém, existem poucos 
trabalhos publicados sobre usinagem em verde, principalmente devido à insuficiente resistência das peças para suportar os processos convencionais de usinagem (BESSHI, SATO e TSUTSUI, 1999).

Essa usinagem começa com um compactado geometricamente simples, oferecendo consideráveis vantagens em termos de qualidade, eficiência econômica e versatilidade em alguns casos, proporcionando um alto grau de flexibilidade de forma anterior a sinterização. (HALCOMB e REY, 1982 apud KLOCKE, GERENT e SCHIPPERS, 1997; RICHERSON, 1992; SPANG, 1989 apud KLOCKE, GERENT e SCHIPPERS, 1997)

Outras vantagens descritas por King (2002) da usinagem em verde são:

- não necessidade de ferramental dispendioso;

- obtenção de densidade uniforme e alta;

- poder modelar peças em dimensões precisas.

A usinagem em verde oferece, também, várias vantagens distintas comparado com outras tecnologias correntes usadas para a fabricação near-netshape de cerâmica, em termos de eficácia de custo e acabamento (SU, DHARA e WANG, 2008).

A usinagem por controle numérico computadorizado (CNC) tem sido, prevalentemente, usada como método de prototipagem rápida, para obter peças de formatos complexos, devido a sua eficácia de custo (HASSOLD, 1995 apud KOH e HALLORAN, 2004).

A tecnologia da usinagem por CNC fornece uma aproximação top-down a qual um compactado cerâmico é usinado no seu formato desejado (GIORDANO, 2003 apud SU, DHARA e WANG, 2008).

Com o desenvolvimento das fresadoras CNC, novas possibilidades de usinagem em verde de materiais cerâmicos de formas complexas estão se abrindo. Isso pode ser uma rota atrativa, especialmente para a fabricação de protótipos e pequenas produções em série (LINDIQVIST e CARLSTRON, 2002).

Tal aplicação pode ser utilizada na fabricação de implantes dentários e ortopédicos, onde somente um produto específico e personalizado é necessário (DHARA e SU, 2005). 


\subsubsection{Influência do ligante na usinagem em verde}

Durante a usinagem em verde pode ocorrer aderência do ligante nos poros do abrasivo ou nas ranhuras da ferramenta de corte. Isso pode ser evitado pela seleção apropriada do tamanho do grão e da porosidade ou da ranhura. O ligante também pode ser removido por métodos de limpeza, tal como o jateamento, para promover uma nova e limpa superfície abrasiva (SHEPPARD, 1999).

O ligante termofixo promove uma alta homogeneidade do compactado verde, que durante ensaio de flexão levou a uma ruptura totalmente transgranular e frágil, demonstrando alta resistência mecânica. Já o ligante termoplástico forma uma camada ao redor dos grânulos, que não desaparece após a compactação, levando a uma ruptura parcial ou totalmente intergranular dependendo da quantidade do ligante. O ensaio de flexão demonstrou menor resistência mecânica com uma ruptura controlada (DESFONTAINES, GONON e FANTOZZI, 2005).

Durante a usinagem de uma peça com polímero termoplástico, o material pode ser removido em modo dúctil ou frágil, dependendo da característica da temperatura de transição vítrea $(\mathrm{Tg})$ deste polímero. Se a temperatura local for menor que o $\mathrm{Tg}$, o material tende a ser removido no modo frágil, por outro lado, com a temperatura local ultrapassando o Tg, a remoção é no modo dúctil, promovendo o derretimento do ligante. Um bom acabamento superficial será observado em uma remoção dúctil, devido a remoção frágil causar o dilaceramento e arrancamentos de partículas cerâmicas, embora o calor gerado na zona de corte possa afetar o acabamento da mistura termoplástica (HOH e HALLORAN, 2004).

Kumar et al. (2000) estudou a resistência mecânica em verde de corpos cerâmicos com relação ao $\mathrm{Tg}$ do ligante polimérico, sugerindo o ligante acrílico apropriado na usinagem de peças verdes em processos como o torneamento, fresamento, retificação e outros.

Em alguns trabalhos, tem sido mostrado que baixa resistência mecânica permite uma melhor usinabilidade, mas somente até onde o manuseio do compactado seja possível (NUNN e KIRBY, 1996; BIRKBY et al., 1994). Também foi observado que diferença na resistência em verde resulta em diferentes comportamentos de corte e fratura, conduzindo a uma fratura intergranular ou transgranular para os compactados prensados em verde (DESFONTAINES et al., 2005; BIRKBY et al., 1994). 


\subsubsection{Máquinas para usinagem em verde}

A demanda por componentes cerâmicos, com maior complexidade de forma, faz com que a usinagem em verde se torne ainda mais presente na fabricação de peças cerâmicas. Como ela permite baixo consumo de energia, menor desgaste da ferramenta e alta taxa de remoção de material, a usinagem em verde tem sido praticada em escala comercial por diferentes processos de usinagem, que incluem a furação, a retificação, o fresamento, o torneamento e outros. Em contraste, a retificação é o único processo de usinagem aplicado na usinagem de cerâmicas sinterizadas (SCHELLER e WANMUHAMAD, 1996 apud KAMBOJ, DHARA e BHARGAVA, 2003).

Retificadoras convencionais, usadas na indústria de metal, podem ser usadas para usinagem em verde de cerâmicas, com a vantagem de necessitarem muito menos energia do que na retificação de metais. Podem ser incluídos, também, tornos verticais e horizontais para o torneamento de diâmetros; fresamento para faces planas, canais e furos; e furadeiras para furos. Como exemplo, em operações de usinagem por revolução, tais como as obtidas com um torno, o compactado é fixado em um cabeçote rotativo e sua superfície é colocada contra uma ferramenta de corte rotativa ou revestida por material abrasivo que promove a usinagem, como mostra o esquema da Figura 2.17 (SHEPPARD, 1999).

As peças são geralmente fixadas às máquinas por fixação direta (nas pinças ou castanhas) ou coladas em uma base metálica que é posteriormente fixada a máquina. Para peças que requerem usinagem a seco, tais como componentes eletrônicos e outras peças de engenharia, não existirá solução refrigerante para carregar o resíduo e preveni-lo de aderir aos componentes da máquina, dessa forma, qualquer superfície exposta será coberta com o resíduo, que poderá danificar a máquina de alguma forma. Por essa razão, os controles críticos funcionais da máquina (tais como as guias, parafusos e componentes do motor) devem ser cuidadosamente protegidos. Se possível, o resíduo (poeira) deve ser removido diretamente do ponto de usinagem assim que é formado. Completo enclausuramento da máquina protege tanto a área de trabalho quanto o operador da máquina, além de reduzir o barulho (SHEPPARD, 1999). 


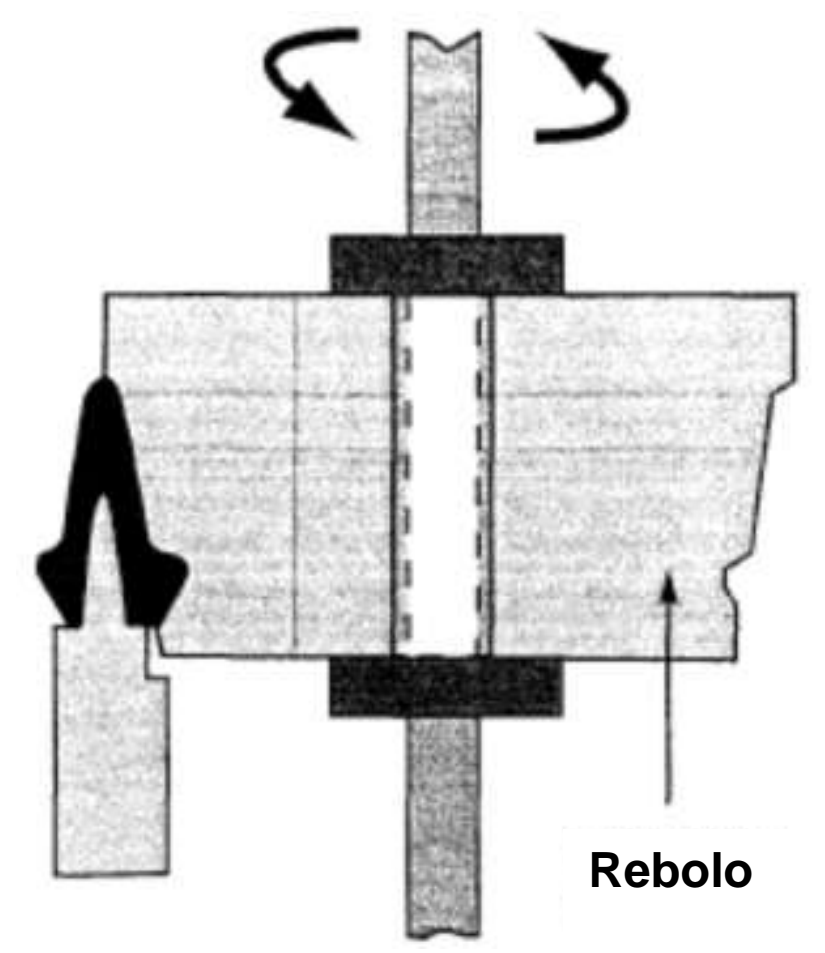

Figura 2.17 - Retificação de perfil de cerâmica em verde em um torno vertical (SHEPPARD, 1999).

\subsubsection{Exemplos de máquinas aplicadas em usinagem em verde}

No trabalho de Kamboj, Dhara e Bhargava (2003), foi feita a aplicação dos processos de furação, fresamento e retificação na usinagem em verde de alumina, utilizando máquinas convencionais. Testes parecidos já haviam sido feitos por Scheller (1994), aplicando os processos de fresamento e furação utilizando uma máquina CNC.

Semelhante aos trabalhos anteriores, Su et al. (2008), utilizaram uma fresadora CNC (MDX 650) da Roland DG Ltda. na usinagem em verde de zircônia, para a obtenção de molar dentário.

No trabalho de Rem et al. (2002), foi aplicado o processo de retificação, utilizando um tipo de retificadora sem-centros com o auxílio de dois rebolos perfilados, na fabricação de esferas de nitreto de silício (Figura 2.18).

Filser, Kocher e Gauckler (2003) propõem conceitos e protótipos de máquinas CNC, para usinagem em verde, contendo de 3 a 5 graus de liberdade, utilizando encoders para melhorar o posicionamento, podendo conter mais de um cabeçote para a usinagem e com mudança automática de ferramenta (Figura 2.19). 


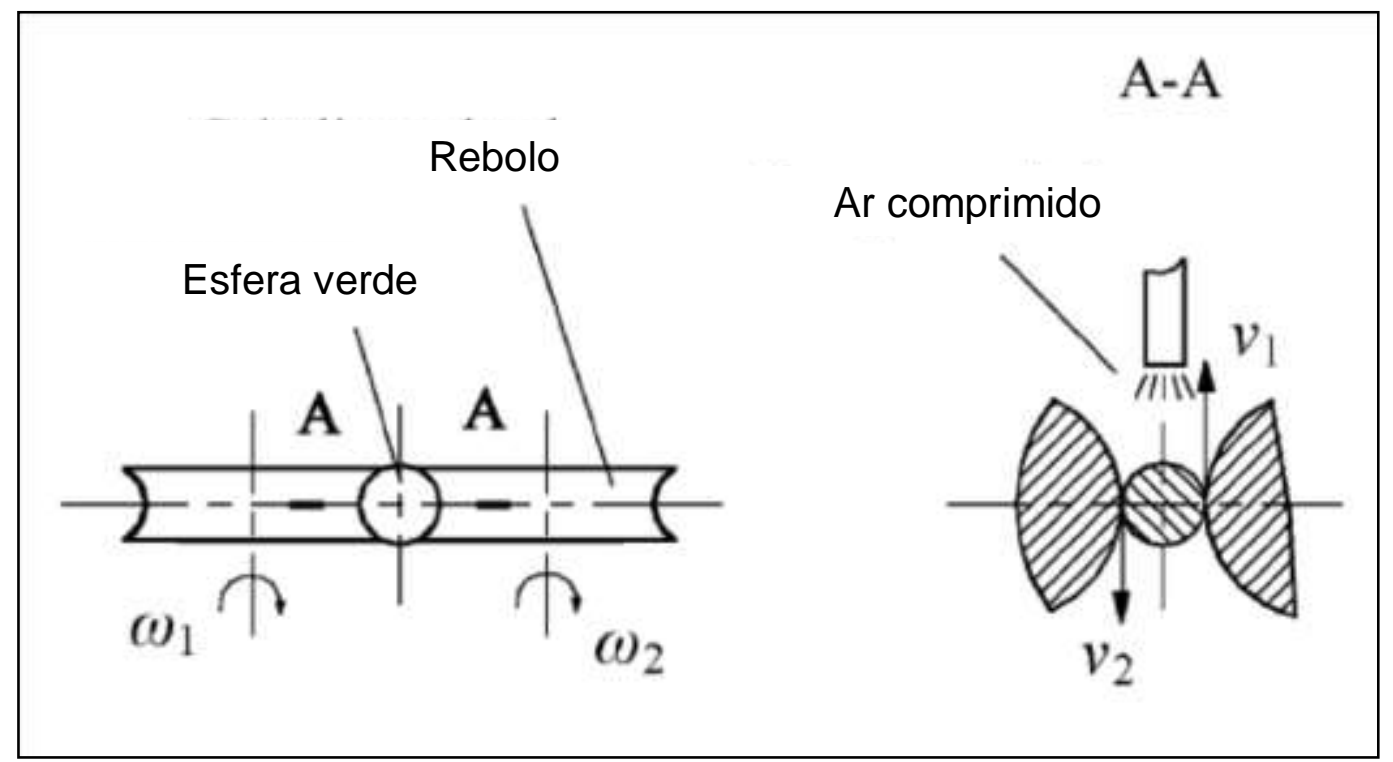

Figura 2.18 - Modelo com dois rebolos perfilados (REM et al., 2002).

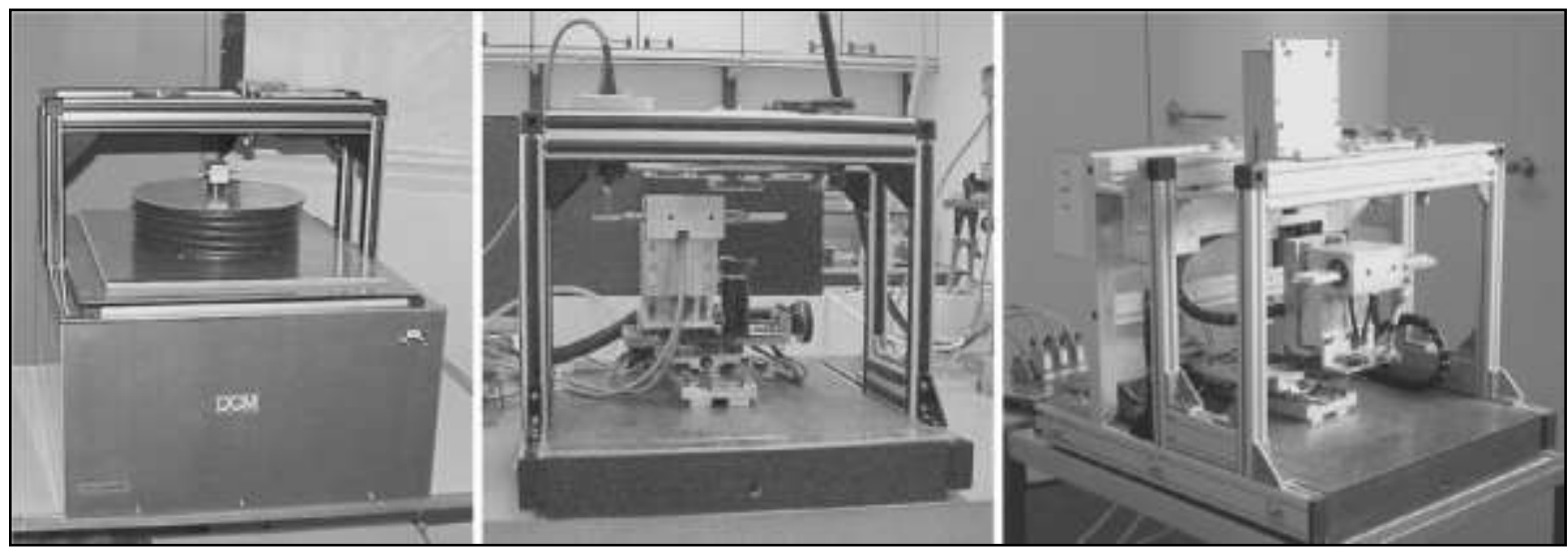

Figura 2.19 - Protótipos de máquinas (FILSER, KOCHER E GAUCKLER, 2003).

$\mathrm{Na}$ usinagem em verde de peças de carboneto de silício com paredes finas, realizado no trabalho de El-Wardany et al. (2009), foi aplicado uma máquina CNC de 5 eixos para permitir a usinagem da peça proposta (Figura 2.20). 


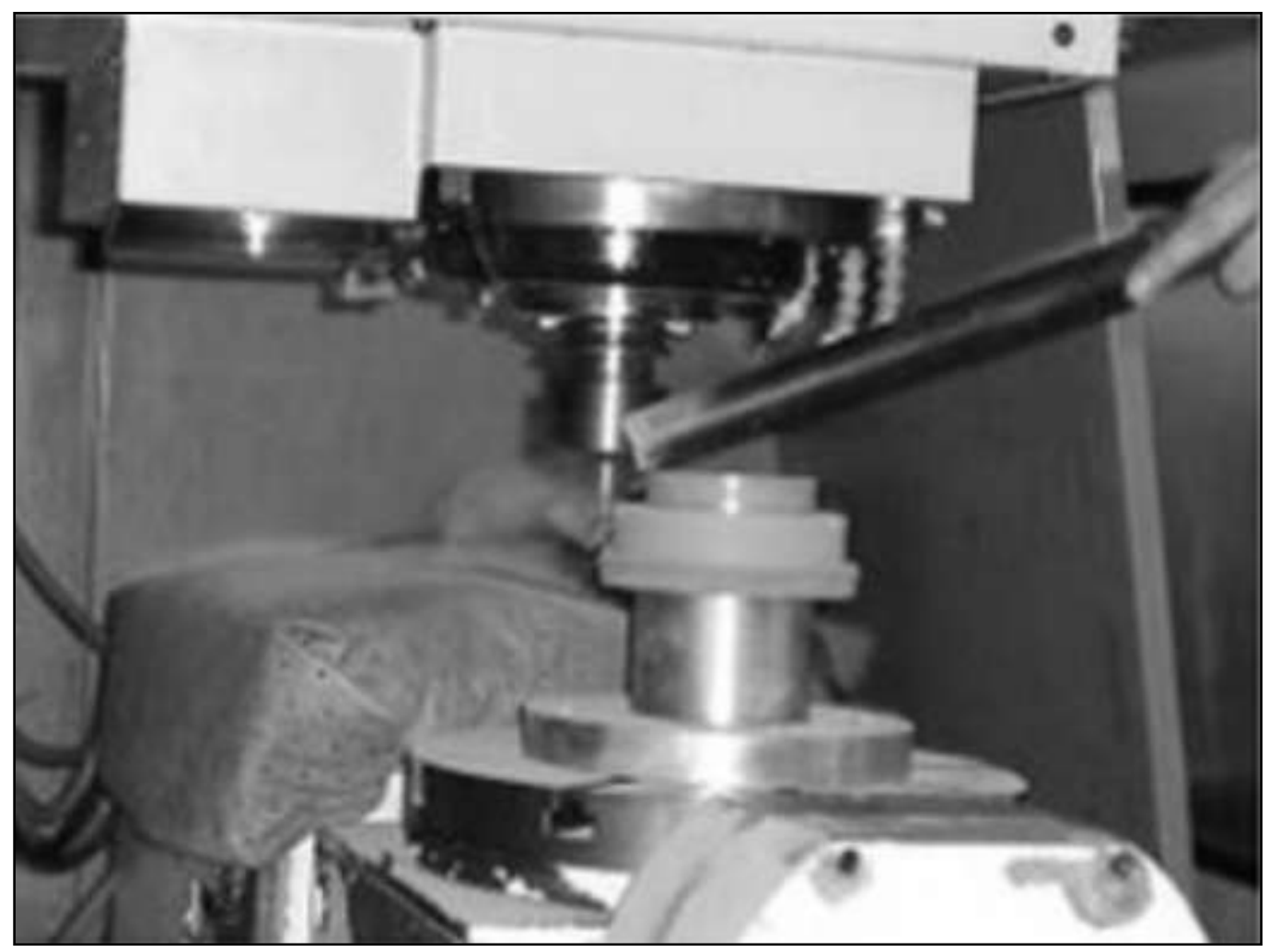

Figura 2.20 - Máquina CNC de 5 eixos aplicada na usinagem em verde (ELWARDANY et al., 2009, adaptado).

\subsubsection{Nível de acabamento alcançado por cada tipo de máquina}

Apesar de ser possível a aplicação de máquinas de usinagem convencionais ou CNC na usinagem em verde, toda cautela deve ser tomada com o nível de acabamento (rugosidade) que cada máquina permite obter, de acordo com 0 processo de usinagem realizado por cada uma. A escolha errônea do processo de usinagem, realizado por uma máquina, poderá não atender o nível de acabamento especificado pelo projeto, inviabilizando a produção de uma peça. Processos de furação, fresamento, torneamento e retificação permitem alcançar diferentes níveis de rugosidade.

\subsubsection{Efeito do material da ferramenta na usinagem em verde}

A seleção da ferramenta tem forte influência nas características do processo de fabricação. Richerson (1992) explica que é possível utilizar ferramentas de aço rápido, metal duro ou revestidas, mas cada cerâmica em verde pode exigir um tipo específico. Devido à natureza altamente abrasiva dos resíduos e partículas geradas durante a usinagem, existe um alto desgaste das ferramentas. Em alguns casos, a 
ferramenta se desgasta tão rápido que um cuidado extremo deve ser tomado para evitar danos à peça, como é observado na Figura 2.21. Após um comprimento de corte de apenas poucos metros se pode notar um desgaste acentuado quando se usa uma ferramenta de carbeto de tungstênio ou cerâmica policristalina, já na aplicação de ferramentas de diamante policristalino (PCD) ou CBN tem-se a vida aumentada, em várias vezes.

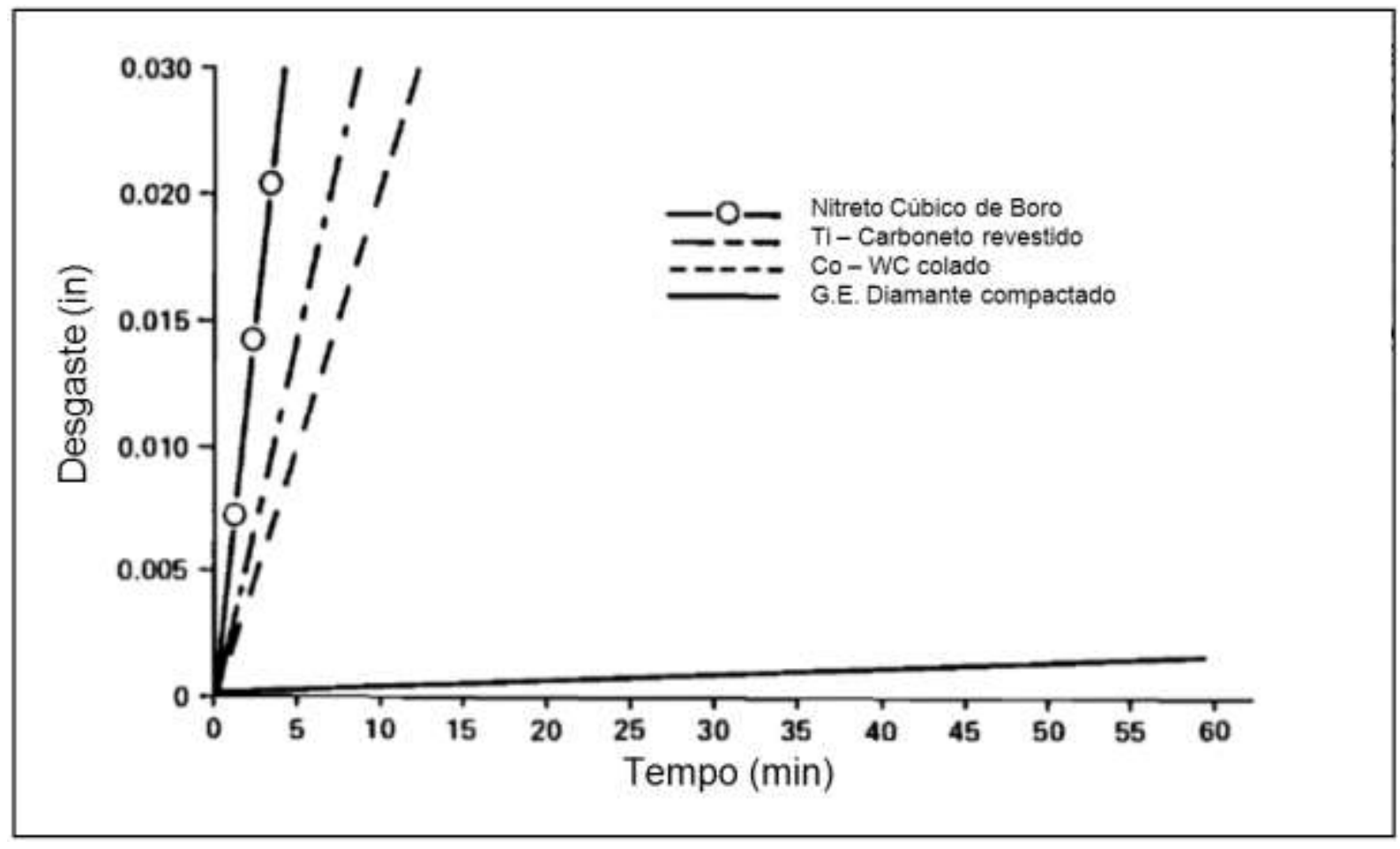

Figura 2.21 - Desgaste para ferramentas de diferentes materiais na usinagem em verde de um compactado de nitreto de silício pré-sinterizado na fabricação por colagem de reação (RICHERSON, 1992, adaptado).

As ferramentas empregadas podem ser de ponta única, quando se necessita da máxima flexibilidade no formato da peça e alta taxa de remoção de material; perfiladas, com a aresta cortante no formato do perfil da peça; e com múltiplas arestas, como no caso de um rebolo. A dureza da aresta de corte da ferramenta é um fator crítico. Um perfil completo pode ser obtido na peça quando uma ferramenta de corte perfilada é utilizada. A ferramenta perfilada pode ser uma pastilha de carbeto de tungstênio ou um rebolo abrasivo que rotaciona contra a peça de cerâmica em verde. A seleção do processo de usinagem está diretamente relacionada com a ferramenta de usinagem. Para ferramentas de ponta única o torneamento e mandrilhamento são associados. Para ferramentas perfiladas pode- 
se empregar o torneamento, o fresamento, a furação e o mandrilhamento. Para rebolos o processo associado é o da usinagem abrasiva (retificação) (RICHERSON, 1992).

Em estudos preliminares utilizando ferramentas de aço rápido, revestidas de carboneto ou revestidas de diamante na usinagem em verde, pôde ser observado que tanto as ferramentas em aço rápido como as revestidas de carboneto se desgastaram muito rapidamente durante a usinagem em verde. Foram observadas marcas pretas ao longo da trajetória da ferramenta na peça, havendo um aquecimento excessivo queimando o ligante, além de levar a perda da eficiência da usinagem e introduzir material metálico da ferramenta na peça cerâmica devido ao desgaste excessivo (DHARA e SU, 2005).

A Figura 2.22 demonstra uma comparação do desempenho de dois diferentes materiais aplicados como ferramentas na usinagem em verde, em (a) ferramentas revestidas com carboneto e em (b) ferramentas revestidas de diamante. A ferramenta revestida de diamante, além do melhor acabamento superficial, demonstrou desgaste desprezível, mesmo após longos períodos de usinagem. Não foram observadas marcas pretas ao longo da trajetória da ferramenta. Por esse motivo, ultimamente, ferramentas revestidas de diamante têm sido utilizadas em estudos (DHARA e SU, 2005).

Ferramentas rotativas revestidas com partículas duras são outra opção, se tornando uma mistura de fresamento com retificação. No trabalho de Lee e Lee (2004), peças de alumina em verde foram micro furadas utilizando micro brocas revestidas de diamante. A broca com revestimento de diamante foi utilizada devido ao desgaste dessa operação ser muito severo, a mesma é mostrada na Figura 2.23, e sua dimensões estão na Tabela 2.2.

O CBN também pode ser utilizado na fabricação de ferramentas para a usinagem em verde, apresentando características distintas em relação ao diamante. O CBN possui um grau de dureza abaixo do diamante, porém, seus grãos possuem uma rugosidade mais pronunciada e de maior fator crítico, que leva a uma influência no desempenho de rebolos de retificação. Possui, também, uma morfologia angular de maior aspereza que promove uma melhor ancoragem mecânica na alma das ferramentas onde é aplicado (MARINESCU et al., 2007). 


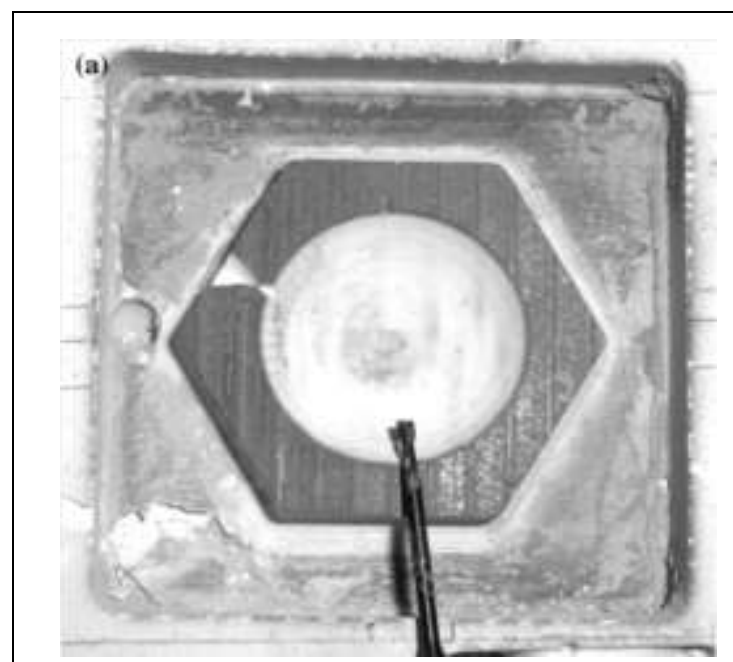

(a)

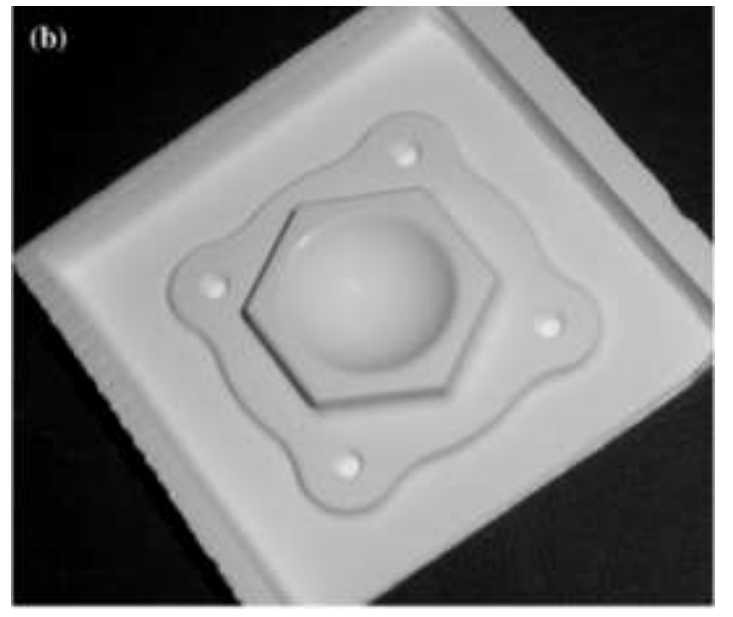

(b)

Figura 2.22 - Peças usinadas em verde utilizando ferramentas (a) revestidas de carboneto e (b) revestidas de diamante (DHARA e SU, 2005, adaptado).

(a)

(c)

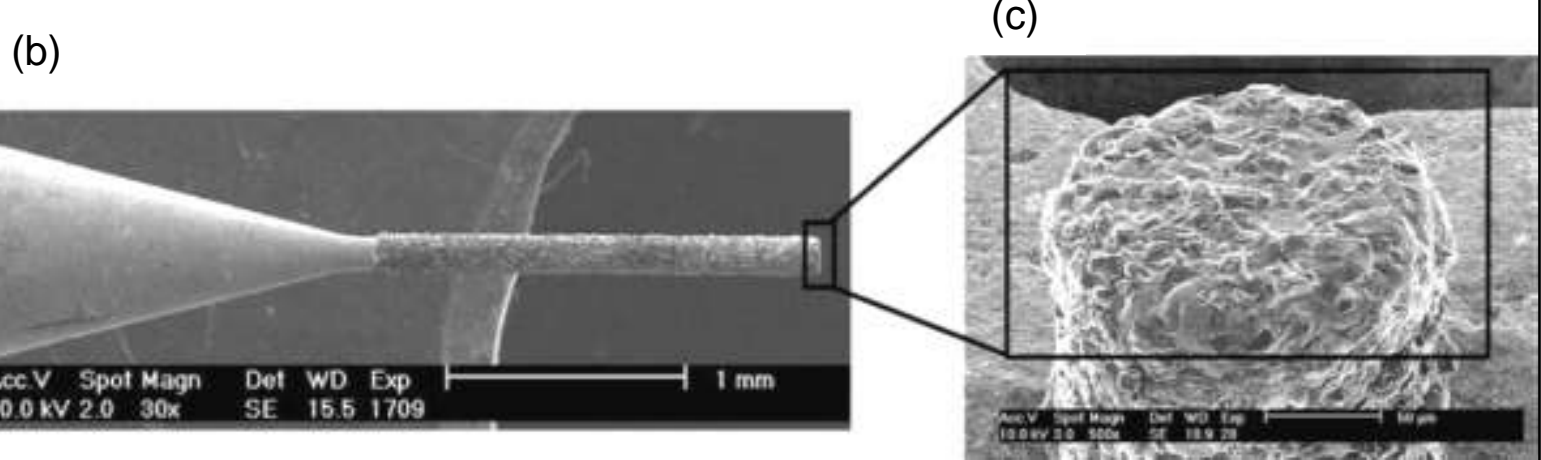

Figura 2.23 - Micro broca com abrasivo de diamante: (a) configuração, (b) imagem de MEV magnificada e (c) ponta da micro broca com maior magnificação (LEE e LEE, 2004). 
Tabela 2.2 - Especificação do abrasivo de diamante da micro broca (LEE e LEE, 2004).

\begin{tabular}{|c|c|}
\hline Material da matriz & Níquel \\
\hline Diâmetro, D $(\mathrm{mm})$ & 0,2 \\
\hline Diâmetro da haste de WC, Ds $(\mathrm{mm})$ & 0,15 \\
\hline Comprimento do revestimento de diamante, Ld $(\mathrm{mm})$ & 2 \\
\hline Comprimento total, L $(\mathrm{mm})$ & 38 \\
\hline Granulometria do abrasivo de diamante (mesh) & 1000 \\
\hline
\end{tabular}

\subsubsection{Efeito da geometria da ferramenta na usinagem em verde}

Duas ferramentas pontas montadas diferentes, revestidas de diamante, uma com a ponta em formato plano e outra com a ponta em formato arredondado, foram utilizadas para analisar o efeito da geometria da ferramenta no acabamento da usinagem em verde de peças planas. As superfícies usinadas, apresentadas na Figura 2.24, demonstram que a ferramenta com ponta arredondada apresentou pior acabamento em relação à de ponta plana, provavelmente devido a característica de gerar uma marca regular em seu trajeto, levando a ferramenta de face plana a apresentar valores de rugosidade melhores em sua comparação (DHARA e SU, 2005).

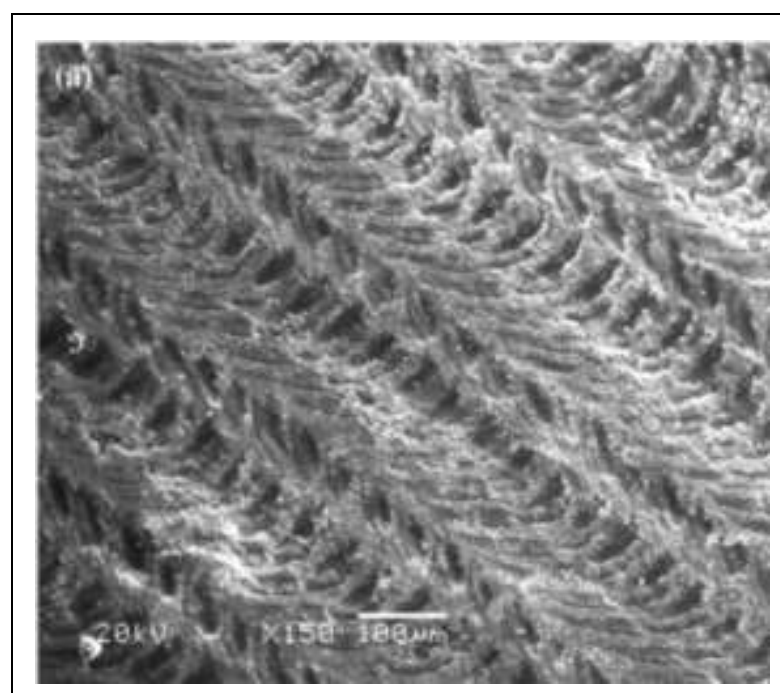

(a)

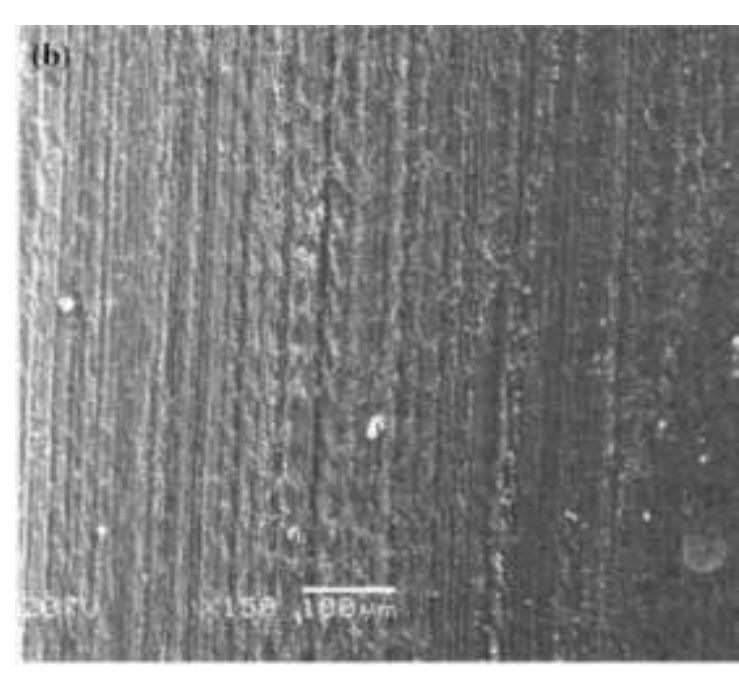

(b)

Figura 2.24 - Características da superfície usinada utilizando ferramenta revestida de diamante (a) arredondada e (b) plana (DHARA e SU, 2005, adaptado). 


\subsubsection{Problemas com a usinagem em verde}

Pesquisas em usinagem em verde de cerâmica são poucas, o know-how é principalmente empírico e muitos problemas permanecem para serem resolvidos para tornar a usinagem em verde economicamente atrativa. Um dos pontos mais críticos a ser investigado é a caracterização da usinabilidade das peças em verde. Trabalhos industriais são baseados na experiência, sendo muito difícil predizer se uma peça cerâmica irá suportar a usinagem em verde e qual a melhor estratégia para a realização do trabalho (KLOCKE, GERENT e SCHIPPERS, 1997).

Problemas surgem de trincas induzidas pela fixação durante a usinagem, da rugosidade e dos defeitos nas bordas. Esses tipos de danos devem ser quantificados e o efeito na qualidade do componente cerâmico deve ser avaliado. Dependendo do método de usinagem é possível avaliar os danos nas superfícies do compactado verde por diferentes testes de resistência mecânica (BORTZMEYER, LANGGUTH e ORANGE, 1993).

Peças prensadas a seco são consideradas por obedecer muito bem à estatística Weibull e à relação entre intensidade de tensão e energia da fratura. Métodos adequados de teste devem ser encontrados para caracterizar os componentes cerâmicos, tão bem como para determinar os dados do material (BORTZMEYER, LANGGUTH e ORANGE, 1993).

Durante a retificação de peças cerâmicas em verde foi observado que os rebolos ficam emplastados devido ao empacotamento das partículas cerâmicas entre as partículas do abrasivo. Esse empastamento do rebolo ocorre rapidamente e se torna severo na presença do ligante. A extensão do empastamento aumenta com o aumento da quantidade do ligante no compactado verde, o que reduz a eficiência da retificação, sendo observado um rápido aumento das forças de corte medidas. A remoção das partículas do pó aderidas às partículas abrasivas do rebolo, após a usinagem de peças contendo ligante é difícil mesmo com a ação mecânica de uma escova. Entretanto, rebolos emplastados por pó proveniente da usinagem de peças pré sinterizadas podem ser facilmente limpos (KAMBOJ, DHARA e BHARGAVA, 2003).

Fresamento pode ser realizado em compactados, obtidos por gelcasting, com forças de corte razoavelmente baixas. Mas a retenção de borda no fresamento pode ser um problema em virtude da natureza frágil dos compactados, contudo um 
acabamento superficial razoável pode ser obtido pelo fresamento (KAMBOJ, DHARA e BHARGAVA, 2003).

King (2002) menciona alguns fatores chave que os compactados cerâmicos devem possuir para a otimização da usinagem em verde:

- dureza, tenacidade e resistência altas;

- tamanho de grão;

- porosidade;

- propriedades térmicas;

- propriedades elásticas.

A ocorrência de alta densidade e/ou resistência mecânica no estado verde não necessariamente significa boas características de usinagem. Um estudo mostrou que um lubrificante desempenha papel crítico na determinação do nível de lascamentos da peça esperado no lado da saída da ferramenta na furação. A Figura 2.25 mostra uma peça perfurada com lascamento da borda causado pela saída da ferramenta. $O$ estudo sobre a adição apropriada de lubrificante, durante o processo de usinagem, levou a diminuição do lascamento em função do aumento da quantidade de lubrificante, Figura 2.26 (DEGNAN, KENNEDY e SHIPWAY, 2007).

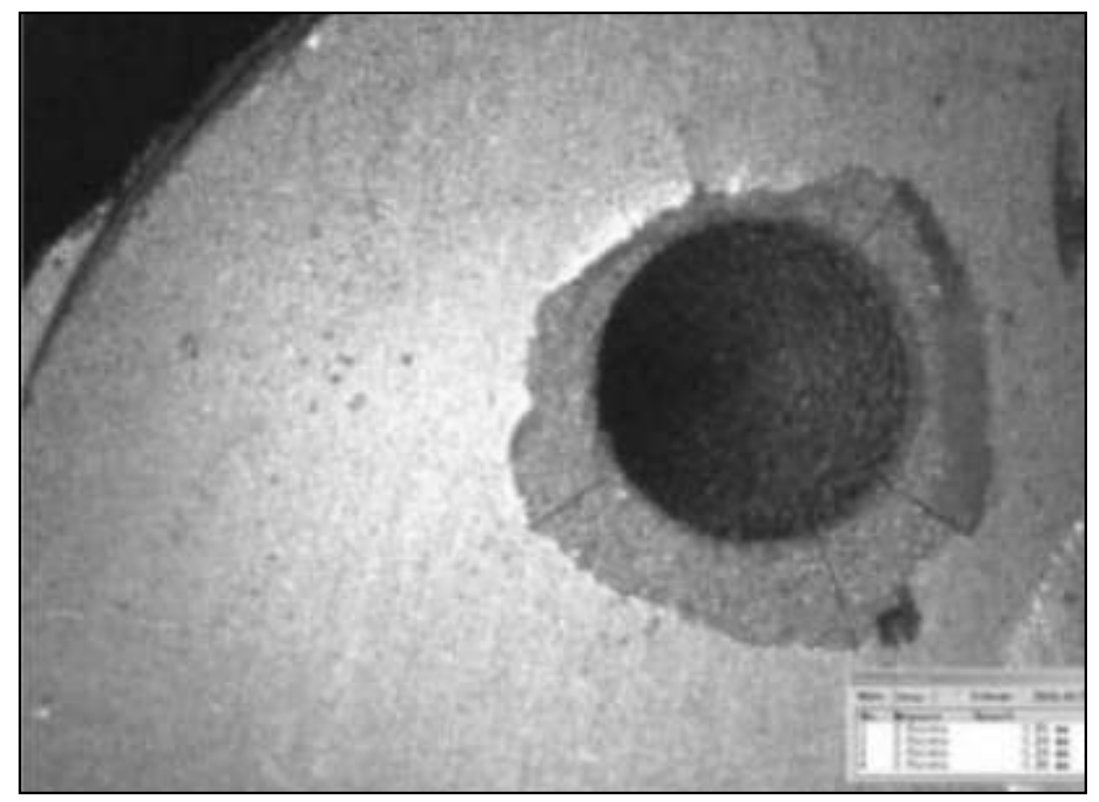

Figura 2.25 - Exemplo de um tipo de imagem utilizada para acessar os lascamento no lado da saída da ferramenta de uma peça em verde furada (DEGNAN, KENNEDY e SHIPWAY, 2007, adaptado). 


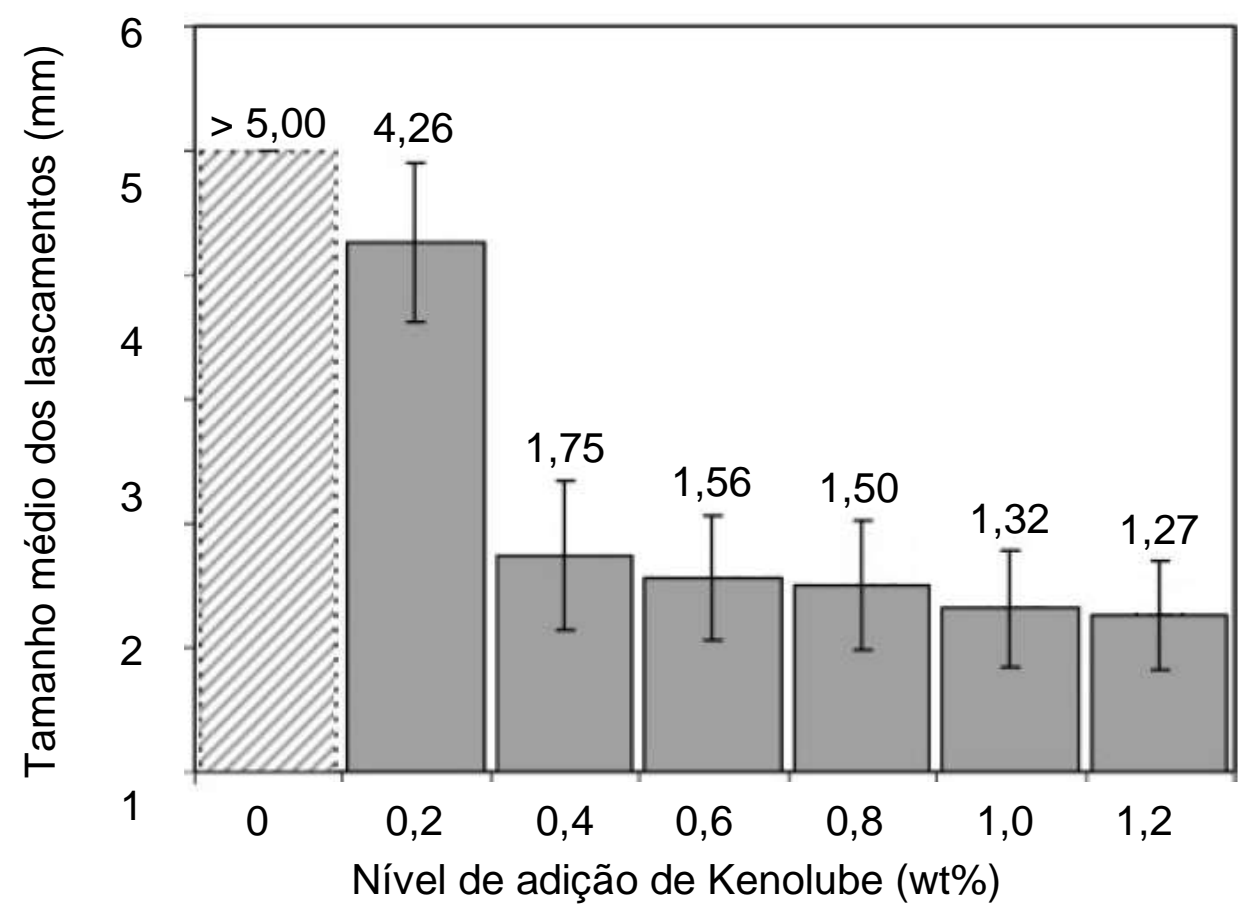

Figura 2.26 - Tamanho médio de lascamento em relação ao nível de Kenolube adicionado, sendo as peças compactadas a $85 \mathrm{MPa}$ (DEGNAN, KENNEDY e SHIPWAY, 2007).

\subsubsection{Aplicação da usinagem em verde}

Um exemplo comercial da aplicação da usinagem em verde é na manufatura de velas automotivas. Um compactado é prensado isostaticamente e então retificado por rebolo perfilado. Esse processo é muito eficaz e produz peças densas com precisão e uniformidade (KING, 2002).

A usinagem em verde pode ser empregada também na fabricação de esferas cerâmicas, com o objetivo de obter alta precisão dimensional e reduzir o sobrematerial das esferas sinterizadas, sendo este um passo importante na fabricação das esferas (PAM, 2000 apud REN et al., 2002).

Peças cerâmicas de alumina e nitreto de silício em verde, preparadas por gelcasting, mostraram ser facilmente usináveis usando ferramentas de carboneto de tungstênio. Pode ser observado que a formulação gelcasting, a qual utiliza um agente ligante com alto peso molecular, permite características de usinagem superior (NUM e KIRBY, 1996).

No trabalho de Bukvic (2011), foi aplicada a usinagem em verde, com ferramenta de carboneto de tungstênio, no torneamento de tarugos de alumina 
spray-dried com ligante PVAl. Seu objetivo foi reduzir o gradiente de densidade causado por prensagem uniaxial de simples ação. A redução do gradiente foi alcançada pela remoção de camadas de sobrematerial que continham maiores diferenças de densidade em relação ao restante da peça (Figura 2.27).

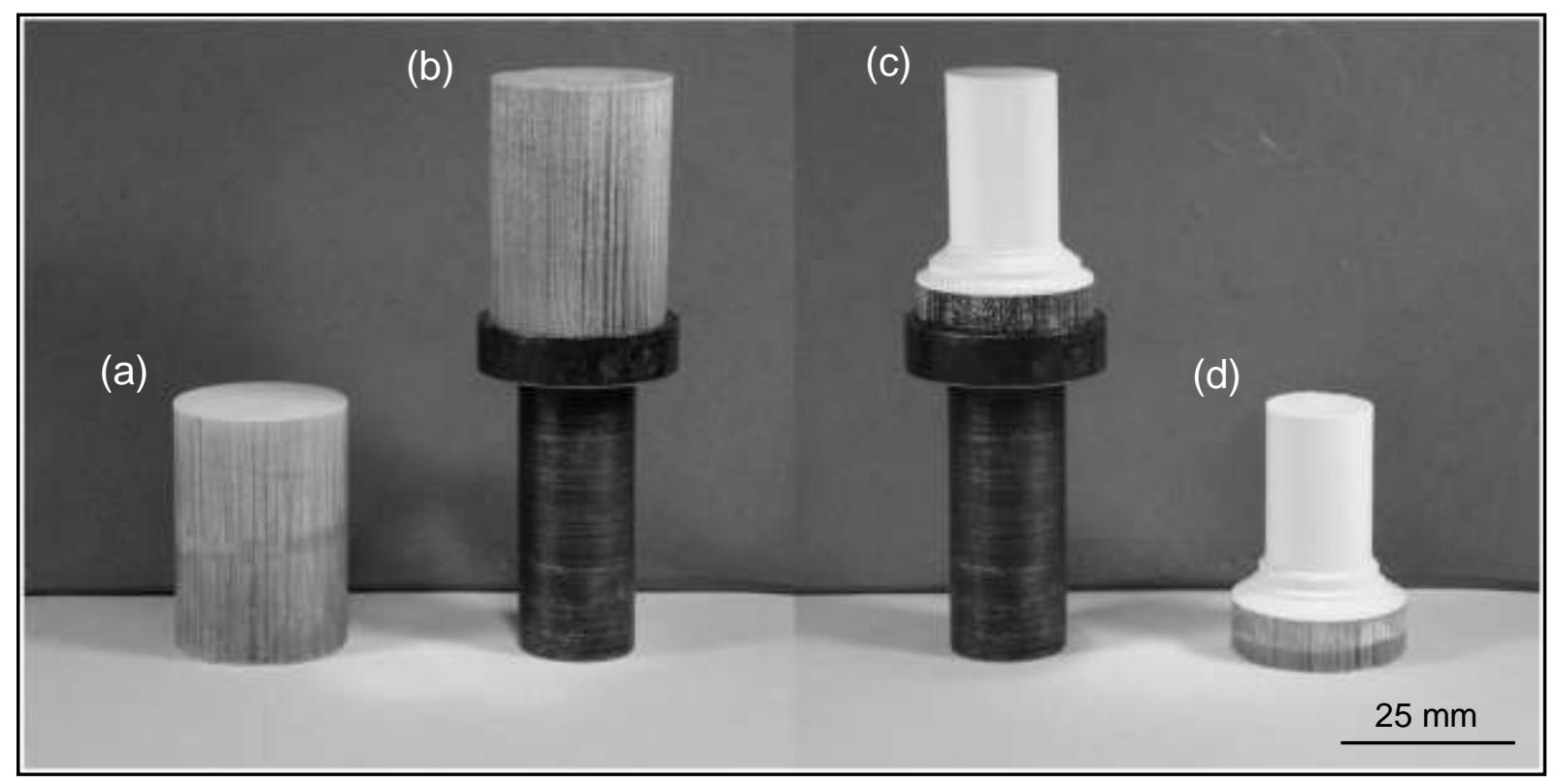

Figura 2.27 - Corpo-de-prova antes de fixado à base (a), fixado (b), usinado (c) e destacado (d) (BUKVIC, 2011).

A usinagem por máquina CNC aplicada na usinagem em verde de peças de carbeto de silício preparadas por gelcasting, também permitiu a obtenção de componentes de formatos complexos com bom acabamento, bordas afiadas e com uma usinagem fácil sem defeitos acrescentados. A Figura 2.28 ilustra exemplos de duas peças de formato complexos obtidas (LIU et al., 2010).

No trabalho de Lee e Lee (2004), a usinagem em verde de alumina com ligante epóxi foi aplicada na obtenção de microfuros com uma ferramenta revestida de pó de diamante (Figura 2.23), utilizando uma retificadora CNC de alta precisão equipada com um cabeçote pneumático de alta rotação. Exemplo dos furos obtidos e suas dimensões são mostrados na Figura 2.29.

Um disco bruto em titanato zirconato piezelétrico, com ligante termoplástico, foi usinado em verde em uma mini máquina CNC utilizando uma fresa de carboneto de tungstênio, buscando-se por estator cerâmico no formato de moinho de vento para um motor ultrassônico. A Figura 2.30 mostra o estator já usinado e o mesmo em sua bancada de teste (YOON et al., 2007). 


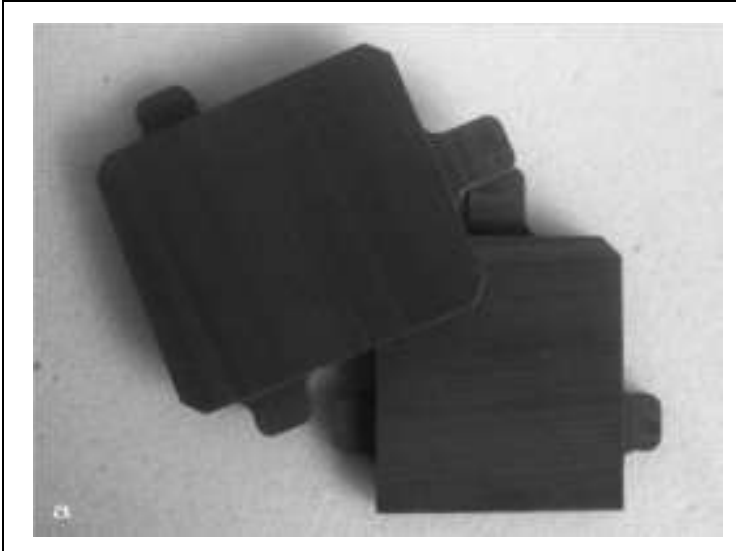

(a)

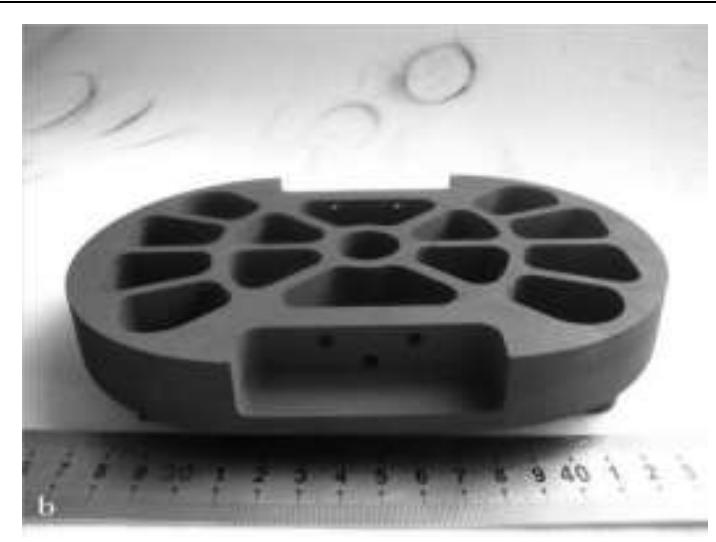

(b)

Figura 2.28 - Peças usinadas em verde, produto (a) e (b). (LIU et al., 2010, adaptado).

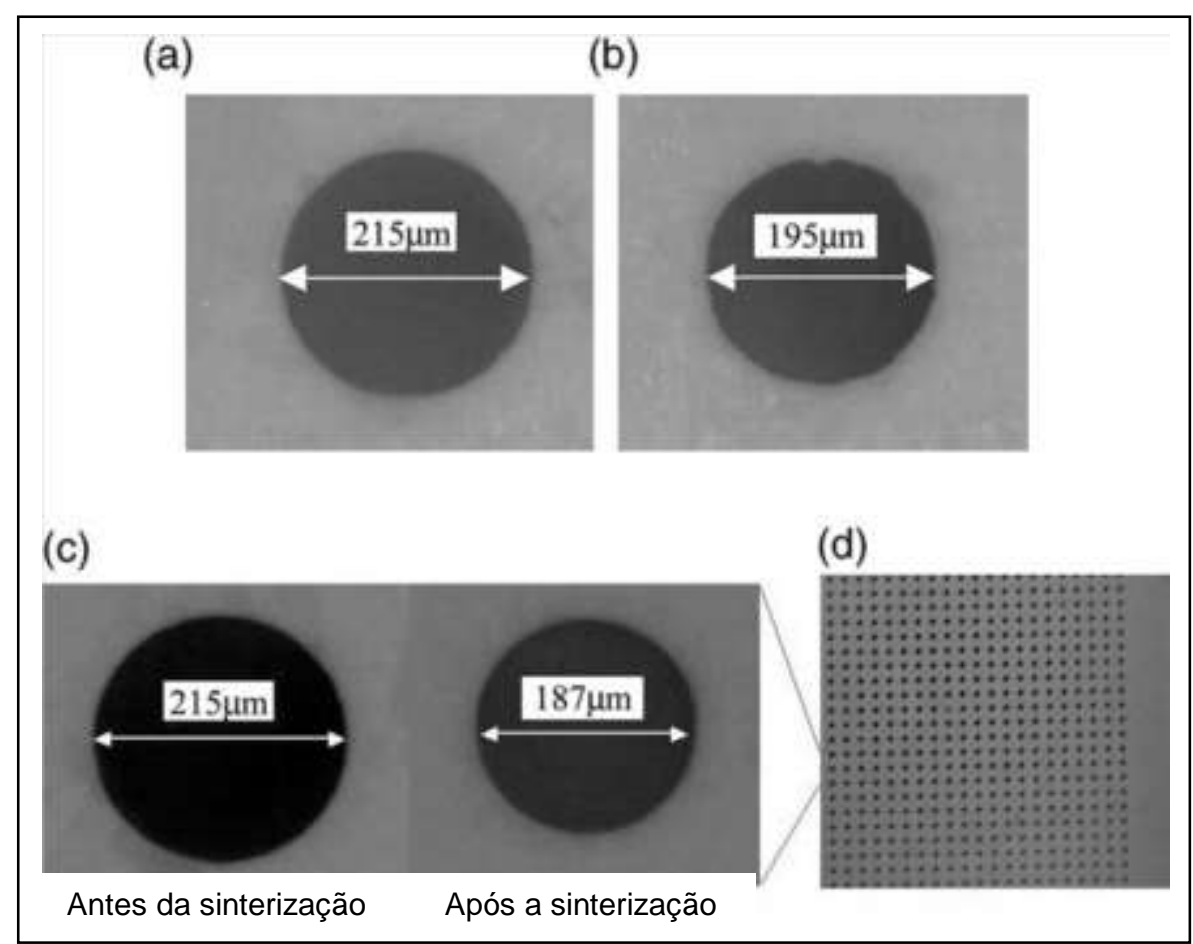

Figura 2.29 - Diâmetros dos micros furos em verde e sinterizado: (a) diâmetro de entrada do micro furo; (b) diâmetro de saída do micro furo; (c) diâmetro do micro furo antes e após a sinterização; (d) placa de microcanais (LEE e LEE, 2004).

Outra aplicação da usinagem em verde que vem aumentando é na área da odontologia, sendo aplicada na fabricação de próteses tais como as coroas dentárias. A Figura 2.31 mostra exemplos de coroas que foram usinadas em verde e posteriormente sinterizadas, apresentando precisão micrométrica (RITZHAUPTKLEISSL et al., 2006). 
Também em aplicação dentária, Su, Dhara e Wang (2008), aplicaram a usinagem em verde na obtenção de molar dentário em zircônia, como pode ser observado na Figura 2.32, utilizando uma fresadora CNC (MDX 650) da Roland DG Ltda.

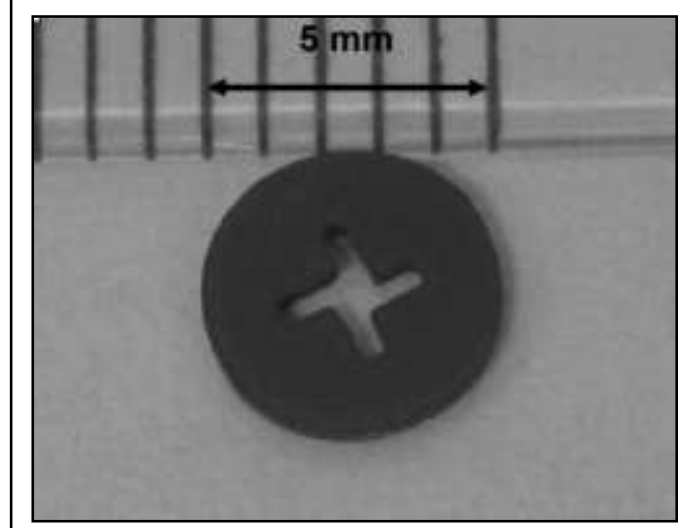

(a)

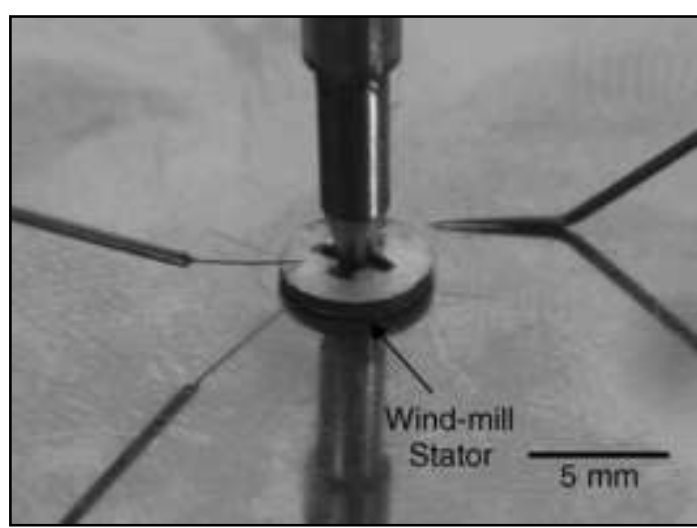

(b)

Figura 2.30 - Motor ultrassônico: (a) fotografia ótica do estator em formato de moinho de vento fabricado pela usinagem em verde termoplástica; (b) fotografia ótica da montagem experimental do estator tipo moinho de vento (YOON et al., 2007, adaptado).

Na Figura 2.15 é mostrada a representação de uma peça de simetria com paredes finas, que foi utilizada para o desenvolvimento da seleção da geometria da ferramenta e do procedimento de usinagem a ser aplicado na usinagem em verde. $O$ material selecionado para o estudo foi o carbeto de silício. Um modelo em CAD para a seleção da geometria da ferramenta foi desenvolvido para permitir a seleção do trajeto de corte. O procedimento que foi utilizado para otimizar a usinagem em verde do compactado de carbeto de silício foi como se segue (EL- WARDANY et al., 2009):

- definir o sistema de ligante para alcançar razoável resistência mecânica em verde da peça;

- definir a geometria ótima da ferramenta para produzir superfícies usinadas em verde livre de trincas;

- realizar experiências para definir a profundidade axial máxima sem gerar lascamento na entrada e saída da ferramenta;

- utilizar mecanismo de modelamento para direcionar o processo de geração do trajeto de corte para prevenir o lascamento de borda. 


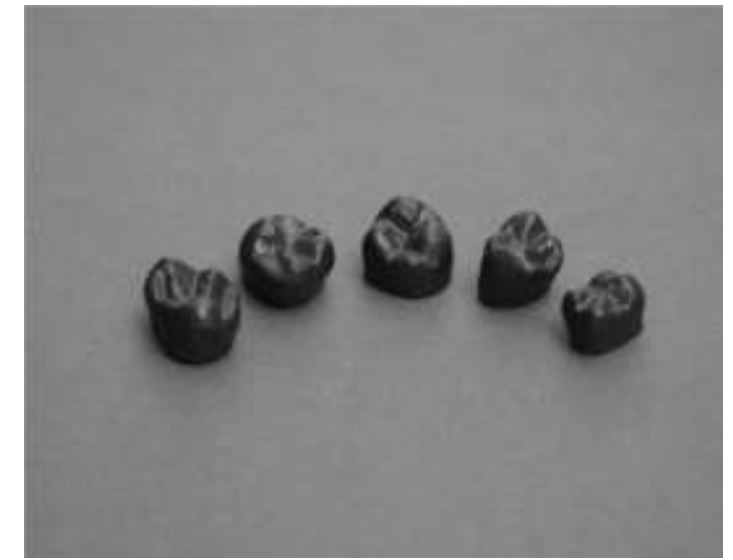

(a)

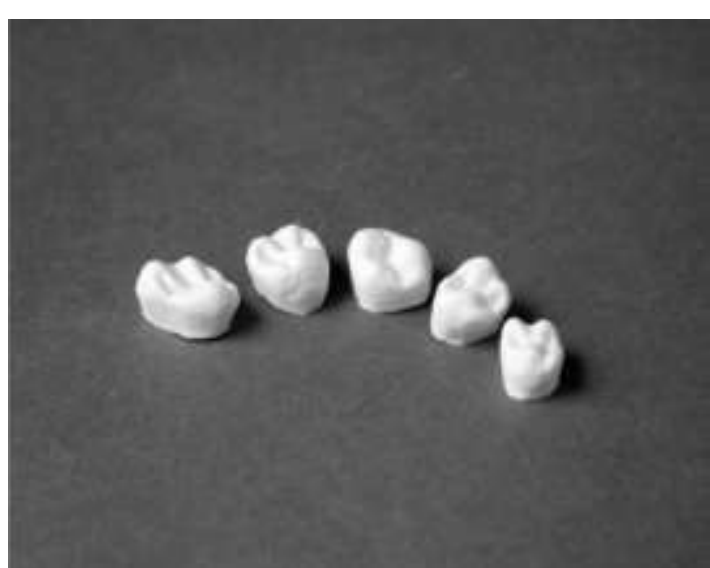

(b)

Figura 2.31 - Coroas dentaria cerâmicas usinadas em verde (a) e sinterizadas (b), apresentando precisão micrométrica (RITZHAUPT-KLEISSL et al., 2006, adaptado).

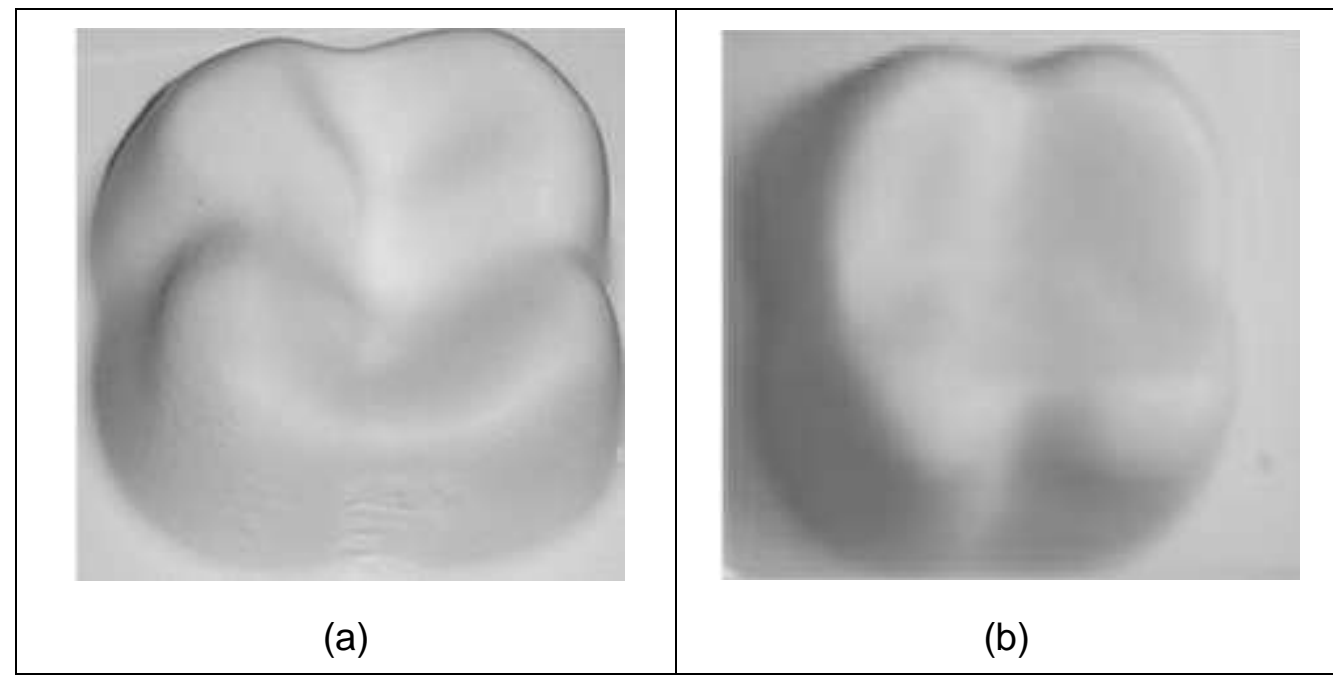

Figura 2.32 - (a) usinagem em verde CNC e (b) modelo de um molar dentário de cerâmica sinterizada (SU, DHARA e WANG, 2008, adaptado).

\subsection{Acabamento}

Como a rugosidade final do compactado sinterizado depende da rugosidade inicial, introduzida durante a usinagem em verde desse compactado, tentativas devem ser feitas para estudar a variação no parâmetro de rugosidade em várias temperaturas de sinterização. Isso é importante para obter compactados com baixa rugosidade, microestrutura homogênea e crescimento de grão inibido (MANPI et al., 2011).

No trabalho de Bukvic et al. 2012, foi demonstrada a influência da rugosidade em verde nas peças sinterizadas. Tarugos de alumina spray-dried com ligante PVAl, 
compactados uniaxialmente, foram usinados em verde com a remoção de diferentes sobremateriais, demonstrando a influência do desgaste de flanco máximo (VBmax), atingido na ferramenta, em função de cada valor de sobrematerial removido (Figura 2.33). Pode ser observado que com o aumento do desgaste de flanco máximo houve o aumento da rugosidade da peça, porém, foi observada uma redução da rugosidade após a sinterização, independentemente do valor da rugosidade em verde.

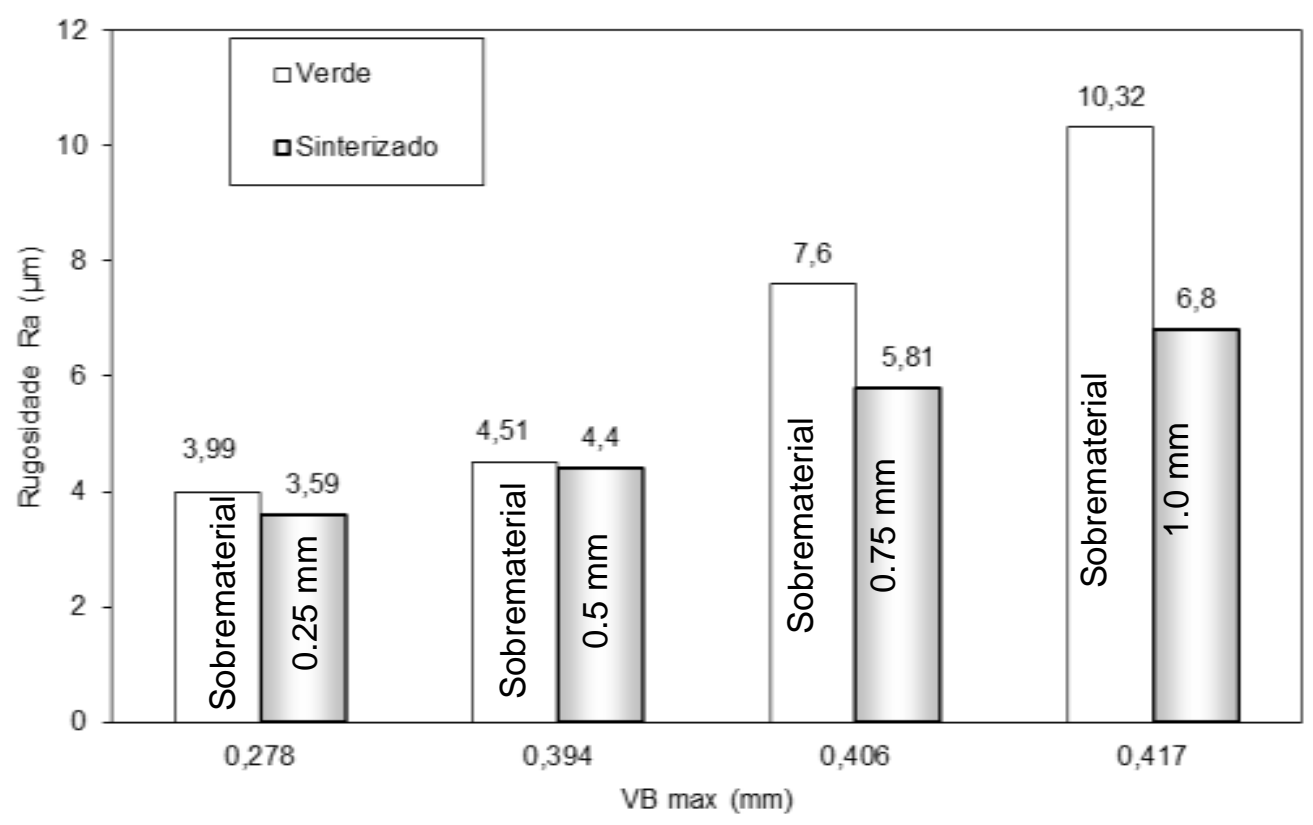

Figura 2.33 - Rugosidade das peças em verde e depois da sinterizaçao no final de cada sobrematerial (BUKVIC et al., 2012).

Em superfícies funcionais, com estreita tolerância dimensional de forma, bem como a fina rugosidade superficial, torna-se indispensável a operação final de usinagem após a sinterização, pois na etapa de sinterização a retração diferencial causa desvio dimensional. Retificação de acabamento ou uma operação de polimento, mesmo com a otimização da tecnologia do near-net-shape se faz necessária (KLOCKE, GERENT e SCHIPPERS, 1997). 


\section{MATERIAIS E MÉTODOS}

A construção de uma matriz de decisão para estratégia de usinagem em verde exigiu a manufatura de modelos padrões, como corpos cilíndricos, barras e um corpo com furos que foram usinados em verde a partir de blanks compactados.

No processamento dos cilindros foi variada a pressão de compactação, realizadas medidas de tensão de ruptura a flexão (em verde e sinterizados); medidas de torque de usinagem e análise da rugosidade. Por meio destes foram validado os ligantes; pelas barras foram avaliados os parâmetros de usinagem, a força de corte, os lascamentos e o empastamento das ferramentas; pelos furos a técnica do processo de usinagem aplicada para obtenção do mesmo.

A alumina foi selecionada para este estudo devido suas características e propriedades reconhecidas universalmente.

A validação da matriz de decisão para estratégia de usinagem em verde foi realizada pela aplicação na manufatura free-form (formato com eixo de revolução assimétrico) de um implante dentário conceitual.

\subsection{Estratégia de usinagem em verde}

$\mathrm{Na}$ produção de uma peça qualquer por usinagem em verde diversos aspectos do processo de fabricação devem ser considerados. Questionamentos sobre o processo de usinagem, a máquina, os parâmetros de usinagem, a ferramenta e o ligante da cerâmica em verde orientou a busca por uma matriz de decisão para estratégia de usinagem em verde.

Essa matriz tem por objetivo auxiliar, de forma estratégica, a escolha de toda a cadeia do processo de fabricação de uma peça cerâmica qualquer pela usinagem em verde. Desta forma, a partir do desenho de uma peça desejada, selecionar (com o auxilio da matriz de decisão) qual o caminho que deve ser traçado para a possível rota de fabricação e, ainda, com acabamento e resistência mecânica otimizados.

\subsubsection{Matriz de decisão}

Para serem utilizados como dados de entrada na matriz de decisão, itens como o formato da peça, tipo de ferramenta, tipo de máquina e o tipo de ligante foram tabelados para quantificar suas variedades. 


\subsubsection{Formato da peça}

Uma família básica de formato de peças é proposta na Tabela 3.1. Cada formato está relacionado em função dos diferentes processos de usinagem que podem ser aplicados na sua obtenção. Sendo esses os formatos característicos que podem ser observados em qualquer tipo de peça. Uma peça também pode apresentar dois ou mais formatos dos listados na tabela.

Entende-se por peças com formato free-form, aquelas que não possuem simetria, tais como: superfície em forma de relevo ou curva; e eixo de revolução assimétrico ou curvo. 
Tabela 3.1 - Família básica de formatos de peças em função do processo de usinagem.

\begin{tabular}{|c|c|c|}
\hline Formato & $\begin{array}{c}\text { Desenho } \\
\text { Esquemático }\end{array}$ & Processo de Usinagem \\
\hline Cilíndrico & & $\begin{array}{l}\text { Retificação cilíndrica (interno ou externo) } \\
\text { Torneamento cilíndrico (interno ou externo) }\end{array}$ \\
\hline $\begin{array}{l}\text { Revolução free- } \\
\text { form }\end{array}$ & & $\begin{array}{c}\text { Retificação cilíndrica curvilínea } \\
\text { Retificação de perfil } \\
\text { Torneamento curvilíneo } \\
\text { Perfilamento (torneamento) }\end{array}$ \\
\hline $\begin{array}{l}\text { Retangular ou } \\
\text { quadrado }\end{array}$ & & $\begin{array}{l}\text { Retificação tangencial plana } \\
\text { Retificação frontal } \\
\text { Fresamento cilíndrico tangencial } \\
\text { Fresamento frontal }\end{array}$ \\
\hline Furo & & $\begin{array}{l}\text { Furação } \\
\begin{array}{l}\text { Retificação frontal (diâmetro do furo igual a da } \\
\text { ferramenta) }\end{array} \\
\begin{array}{l}\text { Retificação frontal incremental (diâmetro do furo } \\
\text { maior do que da ferramenta) }\end{array} \\
\text { Fresamento frontal (diâmetro do furo igual a da } \\
\text { ferramenta) } \\
\begin{array}{l}\text { Fresamento frontal incremental (diâmetro do furo } \\
\text { maior do que da ferramenta) }\end{array}\end{array}$ \\
\hline Esférico & & $\begin{array}{c}\text { Retificação cilíndrica curvilínea } \\
\text { Retificação de perfil } \\
\text { Torneamento curvilíneo } \\
\text { Perfilamento (torneamento) }\end{array}$ \\
\hline Free-form & & $\begin{array}{l}\text { Retificação frontal } \\
\text { Fresamento frontal }\end{array}$ \\
\hline $\begin{array}{l}\text { Aleta de } \\
\text { revolução free- } \\
\text { form }\end{array}$ & - & $\begin{array}{l}\text { Retificação tangencial de mergulho } \\
\text { Sangramento (torneamento) }\end{array}$ \\
\hline Aleta free-form & $\square \triangle \curvearrowright$ & $\begin{array}{c}\text { Retificação tangencial de mergulho } \\
\text { Retificação frontal } \\
\text { Fresamento frontal }\end{array}$ \\
\hline
\end{tabular}




\subsubsection{Máquinas}

A usinagem em verde, por apresentar baixo esforço de corte, permite 0 emprego de máquinas de usinagem ordinárias (convencionais), seja ela um torno, uma fresadora, uma retificadora, etc. Isso, desde que se protejam as partes funcionais da máquina (guias de movimentação dos eixos, fusos, rolamentos) para evitar o contato com as partículas cerâmicas abrasivas desprendidas na usinagem (cavacos). Na Tabela 3.2 estão listados os principais tipos de máquinas em função do tipo de comando que podem apresentar.

Em destaque estão os centros de usinagem que, por serem máquinas de comando CNC e flexíveis, permitem realizar operações de torneamento, fresamento, retificação e furação, sendo consideradas máquinas ideais na execução de peças free-form, pois permitem que suas ferramentas alcancem todos os detalhes das peças. A quantidade de graus de liberdade da máquina é necessária em função da complexidade da peça, sendo que para baixa complexidade são necessários 3 graus; para média complexidade, 4 graus; e alta complexidade, 5 graus.

Tabela 3.2 - Tipos de máquinas em função do tipo de comando.

\begin{tabular}{|c|c|}
\hline Tipo de máquina & Comando \\
\hline Torno & $\begin{array}{c}\text { Manual } \\
\text { CNC }\end{array}$ \\
\hline Fresadora & $\begin{array}{c}\text { Manual } \\
\text { CNC }\end{array}$ \\
\hline Retificadora & $\begin{array}{c}\text { Manual } \\
\text { CNC }\end{array}$ \\
\hline Furadeira & $\begin{array}{c}\text { Manual } \\
\text { CNC }\end{array}$ \\
\hline Centro de usinagem com 3 graus de liberdade & CNC \\
\hline Centro de usinagem com 4 graus de liberdade & CNC \\
\hline Centro de usinagem com 5 graus de liberdade & CNC \\
\hline
\end{tabular}

\subsubsection{Ferramentas}

Diferentes tipos de ferramentas podem ser utilizados nos diferentes processos de fabricação, para a usinagem de uma peça conforme o formato desejado. $\mathrm{Na}$ Tabela 3.3, são propostas algumas ferramentas básicas que podem ser utilizadas 
em função do tipo de material que podem ser fabricadas e da máquina a ser empregada.

Embora qualquer ferramenta convencional possa ser aplicada, em ferramentas de metal duro ou metal duro revestido, ocorrerá um desgaste prematuro da aresta cortante por conta da característica abrasiva do pó cerâmico. Isso ocasionará a elevação da força de corte, resultando no aumento da rugosidade na superfície da peça, lascamentos de borda, trincas superficiais/subsuperficiais e perda de resistência mecânica da peça. Neste caso, ferramentas com diamantes, CBN, alumina eletrofundida e cerâmicas, são as melhores opções em relação à vida de ferramenta, por ambas serem materiais extremamente duros, e com isso apresentar um menor desgaste.

Ponta montada cilíndrica com ponta de face plana, é mais adequada a peças de geometria simples com faces planas e cantos vivos, já pontas montadas que possuam ponta esférica ou ponta em forma de calota esférica, são mais adequadas a peças que possuem cantos arredondados e superfície free-form devido às curvas que a superfície possui.

A ferramenta ponta montada é fabricada com grãos abrasivos, que são fixados a uma haste cilíndrica por processo de eletrodeposição metálica ou mesmo por resina. Pode ser produzida em uma grande variedade de formatos e dimensões, utilizando grãos abrasivos de diamante, CBN ou alumina eletrofundida de diferentes granulometrias. 
Tabela 3.3 - Ferramentas básicas em função do tipo de material e da máquina.

\begin{tabular}{|c|c|c|c|}
\hline Ferramenta & $\begin{array}{c}\text { Desenho } \\
\text { Esquemático }\end{array}$ & Material & Tipo de Máquina \\
\hline \multicolumn{4}{|l|}{ Pontas Montadas } \\
\hline $\begin{array}{c}\text { Ponta esférica } \\
\text { Cilíndrica com ponta de face } \\
\text { plana } \\
\text { Cilíndrica com ponta em } \\
\text { forma de calota esférica } \\
\text { Cônica com ponta de face } \\
\text { plana } \\
\text { Cônica com ponta em forma } \\
\text { de calota esférica }\end{array}$ & & $\begin{array}{c}\text { Diamante } \\
\text { CBN } \\
\text { Alumina eletro- } \\
\text { fundida }\end{array}$ & $\begin{array}{l}\text { Centro de } \\
\text { usinagem }(3,4 \text { ou } \\
5 \text { graus de } \\
\text { liberdade })\end{array}$ \\
\hline \multicolumn{4}{|l|}{ Rebolos } \\
\hline $\begin{array}{c}\text { Rebolo } \\
\text { Disco (peça free-form) }\end{array}$ & & $\begin{array}{c}\text { Diamante } \\
\text { CBN } \\
\text { Alumina eletro- } \\
\text { fundida }\end{array}$ & Retificadora \\
\hline \multicolumn{4}{|l|}{ Ponta única } \\
\hline Pastilha & & $\begin{array}{l}\text { Diamante } \\
\quad \text { CBN } \\
\text { Metal duro } \\
\text { Metal duro } \\
\text { revestido }\end{array}$ & Torno \\
\hline \multicolumn{4}{|l|}{ Pontas múltiplas } \\
\hline $\begin{array}{l}\text { Fresa } \\
\text { Broca }\end{array}$ & 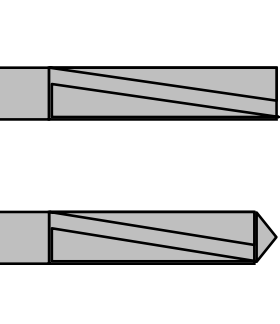 & $\begin{array}{l}\text { Metal duro } \\
\text { Metal duro } \\
\text { revestido }\end{array}$ & $\begin{array}{c}\text { Centro de } \\
\text { usinagem }(3,4 \text { ou } \\
5 \text { graus de } \\
\text { liberdade }) \\
\text { Fresadora } \\
\text { Furadeira }\end{array}$ \\
\hline
\end{tabular}




\subsubsection{Ligante}

O ligante tem importância fundamental na resistência mecânica em verde da peça, com isso, deve ser considerado na matriz de decisão para estratégia de usinagem em verde. A Tabela 3.4, mostra os ligantes mais utilizados na obtenção de pós para prensagem e usinagem em verde em função do seu meio líquido, sendo que cada um possui características distintas.

Tabela 3.4 - Tipos de ligantes.

\begin{tabular}{|c|c|}
\hline Ligante & Meio líquido \\
\hline PVAl & Água destilada \\
\hline PVB & Álcool Isopropílico \\
\hline B-1022 (Acrílico) & Água destilada \\
\hline B-1007 (Acrílico) & Água destilada \\
\hline
\end{tabular}

\subsubsection{Matriz de decisão para estratégia de usinagem em verde}

A seguir (Figura 3.1), segue a proposta da matriz de decisão para estratégia de usinagem em verde, contendo todos os itens relacionados a uma cadeia de processos de fabricação possíveis para a produção de uma peça. A seleção dos itens dependerá da possibilidade de aplicação de cada item na obtenção do formato esperado da peça. Neste ponto é feito um questionamento para auxiliar na tomada de decisão.

Sua aplicação e estruturação serão demonstradas, nos próximos tópicos deste trabalho, no estudo de caso de usinagem em verde de peças com um formato pré-determinado. A seleção dos itens se iniciará a partir do formato inicial predominante da peça a ser produzida. 


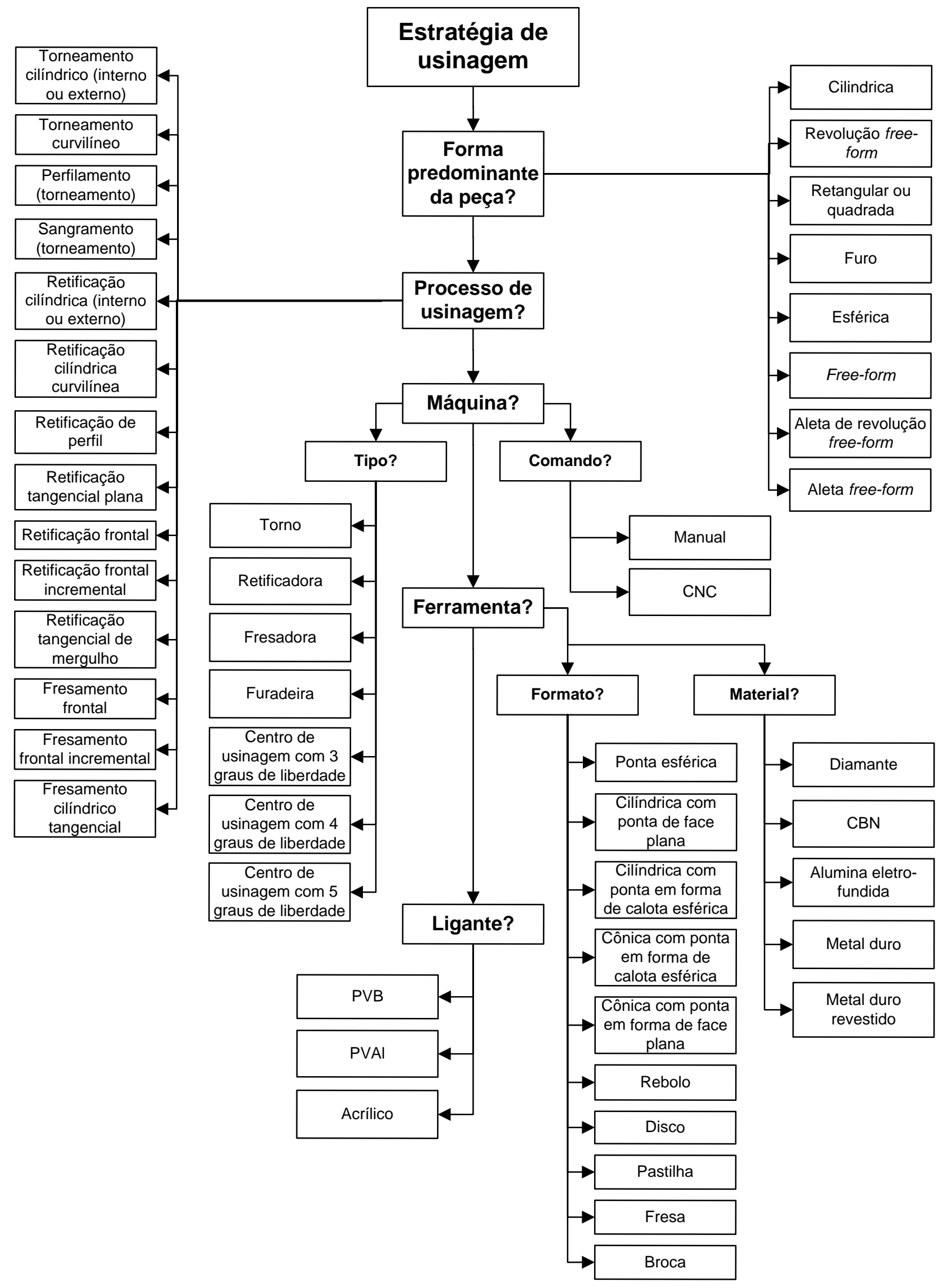

Figura 3.1 - Matriz de decisão para estratégia de usinagem em verde. 


\subsection{Estudo de caso de usinagem em verde}

Neste tópico, foi feita a estruturação da matriz de decisão para estratégia de usinagem em verde para quatro peças diferentes, sendo a primeira em formato de barra de perfil retangular, a segunda em formato cilíndrico, a terceira também de formato de barra de perfil retangular, porém, para análise de sua superfície funcional; e uma quarta com furos, para análise do processo de fabricação aplicado na execução da furação. Para a obtenção dessas peças foi aplicada a retificação frontal, a retificação cilíndrica externa, a retificação tangencial plana e a retificação frontal incremental, respectivamente.

Ênfase foi dada a aplicação do processo de retificação (o que caracterizou a utilização de ferramentas de arrestas não definidas como pontas montadas e rebolo), uma vez que ela se enquadra na obtenção de todos os formatos de peças descritos na Tabela 3.1, e também por poder permitir um melhor acabamento (menor rugosidade) dentre os outros processos de fabricação citados nessa mesma tabela.

\subsubsection{Estratégia de usinagem em verde na fabricação de uma barra com perfil retangular (Ensaio Preliminar)}

Para a obtenção de um corpo-de-prova em formato de barra com perfil retangular deve-se relacionar a forma do objeto em relação ao tipo de processo que pode ser aplicado a ele (Tabela 3.1) e, neste caso, se tem a retificação tangencial plana, a retificação frontal, o fresamento cilíndrico tangencial e o fresamento frontal como opções. Neste ponto, a escolha pelo fresamento ou a retificação, se dá em relação ao tipo de acabamento superficial obtido por cada processo. A retificação pode proporcionar menor rugosidade superficial comparado com o fresamento.

Para o efeito do estudo, o corpo-de-prova necessitará do melhor acabamento possível alcançado pela usinagem, neste caso, fica a escolha pela retificação, que poderá ser realizada por uma retificadora ou um centro de usinagem, como é demonstrado na Tabela 3.2. A peça também tem a necessidade de precisão dimensional, que é melhor obtida por máquinas de controle CNC (Tabela 3.2), uma vez que não haverá a intervenção do homem nos posicionamentos da ferramenta na execução da usinagem. 
A escolha por uma retificadora $\mathrm{CNC}$ ou por um centro de usinagem se deve à questões físicas de cada máquina. O corpo-de-prova deverá ser fabricado a partir de um bloco conformado em verde, que permitirá a obtenção de vários corpos-de-prova por meio de seu seccionamento. Nesse caso, a utilização de uma retificadora CNC, não é a melhor opção, pois, sua construção permite apenas dar acabamento nas faces das peças. $O$ centro de usinagem permite aplicar a operação de retificação utilizando a ferramenta ponta montada, gerando o acabamento necessário, e cortando o bloco ao mesmo tempo, sendo assim a opção escolhida.

Devido ao corpo-de-prova possuir formato retangular, com faces perpendiculares e paralelas umas às outras, não se exigirá um centro de usinagem com mais do que 3 graus de liberdade para a sua produção. $O$ processo de usinagem chamado de retificação frontal (Tabela 3.1) será o requerido para a fabricação, e permitirá o uso da ferramenta ponta montada. A forma da ferramenta, por sua vez, não necessitará ser complexa, cabendo uma de formato cilíndrico com ponta de face plana (Tabela 3.3) ser a requerida para a usinagem.

A escolha do melhor material da ferramenta (Tabela 3.3) e o tipo de ligante (Tabela 3.4) ficarão a cargo do estudo desses corpos-de-prova usinados sob diferentes parâmetros de corte, utilizando diferentes ligantes em sua composição e diferentes materiais da ferramenta. As barras obtidas foram sinterizadas e submetidas ao ensaio de ruptura à flexão e foram analisadas pela medida da rugosidade de suas superfícies usinadas. Os resultados indicarão qual a melhor combinação de ligante, material da ferramenta e parâmetros de corte utilizados.

Com a escolha destas variáveis é possível obter a matriz de decisão para estratégia de usinagem em verde parcial para a produção de corpos-de-prova em formato de barra de perfil retangular (Figura 3.2). Sua resolução foi finalizada no tópico resultados e discussão, a qual recebeu as informações da análise do material da ferramenta, do tipo de ligante e dos parâmetros de corte, que foram necessárias para a obtenção final da peça. 


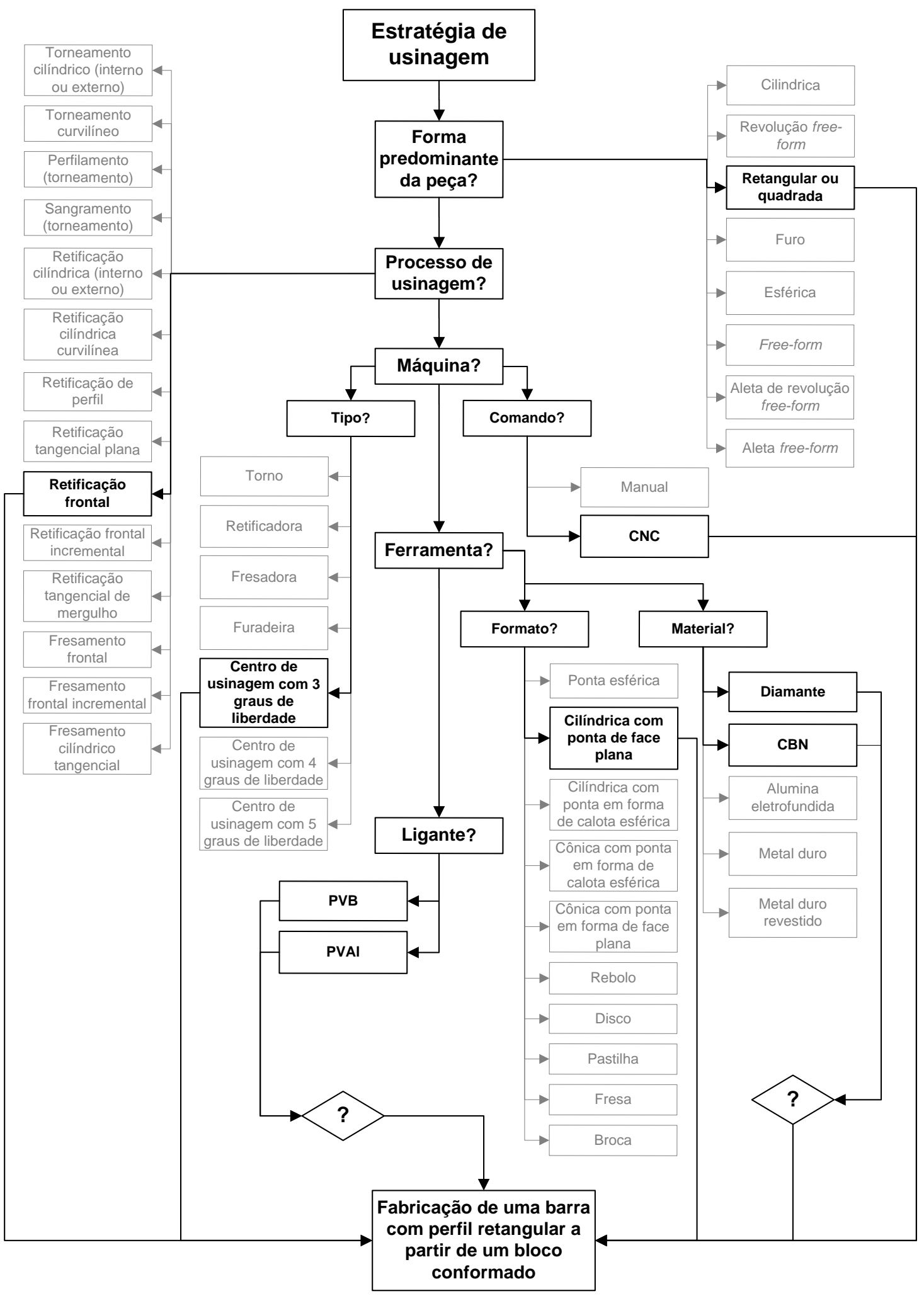

Figura 3.2 - Matriz de decisão para estratégia de usinagem em verde parcial na fabricação de uma barra com perfil retangular a partir de um bloco conformado. 


\subsubsection{Preparação dos corpos de prova}

Para obter os corpos-de-prova em formato de barras foram utilizados blanks

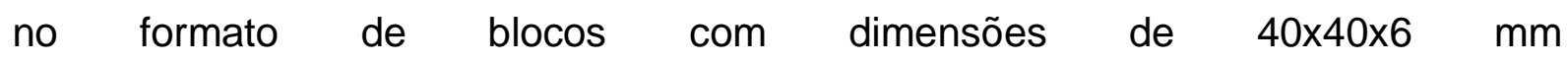
(comprimento/largura/espessura), prensados uniaxialmente à $80 \mathrm{MPa}$ seguido de prensagem isostática a $100 \mathrm{MPa}$. E esses foram usinados em verde utilizando a matriz de decisão para estratégia de usinagem em verde. Os corpos foram tratados termicamente à $100 \stackrel{\circ}{ } \mathrm{C}$ por 12 horas, para homogeneizar e aliviar as tensões provenientes da prensagem. Os blocos foram aderidos, com cianoacrilato, na superfície de uma base de gesso, por uma de suas superfícies $(40 \times 40 \mathrm{~mm})$, para permitir a usinagem.

\subsubsection{Matéria prima e manufatura}

Como matéria prima foi empregada a Alumina Calcinada A1000-SG, (Almatis, Inc.) com diâmetro médio equivalente de partícula de 0,4 $\mu \mathrm{m}$, área superficial de 7,7 $\mathrm{mm}^{2} / \mathrm{g}$, $\rho_{\text {real: }}: 3,99 \mathrm{~g} / \mathrm{cm}^{3}$. Como ligante foi utilizado o PVAl (2\% em peso) juntamente com o poliacrilato de amônia (dispersal 130) (1\% em peso) em meio aquoso à 68 vol\% e o PVB (2\% em peso) em meio alcoólico (álcool Isopropílico) à 68 vol\% os quais foram misturados em moagem de bolas por 12 horas e, posteriormente, secos e granulados manualmente. As formulações foram denominadas de acordo com a Tabela 3.5. Foi decidido pela uniformização do percentual em peso dos ligantes aplicados na formulação cerâmica.

Tabela 3.5 - Denominação das formulações.

\begin{tabular}{|c|c|c|c|}
\hline Material & Ligante & Defloculante & Meio liquido \\
\hline A & PVAL & Poliacrilato de Amônio & Água destilada \\
\hline B & PVB & PVB & Álcool Isopropílico \\
\hline
\end{tabular}

\subsubsection{Seleção da ferramenta}

Duas ferramentas do formato descrito na matriz de decisão (pontas montada de formato cilíndrico com ponta de face plana) foram aplicadas utilizando, a primeira, abrasivo de diamante e, a segunda, abrasivo de CBN, ambas utilizando 
eletrodeposição metálica de níquel (ligante metálico) para a fixação dos grãos abrasivos. As dimensões das ferramentas escolhidas para o ensaio foram de $2 \times 6$ $\mathrm{mm}$ (diâmetro/comprimento) com abrasivo de granulometria \#80 mesh, tanto para o diamante quanto para o CBN. A descrição da ferramenta de diamante gerada pelo fabricante foi D PMD 020 D 181 e da de CBN foi B PMD 020 B 181, ambas fabricadas pela empresa Master Diamond Ferramentas Ltda.

A opção pelo diamante e o CBN se deve a característica de alta dureza apresentada por estes abrasivos, o que reflete na vida da ferramenta. O diamante é o material mais duro encontrado na natureza, e o CBN, um material artificial com sua dureza logo abaixo do diamante. Arestas "afiadas" são indispensáveis na usinagem e isto se deve a natureza do grão abrasivo, ou seja, se o grão é natural, artificial ou se foi fundido e fraturado como o caso da alumina eletrofundida. Por isso, foi feita a escolha do CBN como uma segunda opção de material para a ferramenta.

Com o intuito de analisar a influência do formato dos grãos abrasivos utilizados nas ferramentas, quantidades livres desses abrasivos foram analisados por microscopia eletrônica de varredura (MEV). As imagens obtidas foram apresentadas na Figura 3.3 e demonstraram semelhança entre os abrasivos de diamante e CBN, sendo observados grãos dos mais diversos formatos, porém, os grãos de CBN demonstraram uma superfície mais áspera e a predominância de grãos mais pontiagudos em comparação com os grãos de diamante. Já os grãos de alumina eletrofundida tem a predominância do formato de lascas com arestas agudas e superfície com fratura do tipo conchoidal. 

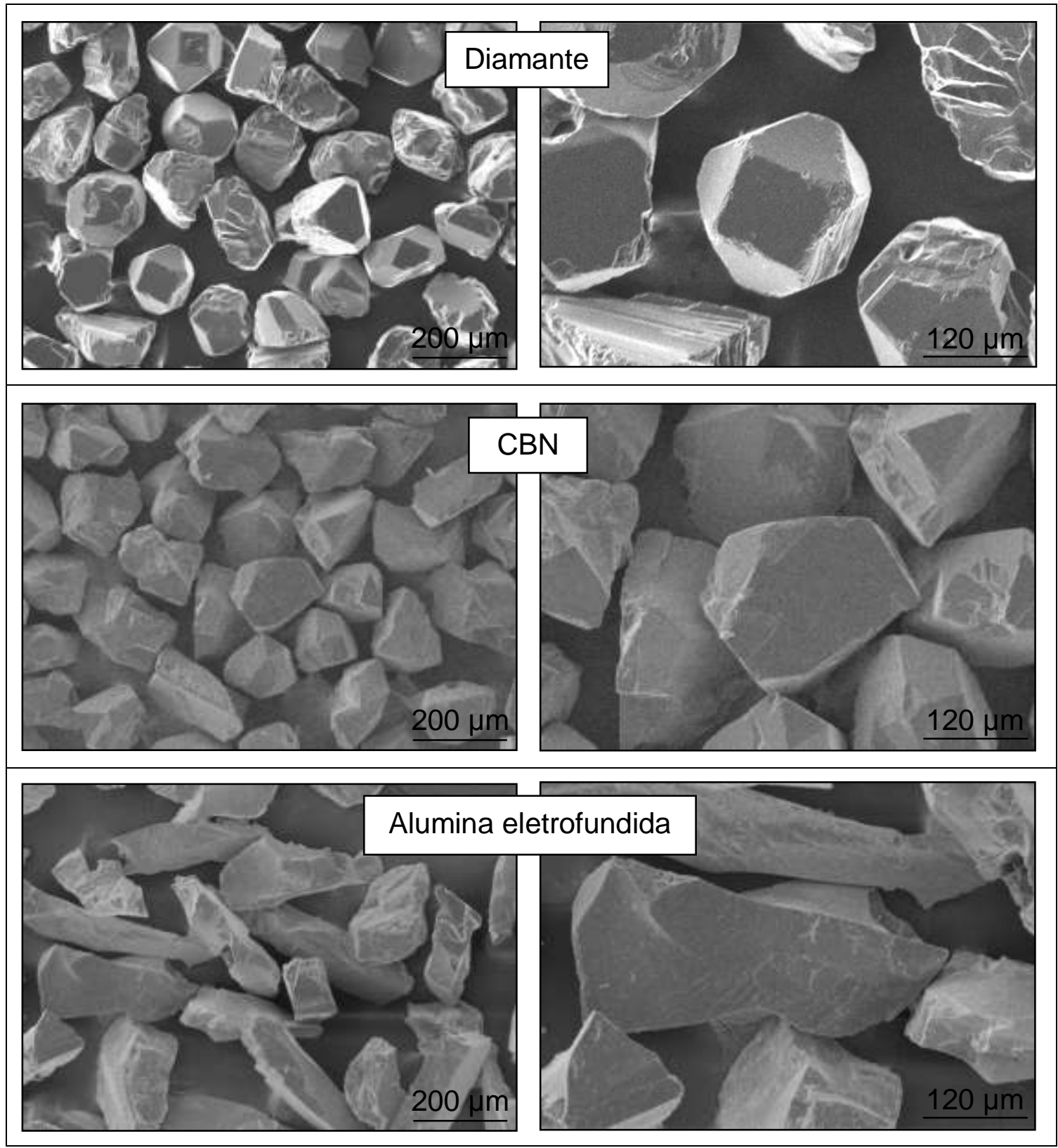

Figura 3.3 - MEV dos abrasivos utilizados nas ferramentas.

\subsubsection{Planejamento e ensaios de usinagem}

Os experimentos de usinagem seguiram o planejamento apresentado na Tabela 3.6. Foi empregada um centro de usinagem de 3 graus de liberdade, como $o$ especificado na matriz de decisão, equipado com um spindle (Precise) da Chapman Laboratory Ltda., de rolamentos esféricos de precisão com rotação de 36.500 rpm e $500 \mathrm{~W}$ de potência, que gerou velocidade de corte $\left(\mathrm{v}_{\mathrm{c}}\right)$ de $3,82 \mathrm{~m} / \mathrm{s}(\varnothing 2 \mathrm{~mm})$.

A montagem da bancada de ensaio é mostrada na Figura 3.5, onde se observa o centro de usinagem a esquerda junto a seu módulo de controle e o 
computador a direita. Na Figura 3.5 (a) é apresentado o desenho do planejamento da usinagem e na Figura 3.5 (b) a execução da usinagem para a obtenção das peças.

Tabela 3.6 - Planejamento experimental.

\begin{tabular}{|c|c|c|c|c|c|}
\hline $\begin{array}{l}\stackrel{0}{刃} \\
\stackrel{D}{5} \\
\text { w }\end{array}$ & 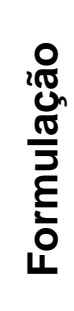 & 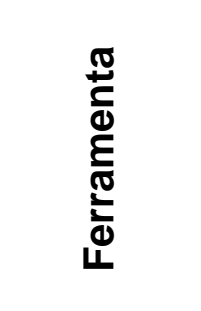 & 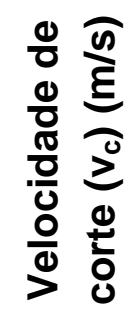 & 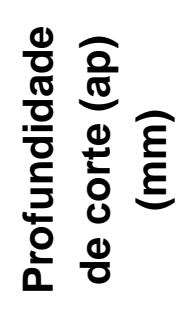 & 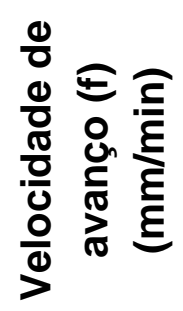 \\
\hline AD-5-100 & $\Lambda$ & \multirow{4}{*}{ Diamante } & \multirow{6}{*}{3,82} & \multirow{6}{*}{0,5} & 100 \\
\hline AD-5-50 & $A$ & & & & 50 \\
\hline BD-5-100 & \multirow{4}{*}{ B } & & & & 100 \\
\hline BD1-5-50 & & & & & 50 \\
\hline BC-5-100 & & \multirow{2}{*}{ CBN } & & & 100 \\
\hline BC-5-50 & & & & & 50 \\
\hline
\end{tabular}

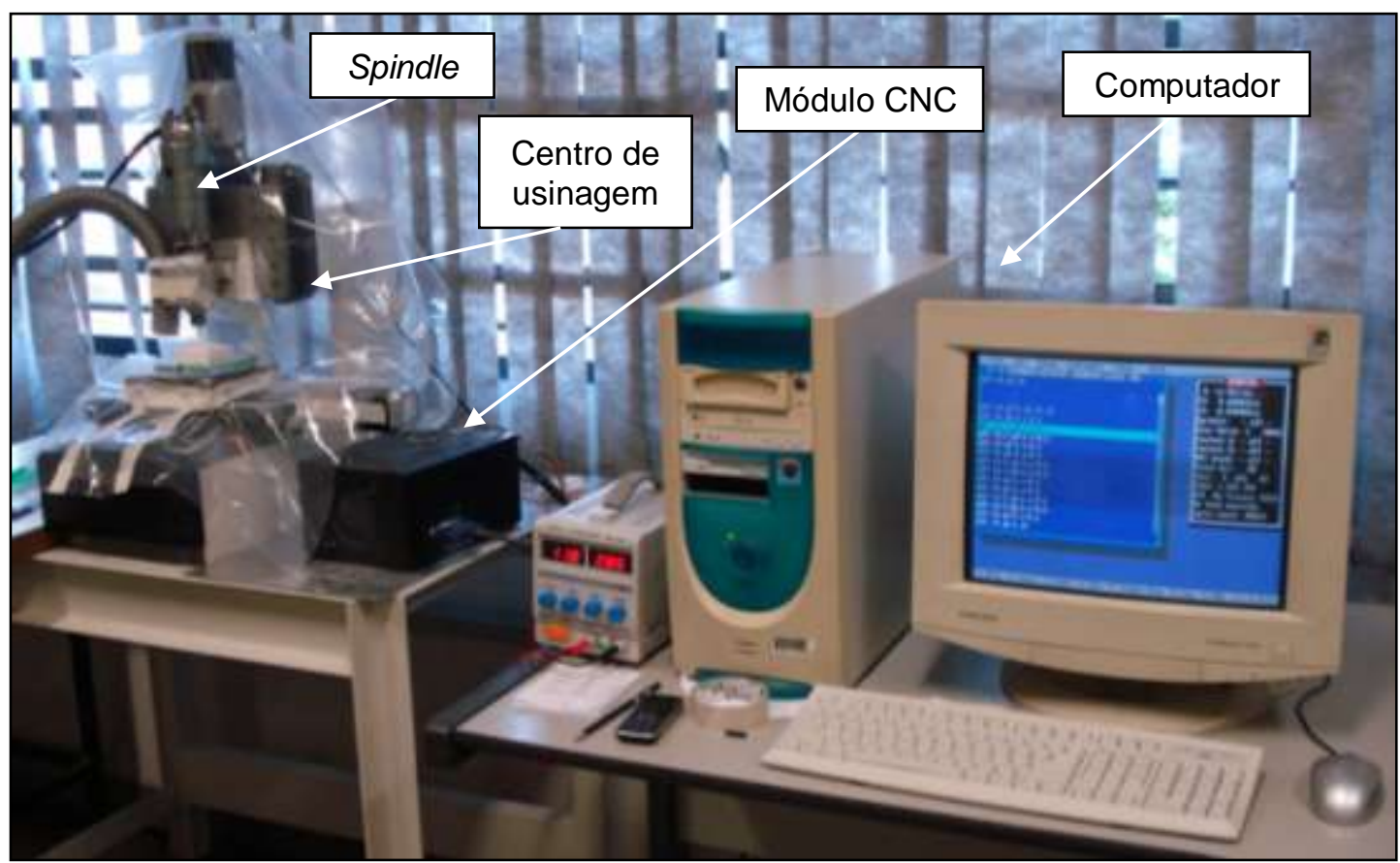

Figura 3.4 - Banco de ensaio para usinagem de barras de perfil retangular. 


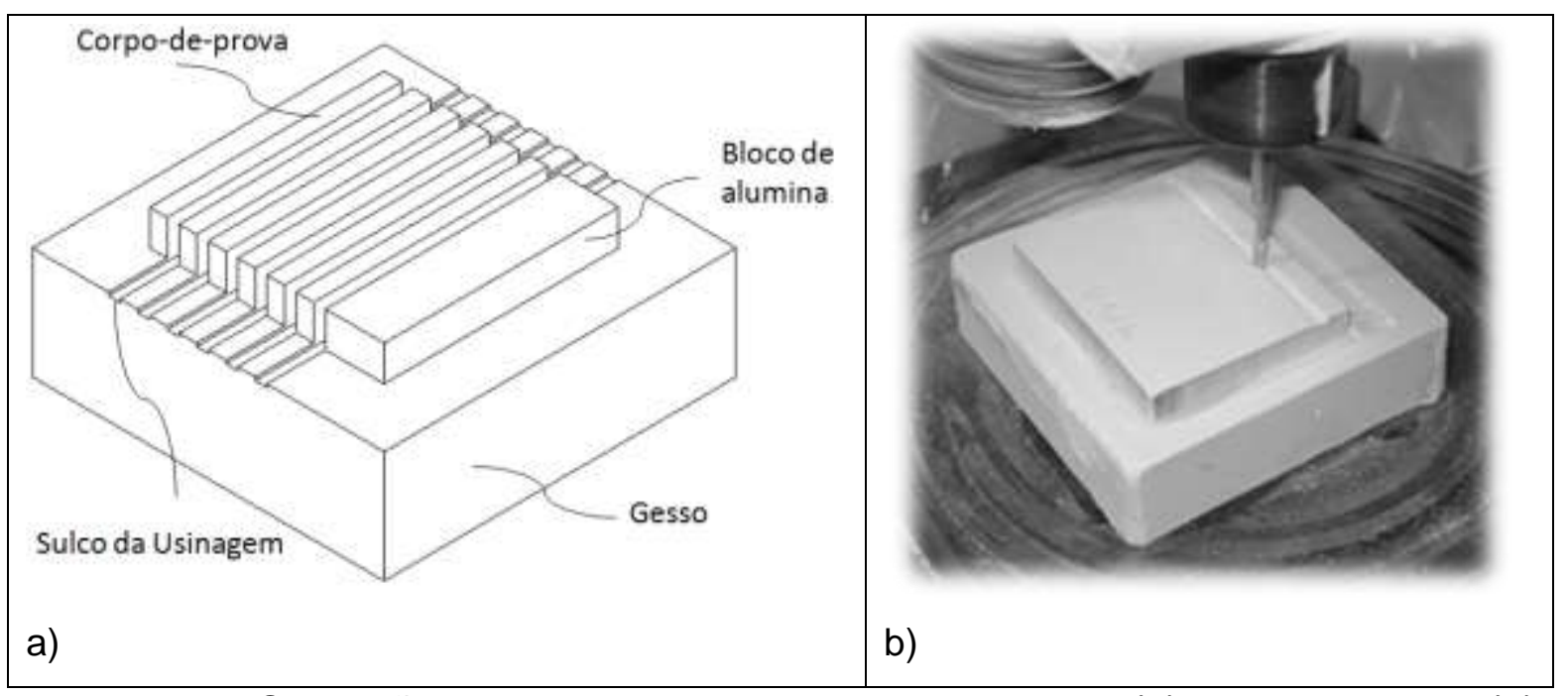

Figura 3.5 - Operação do corte dos corpos de prova, sendo (a) planejamento e (b) execução.

\subsubsection{Análise das peças}

As barras de perfil retangular usinadas em verde, sob as diferentes condições de corte, com ferramentas de materiais diferentes e ligantes diferentes, foram sinterizadas e submetidas ao ensaio de ruptura à flexão e tiveram as suas superfícies usinadas analisadas pela medida da rugosidade.

O processo de sinterização dos corpos-de-prova foi feito em um forno elétrico do tipo câmara, da marca Lindberg Blue ${ }^{\circledR}$, com uma rampa de aquecimento, patamar e rampa de resfriamento, com duração total de 900 minutos, e temperatura máxima de $1600^{\circ} \mathrm{C}$ com um patamar de 120 minutos de duração. O tempo e a temperatura descritos foram os necessários para alcançar as características de sinterização requeridas para o material da peça, como o aumento do tamanho de grão necessário e alcançar a melhor resistência mecânica, Figura 3.6. 


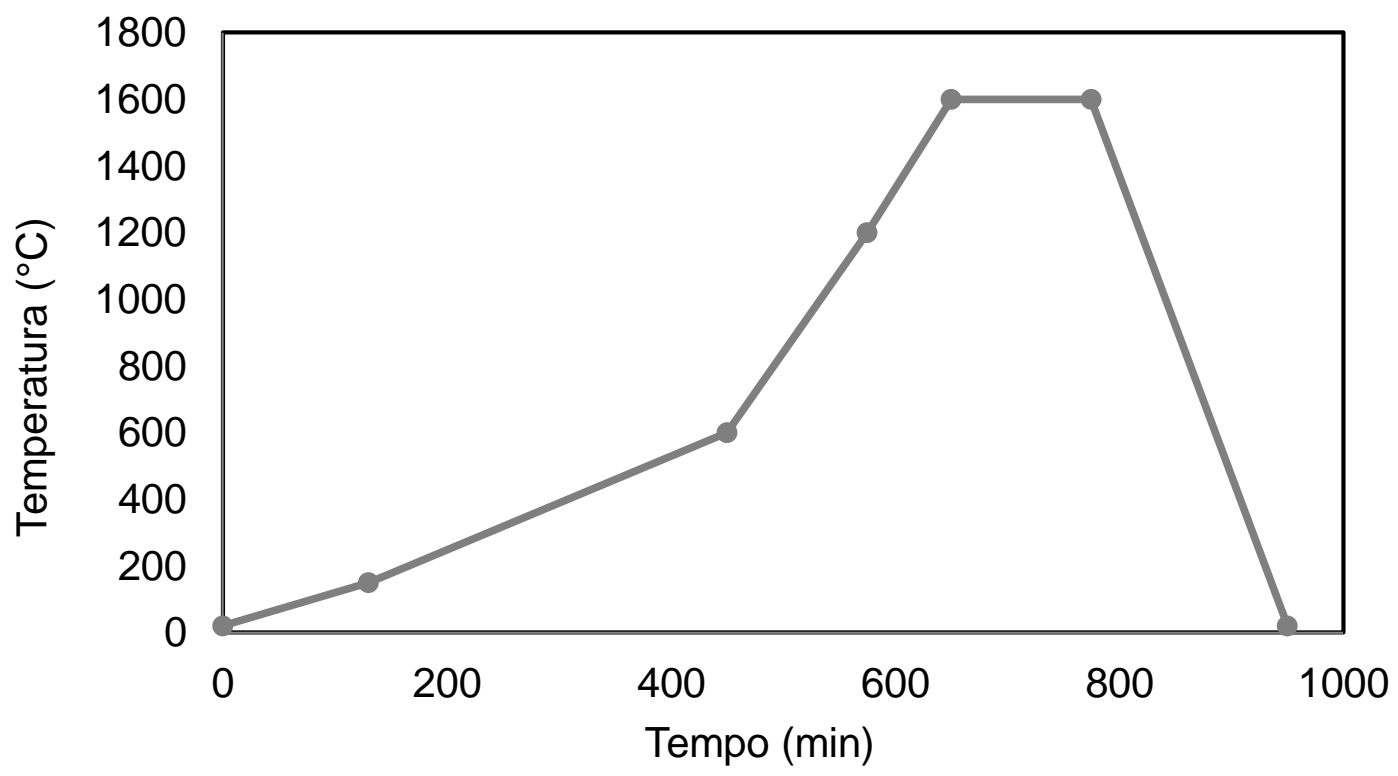

Figura 3.6 - Rampa de aquecimento e temperatura do processo de sinterização.

\subsubsection{Resistência mecânica}

Os corpos-de-prova foram analisados quanto a resistência à ruptura por flexão a quatro pontos, segundo norma ASTM C1161-02c, sendo suas dimensões aproximadas após a sinterização, de $33 \times 4,7 \times 3,4 \quad \mathrm{~mm}$ (comprimento/largura/espessura).

Foi utilizada a Máquina Universal de Ensaios da $\mathrm{EMIC}^{\circledR}$ com velocidade do travessão em $0,5 \mathrm{~mm} / \mathrm{min}$ com célula de carga de $2 \mathrm{kN}$. Foi aplicado span (distância entre os apoios) de $20 \mathrm{~mm}$ apoiado pelas faces usinadas, uma vez que as maiores tensões ocorrem nestas superfícies e a introdução de defeitos se manifesta nas propriedades mecânicas.

\subsubsection{Rugosidade}

A rugosidade dos corpos-de-prova foi medida em um rugosímetro perfilometro Form Talysurf Series 1120 da marca Taylor Robson ${ }^{\circledR}$. Foi utilizado o filtro ISO-2CR, Cutoff (LC) de 0,25 mm e comprimento de amostragem de 1,5 $\mathrm{mm}$ para a medição da rugosidade média aritmética $(\mathrm{Ra})$. 


\subsubsection{Estratégia de usinagem em verde na fabricação de um cilindro}

Para a fabricação de um corpo-de-prova em formato de cilindro a partir de um tarugo de perfil redondo conformado bruto, é relacionado a forma do objeto ao tipo de processo que pode ser aplicado a ele segundo a Tabela 3.1. Neste caso, se tem o torneamento cilíndrico externo e a retificação cilíndrica externa como opções. A escolha pelo torneamento ou a retificação, fica em relação ao tipo de acabamento superficial obtido por cada processo. A retificação pode proporcionar menor rugosidade superficial comparado com o torneamento.

Para o efeito do estudo, este corpo-de-prova, também, necessitará do melhor acabamento possível alcançado pela usinagem, neste caso, foi decidido pela retificação, que poder ser por comando manual ou CNC, como é demonstrado na Tabela 3.2. A peça também tem a necessidade de precisão dimensional, que é melhor obtida por máquinas de controle CNC (Tabela 3.2), uma vez que não haverá a intervenção do homem nos posicionamentos da ferramenta na execução da usinagem.

A retificadora cilíndrica externa, mesmo sendo CNC, apresenta uma construção simples com apenas 2 graus de liberdade para a sua movimentação. A forma do corpo-de-prova, também sendo simples, deverá utilizar o rebolo como ferramenta de corte (Tabela 3.3), uma vez que discos são melhores aplicados a peças free-form. A escolha pelo material do rebolo ficará em função de seu custo, uma vez que a cerâmica em seu estado verde apresenta baixa resistência mecânica, e poderiam ser utilizadas ferramentas de diamante, CBN ou de alumina eletrofundida (Tabela 3.3). Com o conhecimento de que diamante e CBN possuem custo elevado, a fabricação de rebolos com esses materiais ficaria dispendiosa, que, além disso, possui uma construção diferenciada, utilizando um corpo metálico e ligante metálico para a fixação dos abrasivos. A alumina eletrofundida, por sua vez, apresenta baixo custo e a construção do rebolo é simplificada, utilizando ligantes, também, de baixo custo, sendo por principio a preferência desse rebolo para a usinagem em verde nesse estudo.

A escolha do melhor ligante a ser utilizado no pó cerâmico (Tabela 3.4) fica determinado pelo estudo feito neste experimento. Os cilindros obtidos foram sinterizados e submetidos ao ensaio de ruptura à flexão e tiveram as suas 
superfícies usinadas analisadas pela medida da rugosidade, os resultados indicam o melhor tipo de ligante a ser utilizado na estratégia de usinagem em verde.

Com a escolha destas variáveis é possível obter a matriz de decisão para estratégia de usinagem em verde parcial para a produção de corpos-de-prova de formato de cilíndrico (Figura 3.7). Sua resolução é finalizada no tópico resultados e discussão, a qual receberá as informações da análise dos tipos de ligantes. 


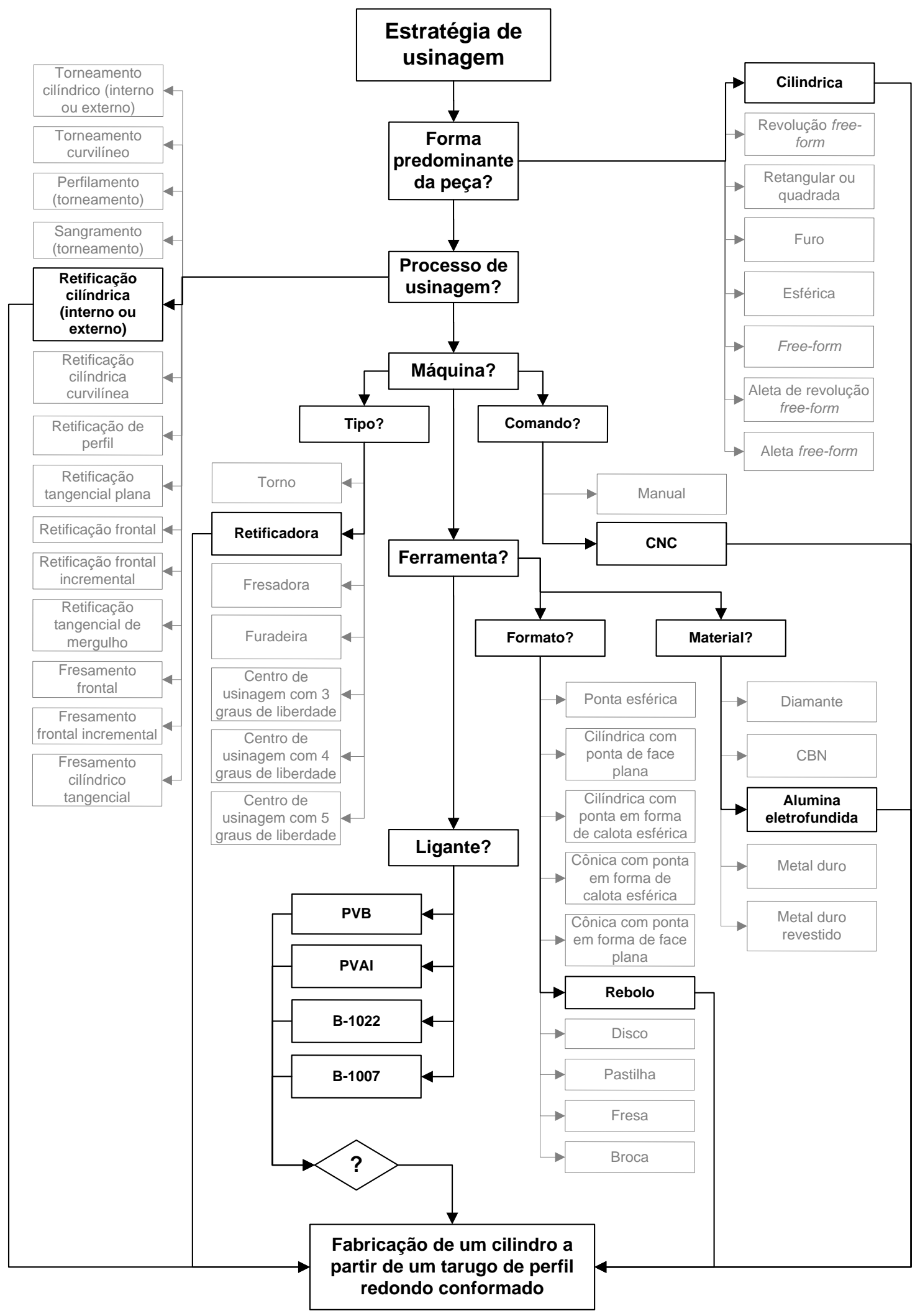

Figura 3.7 - Matriz de decisão para estratégia de usinagem em verde parcial na fabricação de um cilíndrico a partir de um tarugo de perfil redondo conformado. 


\subsubsection{Preparação dos corpos de prova}

Para a obtenção dos corpos-de-prova em formato de cilindros com dimensões de $45 \times 7 \mathrm{~mm}$ (comprimento/diâmetro), que foram usinados em verde utilizando a matriz de decisão para estratégia de usinagem em verde, foram utilizados blanks no formato de tarugos de perfil redondo bruto com dimensões aproximadas de 55x10 mm (comprimento/diâmetro), prensados isostaticamente à $100 \mathrm{MPa}$ e $200 \mathrm{MPa}$. Os corpos foram tratados termicamente à $100^{\circ} \mathrm{C}$ por 12 horas, para homogeneizar e aliviar as tensões provenientes da prensagem. Sendo aderidos, com o auxilio de um adesivo térmico, na superfície de uma base metálica por uma de suas superfícies planas, para posterior usinagem.

\subsubsection{Matéria prima e manufatura}

Como matéria prima, mais uma vez, foi empregada a Alumina Calcinada A1000-SG, (Almatis, Inc.) com diâmetro médio equivalente de partícula de 0,4 $\mu \mathrm{m}$, área superficial de $7,7 \mathrm{~mm}^{2} / \mathrm{g}$, $\rho_{\text {real }}: 3,99 \mathrm{~g} / \mathrm{cm}^{3}$. Como ligante foi utilizado o PVAl (2 \% em peso) juntamente com o poliacrilato de amônia (dispersal 130) (1 \% em peso) em meio aquoso à 68 vol\%, o PVB (2 \% em peso) em meio alcoólico (álcool Isopropílico) a 68 vol\%, o ligante acrílico DURAMAX ${ }^{\mathrm{TM}}$ B-1022 (2 \% em peso) juntamente com o DURAMAX ${ }^{\mathrm{TM}} \mathrm{D}-3005$ (1\% em peso) em meio aquoso à 68 vol\% e o ligante acrílico DURAMAX ${ }^{\mathrm{TM}}$ B-1007 (2 \% em peso) juntamente com o DURAMAX ${ }^{\mathrm{TM}}$ D-3005 (1 \% em peso) em meio aquoso à 68 vol\% os quais foram misturados em moagem de bolas por 12 horas e, posteriormente, secos e granulados manualmente.

As formulações foram denominadas de acordo com a Tabela 3.7, e com cada formulação foram obtidos 20 tarugos brutos prensados isostaticamente, dos quais 10 foram prensados a $100 \mathrm{MPa}$ e outros 10 prensados a $200 \mathrm{MPa}$. Dos 10 tarugos brutos prensados a $100 \mathrm{MPa}, 5$ foram submetidos ao ensaio de flexão em verde e os 5 restantes foram usinados em verde e então sinterizados para análise da resistência a flexão e rugosidade. $\mathrm{E}$ dos 10 tarugos brutos prensados a $200 \mathrm{MPa}, 5$ foram submetidos ao ensaio de flexão em verde e os 5 restantes foram usinados em verde e então sinterizados para análise da resistência a flexão e rugosidade. 
Tabela 3.7 - Denominação das formulações.

\begin{tabular}{|c|c|c|c|}
\hline Material & Ligante & Defloculante & Meio liquido \\
\hline A & PVAL & Poliacrilato de Amônio & Água destilada \\
\hline B & PVB & PVB & Álcool Isopropílico \\
\hline C & B-1022 & D-3005 & Água destilada \\
\hline B & B-1007 & D-3005 & Água destilada \\
\hline
\end{tabular}

\subsubsection{Planejamento e ensaios de usinagem}

Os experimentos de usinagem seguiram o planejamento apresentado na Tabela 3.8, sendo que os parâmetros de usinagem foram dados experimentais de Margarido (2012), os quais foram responsáveis pelo melhor valor de resistência mecânica a flexão na usinagem em verde de alumina spray-dried com $1 \% \mathrm{em}$ peso de PVAI. Foi empregada uma retificadora CNC de 2 graus de liberdade, como 0 especificado na matriz de decisão, equipada com um spindle dicing (D05716/3) de mancal aerostático da marca LoadPoint Bearing Ltda., rotacionando a $11.400 \mathrm{rpm}$, utilizando como ferramenta de corte um rebolo de alumina eletrofundida de \#80 mesh com ligante vitrificado (38A80 IVH) da marca Norton Saint-Gobain Ltda., de

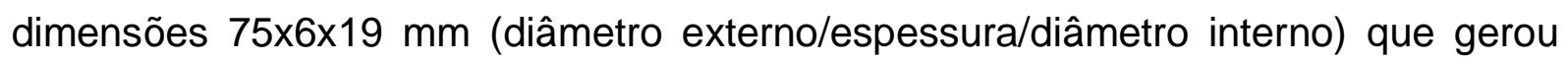
velocidade de corte $\left(v_{c}\right)$ de $45 \mathrm{~m} / \mathrm{s}$.

Tabela 3.8 - Planejamento experimental.

\begin{tabular}{|c|c|c|c|c|c|c|}
\hline 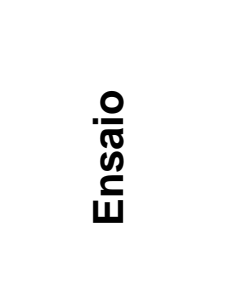 & 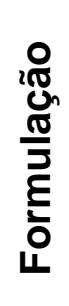 & 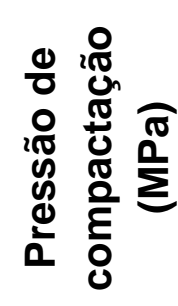 & 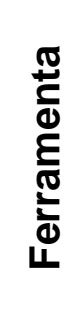 & 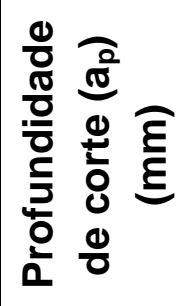 & 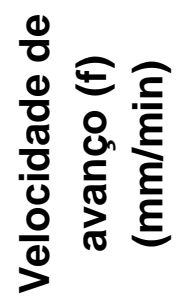 & 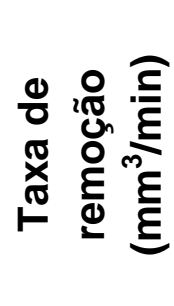 \\
\hline AA1-1-400 & \multirow{2}{*}{ A } & 100 & \multirow{8}{*}{ 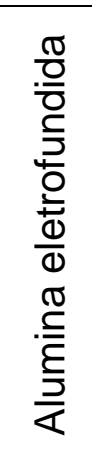 } & \multirow{8}{*}{1} & \multirow{8}{*}{400} & \multirow{8}{*}{10.000} \\
\hline AA2-1-400 & & 200 & & & & \\
\hline BA1-1-400 & \multirow{2}{*}{ B } & 100 & & & & \\
\hline BA2-1-400 & & 200 & & & & \\
\hline CA1-1-400 & \multirow{2}{*}{ C } & 100 & & & & \\
\hline CA2-1-400 & & 200 & & & & \\
\hline DA1-1-400 & \multirow{2}{*}{ D } & 100 & & & & \\
\hline DA2-1-400 & & 200 & & & & \\
\hline
\end{tabular}


Para medir o torque de usinagem foi utilizado um sensor de torque (MKDC-5) de capacidade máxima de 5,0 N.m da MK Controle e Instrumentos Ltda, que foi acoplado entre o corpo-de-prova e um servo-motor (WEG SWA56-2,5-20) com servo-conversor (WEG SCA050004) da WEG Ltda. Os dados enviados pelo torquimetro foram coletados por um módulo de aquisição (USB 6009 - 14 BITS de resolução) da National Instruments Ltda. O servo-motor e o sensor de torque foram controlados pelo software Labview pela interface National Instruments. O intuito do servo-motor e de rotacionar o corpo-de-prova para que o material seja removido pelo rebolo formando a superfície circular. A rotação do servo-motor foi fixada a 600 rpm e, quando acionado, foi programado para ganhar rotação gradativamente, para não ter o problema de quebrar a peça.

A montagem da bancada de ensaio é mostrada na Figura 3.8, onde se pode observar a retificadora à direita e o painel elétrico junto com o computador à esquerda. Na Figura 3.9 (a) é observado o desenho do planejamento da usinagem e na Figura 3.9 (b) a execução da usinagem para a obtenção das peças.

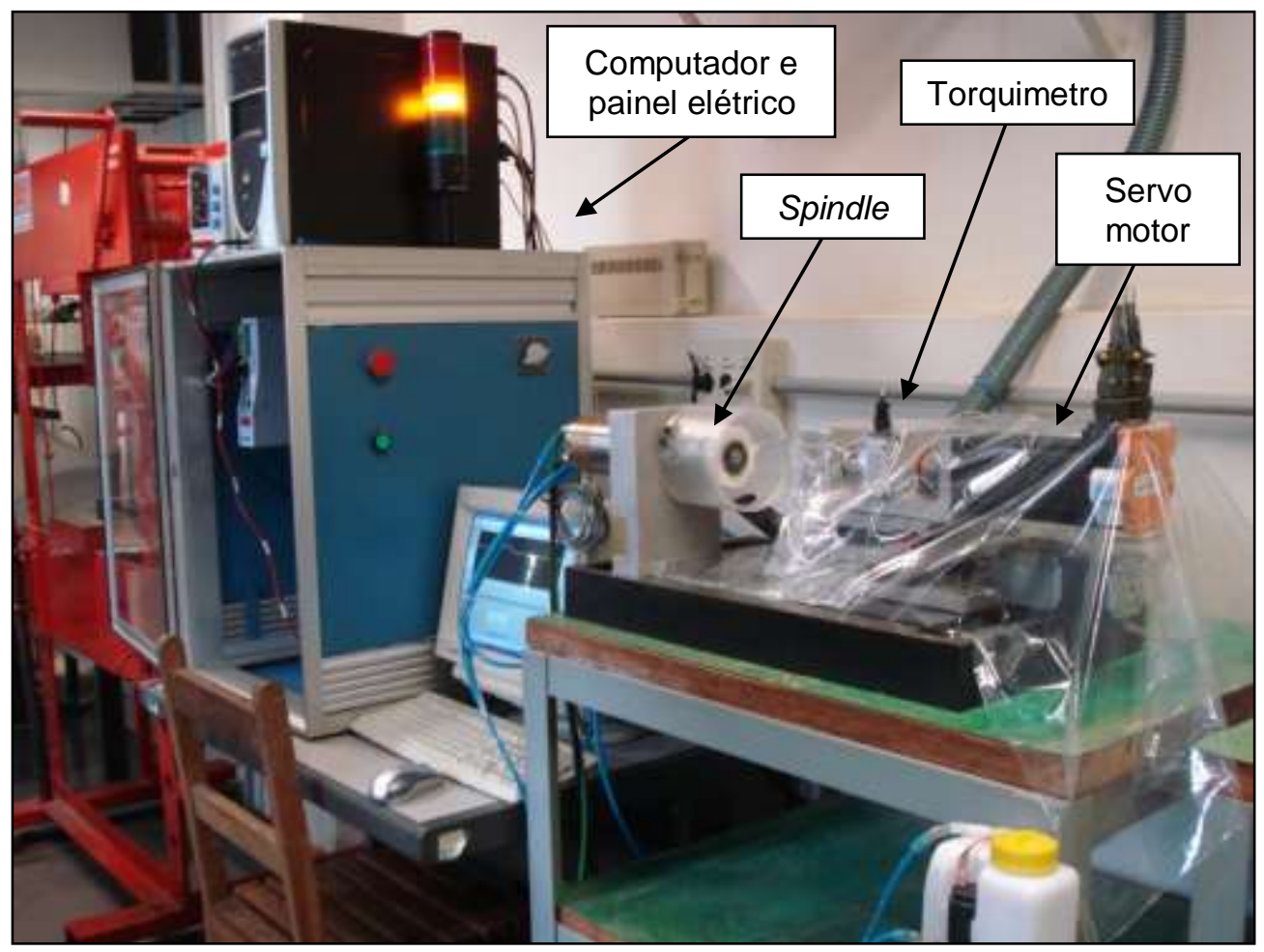

Figura 3.8 - Banco de ensaio para usinagem de tarugos de perfil redondo. 


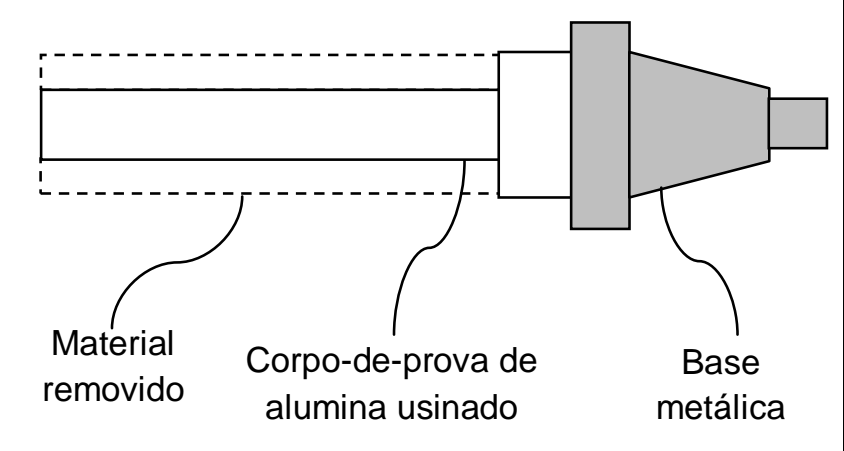

(a)

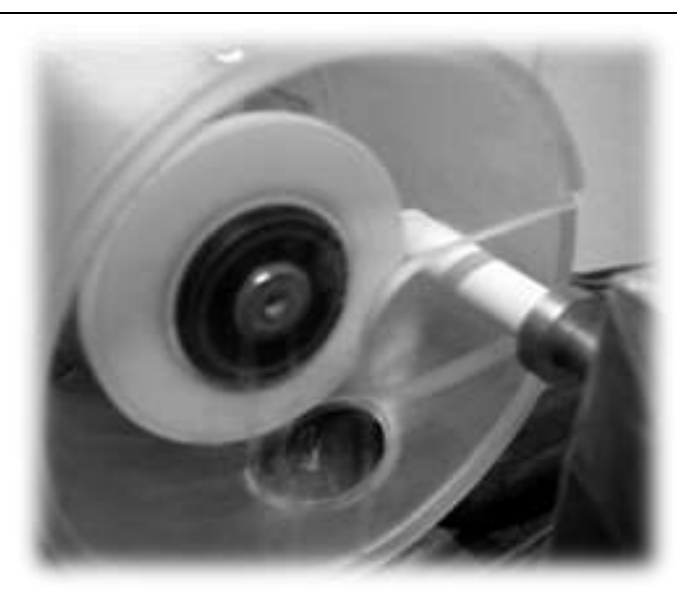

(b)

Figura 3.9 - Operação do corte dos corpos de prova, sendo (a) planejamento e (b) execução.

Para o pleno funcionamento da retificadora CNC foi necessário a construção de um painel elétrico, o qual acondiciona os módulos de controle do spindle dicing, servo motor e Labview. Para o desenvolvimento do painel foi realizado o estudo da disposição dos módulos juntamente com a elaboração e montagem do esquema elétrico para o funcionamento dos mesmos.

\subsubsection{Análise das peças}

Tarugos brutos prensados a $100 \mathrm{MPa}$ e $200 \mathrm{MPa}$ no estado verde foram submetidos ao ensaio de ruptura a flexão para análise da resistência mecânica em verde.

Em seguida, cilindros usinados em verde, prensados a $100 \mathrm{MPa}$ e $200 \mathrm{MPa}$, sob parâmetros fixos de usinagem, com a mesma ferramenta e ligantes diferentes, foram sinterizadas (conforme o gráfico da Figura 3.7) e submetidas ao ensaio de ruptura à flexão para análise da resistência mecânica e tiveram as suas superfícies usinadas analisadas pela medida da rugosidade.

Após estas análises, foi realizado um novo ensaio, o qual é discutido no tópico resultados e discussão, com o ligante que obtive o melhor resultado em termos de resistência mecânica e rugosidade, para analisar seu desempenho, quando for modificada sua concentração para 1, 1,5 e 2,5\% em peso. Tarugos brutos obtidos com tais formulações foram usinados em verde (sob parâmetros fixos de usinagem) e sinterizados (conforme o gráfico da Figura 3.7) e submetidos ao 
ensaio de ruptura à flexão, para análise da resistência mecânica, e tiveram as suas superfícies usinadas analisadas pela medida da rugosidade.

\subsubsection{Resistência mecânica}

Os corpos-de-prova foram analisados quanto à resistência a ruptura por flexão a quatro pontos, segundo norma ASTM C1684-08, sendo suas dimensões aproximadas após a sinterização de 40x6 mm (comprimento/diâmetro).

Foi utilizada uma máquina Bionix® Servohydraulic Test Systems (370.02) de ensaio a flexão e torção da MTS Ltda., com velocidade do travessão de 0,2 $\mathrm{mm} / \mathrm{min}$, célula de carga de 150 kN e aplicado span de $20 \mathrm{~mm}$.

\subsubsection{Rugosidade}

A rugosidade dos corpos-de-prova foi medida em um rugosímetro portátil (Surtronic 3+) da Taylor Robson Ltda. Foi utilizado o filtro gausseano, Cutoff (Lc) de 0,8 $\mathrm{mm}$ e comprimento de dados de $4 \mathrm{~mm}$ para a medição do $\mathrm{Ra}$.

\subsubsection{Estratégia de usinagem em verde na fabricação de uma barra de perfil retangular com uma superfície funcional plana}

Para a obtenção de um corpo-de-prova em formato de barra com perfil retangular com uma superfície funcional plana (superfície utilizada para deslizamento, por exemplo), deve-se relacionar a forma do objeto em relação ao tipo de processo que pode ser aplicado a ele (Tabela 3.1) e, neste caso, se têm a retificação tangencial plana, a retificação frontal, o fresamento cilíndrico tangencial e o fresamento frontal como opções. Neste ponto, a escolha pelo fresamento ou a retificação se dá em relação ao tipo de acabamento obtido por cada processo.

Como a retificação pode proporcionar melhor acabamento superficial comparado com o fresamento, neste caso, fica a escolha pela retificação, que poderá ser realizada por uma retificadora (comando CNC ou manual) ou um centro de usinagem, como é demonstrado na Tabela 3.2.

O corpo-de-prova deverá ser fabricado a partir de um bloco conformado em verde, o qual terá sua lateral usinada e que permite a obtenção de vários corpos-deprova por meio de seu seccionamento. Como apenas uma de suas faces é uma face 
funcional, o formato final do corpo-de-prova é obtido pelo corte por meio de um serra manual. Nesse caso, a utilização de uma retificadora convencional permitiria a obtenção da face funcional da peça. Porém, um centro de usinagem de 3 graus de liberdade é utilizado como uma retificadora, devido a sua disponibilidade no laboratório, na usinagem do corpo-de-prova.

O processo de usinagem chamado de retificação tangencial plana (Tabela 3.1) é o necessário para a obtenção da superfície funcional, e permitirá o uso da ferramenta ponta montada. A forma da ferramenta, por sua vez, não necessita ser complexa, cabendo uma de formato cilíndrico com ponta de face plana (Tabela 3.3) ser a requerida para a usinagem.

A escolha do material da ferramenta (Tabela 3.3) e do tipo de ligante (Tabela 3.4) fica sujeito a análise dos corpos-de-prova que foram usinados sob diferentes parâmetros de corte, utilizando diferentes ligantes na composição do pó e diferentes materiais da ferramenta.

As barras, com as superfícies funcionais obtidas pela usinagem em verde, foram sinterizadas e tiveram as suas superfícies analisadas pela medida da rugosidade. As diferentes ferramentas foram analisadas pelo empastamento causado pelo tipo de ligante e pela força de corte. O que diz qual o melhor tipo de ligante, material da ferramenta e parâmetros de corte a ser utilizado na estratégia de usinagem em verde.

Com a escolha destas variáveis é possível obter a matriz de decisão para estratégia de usinagem em verde parcial para a produção de corpos-de-prova com uma superfície funcional (Figura 3.10). Sua resolução é finalizada no tópico resultados e discussão, a qual recebe as informações da análise do material da ferramenta, do tipo de ligante, empastamento da ferramenta e dos parâmetros de corte que foram necessárias para a obtenção final da peça. 


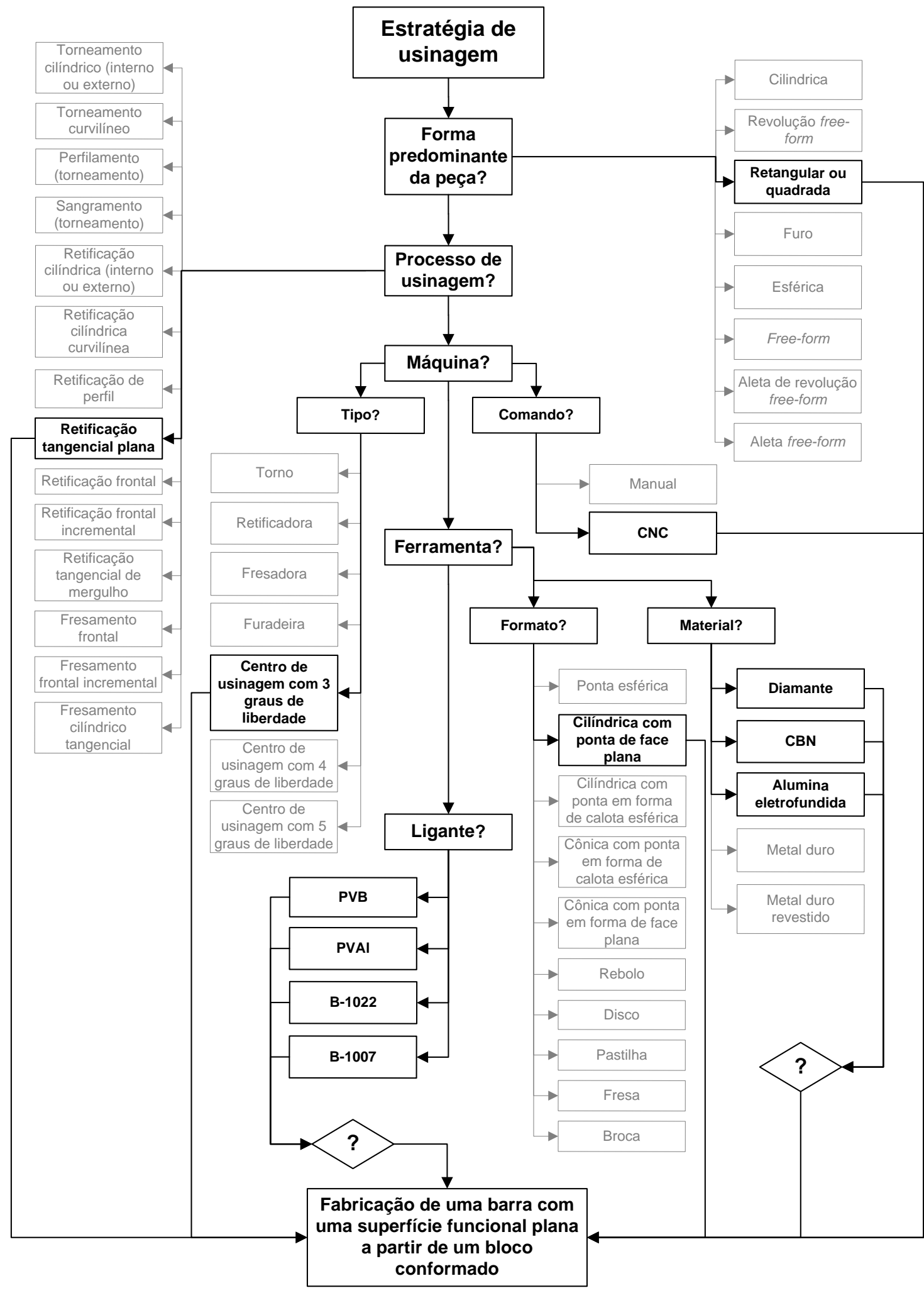

Figura 3.10 - Matriz de decisão para estratégia de usinagem em verde parcial na fabricação de uma barra de perfil retangular com uma superfície funcional a partir de um bloco conformado. 


\subsubsection{Preparação dos corpos de prova}

Para obter os corpos-de-prova de uma superfície funcional em formato de barras de perfil retangular foram utilizados blanks no formato de blocos com

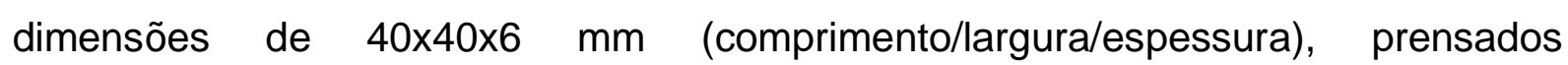
uniaxialmente à $80 \mathrm{MPa}$ seguido de prensagem isostática a $200 \mathrm{MPa}$ (dado retirado dos resultados das matrizes de decisões já estudadas), que foram usinados em verde utilizando a matriz de decisão para estratégia de usinagem em verde. Os corpos foram tratados termicamente à $100^{\circ} \mathrm{C}$ por 12 horas, para homogeneizar e aliviar, as tensões provenientes da prensagem. Para permitir a usinagem, os blocos foram aderidos, com cianoacrilato, na superfície de uma base de gesso pelo centro de uma de suas faces planas $(40 \times 40 \mathrm{~mm})$, o qual foi descartado após a remoção dos corpos-de-prova.

\subsubsection{Matéria prima e manufatura}

Como matéria prima, mais uma vez, foi empregada a Alumina Calcinada A1000-SG, (Almatis, Inc.) com diâmetro médio equivalente de partícula de 0,4 $\mu \mathrm{m}$, área superficial de $7,7 \mathrm{~mm}^{2} / \mathrm{g}$, $\rho_{\text {real }}: 3,99 \mathrm{~g} / \mathrm{cm}^{3}$. Como ligante foi utilizado o PVAl (2 \% em peso) juntamente com o poliacrilato de amônia (dispersal 130) (1 \% em peso) em meio aquoso à 68 vol\%, o PVB (2\% em peso) em meio alcoólico (álcool Isopropílico) a 68 vol\%, o ligante acrílico DURAMAX ${ }^{\mathrm{TM}}$ B-1022 (2 \% em peso) juntamente com o DURAMAX ${ }^{\mathrm{TM}} \mathrm{D}-3005$ ( $1 \%$ em peso) em meio aquoso à $68 \mathrm{vol} \% \mathrm{e}$ o ligante acrílico DURAMAX ${ }^{\mathrm{TM}}$ B-1007 (2 \% em peso) juntamente com o DURAMAX ${ }^{\mathrm{TM}}$ D-3005 ( $1 \%$ em peso) em meio aquoso à 68 vol\% os quais foram misturados em moagem de bolas por 12 horas e, posteriormente, secos e granulados manualmente.

As formulações foram denominadas de acordo com a Tabela 3.9, e com cada formulação foi obtido 1 bloco. A usinagem foi realizada nas faces laterais do bloco, neste caso, cada bloco permitiu a obtenção de 4 corpos-de-prova. Sendo que cada corpo-de-prova foi submetido a uma condição de usinagem diferente para posterior análise. 
Tabela 3.9 - Denominação das formulações.

\begin{tabular}{|c|c|c|c|}
\hline Material & Ligante & Defloculante & Meio liquido \\
\hline A & PVAL & Poliacrilato de Amônio & Água destilada \\
\hline B & PVB & PVB & Álcool Isopropílico \\
\hline C & B-1022 & D-3005 & Água destilada \\
\hline D & B-1007 & D-3005 & Água destilada \\
\hline
\end{tabular}

\subsubsection{Seleção da ferramenta}

Ferramentas do formato descrito na matriz de decisão (pontas montada de formato cilíndrico com ponta de face plana) foram aplicadas utilizando abrasivos de diamante, CBN e alumina eletrofundida.

Para as ferramentas de diamante e CBN foram utilizados como ligantes, para a fixação dos grãos abrasivos, a eletrodeposição metálica de níquel (ligante metálico) e resina para fixação dos grãos abrasivos (ligante resinoide). Já para a ferramenta de alumina-eletro fundida foi utilizado ligante vitrificado.

A opção pelo diamante e o CBN se deve a característica de alta dureza apresentada por estes abrasivos, o que reflete na vida da ferramenta. O diamante, material mais duro encontrado na natureza, e o CBN, material artificial com sua dureza logo abaixo do diamante. Arestas "afiadas" são indispensáveis na usinagem e isto se deve a natureza do grão abrasivo, ou seja, se o grão é natural, artificial ou se foi fundido e fraturado como o caso da alumina eletrofundida utilizada com terceira opção para o ensaio.

A seleção da ferramenta de usinagem foi baseada na força de corte e no empastamento da ferramenta causado pelo ligante cerâmico utilizado.

\subsubsection{Planejamento e ensaios de usinagem}

Foi empregado um centro de usinagem de 3 graus de liberdade, como 0 especificado na matriz de decisão, equipado com um spindle (Precise) da Chapman Laboratory Ltda., de rolamentos esféricos de precisão com rotação de 36.500 rpm e $500 \mathrm{~W}$ de potência. 
Como foi realizada uma análise das ferramentas e parâmetros de usinagem, a princípio, foi empregado ferramentas de diâmetros iguais, porém com abrasivo de diamante e CBN e ligante metálico e resinoide, na usinagem do bloco de alumina com ligante acrílico B-1007, o qual seguiu o planejamento de usinagem apresentado na Tabela 3.10. Posteriormente, no tópico resultados e discussão, outros planejamentos foram realizados até a definição da ferramenta e seus respectivos parâmetros de usinagem.

Tabela 3.10 - Planejamento experimental.

\begin{tabular}{|c|c|c|c|c|c|c|}
\hline 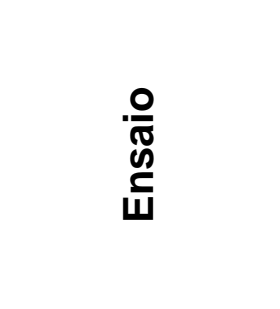 & 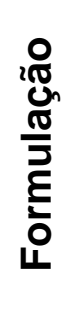 & 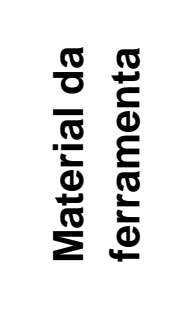 & 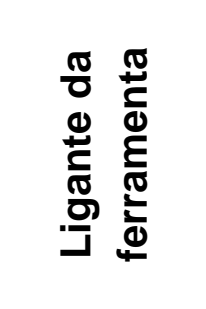 & 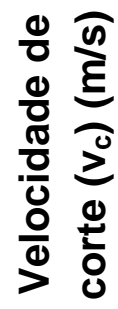 & 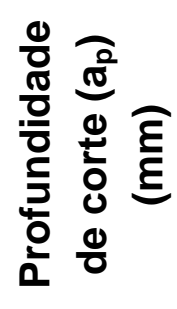 & 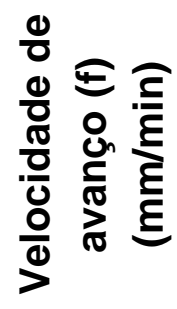 \\
\hline DDM-4-1-100 & \multirow{4}{*}{ D } & \multirow{2}{*}{ Diamante } & Metálico & \multirow{4}{*}{7,64} & \multirow{4}{*}{1} & \multirow{4}{*}{100} \\
\hline DDR-4-1-100 & & & Resinoide & & & \\
\hline DCM-4-1-100 & & \multirow{2}{*}{ CBN } & Metálico & & & \\
\hline DCR-4-1-100 & & & Resinoide & & & \\
\hline
\end{tabular}

As dimensões das ferramentas escolhidas para este primeiro ensaio foram de 4x6 mm (diâmetro/comprimento) com abrasivo de diamante e de CBN de granulometria \#80 mesh, as quais geraram velocidade de corte $\left(v_{c}\right)$ de 7,64 m/s. A descrição das ferramentas de diamante gerada pelo fabricante foi D PMD 040 D 181 (ligante metálico) e D PMR 040 D 181 (ligante resinoide). Já a descrição das ferramentas de diamante gerada pelo fabricante foi B PMD 040 B 181 (ligante metálico) e B PMR 040 B 181 (ligante resinoide). Todas as ferramentas foram fabricadas pela empresa Master Diamond Ferramentas Ltda.

O material e ligante da ferramenta que obtiveram o melhor resultado de força de corte e empastamento, assim como o ligante cerâmico que obteve, também o melhor resultado, foram aplicados como dado de entrada para os ensaios posteriores. 
Para a medição da força de usinagem foi feito o projeto e a construção de uma mesa com mancais aerostáticos (mancal lubrificado a ar pressurizado para mínimo atrito no deslizamento), a qual permitiu a medição dos esforços nas coordenadas x e y, no plano horizontal, por meio de duas células de carga, cada uma fixada em um eixo coordenado. Essa mesa possui 6 mancais aerostáticos, em sua parte inferior, a qual foi colocada sobre um vidro plano que serviu de base para a formação do colchão de ar, responsável pelo seu funcionamento.

Em seguida, uma estrutura foi projeta e fixada à mesa da máquina para servir de suporte para a mesa aerostática. Esta estrutura foi divida em duas partes, uma inferior e outra superior. A parte inferior se constitui de uma base maior com dois braços (dispostos nos eixos x e y), onde a base maior é utilizada para fixar o vidro e os braços, fixados nas laterais da base inferior que são responsáveis pela fixação das células de carga (um dos lados de cada célula de carga). A parte superior, por sua vez, se constitui de uma base menor, também, com dois braços (dispostos nos eixos $\mathrm{x}$ e $\mathrm{y}$ ), onde a base menor é utilizada para fixar a mesa aerostática e os braços, fixados nas laterais da base superior são responsáveis pela fixação das células de carga (outro lado de cada célula de carga). A base menor é, também, utilizada para a fixação do corpo-de-prova. A Figura 3.11 demonstra a estrutura montada na máquina, juntamente com suas partes: mesa aerostática e células de carga.

As duas células de carga utilizadas foram fabricadas pela MK Controle e Instrumentos Ltda., designadas como modelo MKCSA-5, e possuem capacidade máxima de $50 \mathrm{~N}$. Os dados enviados pelas células de carga foram coletados por um módulo de aquisição (USB 6009 - 14 BITS de resolução) da National Instruments Ltda controlado pelo software Labview, pela interface National Instruments. $O$ software necessitou do desenvolvimento de uma programação para a leitura simultânea das duas células de carga, que recebeu os dados enviados em milivolts $(\mathrm{mV})$, e os converteu em uma leitura de força em Newtons $(\mathrm{N})$.

Para a avaliação do empastamento, as ferramentas utilizadas foram pesadas antes e após a usinagem em uma balança de precisão (AUW-D Series) da marca Shimadzu Ltda, sendo que uma ferramenta nova foi utilizada para cada medição. $O$ intuito foi observar o aumento da massa da ferramenta, após a usinagem, que representa a quanto de material ficou aderido a ela. Para garantir o maior 
empastamento possível 5 passes, removendo material do corpo-de-prova, foi realizado com cada ferramenta antes da medição das massas.

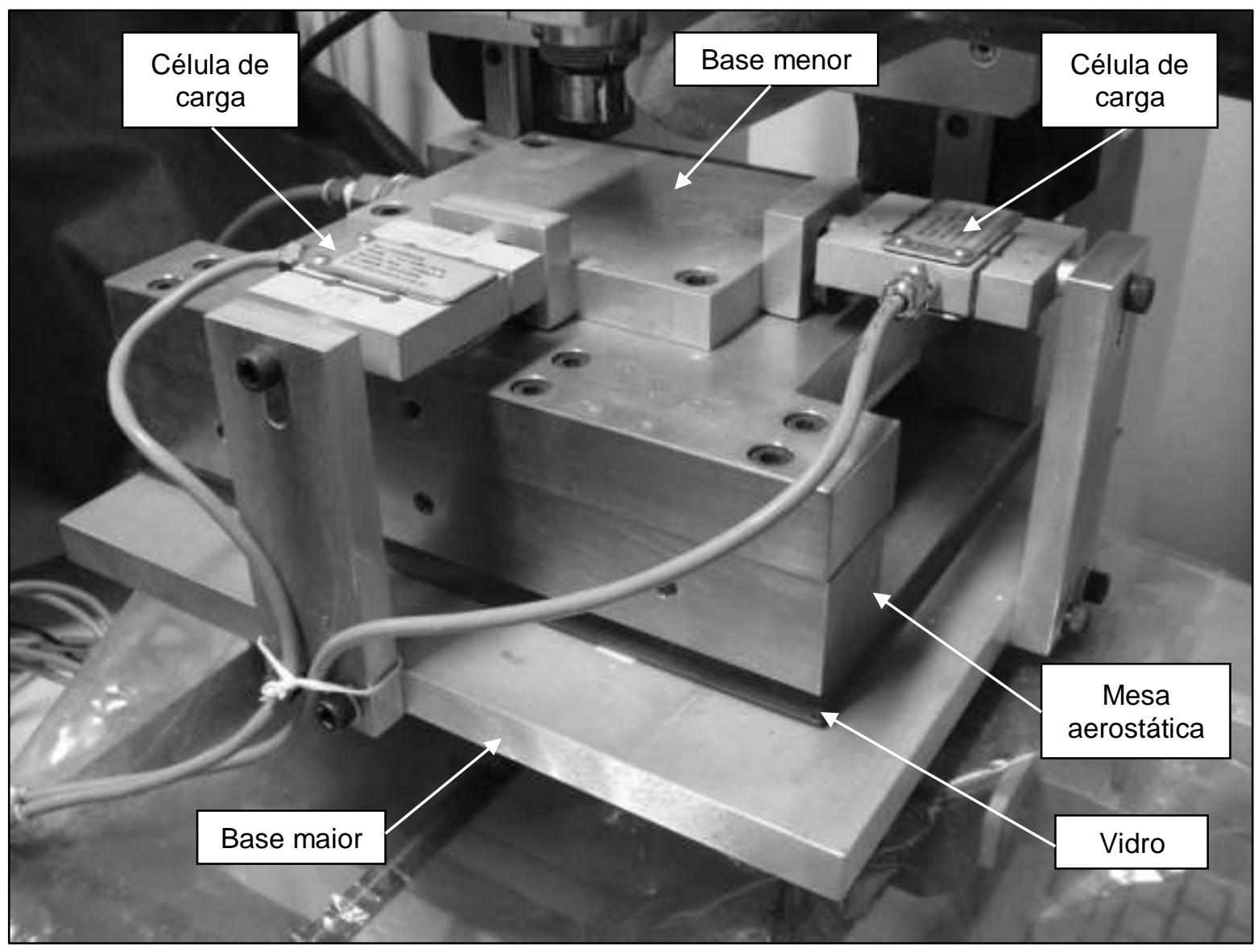

Figura 3.11 - Mesa aerostática para medição das forças de usinagem.

A montagem da bancada de ensaio é mostrada na Figura 3.12, onde se observa o centro de usinagem (acima) e o seu módulo de controle junto ao computador (abaixo). Na Figura 3.13 (a) é mostrado o desenho do planejamento da usinagem e na Figura 3.13 (b) a execução da usinagem para a obtenção das peças. 


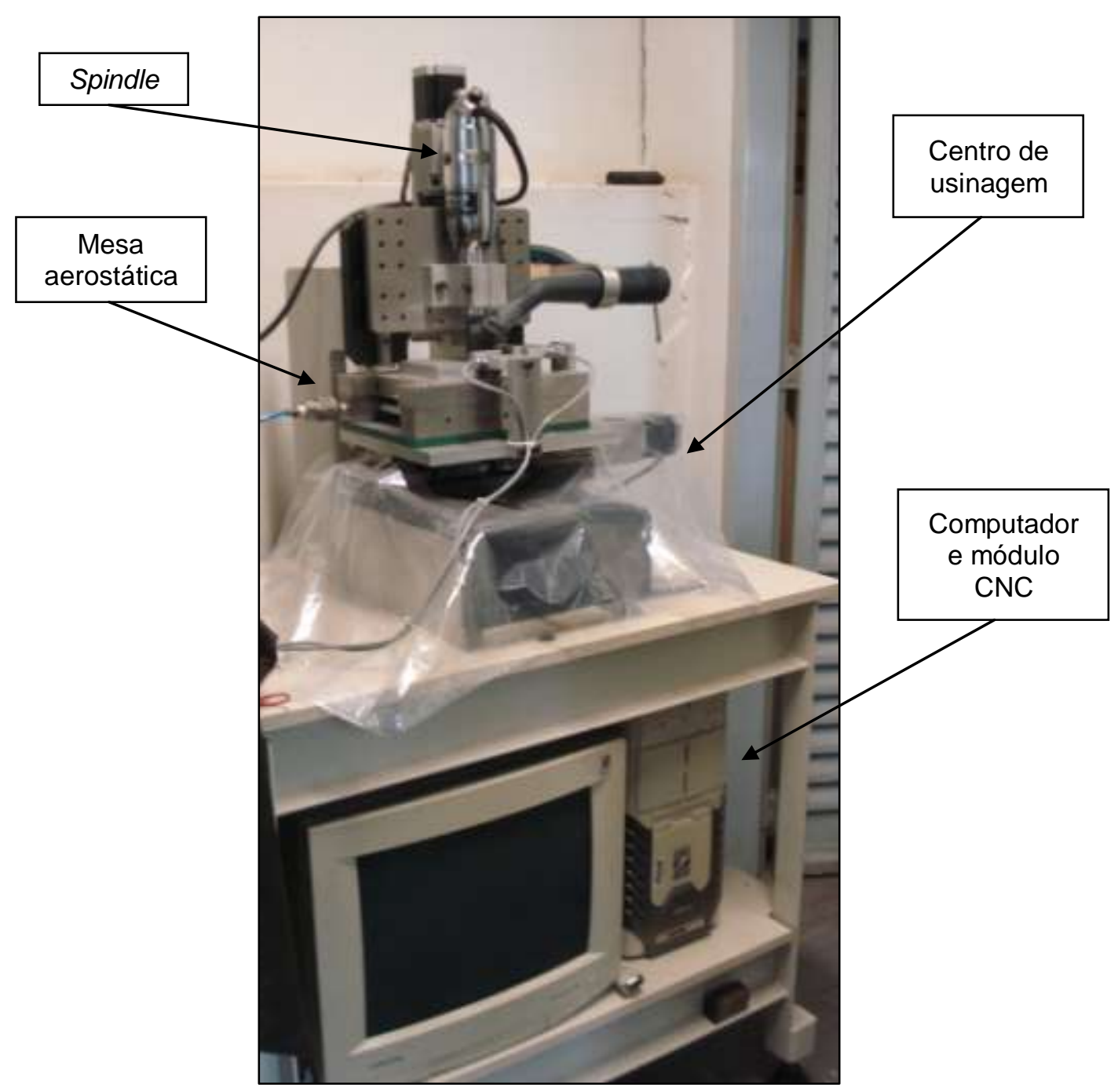

Figura 3.12 - Banco de ensaio para usinagem de uma barra de perfil retangular com uma superfície funcional.

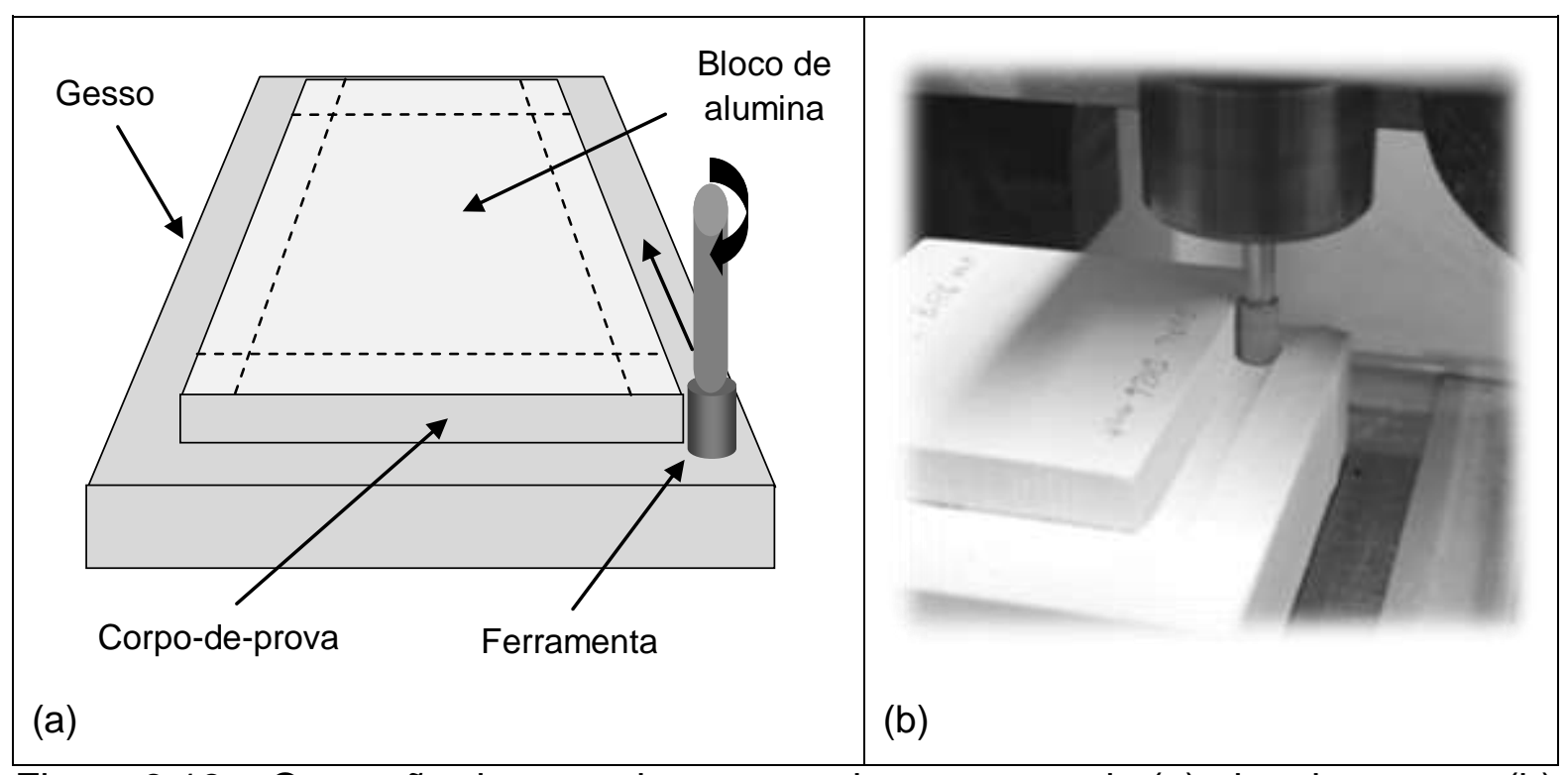

Figura 3.13 - Operação do corte dos corpos-de-prova, sendo (a) planejamento e (b) execução. 


\subsubsection{Análise das peças}

As barras de perfil retangular com uma superfície funcional usinadas em verde, sob as diferentes condições de corte, com ferramentas de materiais diferentes e ligantes diferentes, foram sinterizadas (conforme o gráfico da Figura 3.7) e tiveram as suas superfícies usinadas analisadas pela medida da rugosidade.

\subsubsection{Rugosidade}

A rugosidade dos corpos-de-prova foi medida em um rugosímetro óptico, sem contato, da marca Veeco®, modelo Wyko® NT 1100. O Ra foi calculado sem a utilização de filtro e com comprimento de dados de 0,461 mm.

\subsubsection{Estratégia de usinagem em verde para a obtenção de um furo}

Para a obtenção de furos em um bloco conformado deve-se relacionar a forma do objeto em relação ao tipo de processo que pode ser aplicado a ele (Tabela 3.1) e, neste caso, se têm a furação, a retificação frontal, a retificação frontal incremental, o fresamento frontal e o fresamento frontal incremental como opções. Neste ponto, a escolha pela furação, o fresamento ou a retificação, se dá em relação ao tipo de acabamento superficial obtido por cada processo. A retificação pode proporcionar menor rugosidade superficial comparado com o fresamento e a furação.

Para o efeito do estudo, o corpo-de-prova necessitará do melhor acabamento possível alcançado pela usinagem, neste caso, fica a escolha pela retificação, que poderá ser realizada por uma retificadora ou um centro de usinagem, como é demonstrado na Tabela 3.2. A peça também tem a necessidade de precisão dimensional, que é melhor obtida por máquinas de controle CNC (Tabela 3.2), uma vez que não haverá a intervenção do homem nos posicionamentos da ferramenta na execução da usinagem.

A escolha por uma retificadora CNC ou por um centro de usinagem depara em questões físicas de cada máquina. A furação deverá ser realizada em um bloco conformado em verde, que permite a obtenção de furos em sua superfície. Nesse caso, a utilização de uma retificadora CNC permite a obtenção do furo, porém, um 
centro de usinagem de 3 graus de liberdade é utilizado, devido a sua disponibilidade no laboratório, como uma retificadora na usinagem dos furos.

Devido o furo ser um formato simples, não exige um centro de usinagem com mais do que 3 graus de liberdade para a sua produção. $O$ processo de usinagem chamado de retificação frontal ou retificação frontal incremental (Tabela 3.1) pode ser escolhido para a fabricação, e permite o uso da ferramenta ponta montada. A forma da ferramenta, por sua vez, não necessitará ser complexa, cabendo uma de formato cilíndrico com ponta de face plana (Tabela 3.3) ser a requerida para a usinagem.

Neste estudo foi feito a aplicação dos dois tipos de processos de usinagem, a retificação frontal e retificação frontal incremental, na obtenção dos furos por usinagem em verde. Sendo aplicados os resultados de parâmetros de usinagem, ligante e material da ferramenta obtidos das matrizes de decisões já estudadas e que foram adequados a estes processos. A análise ficou baseada na introdução de lascamentos, causados na entrada e na saída da ferramenta na peça, após a usinagem realizada com cada processo.

Com a escolha destas variáveis é possível obter a matriz de decisão para estratégia de usinagem em verde parcial para a fabricação de furos em um bloco conformado (Figura 3.14). Sua resolução é finalizada no tópico resultados e discussão, a qual receberá a informação da análise dos processos de usinagem para a obtenção final da peça. 


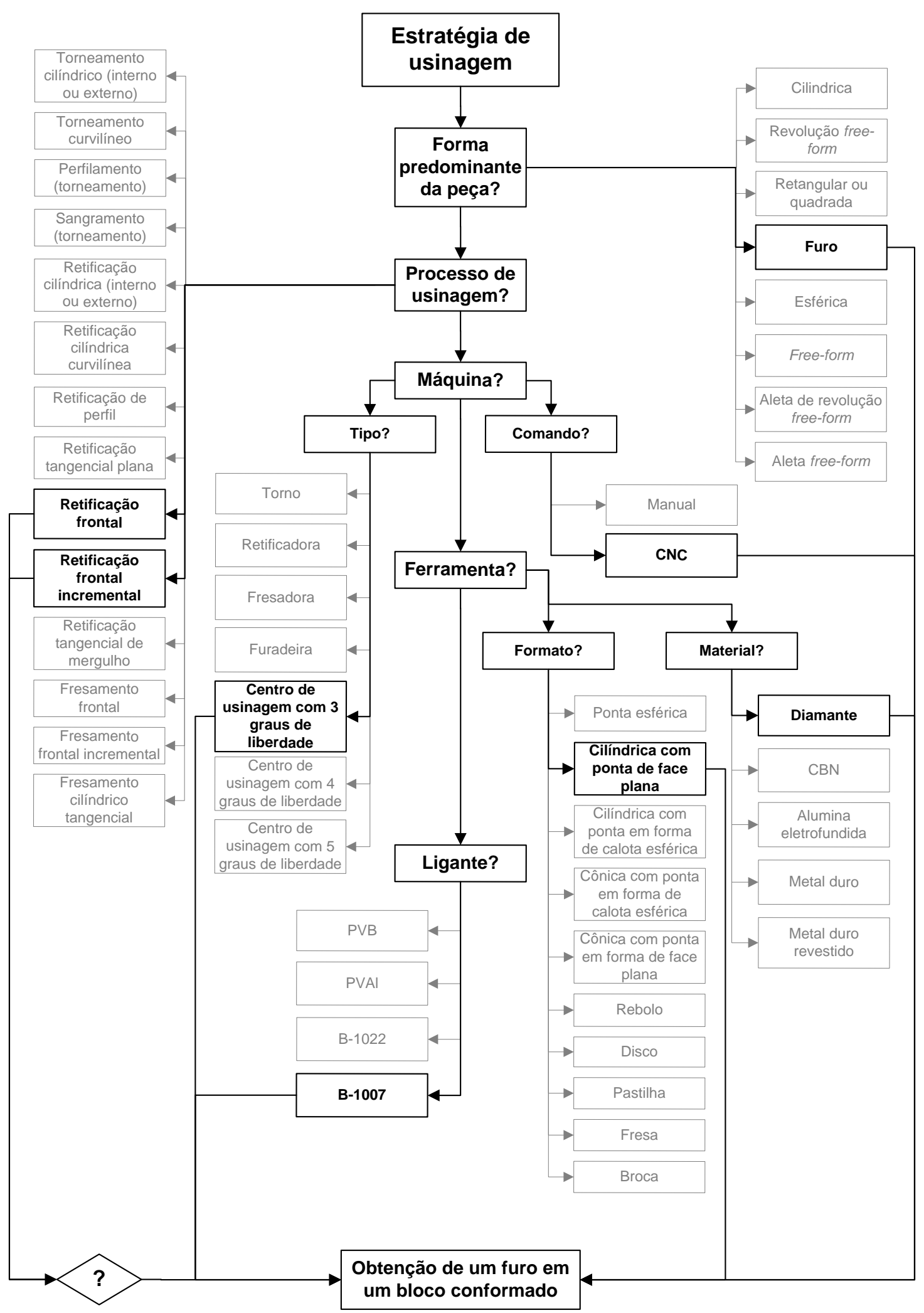

Figura 3.14 - Matriz de decisão para estratégia de usinagem em verde parcial para a obtenção de um furo em um bloco conformado. 


\subsubsection{Preparação dos corpos de prova}

Para obter furos de diâmetros $4 \mathrm{~mm}$, que foram usinados em verde utilizando a matriz de decisão para estratégia de usinagem em verde, foi utilizado um blank no

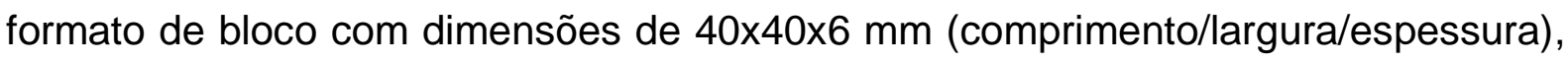
prensados uniaxialmente à $80 \mathrm{MPa}$ seguido de prensagem isostática a $200 \mathrm{MPa}$. $\mathrm{O}$ corpo foi tratado termicamente à $100^{\circ} \mathrm{C}$ por 12 horas, para homogeneizar e aliviar as tensões provenientes da prensagem. O bloco foi aderido, com cianoacrilato, na superfície de uma base de gesso, por duas extremidades de uma de suas faces planas $(40 \times 40 \mathrm{~mm})$, para permitir a usinagem. A base de gesso, por sua vez, possui um furo maior para cada furo que será executado, esse tem a finalidade de permitir a saída livre da ferramenta após a furação de toda a espessura do bloco conformado.

\subsubsection{Matéria prima e manufatura}

Como matéria prima foi empregada a Alumina Calcinada A1000-SG, (Almatis, Inc.) com diâmetro médio equivalente de partícula de 0,4 $\mu \mathrm{m}$, área superficial de 7,7 $\mathrm{mm}^{2} / \mathrm{g}$, $\rho_{\text {real: }}: 3,99 \mathrm{~g} / \mathrm{cm}^{3}$. Como ligante foi utilizado o ligante acrílico DURAMAX ${ }^{\mathrm{TM}} \mathrm{B}$ 1007 (2\% em peso) juntamente com o DURAMAX ${ }^{\mathrm{TM}}$ D-3005 (1\% em peso) em meio aquoso à 68 vol\% o qual foi misturado em moagem de bolas por 12 horas e, posteriormente, secos e granulados manualmente. A formulação foi denominada de acordo com a Tabela 3.11.

Tabela 3.11 - Denominação da formulação.

\begin{tabular}{|c|c|c|c|}
\hline Material & Ligante & Defloculante & Meio liquido \\
\hline D & B-1007 & D-3005 & Água destilada \\
\hline
\end{tabular}

\subsubsection{Seleção da ferramenta}

Duas ferramentas, com abrasivo de diamante, do formato descrito na matriz de decisão (pontas montada de formato cilíndrico com ponta de face plana) foram aplicadas, utilizando eletrodeposição metálica de níquel (ligante metálico) para a fixação dos grãos abrasivos. As dimensões das ferramentas escolhidas para o 
ensaio foram de $4 \times 6 \mathrm{~mm}$ (diâmetro/comprimento) para retificação frontal e 3×6 mm (diâmetro/comprimento) para retificação frontal incremental, ambas com abrasivo de granulometria \#80 mesh. A descrição das ferramentas de diamante gerada pelo fabricante foi, respectivamente, D PMD 040 D 181 e D PMD 030 D 181, ambas fabricadas pela empresa Master Diamond Ferramentas Ltda.

A utilização de um diâmetro menor de ferramenta, para a retificação frontal incremental, se deve ao fato desse processo gerar o furo por incrementos de profundidade até atingir a profundidade desejada na peça. Cada incremento é constituído de uma profundidade de corte, seguido de um avanço da ferramenta que descreve uma trajetória circular (orbital), enquanto a mesma remove material pela sua rotação, até completar uma volta completa.

As quantidades de incrementos necessários para obtenção de um furo dependem da profundidade de corte aplicada em relação à profundidade do furo. No caso de um furo passante, a quantidade de incremento está relacionada com a espessura da peça. Já o diâmetro do furo, está relacionado com o raio da ferramenta em relação ao raio da trajetória do avanço. No caso deste estudo, para a obtenção do furo de diâmetro $4 \mathrm{~mm}$, utilizando uma ferramenta de diâmetro $3 \mathrm{~mm}$, o raio da trajetória do avanço orbital da ferramenta deverá ser de $0,5 \mathrm{~mm}$, que somado ao raio de $1,5 \mathrm{~mm}$ da ferramenta, gera o raio de $2 \mathrm{~mm}(\varnothing 4 \mathrm{~mm})$ do furo.

\subsubsection{Planejamento e ensaios de usinagem}

Os experimentos de usinagem seguiram o planejamento apresentado na Tabela 3.12. Foi empregada um centro de usinagem de 3 graus de liberdade, como o especificado na matriz de decisão, equipado com um spindle (Precise) da Chapman Laboratory Ltda., de rolamentos esféricos de precisão com rotação de $36.500 \mathrm{rpm}$ e $500 \mathrm{~W}$ de potência, que gerou velocidade de corte $\left(v_{c}\right)$ de 7,64 (Ø 4 $\mathrm{mm}$ ) e $5,73 \mathrm{~m} / \mathrm{s}$ (Ø $3 \mathrm{~mm}$ ). Os parâmetros de usinagem foram obtidos a partir da avaliação das matrizes de decisão dos estudos anteriores e adequados ao processo de retificação frontal e retificação frontal incremental.

Com a ferramenta de diâmetro $4 \mathrm{~mm}$ foi aplicado o processo de retificação frontal, sendo o furo obtido com um avanço constante da ferramenta, até a saída da mesma pelo lado oposto do bloco. Já com a ferramenta de diâmetro $3 \mathrm{~mm}$ foi aplicado o processo de retificação frontal incremental, gerando o furo de $4 \mathrm{~mm}$, até a 
saída da mesma pelo lado oposto do bloco. Foi usinado, então, três furos com cada processo.

Tabela 3.12 - Planejamento experimental.

\begin{tabular}{|c|c|c|c|c|c|c|}
\hline $\begin{array}{l}\stackrel{0}{\bar{\varpi}} \\
\stackrel{\text { }}{\tilde{W}}\end{array}$ & 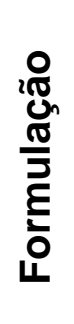 & 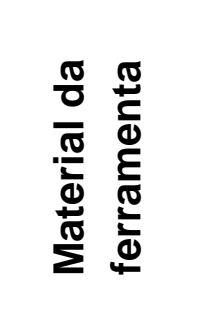 & 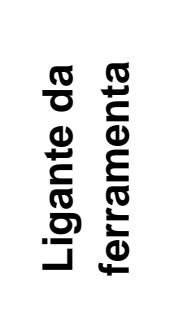 & 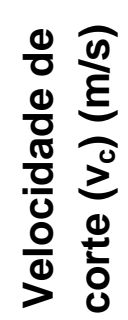 & 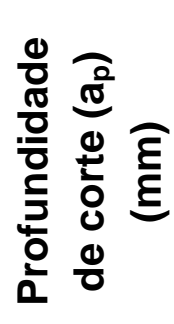 & 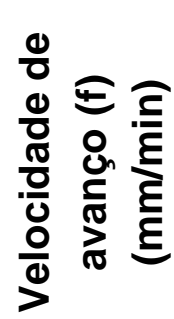 \\
\hline DDM-4-2,5 & \multirow{2}{*}{ D } & \multirow{2}{*}{ Diamante } & \multirow{2}{*}{ Metálico } & 7,64 & --- & 2,5 \\
\hline DDM-3-1-50 & & & & 5,73 & 1 & 50 \\
\hline
\end{tabular}

A montagem da bancada de ensaio é mostrada na Figura 3.15, onde se observa o centro de usinagem à esquerda junto a seu módulo de controle e o computador à direita. A Figura 3.16 (a) apresenta o desenho do planejamento da usinagem e a Figura 3.16 (b) a execução da usinagem para a obtenção das peças.

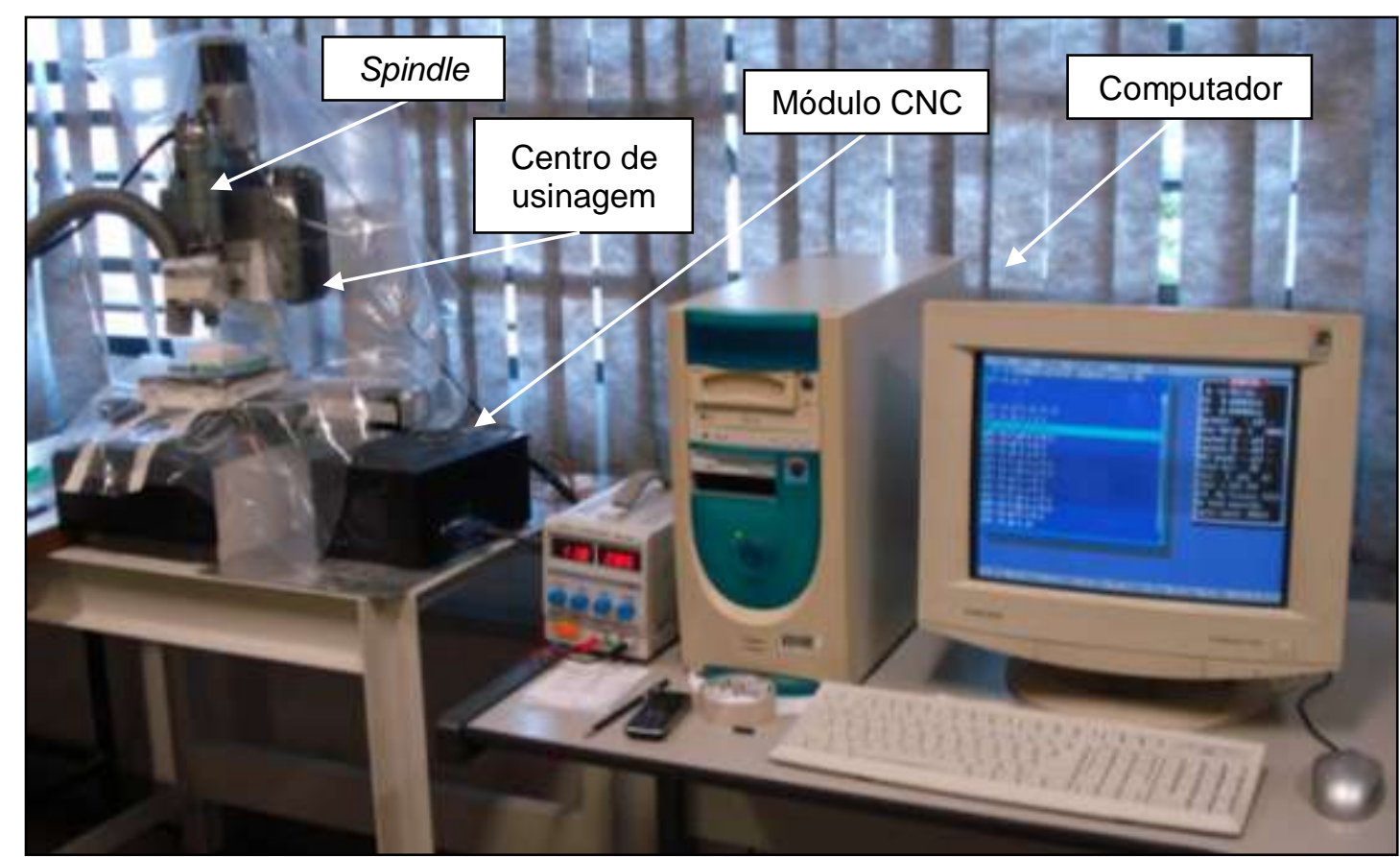

Figura 3.15 - Banco de ensaio para usinagem de tarugos de perfil redondo. 


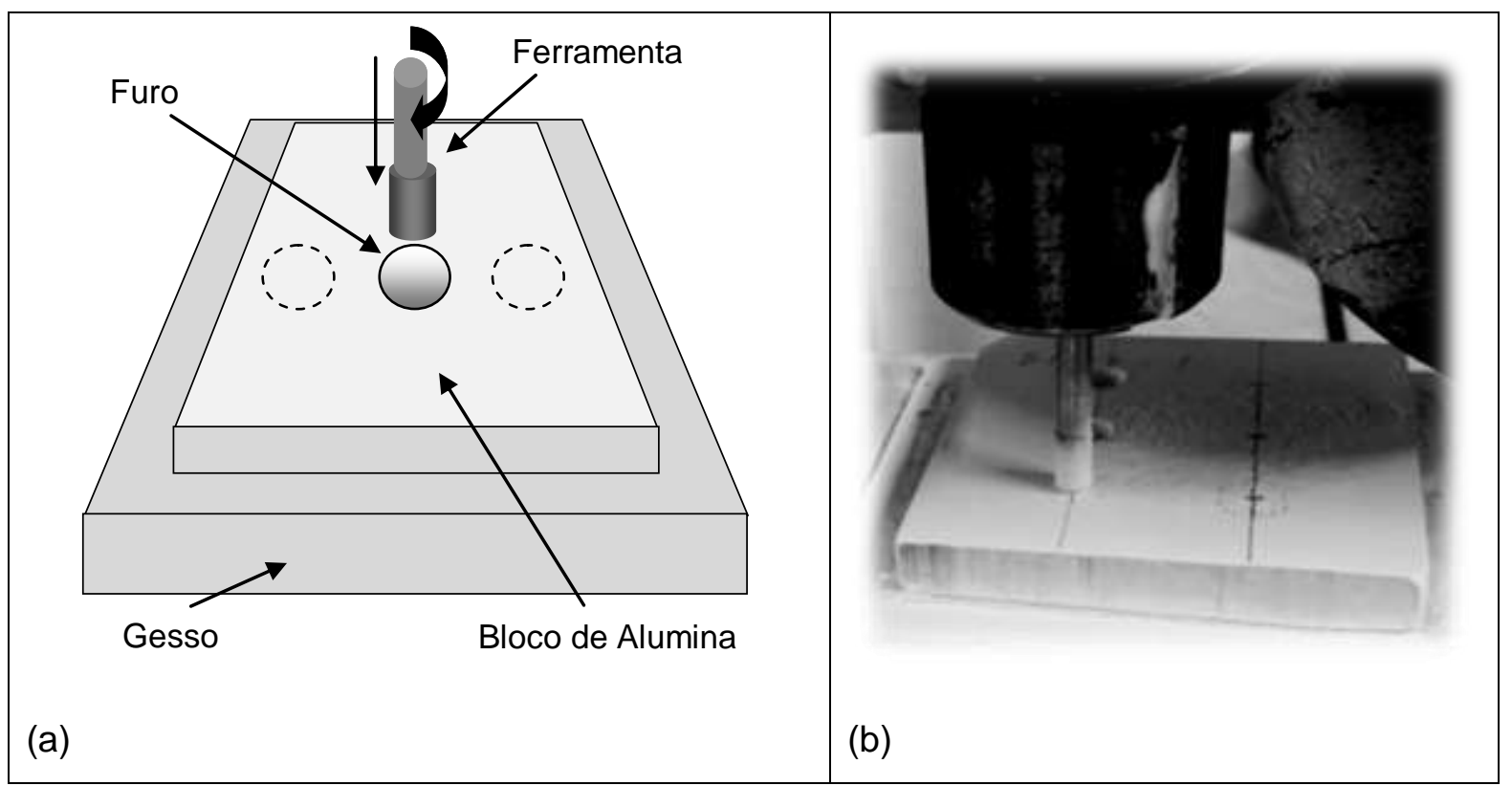

Figura 3.16 - Operação de furação do bloco, sendo (a) planejamento e (b) execução.

\subsubsection{Estratégia de usinagem em verde na fabricação de um implante dentário conceitual free-form}

Para a fabricação de um implante dentário conceitual free-form (Figura 3.17) a partir de um tarugo cônico conformado deve-se relacionar a forma do objeto em relação ao tipo de processo que pode ser aplicado a ele (Tabela 3.1) e, neste caso, se têm a retificação frontal e o fresamento frontal como opções. Neste ponto, a escolha pelo fresamento ou pela retificação fica em relação ao tipo de acabamento superficial obtido por cada processo. A retificação pode proporcionar menor rugosidade superficial comparado com o fresamento e a furação.

Para o efeito do estudo, o corpo-de-prova necessita do melhor acabamento possível alcançado pela usinagem, neste caso, fica a escolha pela retificação, que poderá ser realizada por uma retificadora ou um centro de usinagem, como é demonstrado na Tabela 3.2. A peça também tem a necessidade de precisão dimensional, que é melhor obtida por máquinas de controle CNC (Tabela 3.2), uma vez que não haverá a intervenção do homem nos posicionamentos da ferramenta na execução da usinagem. 


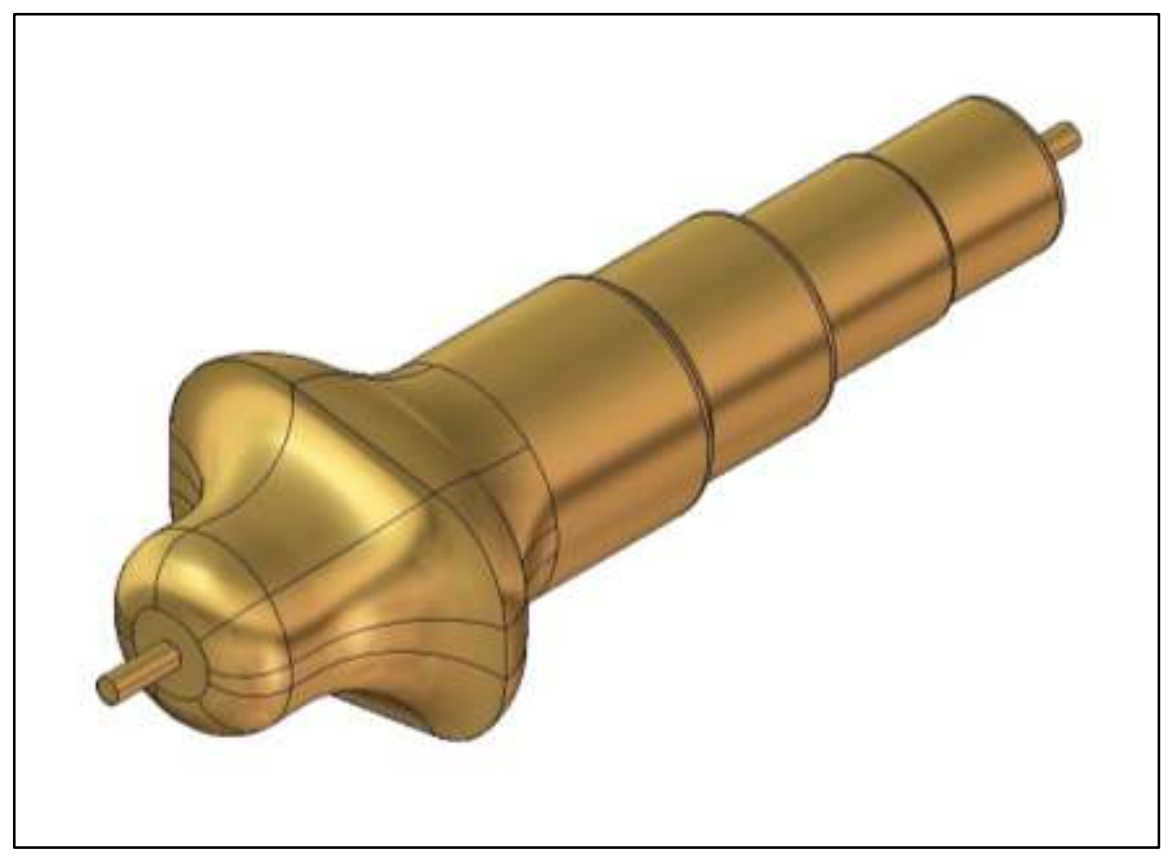

Figura 3.17 - Desenho em CAD do implante dentário conceitual free-form.

A escolha por uma retificadora CNC ou por um centro de usinagem depara em questões físicas de cada máquina. $O$ implante dentário conceitual free-form deverá ser obtido a partir de um tarugo cônico conformado em verde. Nesse caso, o formato com eixo de revolução assimétrico do pino não permite a utilização de uma retificadora $\mathrm{CNC}$, havendo a necessidade de um centro de usinagem com 4 graus de liberdade para a obtenção da mesma.

O processo de usinagem chamado de retificação frontal (Tabela 3.1) é o necessário para a obtenção do formato free-form, e permite o uso da ferramenta ponta montada. A forma da ferramenta, por sua vez, terá uma maior complexidade, cabendo a uma de ponta esférica (Tabela 3.3) ser a requerida para a usinagem.

A escolha do material da ferramenta (Tabela 3.3), do tipo de ligante (Tabela 3.4) e dos parâmetros de usinagem ficou a cargo dos resultados obtidos nas matrizes de decisão já estudadas. Utilizou o ligante B-1007, pressão de compactação de $200 \mathrm{MPa}$, ferramenta de diamante e parâmetros de usinagem equivalentes com a dimensão da ferramenta de corte.

Com a escolha destas variáveis é possível obter a matriz de decisão para estratégia de usinagem em verde na produção de um implante dentário free-form (Figura 3.18), tendo, desta forma, sua validação demonstrada com a usinagem em verde do implante. 


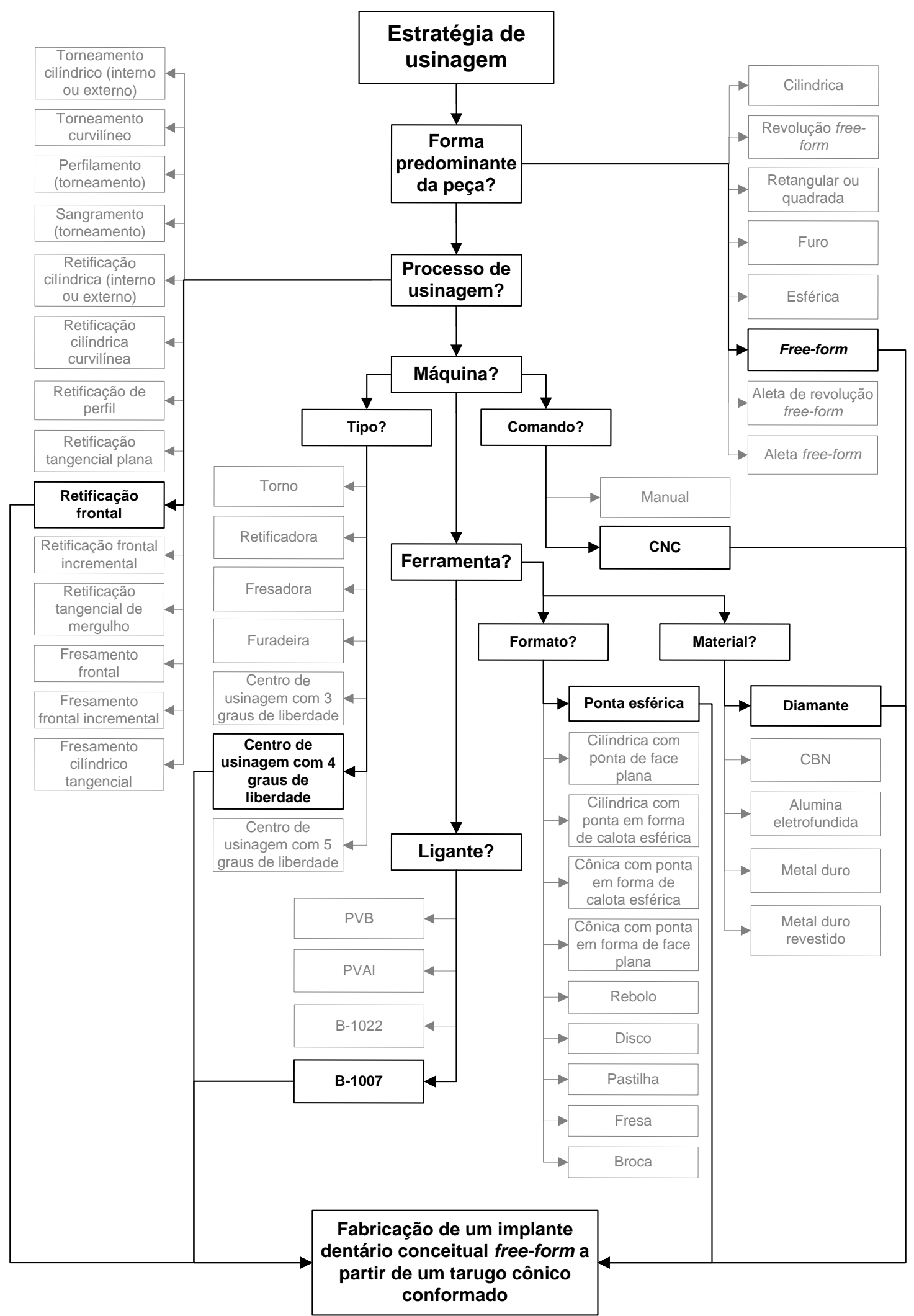

Figura 3.18 - Matriz de decisão para estratégia de usinagem em verde na fabricação de um implante dentário conceitual free-form a partir de um tarugo cônico conformado. 


\subsubsection{Preparação do corpo de prova}

Para obter o implante dentário conceitual, que é usinado em verde utilizando a matriz de decisão para estratégia de usinagem em verde, foi utilizado um blank no formato de tarugo cônico, com dimensões de $7 \times 4 \times 50 \mathrm{~mm}$ (base maior/base menor/comprimento), prensado isostaticamente a $200 \mathrm{MPa}$. As medidas do tarugo cônico são do formato e dimensões próximas ao do pino dentário, com o objetivo de não haver grande desperdício de material e diminuir o tempo de usinagem, como pode ser observado na Figura 3.19.

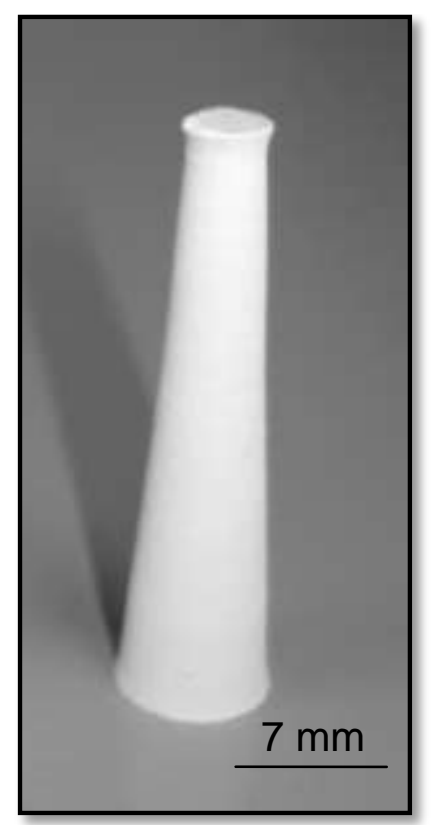

Figura 3.19 - Tarugo cônico de alumina em verde compactado a 200 MPa em prensa isostática.

O tarugo cônico foi tratado termicamente à $100^{\circ} \mathrm{C}$ por 12 horas, para homogeneizar e aliviar as tensões provenientes da prensagem. Posteriormente, foi aderido, com um adesivo térmico, na superfície de uma base metálica, que foi fixada a máquina, para permitir a usinagem.

Para a obtenção do tarugo cônico um molde foi projetado e fabricado exclusivamente para a prensagem. Na Figura 3.20 (a) é mostrado todas as partes constituintes do molde para prensagem isostática tipo wet-bag e na Figura 3.20 (b) o molde montado. 

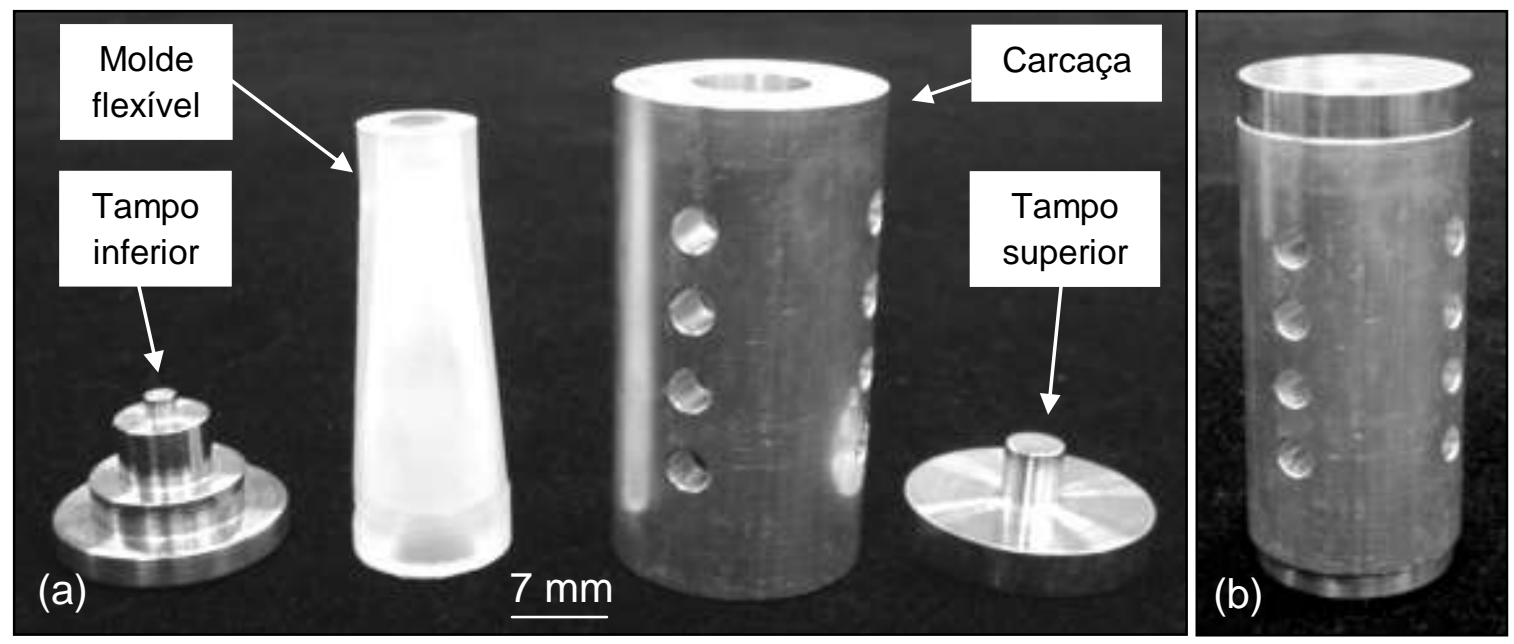

Figura 3.20 - Molde para prensagem isostática tipo wet-bag de um tarugo cônico. Em (a) partes do molde e (b) molde montado.

\subsubsection{Matéria prima e manufatura}

Como matéria prima foi empregada a Alumina Calcinada A1000-SG, (Almatis, Inc.) com diâmetro médio equivalente de partícula de 0,4 $\mu \mathrm{m}$, área superficial de 7,7 $\mathrm{mm}^{2} / \mathrm{g}$, $\rho_{\text {real }}: 3,99 \mathrm{~g} / \mathrm{cm}^{3}$. Como ligante foi utilizado o ligante acrílico DURAMAX ${ }^{\mathrm{TM}} \mathrm{B}-$ 1007 (2 \% em peso) juntamente com o DURAMAX ${ }^{\mathrm{TM}}$ D-3005 (1 \% em peso) em meio aquoso à 68 vol\% o qual foi misturado em moagem de bolas por 12 horas e, posteriormente, secos e granulados manualmente. A formulação foi denominada de acordo com a Tabela 3.13.

Tabela 3.13 - Denominação da formulação.

\begin{tabular}{|c|c|c|c|}
\hline Material & Ligante & Defloculante & Meio liquido \\
\hline D & B-1007 & D-3005 & Água destilada \\
\hline
\end{tabular}

\subsubsection{Seleção da ferramenta}

Uma ferramenta, com abrasivo de diamante, do formato descrito na matriz de decisão (ponta montada de ponta esférica) foi aplicada, utilizando eletrodeposição metálica de níquel (ligante metálico) para a fixação dos grãos abrasivos. Sua dimensão escolhida, para atingir todos os detalhes do formato free-form do implante dentário na usinagem, foi de $1 \mathrm{~mm}$ de diâmetro. A granulometria do abrasivo utilizado na ferramenta foi de \#120 mesh, pois, segundo o fabricante, é o tamanho de partícula que permite ser aplicado a esse formato de ferramenta com diâmetro de 
1,0 mm. A descrição da ferramenta de diamante gerada pelo fabricante foi PMG001 D126 e foi fabricada pela empresa Master Diamond Ferramentas Ltda.

\subsubsection{Planejamento e ensaios de usinagem}

Os experimentos de usinagem seguiram o planejamento apresentado na Tabela 3.14. Foi empregada um mini centro de usinagem de 4 graus de liberdade (MDX-40) da Roland DG Ltda. (Figura 21), equipado com um spindle de rolamentos esféricos de precisão com rotação de $15.000 \mathrm{rpm}$, que gerou velocidade de corte $\left(\mathrm{v}_{\mathrm{c}}\right)$ de $0,78 \mathrm{~m} / \mathrm{s}$. Os parâmetros de usinagem foram obtidos a partir da avaliação das matrizes de decisão e adequados ao processo de retificação frontal, e foram divididos em parâmetros para operação de desbaste e acabamento. Sendo que para a operação de acabamento foi aplicado valores menores de largura de corte e profundidade de corte, como já se sugere neste tipo de operação.

Tabela 3.14 - Planejamento experimental.

\begin{tabular}{|c|c|c|c|c|}
\hline Operação & $\begin{array}{c}\text { Largura de } \\
\text { corte }\left(\mathbf{a}_{\mathbf{e}}\right) \\
(\mathbf{m m})\end{array}$ & $\begin{array}{c}\text { Profundidade } \\
\text { de corte }\left(\mathbf{a}_{\mathbf{p}}\right) \\
(\mathbf{m m})\end{array}$ & $\begin{array}{c}\text { Velocidade } \\
\text { de corte }\left(\mathbf{v}_{\mathbf{c}}\right) \\
(\mathbf{m} / \mathbf{s})\end{array}$ & $\begin{array}{c}\text { Velocidade } \\
\text { de avanço } \\
\left(\mathbf{v}_{\mathbf{f}}\right)(\mathbf{m m} / \mathbf{s})\end{array}$ \\
\hline Desbaste & 0,3 & 0,2 & 0,78 & 1 \\
\hline Acabamento & 0,1 & 0,1 & 0 & 1 \\
\hline
\end{tabular}

A Figura 3.22 demonstra o processo de usinagem do implante dentário conceitual. Nela observa-se o spindle, onde está fixado a ferramenta, e o quarto grau de liberdade, onde o tarugo cônico, aderido à base metálica, está fixado.

$O$ desenho em CAD do implante dentário free-form, convertido no formato STL, foi carregado no computador do mini centro de usinagem, o qual possui um softwear de CAM próprio, que interpreta o arquivo STL do desenho e cria a rotina de usinagem. Em cada extremidade do desenho do implante um pequeno cilindro foi adicionado (Figura 3.17). $O$ intuito foi de forçar o softwear CAM a gerar a rotina de usinagem além do comprimento do desenho, permitindo a usinagem de suas extremidades. Caso contrário, a rotina de usinagem era apenas gerada até atingir o comprimento do implante, que não permitia a sua usinagem por completo.

A rotina de usinagem, que pode realizar as operações de desbaste ou acabamento, foi divida em cinco etapas para evitar uma eventual quebra do implante 
durante a usinagem. Este procedimento se torna importante uma vez que toda a operação foi realizada com o tarugo em balanço, ou seja, fixado à máquina apenas por uma de suas pontas de face plana, no caso, a de maior secção transversal.

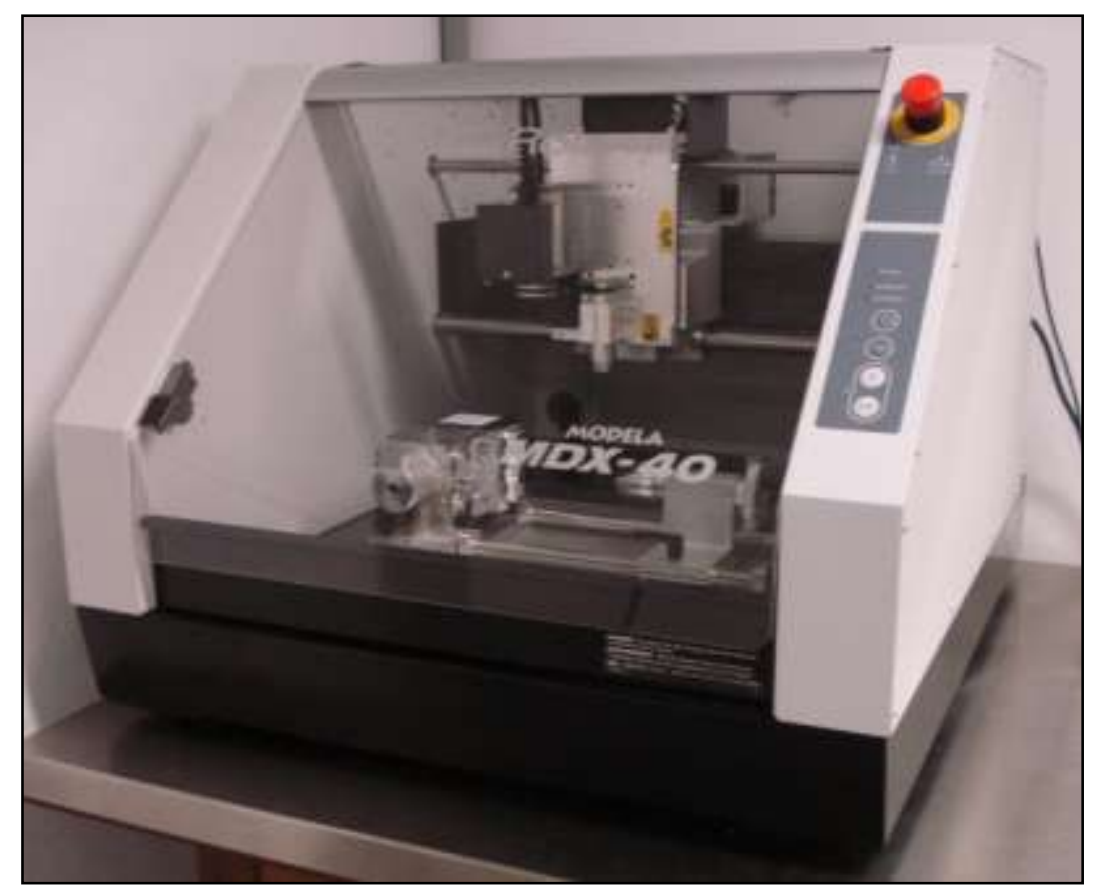

Figura 3.21 - Imagem do mini centro de usinagem (MDX-40) da Roland DG Ltda.

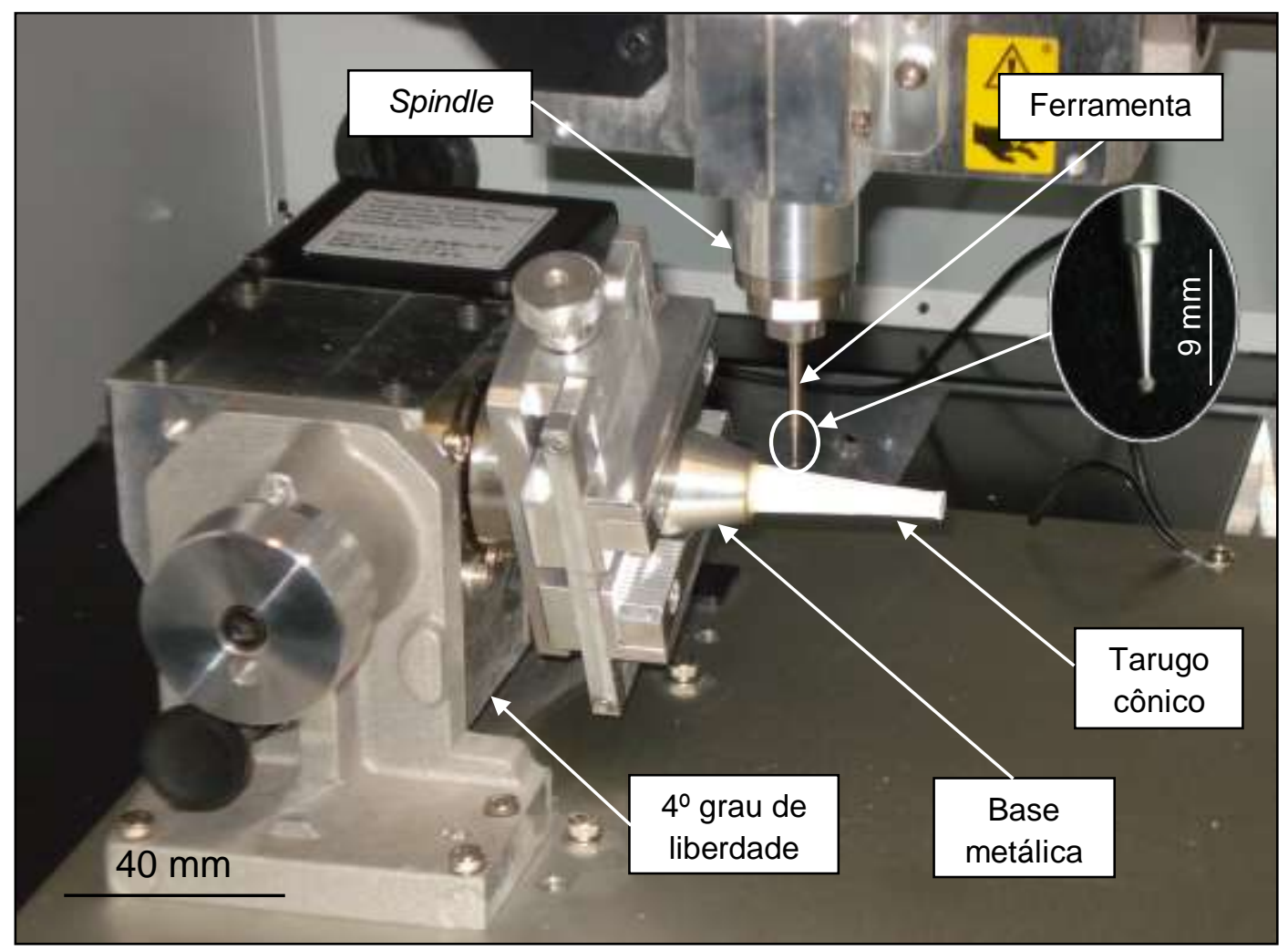

Figura 3.22 - Imagem do habitáculo de usinagem da máquina. 
Com a primeira etapa (Figura 3.23), foi realizada a usinagem do corpo inferior do implante com a operação de desbaste. Esta permitiu a obtenção do formato do corpo inferior, porém, com um sobrematerial de $0,1 \mathrm{~mm}$ e a remoção do excesso de comprimento do tarugo. Já com a segunda etapa (Figura 3.24), foi realizada a usinagem do corpo inferior do implante com a operação de acabamento, deixando-o na medida final e com o acabamento esperado.

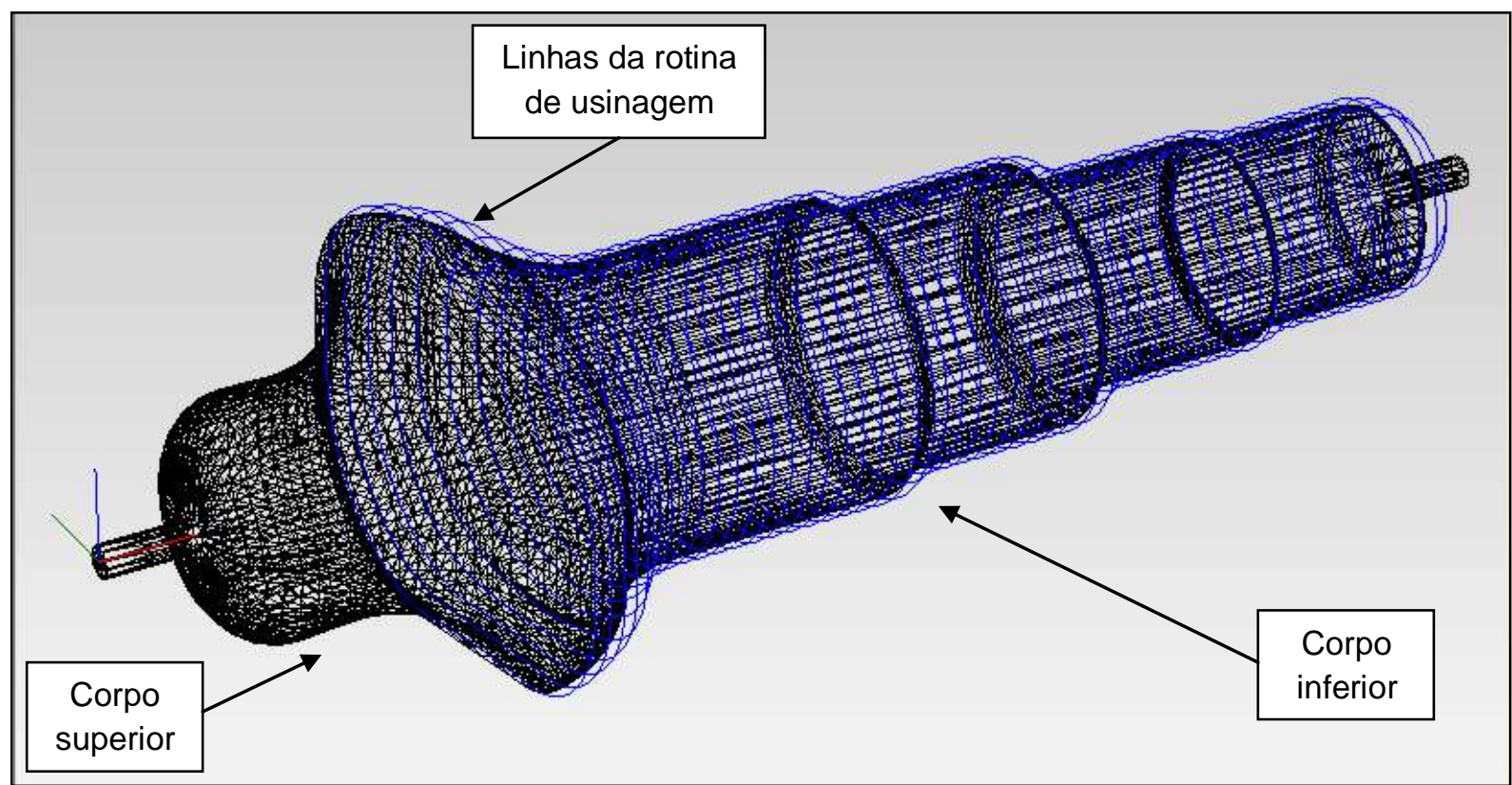

Figura 3.23 - Primeira etapa, operação de desbaste do corpo inferior do implante conceitual.

$\mathrm{Na}$ terceira etapa (Figura 3.25), foi realizada a usinagem do corpo superior do implante com a operação de desbaste, porém, sem a usinagem da ponta do corpo superior do implante. Esta permitiu a obtenção do formato do corpo superior, também, com um sobrematerial de $0,1 \mathrm{~mm}$. Já com a quarta etapa (Figura 3.26), foi realizada a usinagem do corpo superior do implante com a operação de acabamento, deixando-o na medida final e com o acabamento esperado, porém, ainda sem a usinagem da ponta do corpo superior do implante.

Com a quinta e última etapa (Figura 3.27) foi realizado a usinagem da ponta do corpo superior do implante com a operação de acabamento. A usinagem foi realizada até que o material restante, entre o tarugo e o implante, não resistiu à força de corte e se rompeu. Posteriormente o implante foi sinterizado conforme a curva do gráfico da Figura 3.6. 


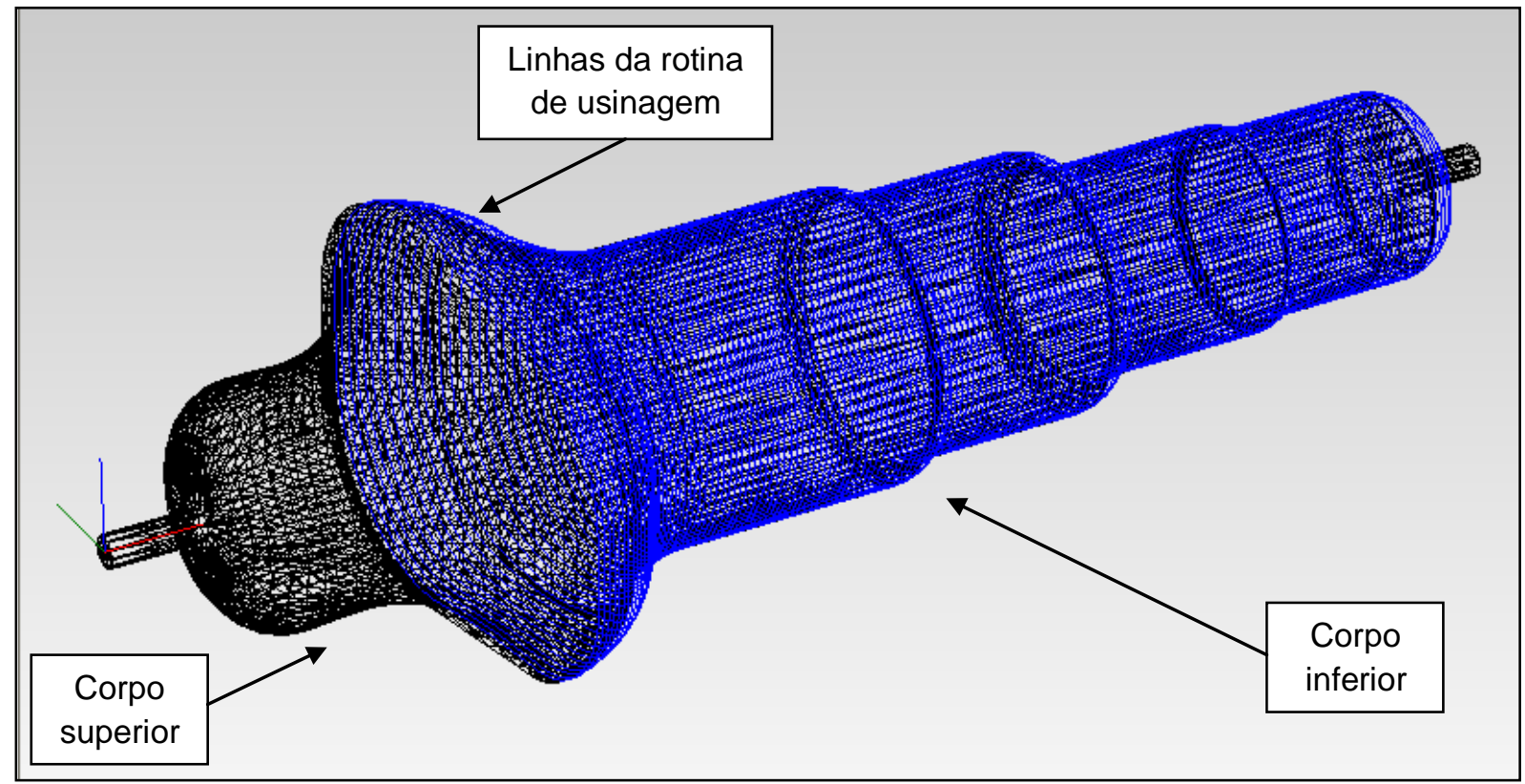

Figura 3.24 - Segunda etapa, operação de acabamento do corpo inferior do implante conceitual.

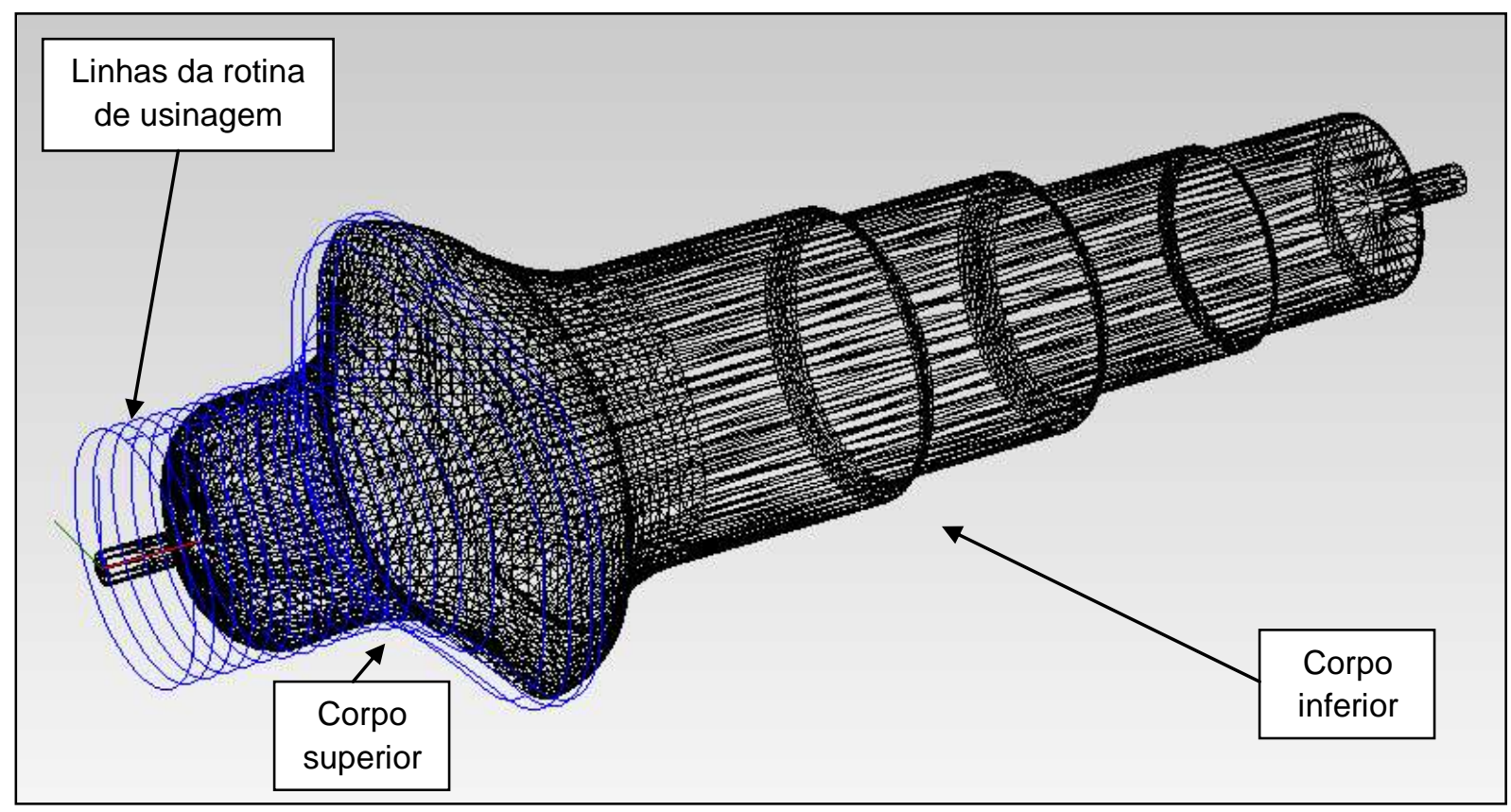

Figura 3.25 - Terceira etapa, operação de desbaste do corpo superior do implante conceitual. 


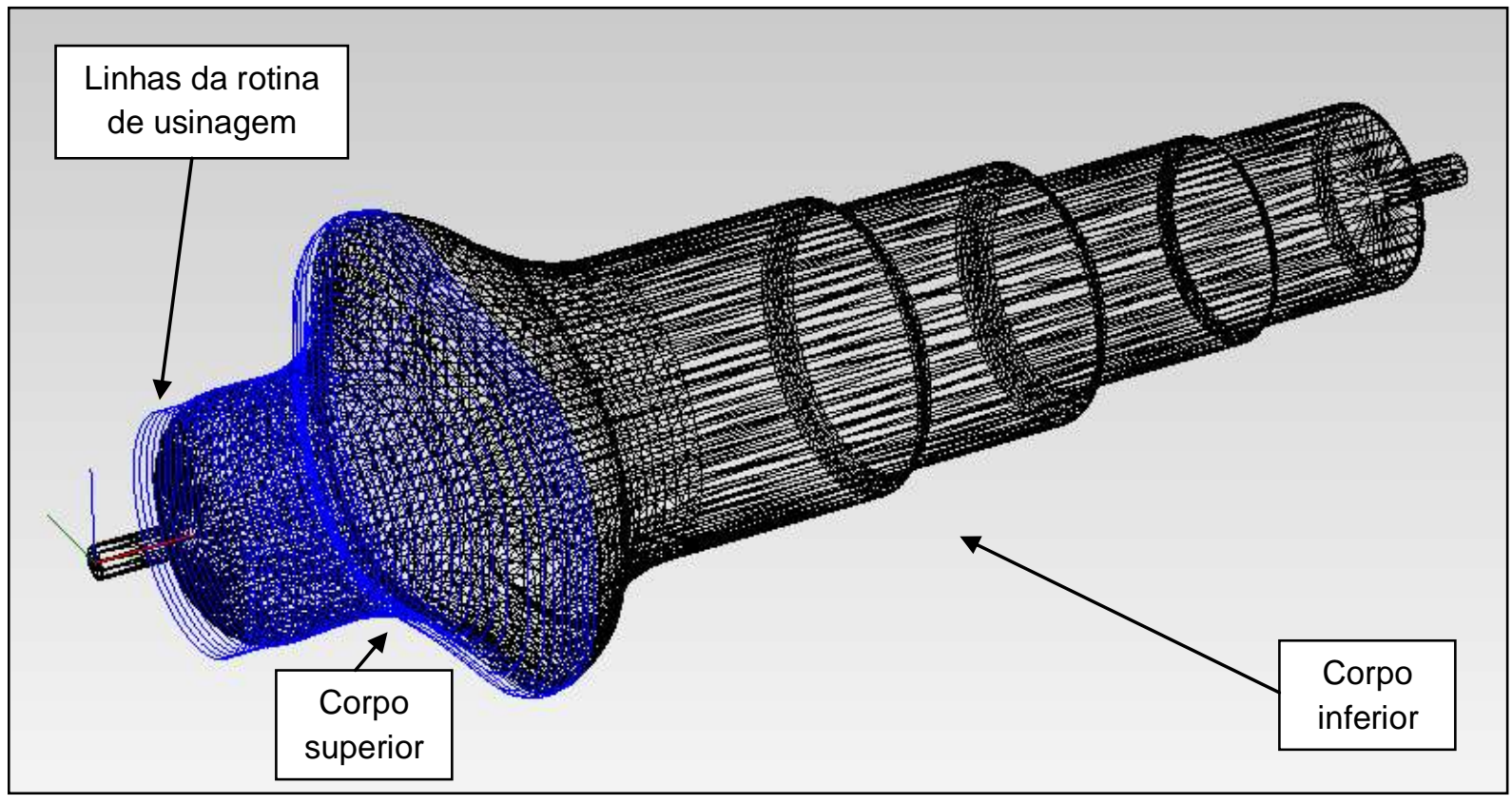

Figura 3.26 - Quarta etapa, operação de acabamento do corpo superior do implante conceitual.

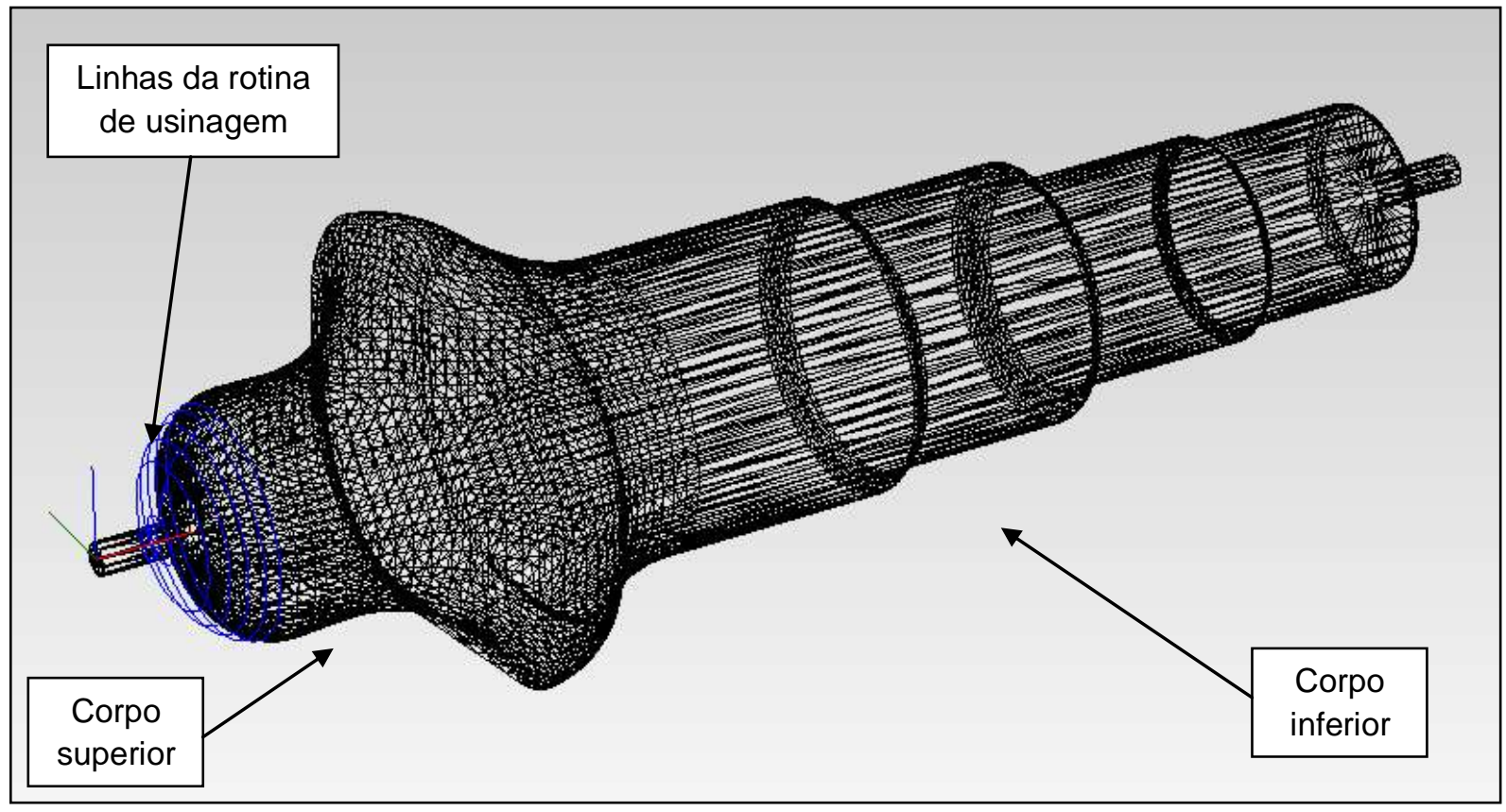

Figura 3.27 - Quinta etapa, operação de acabamento da ponta do corpo superior do implante conceitual. 



\section{RESULTADOS E DISCUSSÃO}

Foram realizados ensaios em barras, cilindros e furos, onde se obteve resultados de avaliação dos ligantes: PVAl, PVB e os acrílicos B-1022 e B-1007, torque de usinagem, principais ferramentas com partículas de diamante, CBN e alumina eletrofundida e processos de usinagem.

\subsection{Resultados do estudo de caso de usinagem em verde}

Os resultados dos ensaios obtidos, pela aplicação das matrizes de decisões para estratégia de usinagem em verde, serão discutidos nos cinco tópicos principais abaixo.

\subsubsection{Resultados da estratégia de usinagem em verde na fabricação de uma barra com perfil de seção retangular (Ensaio preliminar)}

Os resultados foram divididos em dois grupos principais, relativos ao desempenho do corte e a resistência mecânica que considerou a introdução de defeitos superficiais. A Figura 4.1 mostra dois tipos de defeitos observados na aresta superior devido a falta de ancoramento superficial e na aresta inferior devido a fratura da separação da barra durante a usinagem do bloco aderido. Amostras com defeitos desta natureza não foram analisadas.

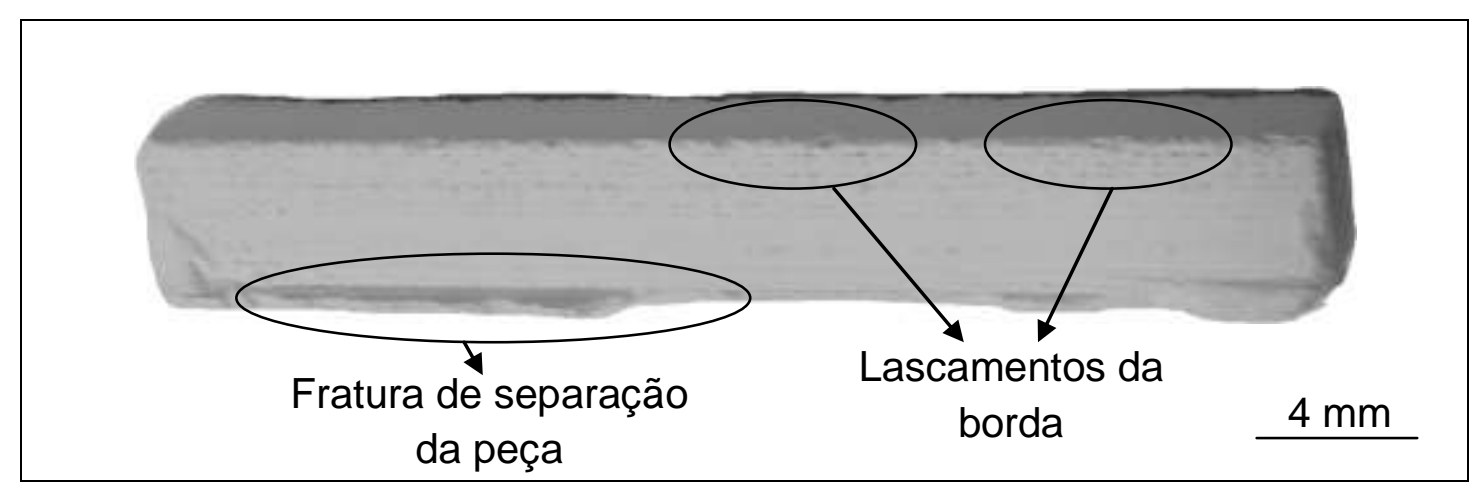

Figura 4.1 - Defeitos de borda ocorridos durante a usinagem.

Relativo às perdas de propriedades mecânicas, a Figura 4.2 mostra que com o aumento da velocidade de avanço, houve para as peças com ligante PVB e ferramenta com diamante, uma perda de propriedade mecânica, isto foi devido à introdução de defeitos na superfície de acordo com o aumento da rugosidade média aritmética (Ra) apresentada pela Figura 4.3. 
Já as barras processadas com PVB e usinadas com ferramentas de CBN, apresentaram a ocorrência inversa, ou seja, houve melhora das propriedades mecânicas (Figura 4.2/PVB-CBN) com diminuição da rugosidade (Figura 4.3/PVB$\mathrm{CBN}$ ), este resultado mostra a forte dependência do tipo do material abrasivo na usinagem em verde. Neste experimento foram encontrados os melhores valores de resistência a flexão, da ordem de $190 \mathrm{MPa}$.

Amostras processadas com PVAL tiveram os piores valores de resistência mecânica (Figura 4.2/PVAl-Diamante) onde não foi verificada influência significativa da velocidade de avanço (f) na faixa analisada, porém tiveram queda de rugosidade, este efeito pode ser atribuído ao alto empastamento observado na ferramenta, que removeu material com menos riscamento, porém impondo grande esforço indicando uma desvantagem do PVAI como ligante (Figura 4.3/PVAl-Diamante). Esse baixo desempenho da propriedade mecânica pode ser atribuído, também, a menor rugosidade das arestas dos grãos de diamante em relação ao de CBN, o que dificultou a remoção de material da peça.

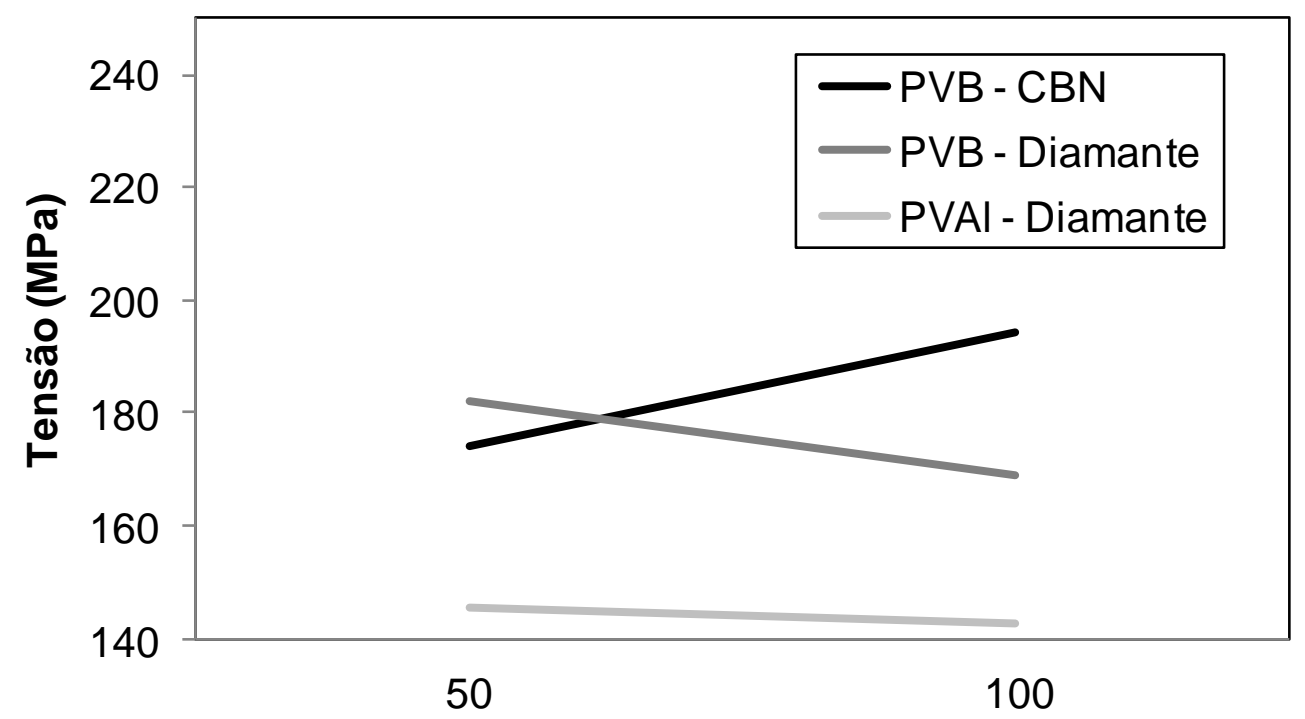

Velocidade de avanço ( $\mathrm{mm} / \mathrm{min})$

Figura 4.2 - Tensões máximas de ruptura obtidas em função do material da ferramenta e do ligante utilizados. 


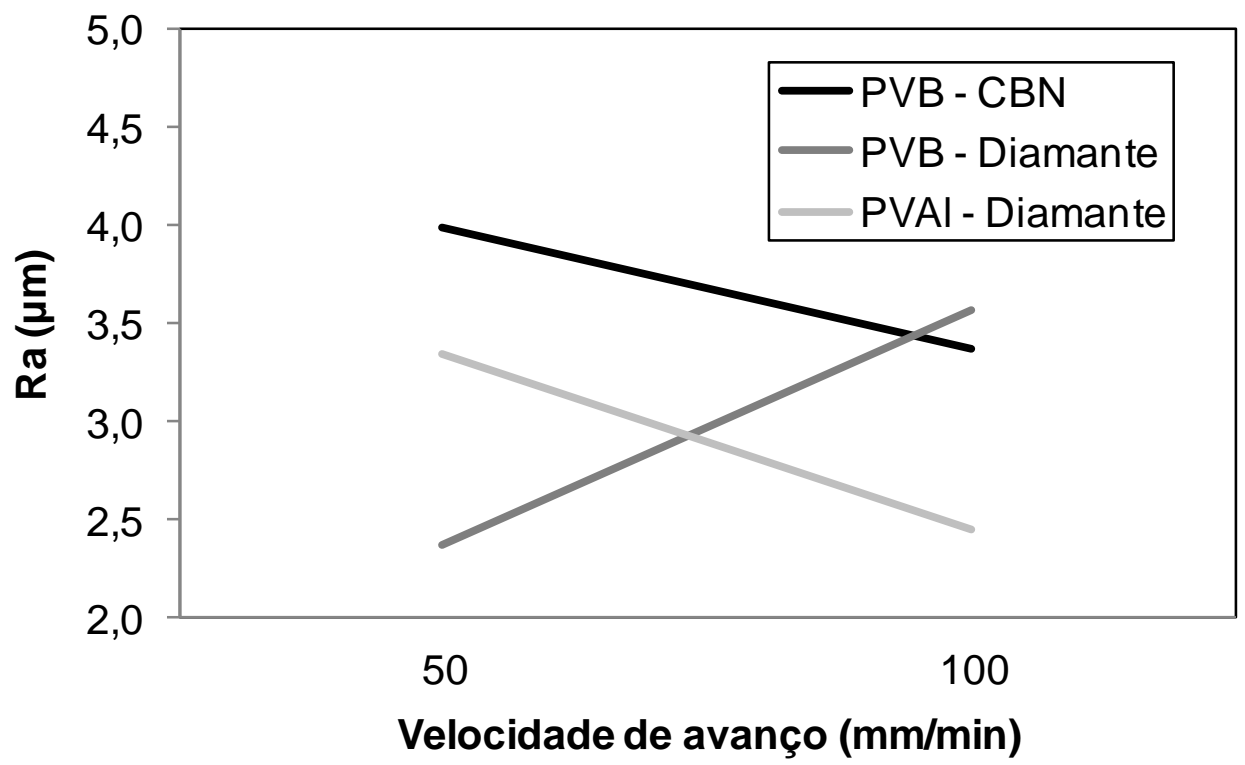

Figura 4.3 - Rugosidade média aritmética $(\mathrm{Ra})$ obtida em função do material da peça e do ligante utilizados.

\subsubsection{Resolução da estratégia de usinagem em verde na fabricação de uma barra com perfil retangular}

Este estudo preliminar indica vantagem no emprego de ligante PVB com a ferramenta de material abrasivo de CBN e parâmetros de corte de $15 \mathrm{~m} / \mathrm{s}$, profundidade de $0,5 \mathrm{~mm}$ e avanço de $100 \mathrm{~mm} / \mathrm{min}$, sendo observados valores extremos de $190 \mathrm{MPa}$ contra $145 \mathrm{MPa}$, quando utilizado o ligante PVAl e o abrasivo de diamante na ferramenta.

Dessa forma pode ser orientada pela resolução da matriz de decisão para estratégia de usinagem em verde na fabricação de barras com perfil retangular, como é demonstrada na Figura 4.4. 


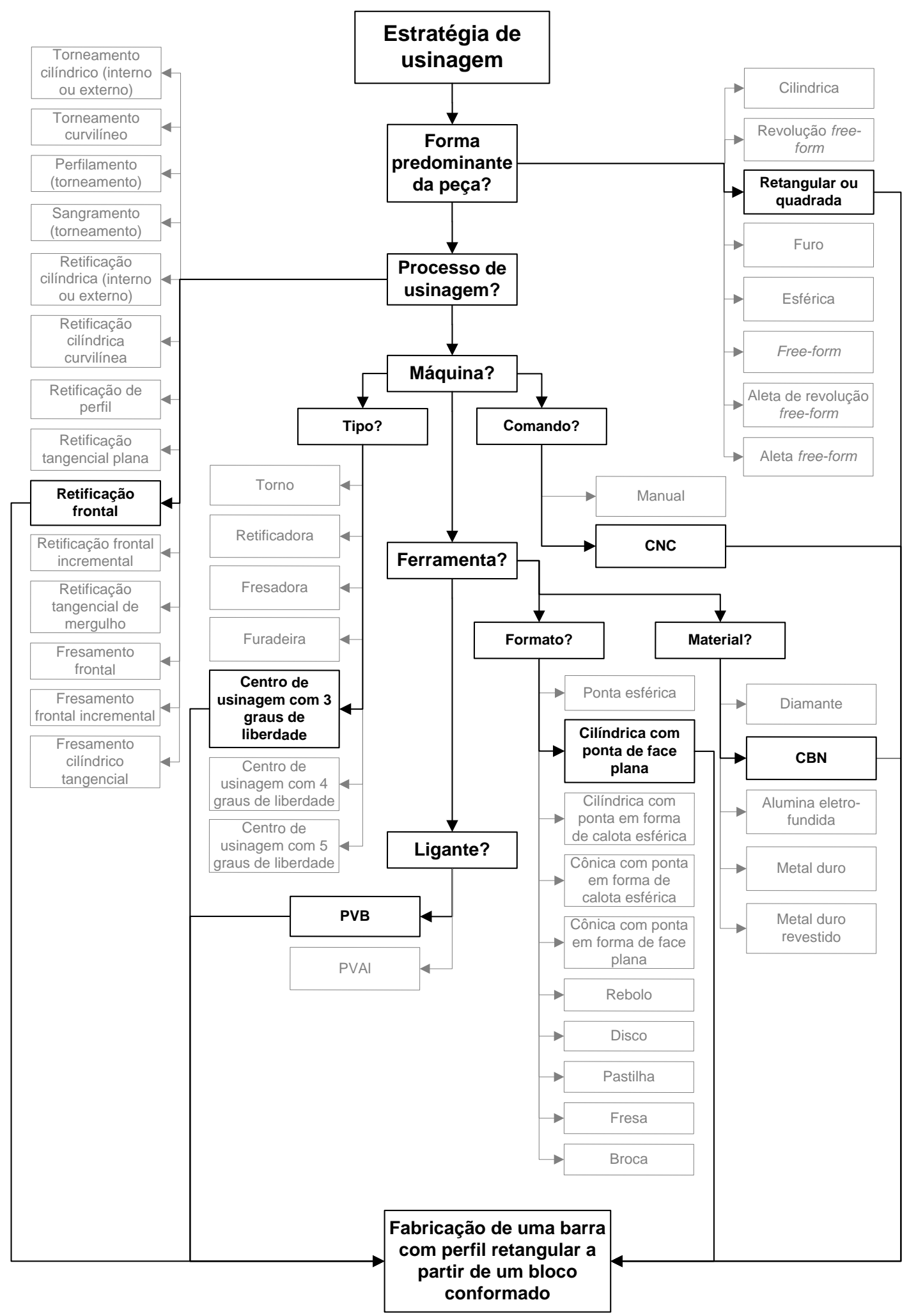

Figura 4.4 - Matriz de decisão para estratégia de usinagem em verde na fabricação de uma barra com perfil de seção retangular a partir de um bloco conformado. 


\subsubsection{Resultados da estratégia de usinagem em verde na fabricação de um cilindro}

Os resultados adquiridos foram divididos em três grupos principais relativos a resistência mecânica em verde do tarugo bruto e sinterizado após usinagem, ao desempenho do corte e ao torque de usinagem.

O ensaio de ruptura a flexão para os tarugos brutos em verde demonstrou resultados diferentes para cada tipo de ligante (Figura 4.5). Sendo que o ligante PVAl apresentou o menor resultado de resistência mecânica, seguido pelo PVB, B1007 até o ligante B-1022, o qual apresentou a maior resistência mecânica a flexão em verde de todos o ligantes. Com esta análise, os ligantes acrílicos demonstram ser mais eficientes, com valores de resistências aproximadamente duplicados em relação ao PVAl e PVB. O aumento da pressão de compactação agiu de forma positiva, e promoveu o aumento da resistência mecânica a flexão em verde dos quatro tipos de ligantes.

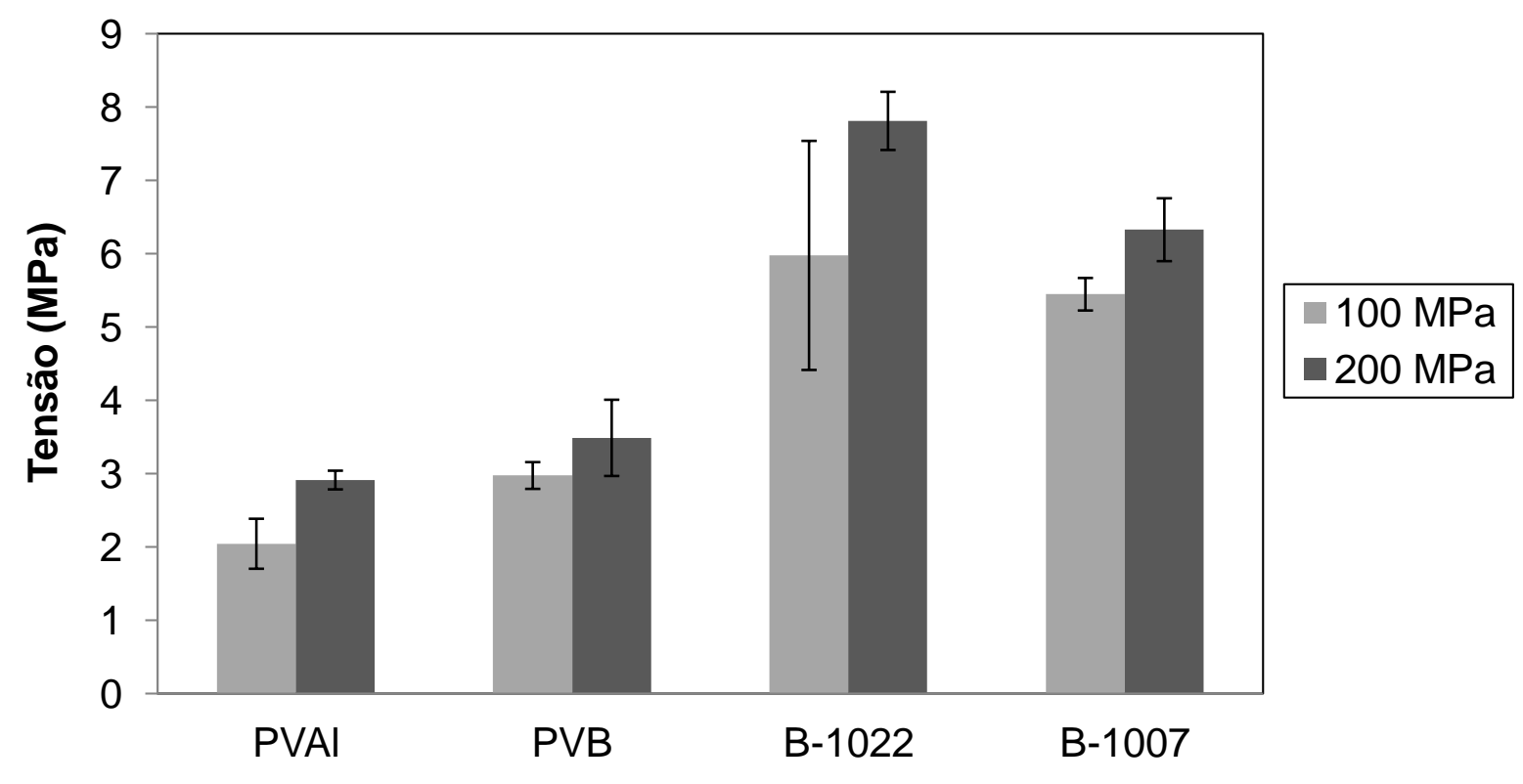

Ligante (2 \% em peso)

Figura 4.5 - Tensões máximas de ruptura em verde obtidas em função do ligante utilizado e da pressão de compactação.

A Figura 4.6 mostra o lascamento de borda, na região circulada, nos corposde-prova prensados a $100 \mathrm{MPa}$ em função do tipo de ligante. Pode ser observado que o material utilizando o ligante PVAl foi o que apresentou maior lascamento da borda, seguido do PVB, B-1022 e terminando com o B-1007, o qual apresentou 
menos lascamento. Defeito dessa natureza causa acabamento inferior na peça final, podendo levar ao descarte da mesma, caso não seja atingido os requisitos de projeto.
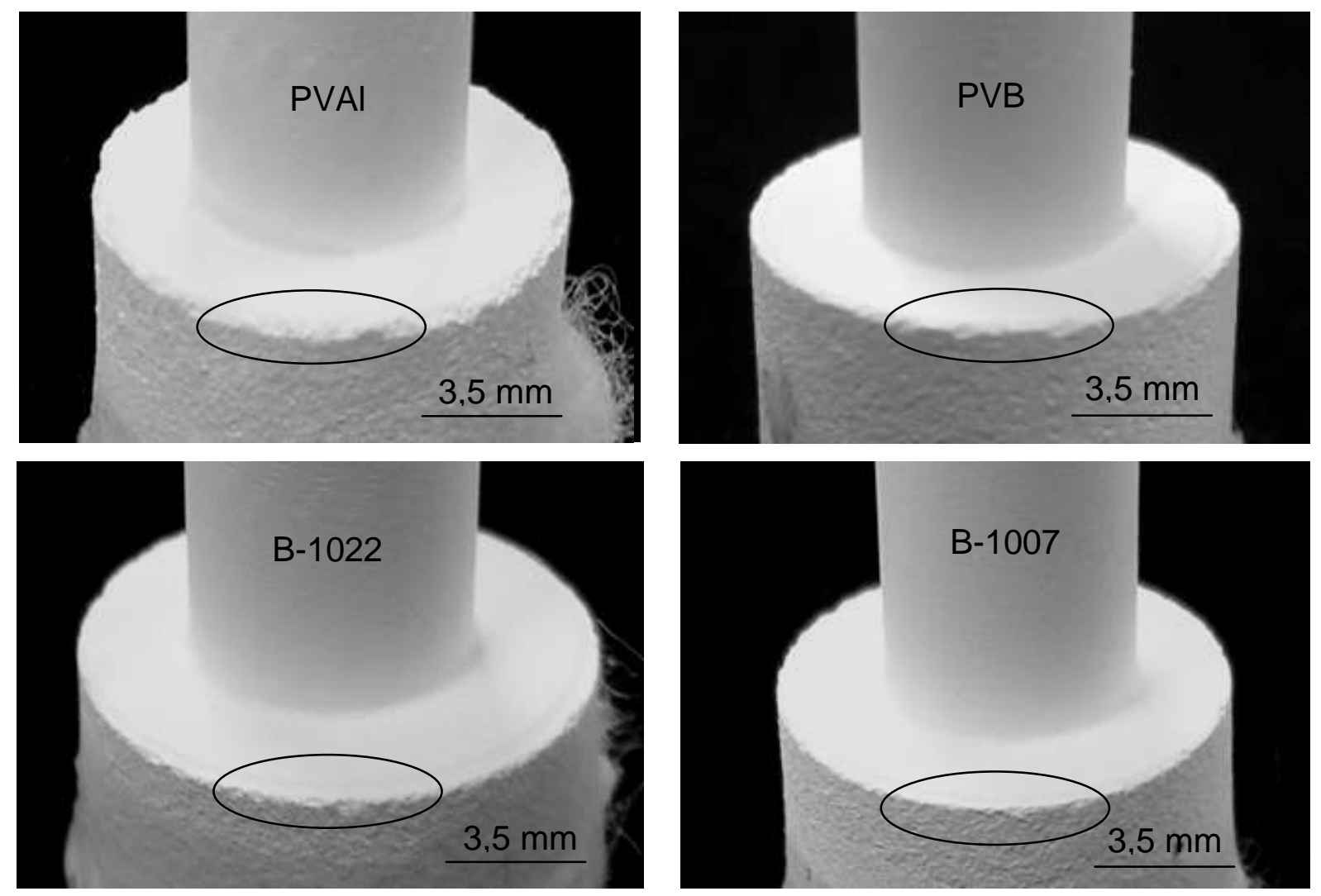

Figura 4.6 - Lascamentos de borda ocorridos durante a usinagem, em função do tipo de ligante, dos compactados prensados a $100 \mathrm{MPa}$.

A prensagem a $200 \mathrm{MPa}$ promoveu uma diminuição do lascamento de borda de uma forma geral, região circulada, para todos os ligantes (Figura 4.7), sendo observado uma maior diminuição para os ligantes PVAl e PVB quando comparados as imagens das Figuras $4.6 \mathrm{com}$ as da Figura 4.7. O aumento da resistência mecânica em verde, causado pelo aumento da pressão de compactação, seria 0 responsável pela diminuição dos lascamentos de borda devido ao aumento da coesão entre as partículas de alumina com o ligante. Sendo de suma importância para o acabamento final de uma peça cerâmica.

A retração linear das peças (Figura 4.8) demonstrou ser influenciada pelo tipo de ligante, sendo o menor valor observado para o ligante PVAl seguido do B-1007, B-1022, sendo obtido o maior valor para o ligante PVB. Quanto menor o valor observado menor redução de tamanho foi sofrida pela peça, o que possibilita um 
menor sobrematerial na fabricação de uma peça qualquer. Neste caso os corpos-deprova que menos diminuíram de tamanho foram os com ligante PVAL e os que mais sofreram diminuição foram os com o ligante PVB. Os ligantes acrílicos tiveram valores muito próximos ao PVAl, demonstrando serem igualmente eficientes. Também pode ser observado que a retração linear respondeu positivamente ao aumento da pressão de compactação (100 MPa para $200 \mathrm{MPa}$ ), sendo observada uma diminuição de seus valores, principalmente para o ligante PVB, seguido do PVAl e B-1007, porém, apenas não observado para o ligante B-1022.
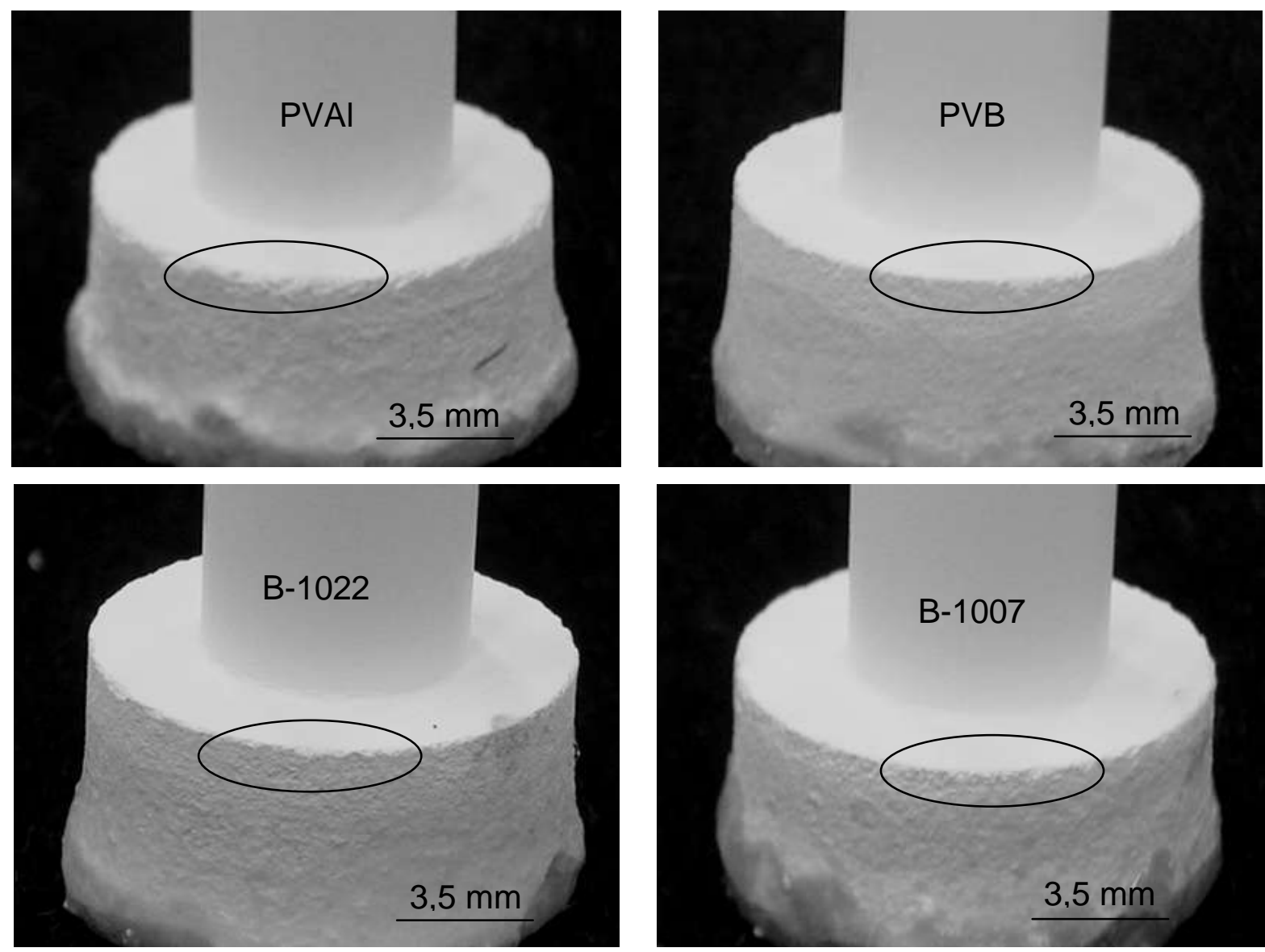

Figura 4.7 - Lascamentos de borda ocorridos durante a usinagem, em função do tipo de ligante, dos compactados prensados a $200 \mathrm{MPa}$.

Os ligantes também demonstraram ser influentes nas medições de torque da usinagem, sendo o menor valor observado para o ligante PVAL, seguido do PVB, B1007, sendo obtido o maior valor para o ligante acrílico B-1022 (Figura 4.9). Dessa forma, foi necessário maior esforço para a usinagem dos ligantes acrílicos em relação ao PVB e ao PVAI. O aumento da pressão de compactação (100 MPa para $200 \mathrm{MPa}$ ) promoveu o aumento do torque de usinagem para os ligantes PVAl, PVB 
e B-1007, sendo apenas observada uma diminuição para o ligante B-1022. Uma relação pode ser feita com a tensão de ruptura em verde, sendo observado aumento do torque com o aumento da resistência mecânica.

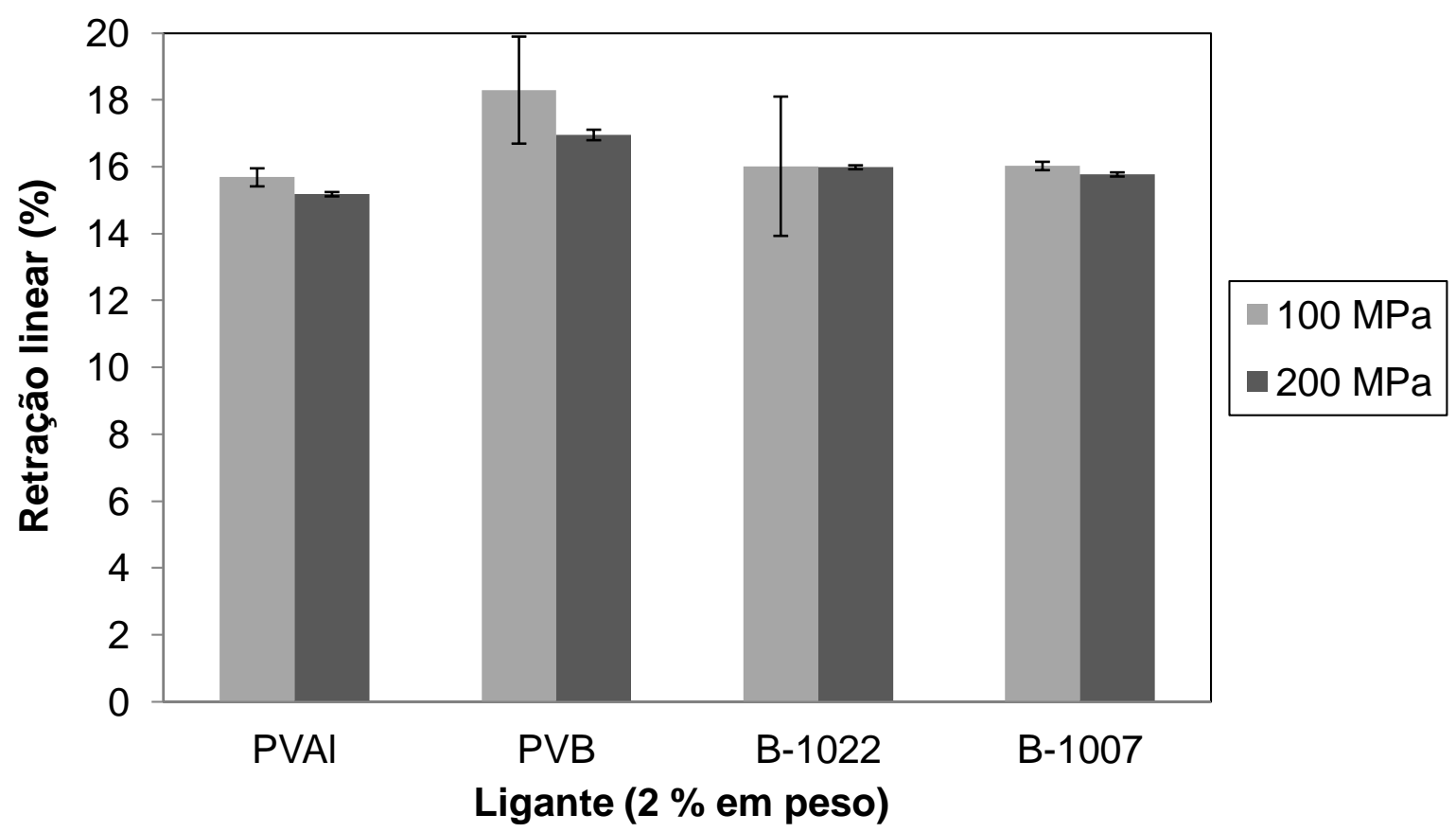

Figura 4.8 - Retração linear obtida em função do ligante utilizado.

Os valores de torque formam obtidos a partir dos 5 maiores picos de torque observados durante o processo de usinagem de uma peça, pois seriam esses os responsáveis por alguma introdução de defeito na peça. Tendo em vista que o tarugo bruto possuía um diâmetro de aproximadamente $11 \mathrm{~mm}$ e o corpo-de-prova usinado possui um diâmetro de aproximadamente $7 \mathrm{~mm}$, além disso, a profundidade de corte aplicada de $1 \mathrm{~mm}$. Foram necessários 2 passes do rebolo para obter 0 corpo de prova, sendo os maiores picos observados no primeiro passe da ferramenta, quando a peça atingiu um diâmetro de $9 \mathrm{~mm}$.

Para quantificar o esforço necessário para usinar os corpos-de-prova com os diferentes ligantes, os valores de torque de usinagem médios obtidos para os ligantes foram convertidos em potência de usinagem através da equação 1.

$$
\mathrm{P}_{\mathrm{u}}=\mathrm{M}_{\mathrm{t}} \cdot \mathrm{n} / 9,55
$$

onde, $P_{u}$ é a potência de usinagem em Watts $(W), M_{t}$ é o torque da usinagem e $n$ a rotação do spindle. 


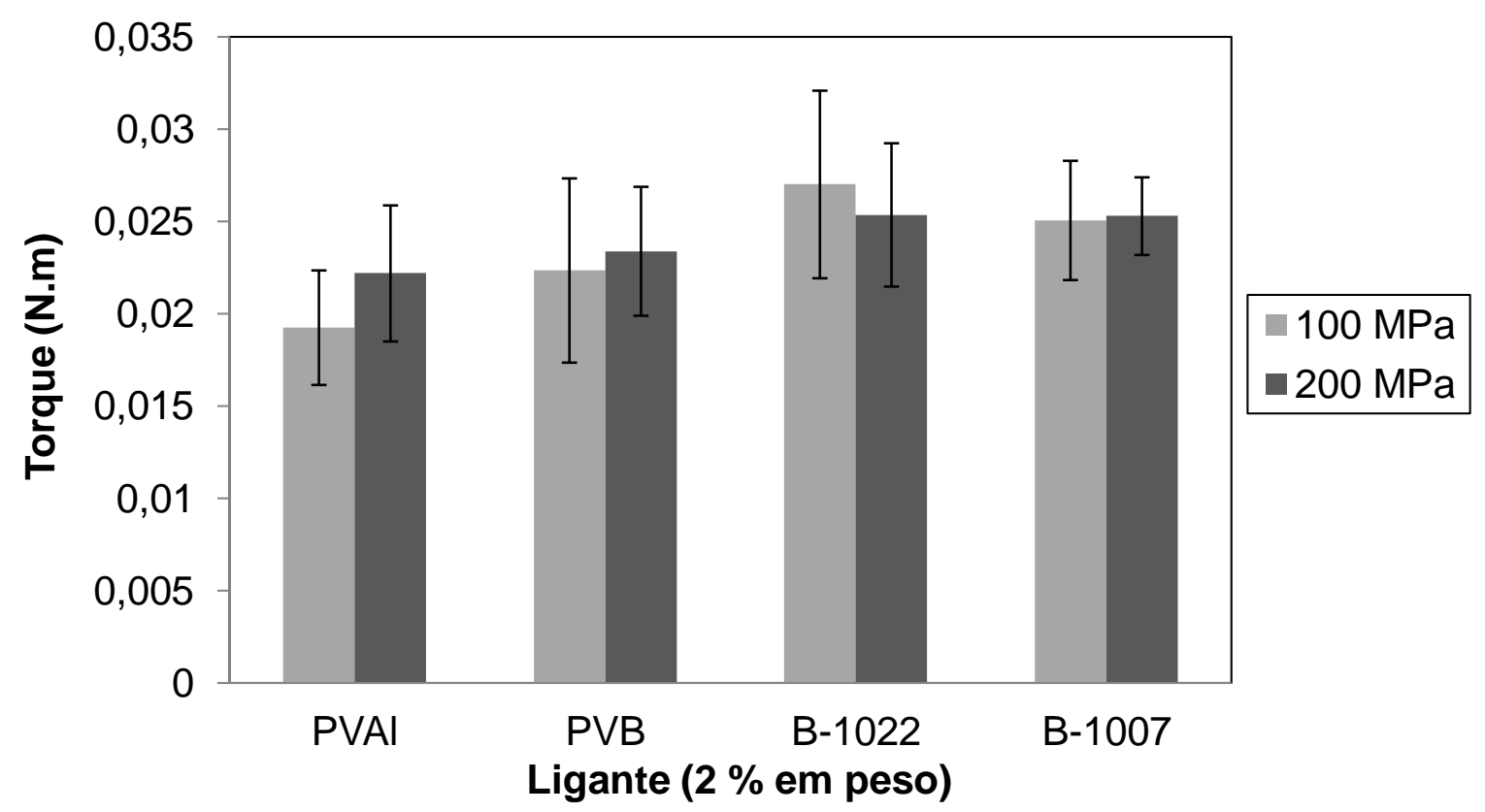

Figura 4.9 - Torque de usinagem obtido em função do ligante utilizado.

Sabendo que foram necessários dois motores para realizar a operação de retificação cilíndrica, sendo um motor por rotacionar a peça e outro para rotacionar o rebolo, então para o cálculo da potência de usinagem consumida total, foi considerada a soma das potências consumidas por cada motor.

No eixo do motor que rotacionou as peças foi acoplado o torquímetro para medição do torque durante a usinagem que gerou o gráfico da Figura 4.9. Desse foram obtidos os seguintes valores de potência para os ligantes prensados a 100 MPa: 1,696 W para o B-1022; 1,574 W para o B-1007; 1,469 W para o PVB e 1,209 W para o PVAl. Já para os ligantes prensados a $200 \mathrm{MPa}$ : 1,593 W para o B-1022; 1,588 W para o B-1007; 1,404 W para o PVB e 1,394 W para o PVAl.

Para o cálculo da potência consumida pelo spindle que rotacionou o rebolo, pode-se fazer uma relação entre o diâmetro da peça e o diâmetro do rebolo, para calcular o torque equivalente para rotacionar o rebolo. A medição do diâmetro do rebolo foi de $73,5 \mathrm{~mm}$. Levando-se em consideração que o rebolo penetra na peça com a profundidade de corte de $1 \mathrm{~mm}$, isso gera um valor médio dos diâmetros da peça e do rebolo, sendo esses $10 \mathrm{~mm}$ e $72,5 \mathrm{~mm}$ respectivamente, gerando uma relação entre diâmetros de 1:7,25. Assim, o torque necessário para rotacionar o rebolo é 7,25 vezes maior do que para rotacionar a peça, sendo então observados os valores de torque referente aos diferentes ligante nas pressões de $100 \mathrm{MPa}$ de: 0,196 N.m para o B-1022; 0,182 N.m para o B-1007; 0,162 N.m para o PVB e de 
0,140 N.m para o PVAl. Já os valores de torque para os ligante prensados a 200 MPa foram de: 0,184 N.m para o B-1022; 0,183 N.m para o B-1007; 0,169 N.m para o PVB e de 0,161 N.m para o PVAl.

Calculando as potências consumidas do spindle a $100 \mathrm{MPa}$ se tem: 236,969 W para o B-1022; 217,257 W para o B-1007; 193,382 W para o PVB e de 167,120 W para o PVAl. Já as potências consumidas do spindle referente aos diferentes ligantes prensados a $200 \mathrm{MPa}$ foram: $219,644 \mathrm{~W}$ para o B-1022; 218,450 W para o B-1007; 201,738 W para o PVB e de 192,188 W para o PVAI.

A potência total consumida, somando a do motor do corpo-de-prova e a do motor do rebolo, para a usinagem das peças em função dos ligantes prensados a $100 \mathrm{MPa}$ foram: 238,665 W para o B-1022; 218,831 W para o B-1007; 194,786 W para o PVB e de 168,329 W para o PVAl. Já para os ligantes prensados a $200 \mathrm{MPa}$ foram de: 221,237 W para o B-1022; 220,419 W para o B-1007; 203,142 W para o PVB e de 193,582 W para o PVAl. Esses valores expressam a real quantidade de energia consumida na usinagem em verde dos corpos-de-prova.

A influência do ligante na rugosidade se demonstrou oposta ao torque, sendo observados menores valores para os ligantes acrílicos, menor para o B-1007 seguido do B-1022. O maior valor de Ra foi, então, observado para o ligante PVAl e o PVB com um valor logo abaixo (Figura 4.10), demonstrando que os ligantes acrílicos oferecerem melhores acabamentos. Com a prensagem a $200 \mathrm{MPa}$ foi observada uma redução da rugosidade para todos os ligantes, sendo a maior redução para o ligante PVAl seguido do PVB, B-1022 e B-1007 com a menor redução em função da maior prensagem, porém com o melhor valor de Ra.

Relativo às perdas de propriedades mecânicas, a Figura 4.11 mostra a influência dos ligantes nas tensões de ruptura. Para a prensagem em $100 \mathrm{MPa}$, o maior valor de tensão média foi observado para o ligante acrílico B-1007; seguido do B-1022; depois pelo PVB e sendo o menor valor observado foi para o ligante PVAI. Já para a prensagem em $200 \mathrm{MPa}$ maior valor de tensão foi observado para 0 ligante PVB, seguido dos acrílico B-1007 e B-1022 e sendo o menor valor observado para o ligante PVAl.

Com a prensagem de $200 \mathrm{MPa}$, foi observada uma queda do valor da resistência mecânica para os corpos-de-prova com ligante PVAl e com os acrílicos B-1001 e B-1022, sendo observado um aumento para os corpos com o ligante PVB, 
o aumento de resistência mecânica deveria ser esperado para os demais ligantes. Diante desta divergência foi realizadas, nos corpos-de-prova, medidas de densidade aparente (pelo princípio de Arquimedes) e obtidas imagens por MEV.

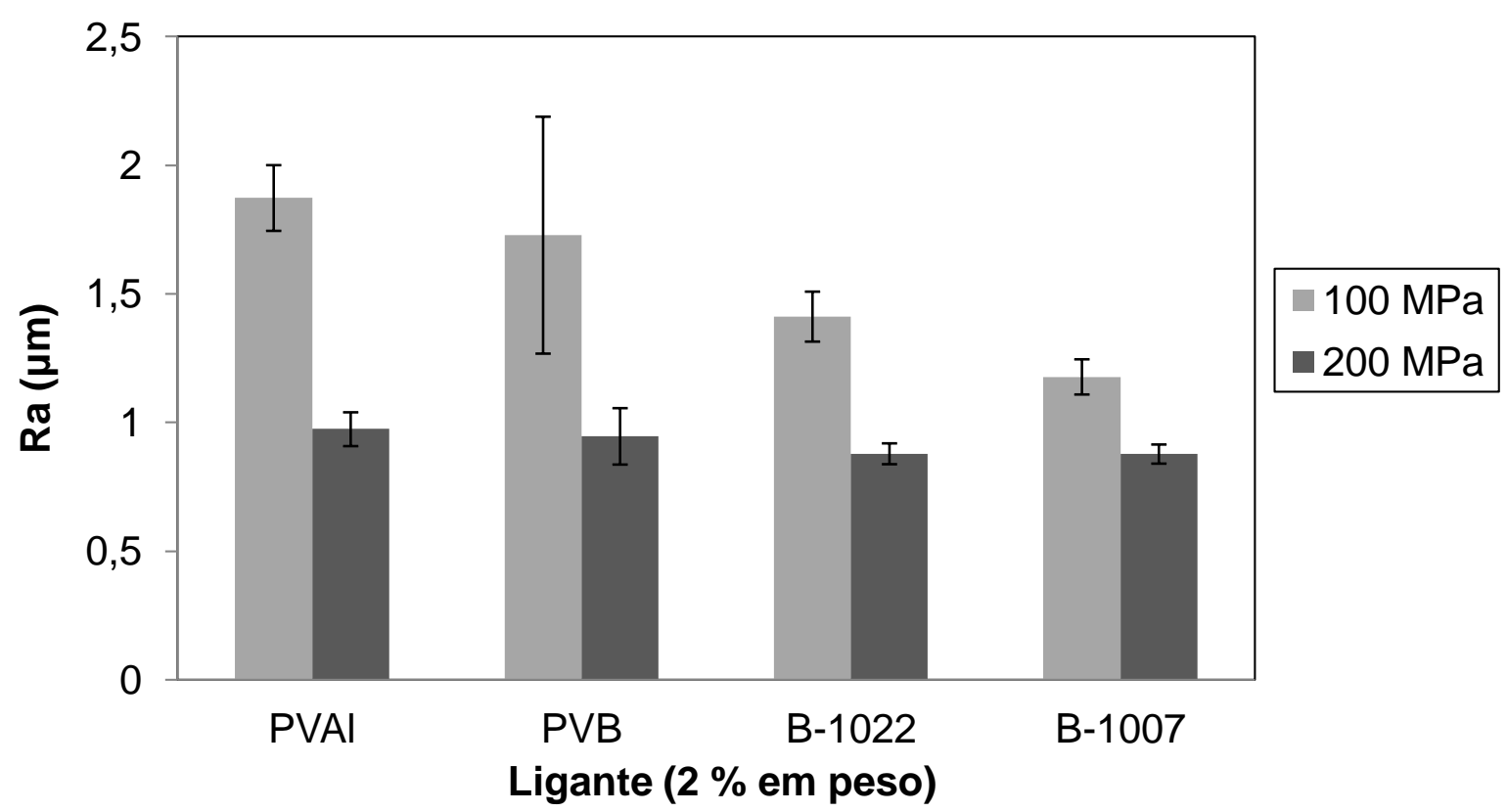

Figura 4.10 - Rugosidade média aritmética $(\mathrm{Ra})$ obtida em função dos ligantes utilizados.

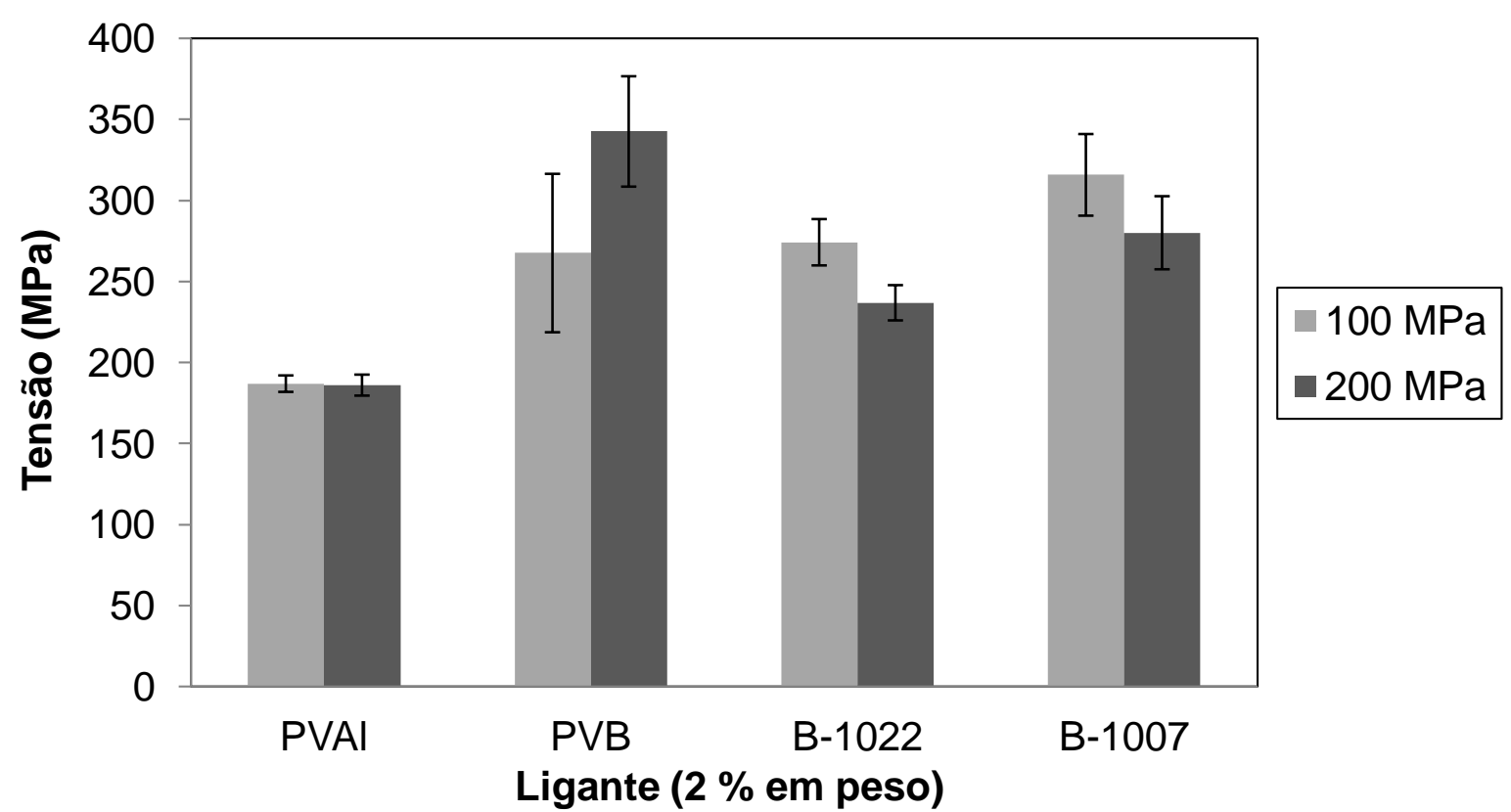

Figura 4.11 - Tensões máximas de ruptura a flexão obtidas em função do ligante utilizado. 
As medições das densidades aparentes das peças demonstraram (Figura 4.12) pequena variação devido ao aumento da pressão de compactação de 100 MPa para $200 \mathrm{MPa}$. Para os ligante acrílicos B-1007 e B-1022, foi observado um pequeno aumento da densidade, já para os ligantes PVAL e PVB, não houve uma diferença que significasse uma variação do gráfico. Mas o ligante PVAL apresentou o menor valor de densidade $\left(3,736 \mathrm{~g} / \mathrm{cm}^{3}\right)$ diante dos ligantes PVB, B-1022 e B-1007 $\left(3,903,3,882\right.$ e $3,890 \mathrm{~g} / \mathrm{cm}^{3}$ respectivamente), sendo que esses três apresentaram valores muito próximos, quando observados para a pressão de compactação de 200 MPa.

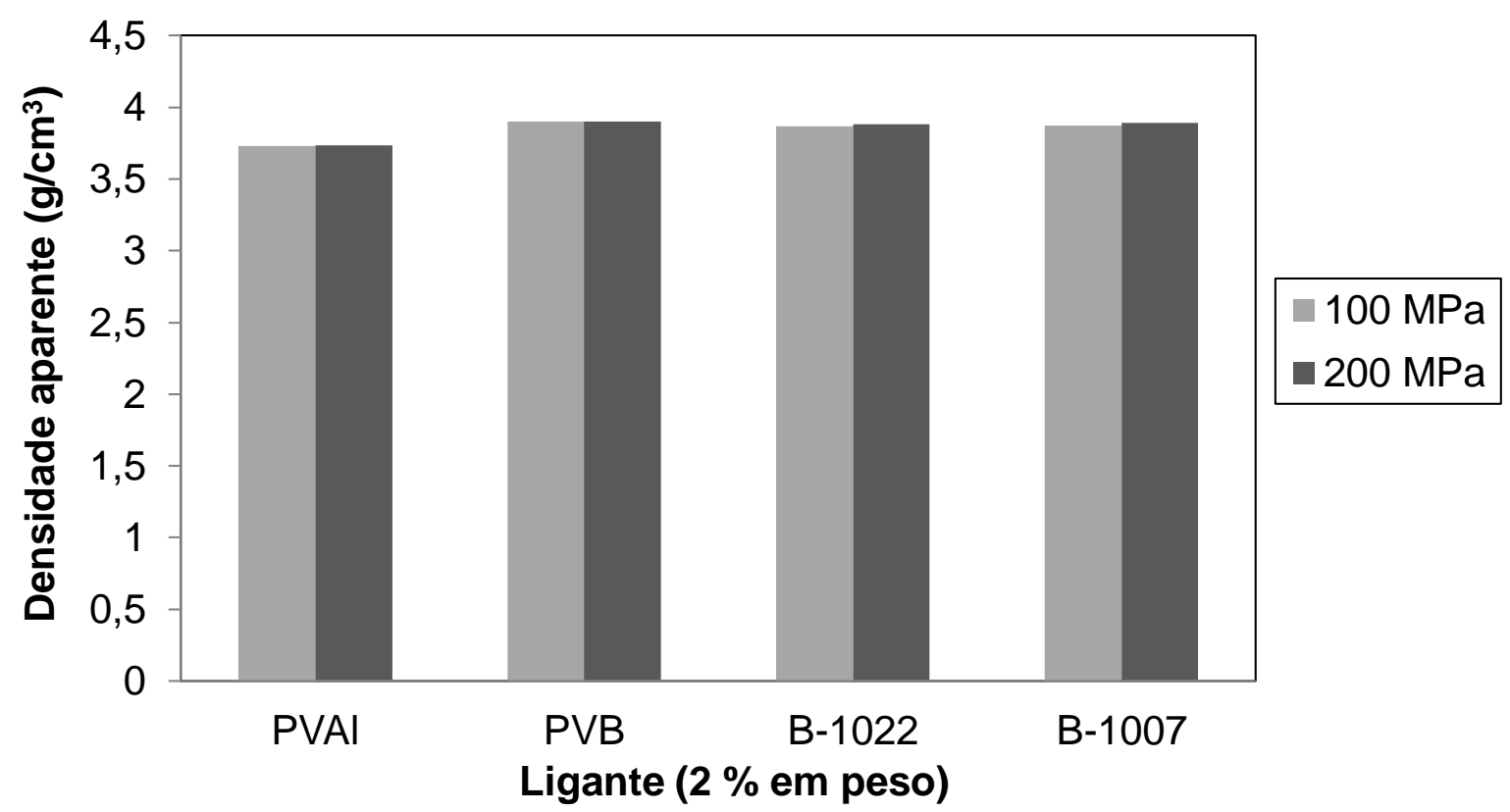

Figura 4.12 - Densidade aparente obtida em função do ligante utilizado e da pressão de compactação.

As imagens obtidas por MEV (Figura 4.13) mostraram uma pequena aumento no tamanho de grão, quando aplicada a pressão de compactação de $200 \mathrm{MPa}$ em relação a $100 \mathrm{MPa}$, para os ligantes PVAl e acrílicos B-1007 e B-1022. Já para o ligante PVB, não foi observado aumento do tamanho dos grãos, quando aplicada a pressão de $200 \mathrm{MPa}$, mas apenas um refino associado com maior densificação, que foi responsável pelo aumento da resistência mecânica para esses corpos-de-prova.

Outra característica que pode ser observada com as imagens do MEV da Figura 4.13 é em relação à porosidade. O ligante PVAl fez com que houvesse uma grande quantidade de poros no corpo-de-prova, quando comparado com os demais 
ligantes, mesmo com o aumento da pressão de compactação, que é compatível com a menor medição de densidade aparente registrada para esse ligante.
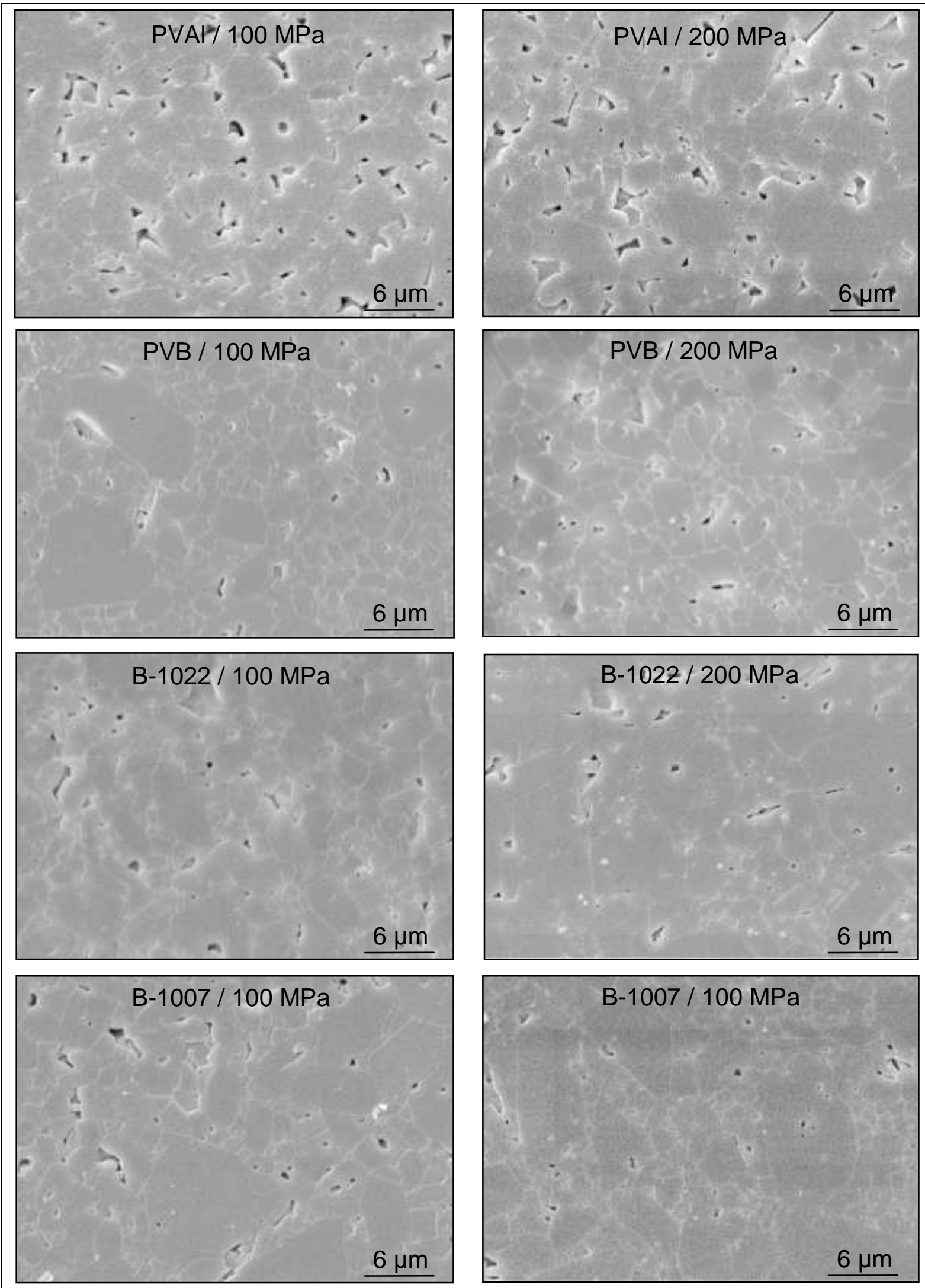

Figura 4.13 - MEV das superfícies dos corpos-de-prova com os diferentes ligantes cerâmicos. 
Os ligantes acrílicos consumiram as maiores potências de corte durante a usinagem dos corpos de prova, mas também apresentaram os maiores valores de resistência mecânica em verde, o que tornou a usinagem mais dificultada, sendo a potência de corte e a resistência mecânica a flexão em verde menores apenas para os corpos-de-prova com o ligante acrílico B-1007. Também, para estes corpos-deprova, foi encontrada uma retração linear média após a sinterização, o que significa que o ligante B-1007 auxiliou na densificação.

Já com o ligante PVAl, que forneceu a menor retração e a menor potência consumida na usinagem, obteve-se a menor resistência mecânica, a maior quantidade de lascamentos observada, a menor densidade aparente e maior quantidade de poros, o que a princípio diz que o ligante oferece menor resistência ao cisalhamento e apresentou o maior valor de Ra com a consequente perda de acabamento dos corpos-de-prova.

A composição com o ligante PVB, prensado a $200 \mathrm{MPa}$, permitiu alcançar o maior valor de resistência a ruptura, com o melhor valor de retração linear, pouco lascamento de borda, terceiro menor valor de $\mathrm{Ra}$, segundo menor torque de usinagem. Estes dados obtidos demonstram o ligante PVB como um dos melhores, dentre as opções, que pode ser utilizado na obtenção de peças cerâmicas. Porém, um grande obstáculo relacionado ao preparo do pó cerâmico com o ligante PVB e a necessidade do álcool isopropílico para sua dissolução na mistura, que neste caso poderia inviabilizar sua aplicação industrial na obtenção do pó pelo método spraydrier, o qual necessitaria de uma atmosfera controlada com gás inerte. O método convencional do spray-drier utilizada ar atmosférico a alta temperatura para a evaporação do solvente (água destilada) existente na mistura do pó cerâmico com os aditivos e o ligante. Desta forma, o ligante PVB pode entrar como uma segunda opção quando comparado com o ligante B-1007 que utiliza água como solvente.

Considerando a quantidade fixa de $2 \%$ em peso do ligante no pó e a variação da pressão de compactação, o melhor resultado médio obtido, em termos de acabamento, torque de usinagem, retração linear e resistência mecânica, foi com a adição do ligante acrílico B-1007 prensado a $200 \mathrm{MPa}$. Este ligante evitou ao máximo o lascamento de borda, permitiu a obtenção do menor Ra, permitiu um dos melhores resultados de resistência mecânica, não foi o ligante que consumiu a maior potência de torque e permitiu uma média retração linear. 


\subsubsection{Análise da variação da concentração de ligante}

Após a análise dos dados obtidos com os diferentes ligantes e sendo observado que a formulação com ligante B-1007, prensado a $200 \mathrm{MPa}$, seria a melhor opção para a obtenção de peças com as melhores características, um estudo com a variação da concentração do mesmo foi realizada.

Para este estudo foi definido as concentrações de 1, 1,5, 2 e 2,5\% em peso, sendo obtidas novas formulações de pós de alumina com cada uma dessas. Com cada formulação, foram obtidos 5 compactados brutos prensados a $200 \mathrm{MPa}$, os quais foram tratados termicamente a $100 \stackrel{\circ}{\mathrm{C}}$ por 12 horas e usinados em verde com os mesmos parâmetros de usinagem dos testes anteriores.

Após a usinagem, os corpos-de-prova foram observados em relação ao lascamento de borda (Figura 4.14), os quais demonstraram que a variação da concentração do ligante B-1007 não influenciou nos lascamentos, área circundada, mantendo-os baixo.
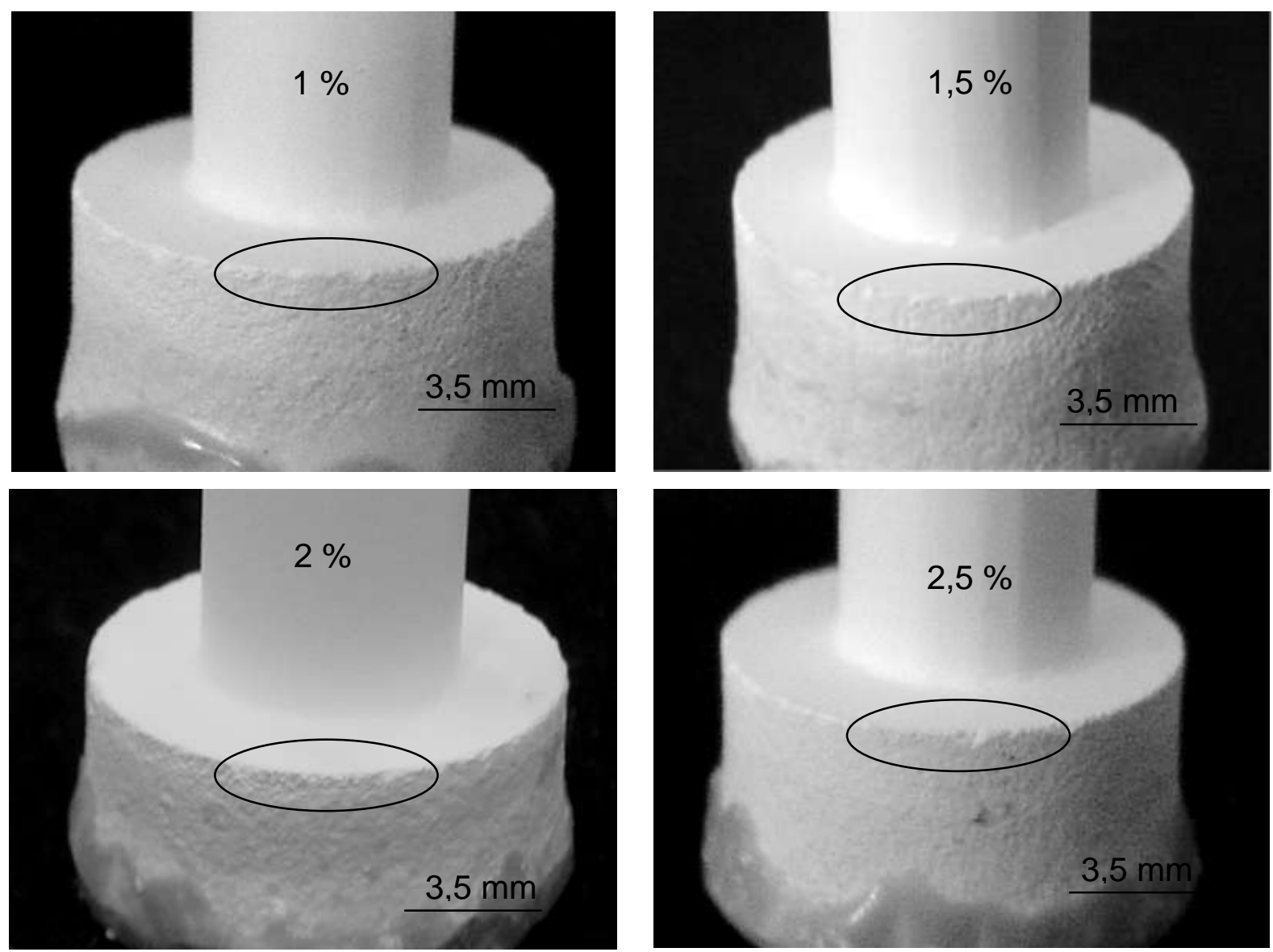

Figura 4.14 - Lascamentos de borda ocorridos durante a usinagem, em função da concentração do ligante acrílico B-1007, dos compactados prensados a $200 \mathrm{MPa}$. 
A retração linear, assim como o lascamento, não demonstrou variação significativa em relação à variação da concentração do ligante B-1007. Foi observado o valor um pouco menor para 1,5\% em peso apenas, sendo de $15,193 \%$. Já para as concentrações de 1,2 e $2,5 \%$ em peso os valores se mostraram próximos, sendo estes 15,665\%, 15,771\% e 15,761\% respectivamente (Figura 4.15).

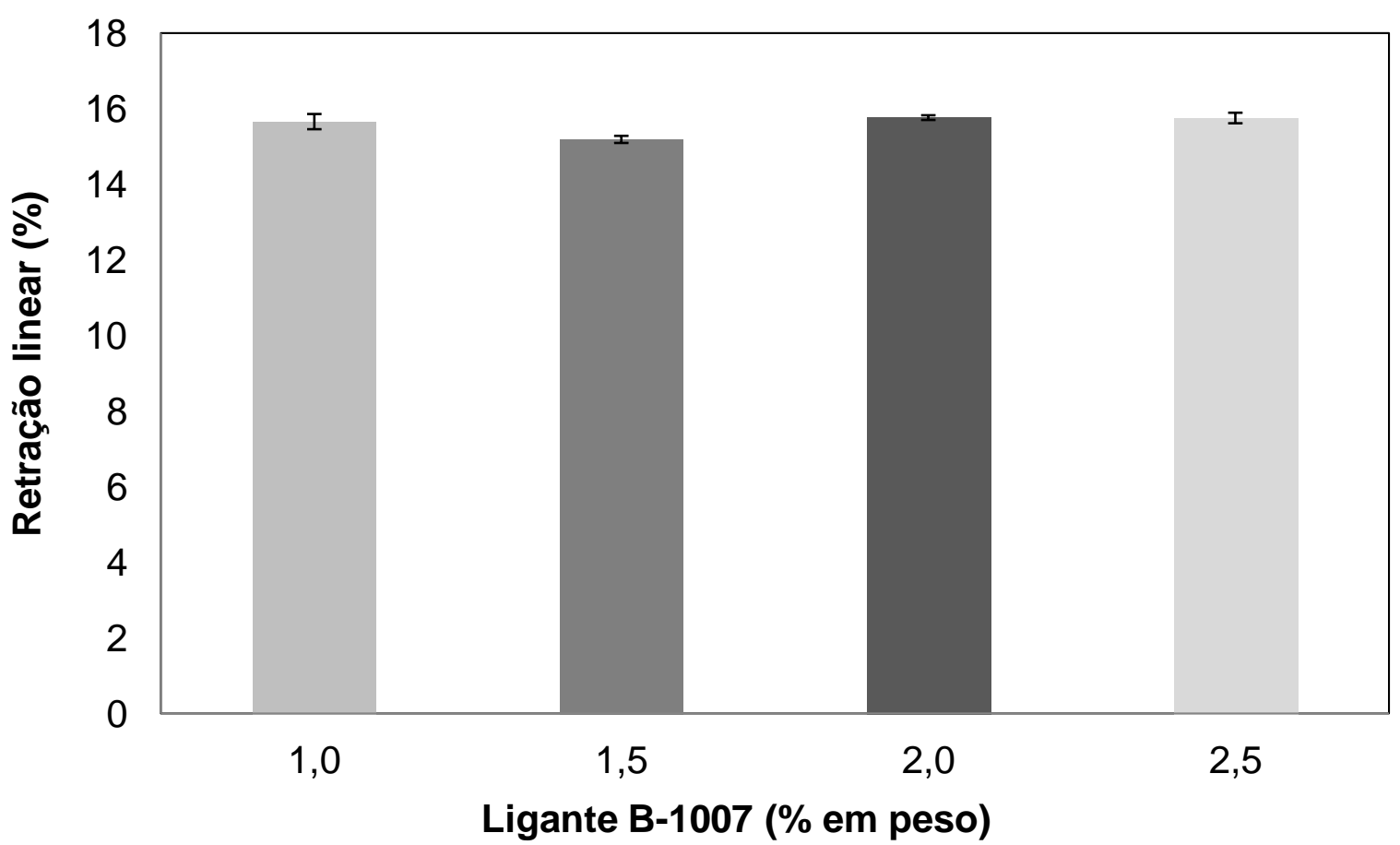

Figura 4.15 - Retração linear obtida em função da concentração do ligante acrílico B-1007.

O torque de usinagem se mostrou crescente com o aumento da concentração do ligante, como observado na Figura 4.16. Porém, para a concentração de $2 \%$ em peso houve uma pequena redução do torque em relação a adição de $1,5 \%$ em peso, valores respectivos de 0,0253 N.m e 0,0264 N.m. Foi, então, observado o menor valor para a concentração de $1 \%$ em peso e o maior valor para a concentração de 2,5\% em peso, valores respectivos de 0,0208 N.m e 0,0370 N.m. As potências totais consumidas para as concentrações de 1, 1,5, 2 e 2,5\% em peso foram 181,423 W, $230,198 \mathrm{~W}, 220,419 \mathrm{~W}$ e $322,268 \mathrm{~W}$ respectivamente.

A tensão máxima de ruptura sofreu influência da concentração do ligante (Figura 4.17), tendo sido observado um aumento da resistência mecânica com o 
aumento da concentração. Valores maiores e semelhantes de resistência foram observados para as concentrações de 2 e 2,5\% em peso, valores de 280,100 MPa e 280,592 MPa respectivamente, o que demonstra a tendência da estabilização da resistência à ruptura caso fosse feita uma mistura com uma maior adição de ligante. Porém, valores menores e semelhantes de resistência foram observados para as concentrações de 1 e 1,5\% em peso, valores de 227,823 MPa e 224,282 $\mathrm{MPa}$ respectivamente, sendo alcançado um valor um pouco menor com $1,5 \%$ em peso.

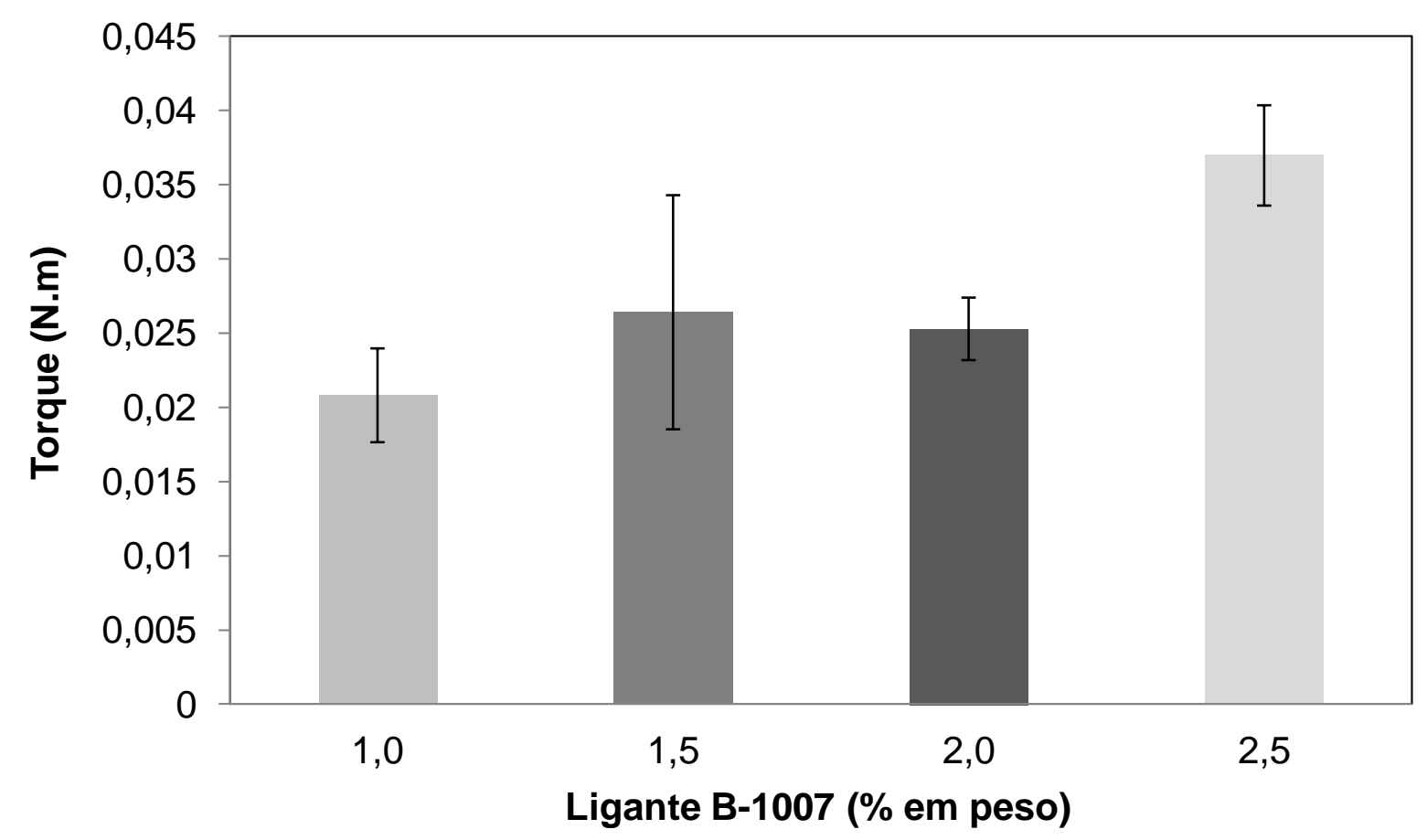

Figura 4.16 - Torque de usinagem obtido em função da concentração do ligante acrílico B-1007.

A rugosidade se mostrou decrescente com o aumento da concentração de ligante, porém, um Ra um pouco menor, valor de 0,761 $\mu \mathrm{m}$, foi observado para a concentração de 2 \% em peso (Figura 4.18). Para as concentrações de 1, 1,5 e 2,5 $\%$ em peso foram obtidos os valores de 0,886 $\mu \mathrm{m}, 0,799 \mu \mathrm{m}$ e 0,770 $\mu \mathrm{m}$, respectivamente. $\mathrm{O}$ valor do Ra para a concentração de $2 \%$ em peso difere da medição anterior devido ao uso de um rugosimetro diferente. Foi utilizado um rugosimetro sem contato da marca Veeco®, modelo $\mathrm{Wyko}^{\circledR} \mathrm{NT} 1100$, com Ra calculado sem a utilização de filtro e com comprimento de dados de 0,607 mm. $O$ valor menor de Ra obtido com este aparelho pode ser atribuído a uma melhor resolução de leitura ante ao aparelho portátil de medição por contato. 


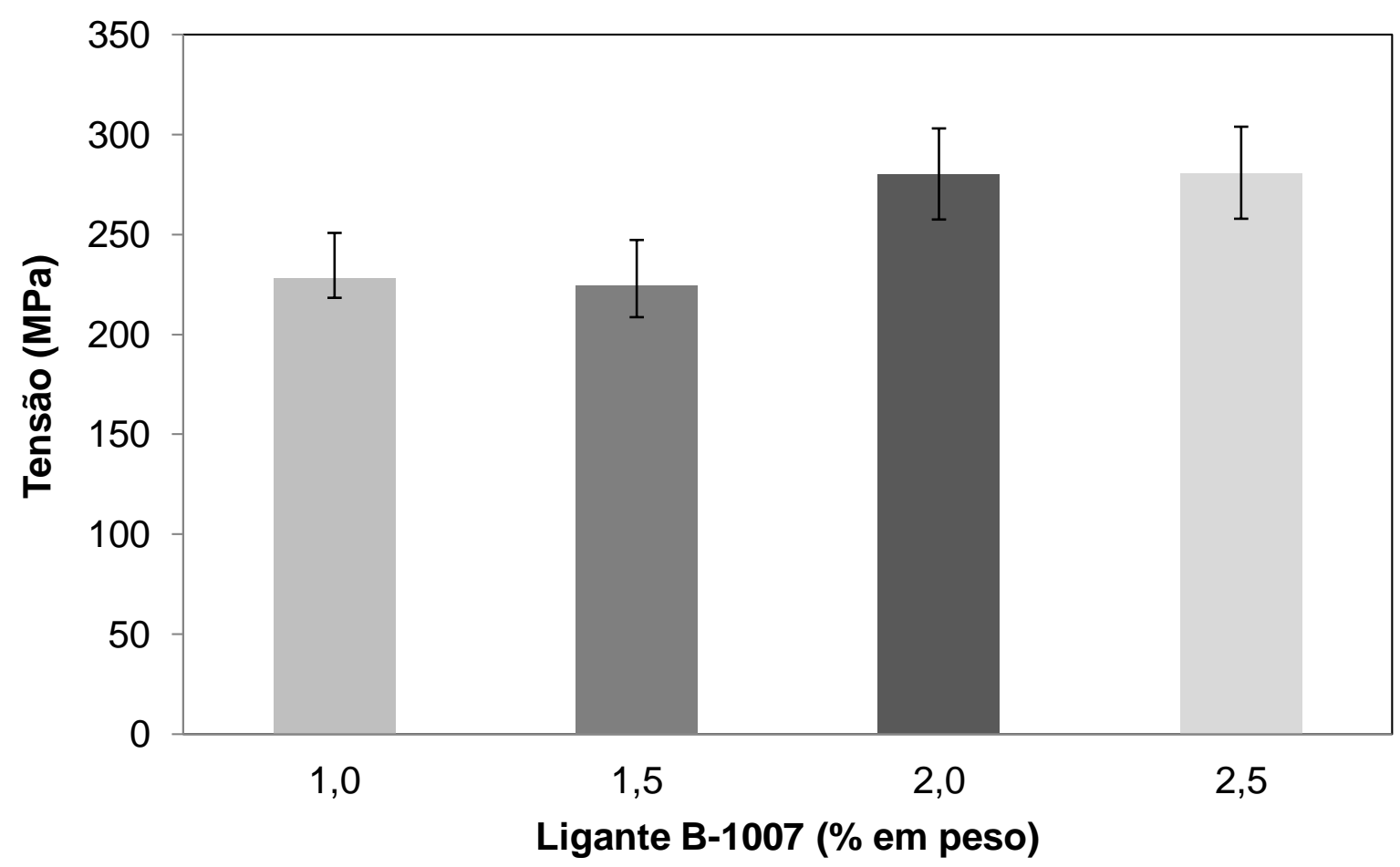

Figura 4.17 - Tensões máximas de ruptura a flexão obtidas em função da concentração do ligante acrílico B-1007.

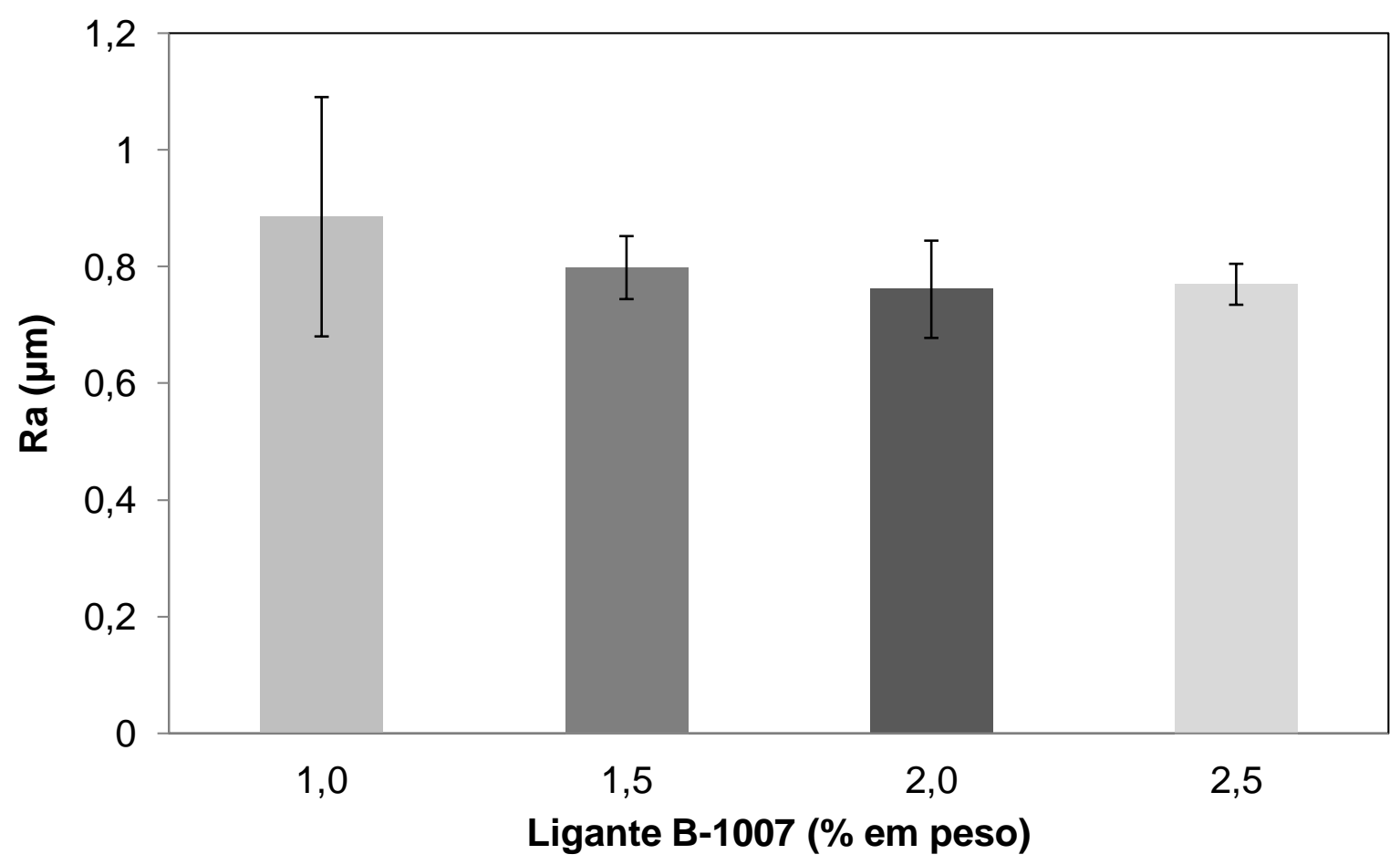

Figura 4.18 - Rugosidade média aritmética obtida em função da concentração do ligante acrílico B-1007. 
Esta análise indicou vantagem na concentração de $2 \%$ em peso do ligante B1007 na cerâmica, sendo observados os melhores valores de resistência mecânica, Ra e segundo menor torque de usinagem, que são índices que justificam a sua utilização.

\subsubsection{Resolução da estratégia de usinagem em verde na fabricação de um cilindro}

Este estudo indica vantagem no emprego de ligante acrílico B-1007 com adição de $2 \%$ em peso e pressão de compactação de $200 \mathrm{MPa}$. Usinagem aplicada com o rebolo de abrasivo de alumina e ligante vitrificado e parâmetros de usinagem com velocidade de corte de $45 \mathrm{~m} / \mathrm{s}$, profundidade de $1,0 \mathrm{~mm}$ e avanço de 400,0 $\mathrm{mm} / \mathrm{min}$, sendo observado valor de $280,1 \mathrm{MPa}$ de tensão de ruptura com rugosidade de $0,761 \mu \mathrm{m}$, consumindo potência de 220,419 W.

Dessa forma pode ser resolvida a matriz de decisão para estratégia de usinagem em verde para a fabricação de cilindros, como é observado na Figura 4.19 . 


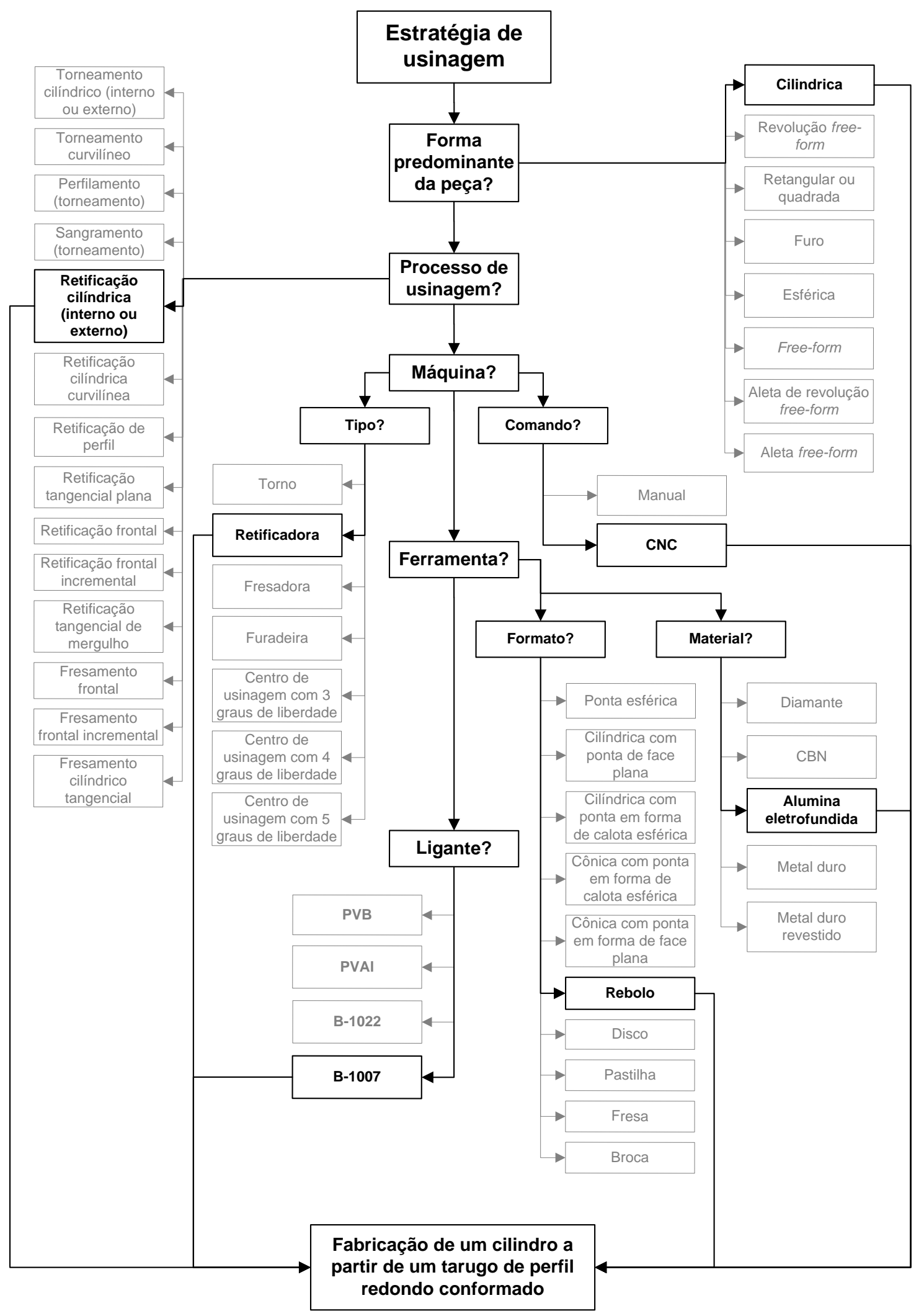

Figura 4.19 - Matriz de decisão para estratégia de usinagem em verde na fabricação de um cilindro a partir de um tarugo de perfil redondo conformado. 


\subsubsection{Resultados da estratégia de usinagem em verde na fabricação de uma superfície funcional plana}

Os resultados foram divididos em dois grupos principais, relativos ao desempenho do corte e ao acabamento que consideraram a força de corte, o material e o tamanho de grão da ferramenta e o empastamento.

\subsubsection{Análise do material e ligante da ferramenta aplicado a diferentes ligantes cerâmicos}

As medições de força de corte indicaram maiores valores de força para os ligantes acrílicos, sendo maior para o ligante B-1007 seguido pelo B-1022, posteriormente pelo ligante PVAL e por último o ligante PVB com os menores valores, como pode ser observado pelas barras maiores e menores do gráfico da Figura 4.20. De uma forma geral, as ferramentas com ligante resinoide (res) causaram as maiores forças de corte, sendo os menores valores, então, observados para as ferramentas de ligante metálico. Já as ferramentas com abrasivo de diamante ( $D$ 181), em relação às ferramentas com abrasivo de CBN (CBN 181), causaram, de uma forma geral, as menores forças de corte. Desta forma, foi observada vantagem na aplicação da ferramenta com abrasivo de diamante e ligante metálico (D 181) em relação às demais, sendo obtidos os valores de força de corte de 0,222 N para o ligante PVB; 0,503 N para o ligante PVAl; 0,604 N para o ligante B-1007 e 0,701 N para o ligante B-1022.

A análise do empastamento demonstrou, de uma forma geral, maiores valores de massa (maior empastamento) para os ligantes acrílicos, sendo observados os maiores valores para o ligante B-1022 seguido do ligante B-1007, posteriormente pelo ligante $\mathrm{PVB}$ e os menores valores observados para o ligante $\mathrm{PVAl}$, como pode ser observado pelas barras maiores e menores do gráfico da Figura 4.21. As ferramentas, em função de seus abrasivos e ligantes, não demonstraram uma tendência bem definida de suas variações de massa em função dos ligantes cerâmicos. Mas, pode ser observada vantagem da utilização da ferramenta com abrasivo de diamante com ligante metálico (D 181), sobre a ferramenta com abrasivo de CBN e ligante metálico (CBN 181), que apenas ficou em desvantagem quando comparado com o ligante PVAl. Os valores de massa obtidos para esta 
ferramenta foram de 0,008 g para o ligante PVB; 0,001 g para o ligante PVAl; 0,002 g para o ligante B-1007 e 0,003 g para o ligante B-1022.

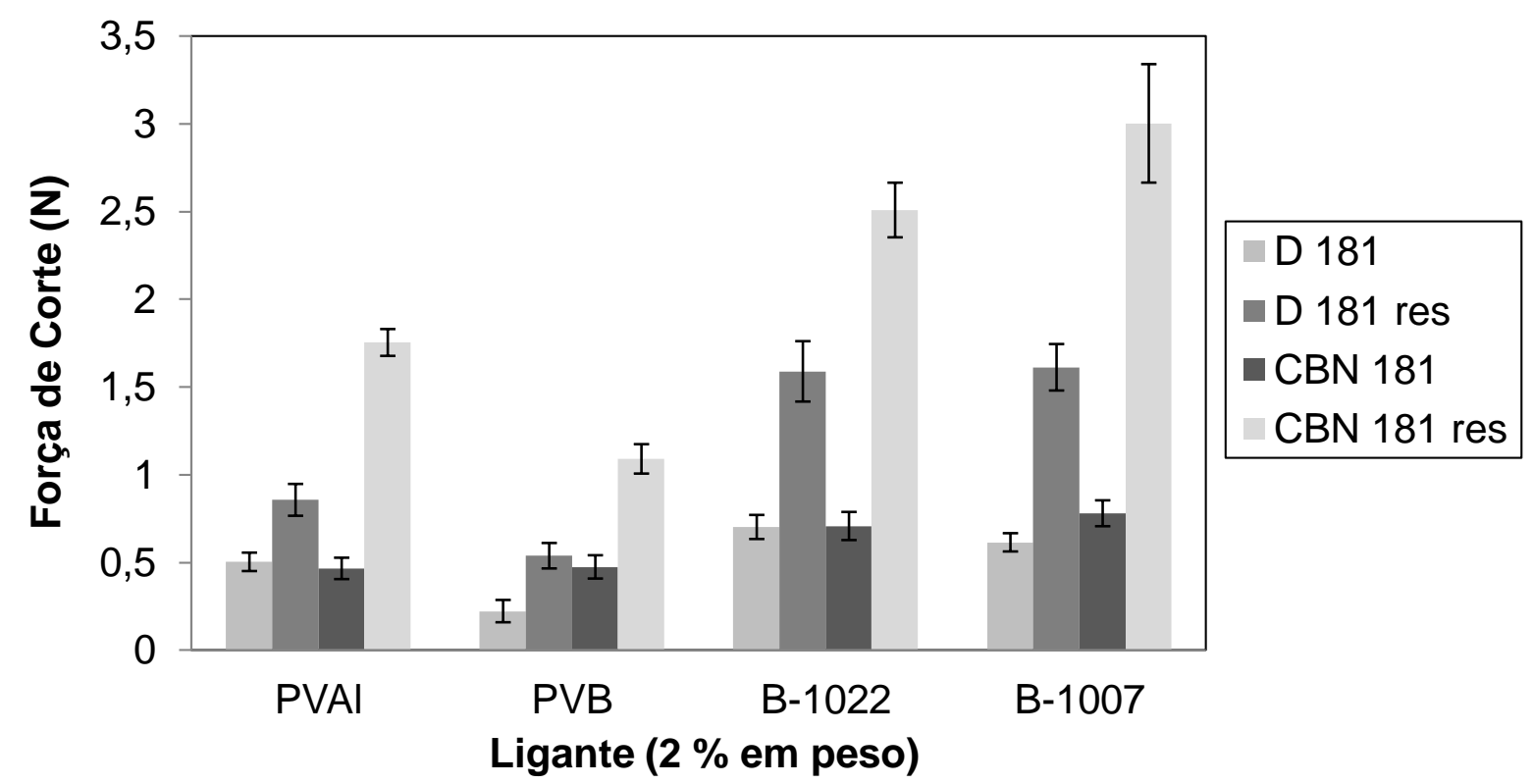

Figura 4.20 - Variação do material e ligante da ferramenta em função da força de corte.

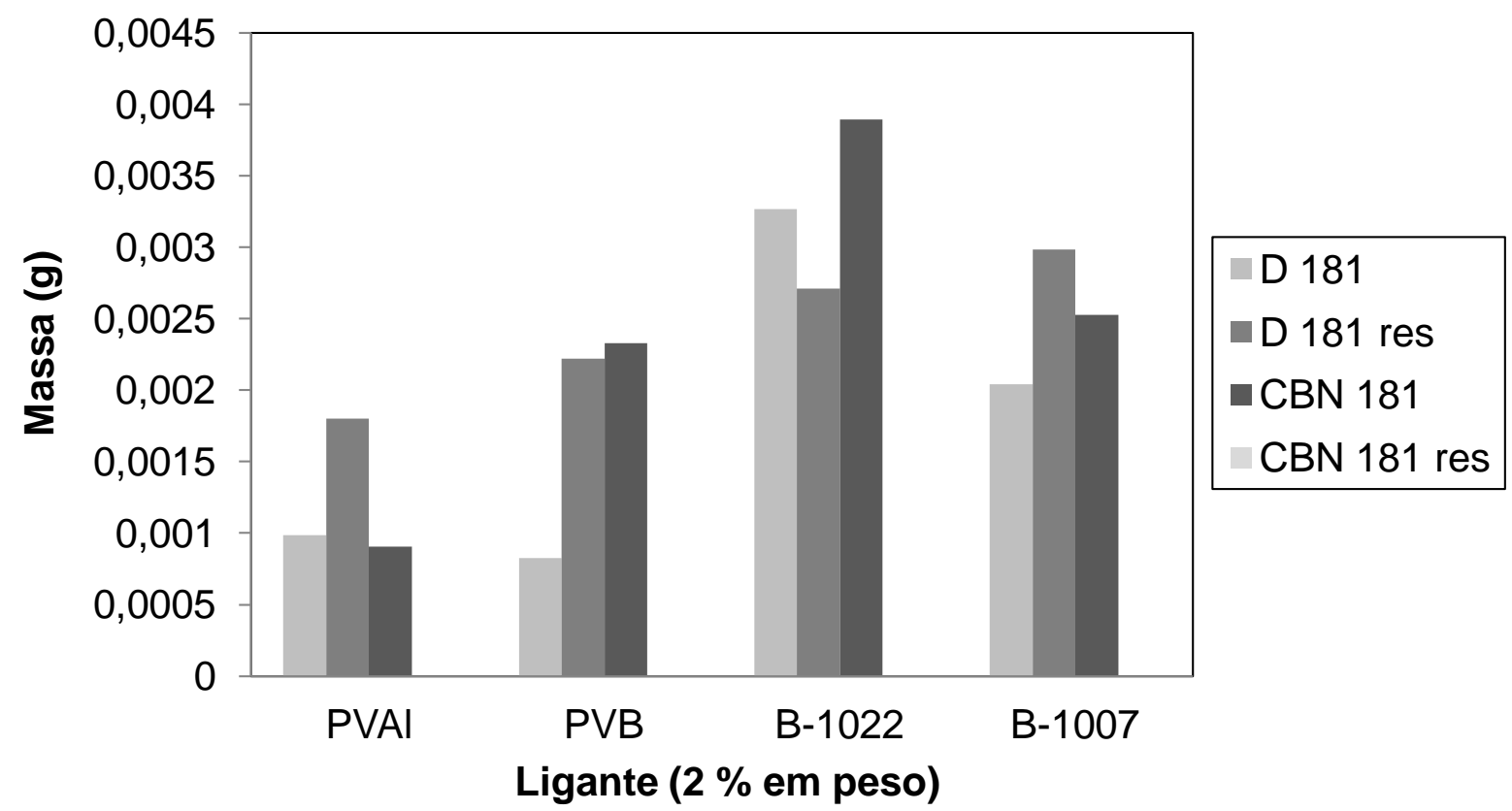

Figura 4.21 - Variação do material e ligante da ferramenta em função do valor da massa de material aderida. 
As medições de massa, com a ferramenta de abrasivo de CBN com ligante resinoide (CBN 181 res) (Figura 4.21), foram comprometidas devido à força de corte, durante a usinagem, ter causado a quebra da mesma para todos os ligantes. Isto demonstra uma desvantagem das ferramentas fabricadas com ligante resinoide, pois, apesar das ferramentas com abrasivo de diamante e ligante resinoide (D 181 res) terem suportado aos testes das usinagens com os diferentes ligantes, as mesmas poderiam quebrar também, caso fossem utilizadas mais algumas vezes.

A análise das medições de rugosidade, Figura 4.22, demonstra uma tendência de menores valores de Ra para o ligante resinoide do que para o ligante metálico na maioria das medições. Há, também, uma tendência de menores valores de rugosidade para o abrasivo de diamante na maioria das medições. Apesar das ferramentas com ligante resinoide terem apresentado os melhores resultados de rugosidade, essas apresentaram as piores respostas nas medições de força de corte e empastamento e que, neste caso, levam a desvantagem de suas aplicações.

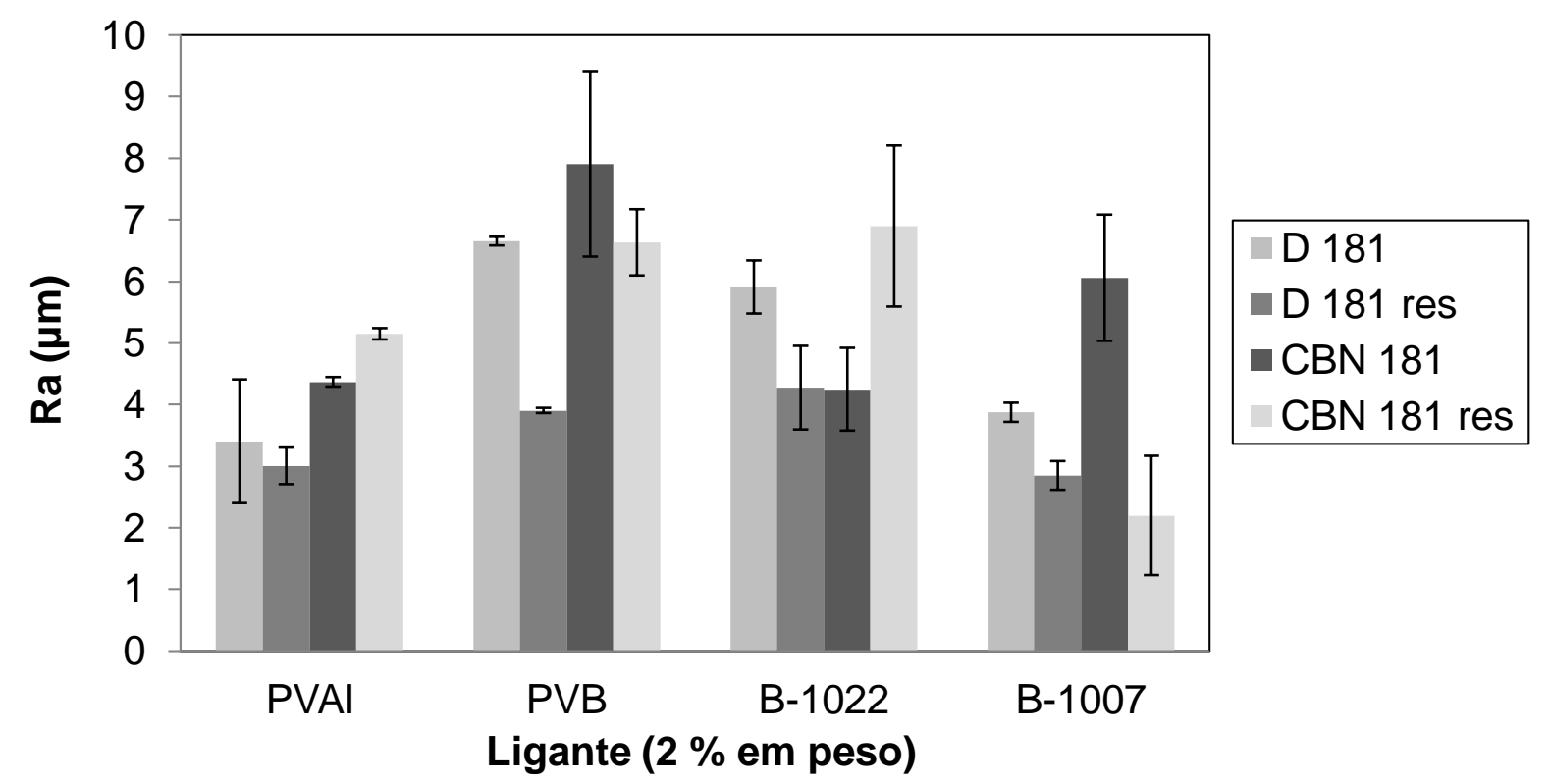

Figura 4.22 - Rugosidade média aritmética $(\mathrm{Ra})$ para a variação do material e ligante da ferramenta em função do ligante cerâmico.

O ligante acrílico B-1007 e o ligante PVAl demonstraram medições semelhantes, assim como, o ligante acrílico B-1022 e o ligante PVB, também, demonstraram medições semelhantes, porém maiores que os dois primeiros (Figura 4.22). Menores valores de Ra foram observados, para a maioria das medições, quando utilizada a ferramenta de diamante com ligante metálico (D 181) em 
comparação com a ferramenta de CBN com ligante metálico (CBN 181). Desta forma, obtidos os valores de 3,40 $\mu \mathrm{m}$ para o ligante PVAl; $3,87 \mu \mathrm{m}$ para o ligante B1007; 5,90 $\mu \mathrm{m}$ para o ligante B-1022 e 6,65 $\mu \mathrm{m}$ para o ligante PVB.

Imagens das superfícies dos corpos-de-prova usinados com a ferramenta de diamante com ligante metálico (D 181) (Figura 4.23), demonstraram um menor lascamento de borda (parte superior das imagens) para os ligantes acrílicos B-1022 e B-1007, principalmente para o ligante B-1022 o qual praticamente não demonstrou lascamentos. Já os ligantes PVAl e PVB demonstraram grande quantidade de lascamentos (parte superior das imagens). No caso do ligante PVAl, que apresentou o menor Ra nas medições de rugosidade, esta característica pode inviabilizar sua aplicação. Neste caso, vantagem fica atribuída ao ligante B-1007, que apresentou baixo lascamento de borda e o segundo menor valor de Ra.

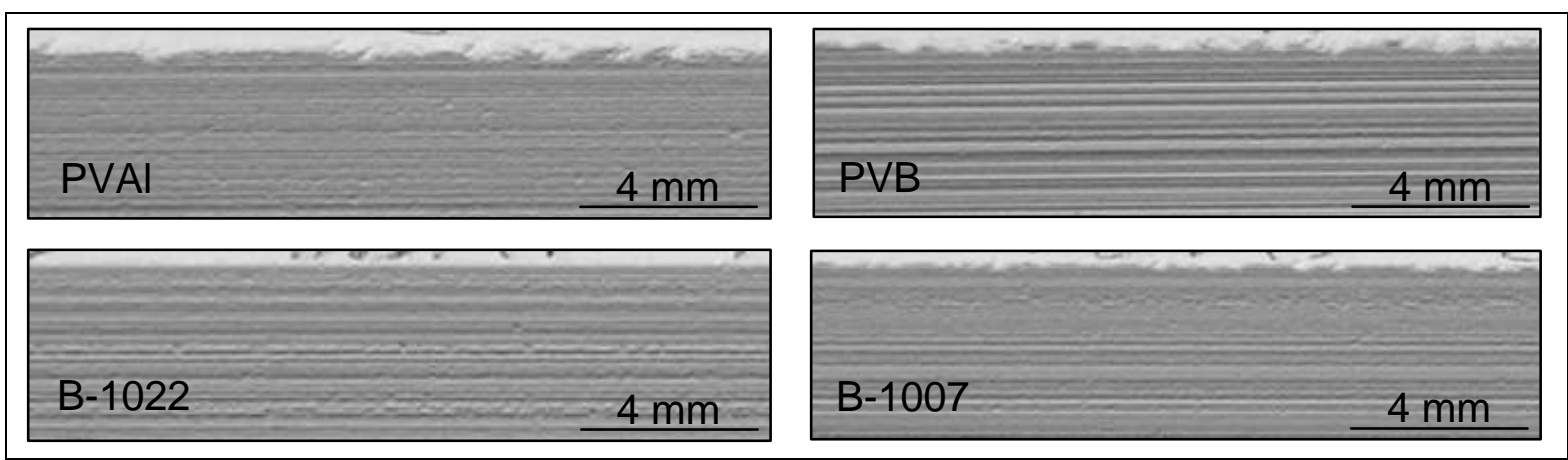

Figura 4.23 - Superfícies usinadas utilizando ferramenta de abrasivo de diamante com ligante metálico (D 181) para os diferentes ligantes cerâmicos.

As análises iniciais deste estudo indicaram vantagem na utilização de ferramentas com abrasivo de diamante e ligante metálico (D 181). Para essa ferramenta foram obtidos os menores valores de força de corte $(0,222 \mathrm{~N})$, empastamento $(0,0008 \mathrm{~g})$ e rugosidade $(3,40 \mu \mathrm{m})$.

Em relação aos ligantes cerâmicos, vantagem foi atribuída ao ligante acrílico B-1007. Esse apresentou baixo lascamento de borda, segunda menor rugosidade $(3,87 \mu \mathrm{m})$, terceiro menor empastamento $(0,002 \mathrm{~g})$ e terceira menor força de corte $(0,604 \mathrm{~N})$ quando utilizada a ferramentas com abrasivo de diamante e ligante metálico ( $D$ 181). Podem-se aliar a ele os resultados obtidos anteriormente neste trabalho, onde este ligante obteve 0 melhor resultado de rugosidade $(0,761 \mu \mathrm{m})$, segunda maior resistência mecânica $(280,1 \mathrm{MPa})$ e o menor lascamento de borda. 
Neste caso, se justifica a continuidade deste estudo, com o ligante acrílico B1007 e a ferramenta com abrasivo de diamante com ligante metálico (D 181), no estudo dos parâmetros de usinagem.

\subsubsection{Análise da velocidade de corte}

Uma análise da variação da velocidade de corte $\left(\mathrm{v}_{\mathrm{c}}\right)$ foi realizada com 0 objetivo de avaliar sua influência na força de corte e na rugosidade e determinar qual seria a melhor a ser aplicada na usinagem de um bloco de alumina com adição de 2 $\%$ em peso de ligante acrílico B-1007 compactado a $200 \mathrm{MPa}$.

Uma vez que o spindle possui uma rotação fixa $(36.500 \mathrm{rpm})$ a variação da $\mathrm{v}_{\mathrm{c}}$ foi alcançada com a mudança do diâmetro da ferramenta. Esta análise seguiu o planejamento descrito na Tabela 4.1.

Tabela 4.1 - Planejamento experimental para análise da velocidade de corte.

\begin{tabular}{|c|c|c|c|c|}
\hline Ensaio & Formulação & $\begin{array}{l}\text { Velocidade de } \\
\text { corte (vc) } \\
(\mathbf{m} / \mathbf{s})\end{array}$ & $\begin{array}{l}\text { Profundidade } \\
\text { de corte }\left(a_{\mathrm{p}}\right) \\
(\mathrm{mm})\end{array}$ & $\begin{array}{c}\text { Velocidade de } \\
\text { avanço (f) } \\
(\mathrm{mm} / \mathrm{min})\end{array}$ \\
\hline DD2-1-100 & \multirow{3}{*}{ D } & 3,82 & \multirow{3}{*}{1} & \multirow{3}{*}{100} \\
\hline DD3-1-100 & & 5,73 & & \\
\hline DD4-1-100 & & 7,64 & & \\
\hline
\end{tabular}

As dimensões das ferramentas escolhidas para esta análise foram de $2 \times 6$ $\mathrm{mm}, 3 \times 6 \mathrm{~mm}$ e $4 \times 6 \mathrm{~mm}$ (diâmetro/comprimento) com abrasivo de diamante de granulometria \#80 mesh e ligante metálico, as quais geraram velocidade de corte $\left(\mathrm{v}_{\mathrm{c}}\right)$ de $3,82 \mathrm{~m} / \mathrm{s}, 5,73 \mathrm{~m} / \mathrm{s}$ e $7,64 \mathrm{~m} / \mathrm{s}$. A descrição das ferramentas de diamante gerada pelo fabricante foi D PMD 020 D 181, D PMD 030 D 181 e D PMD 040 D 181, todas fabricadas pela empresa Master Diamond Ferramentas Ltda.

Após a usinagem com as três ferramentas foi possível observar que 0 aumento da $v_{c}$ causou uma diminuição da força de corte (Figura 4.24), sendo observados os valores de $0,980 \mathrm{~N}$ para $\mathrm{v}_{\mathrm{c}}$ de $3,82 \mathrm{~m} / \mathrm{s} ; 0,625 \mathrm{~N}$ para $\mathrm{v}_{\mathrm{c}}$ de $5,73 \mathrm{~m} / \mathrm{s}$ e $0,614 \mathrm{~N}$ para $\mathrm{v}_{\mathrm{c}}$ de $7,64 \mathrm{~m} / \mathrm{s}$.

Resposta semelhante foi observada com a rugosidade. Foi possível observar que o aumento da $v_{c}$ causou uma diminuição da rugosidade (Figura 4.25), sendo 
observados os valores de Ra de $12,45 \mu \mathrm{m}$ para $\mathrm{v}_{\mathrm{c}}$ de $3,82 \mathrm{~m} / \mathrm{s}, 7,44 \mu \mathrm{m}$ para $\mathrm{v}_{\mathrm{c}}$ de $5,73 \mathrm{~m} / \mathrm{s}$ e $3,87 \mu \mathrm{m}$ para $\mathrm{v}_{\mathrm{c}}$ de $7,64 \mathrm{~m} / \mathrm{s}$.

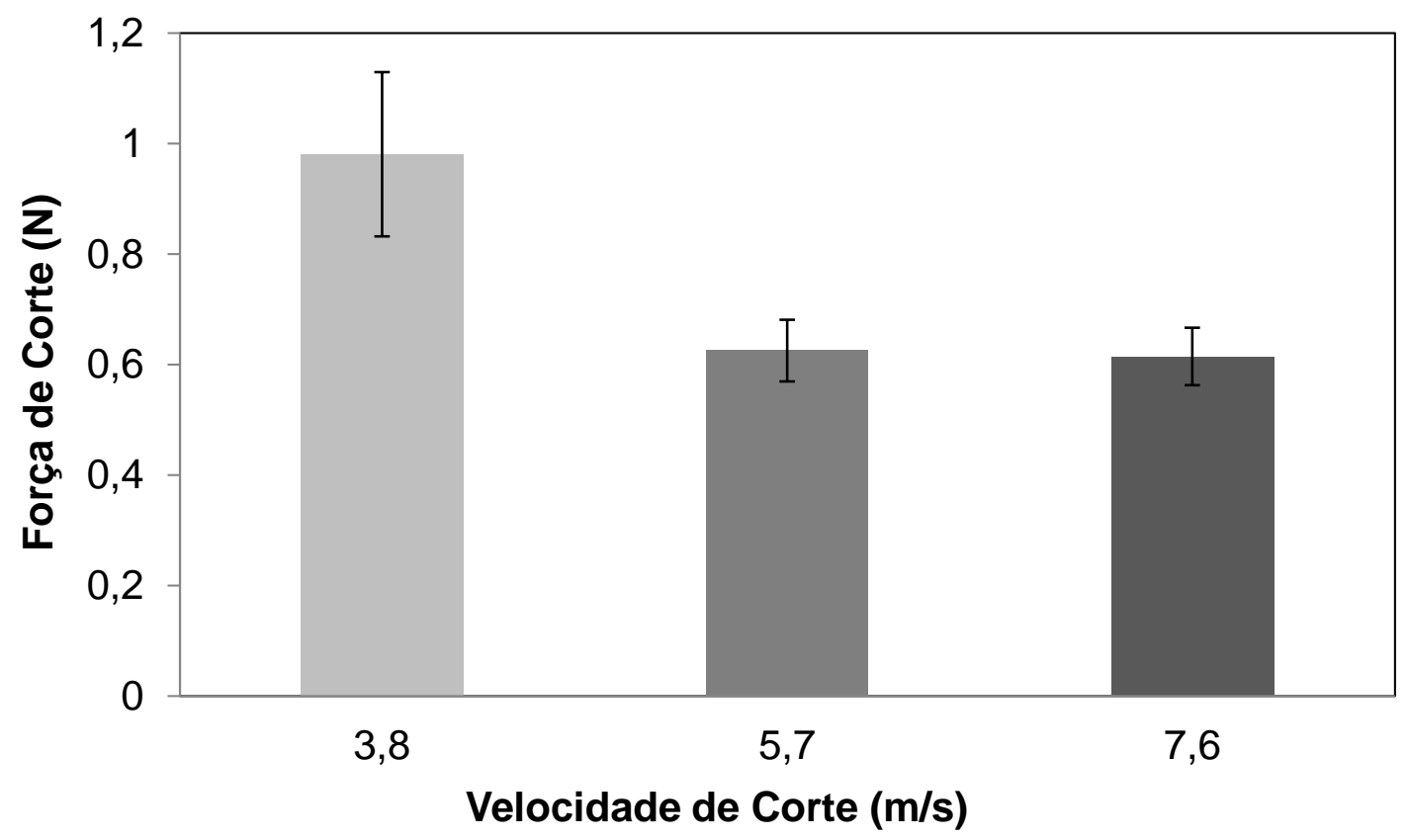

Figura 4.24 - Análise da velocidade de corte em função da força de corte.

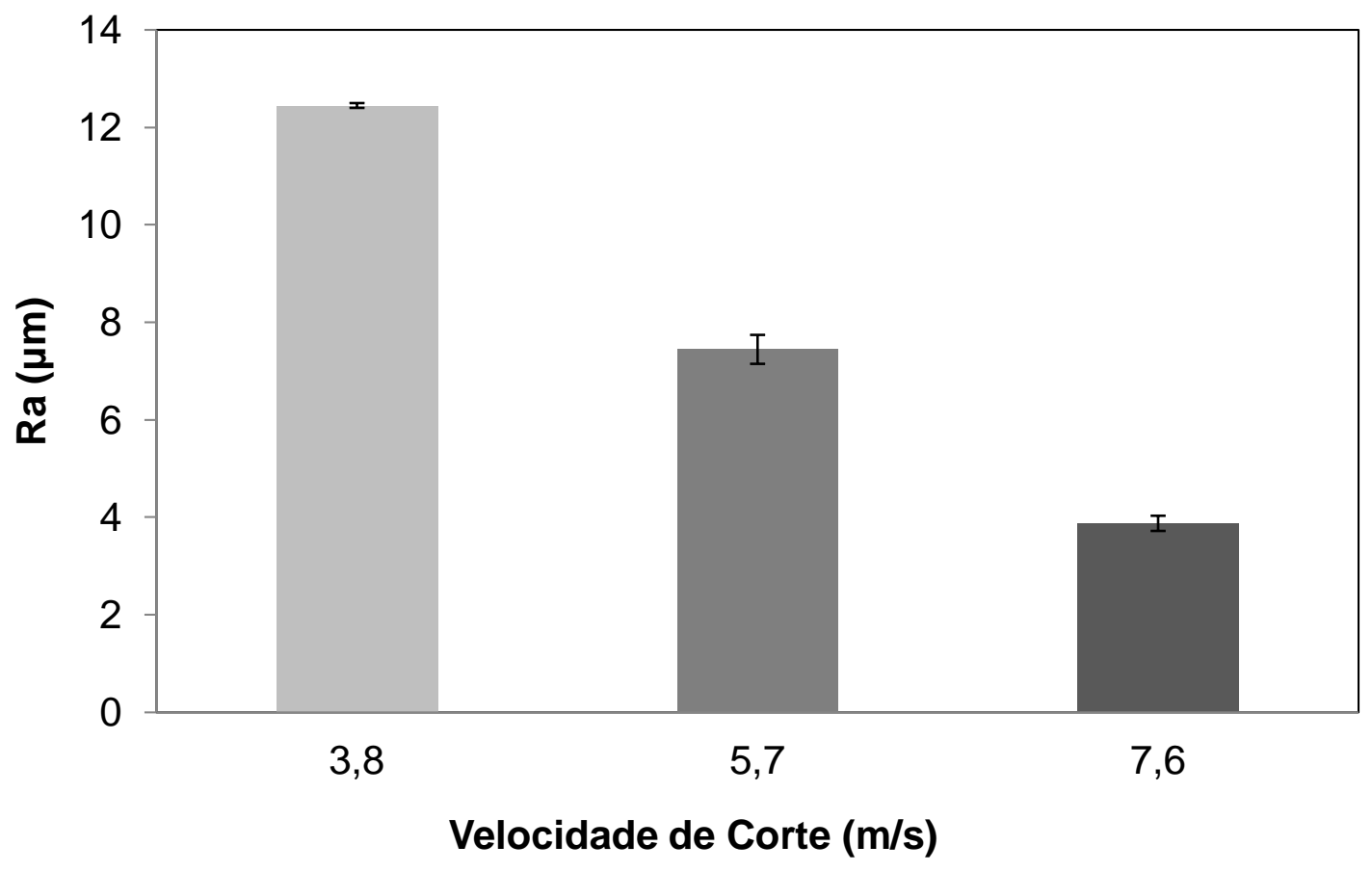

Figura 4.25 - Análise da velocidade de corte em função rugosidade média aritmética $(\mathrm{Ra})$. 
Esta análise demonstra vantagem na aplicação da maior $v_{c}$ na usinagem em verde. Com esta velocidade foi possível obter os mais baixos valores de força de corte e rugosidade que justifica sua aplicação.

\subsubsection{Análise da velocidade de avanço}

Após a análise da velocidade de corte $\left(\mathrm{v}_{\mathrm{c}}\right)$, uma análise da variação da velocidade de avanço ( $f$ ) foi realizada com o objetivo de avaliar sua influência na força de corte e na rugosidade e determinar qual seria a melhor a ser aplicada na usinagem de um bloco de alumina com adição de $2 \%$ em peso de ligante acrílico B1007 compactado a $200 \mathrm{MPa}$. Esta análise seguiu o planejamento descrito na Tabela 4.2.

Tabela 4.2 - Planejamento experimental para análise da velocidade de avanço.

\begin{tabular}{|c|c|c|c|c|}
\hline Ensaio & Formulação & $\begin{array}{l}\text { Velocidade } \\
\text { de corte (vc) } \\
(\mathrm{m} / \mathrm{s})\end{array}$ & $\begin{array}{l}\text { Profundidade de } \\
\text { corte }\left(a_{p}\right) \\
(\mathrm{mm})\end{array}$ & $\begin{array}{l}\text { Velocidade de } \\
\text { avanço (f) } \\
\text { (mm/min) }\end{array}$ \\
\hline DD4-1-50 & \multirow{5}{*}{ D } & \multirow{5}{*}{7,64} & \multirow{5}{*}{1} & 50 \\
\hline DD4-1-75 & & & & 75 \\
\hline DD4-1-100 & & & & 100 \\
\hline DD4-1-125 & & & & 125 \\
\hline DD4-1-150 & & & & 150 \\
\hline
\end{tabular}

A ferramenta utilizada para esta análise foi a de dimensão $4 \times 6 \mathrm{~mm}$ (diâmetro/comprimento) com abrasivo de diamante de granulometria \#80 mesh e ligante metálico, que gerou $\mathrm{v}_{\mathrm{c}}$ de $7,64 \mathrm{~m} / \mathrm{s}$. A descrição da ferramenta de diamante gerada pelo fabricante foi D PMD 040 D 181, fabricada pela empresa Master Diamond Ferramentas Ltda.

Após as usinagens com as diferentes $f$ foi possível observar uma tendência de aumento da força de corte com o aumento da f (Figura 4.26). Porém, uma queda da força de corte média foi observada para of de $100,0 \mathrm{~mm} / \mathrm{min}$ em relação a $f$ de $75,0 \mathrm{~mm} / \mathrm{min}$. Os valores em ordem crescente, então, obtidos foram de $0,555 \mathrm{~N}$ para f de $50,0 \mathrm{~mm} / \mathrm{min} ; 0,614 \mathrm{~N}$ para $f$ de $100,0 \mathrm{~mm} / \mathrm{min} ; 0,701 \mathrm{~N}$ para $\mathrm{f}$ de $75,0 \mathrm{~mm} / \mathrm{min}$; $0,890 \mathrm{~N}$ para $\mathrm{f}$ de $125,0 \mathrm{~mm} / \mathrm{min}$ e $0,971 \mathrm{~N}$ para $f$ de $150,0 \mathrm{~mm} / \mathrm{min}$. Apesar da $\mathrm{f}$ de 
$50,0 \mathrm{~mm} / \mathrm{min}$ gerar a menor força de corte, pode se justificar a aplicação da f de 100 $\mathrm{mm} / \mathrm{min}$, mesmo com o acréscimo da força de corte, devido a esse necessitar da metade do tempo para realizar a mesma operação de usinagem.

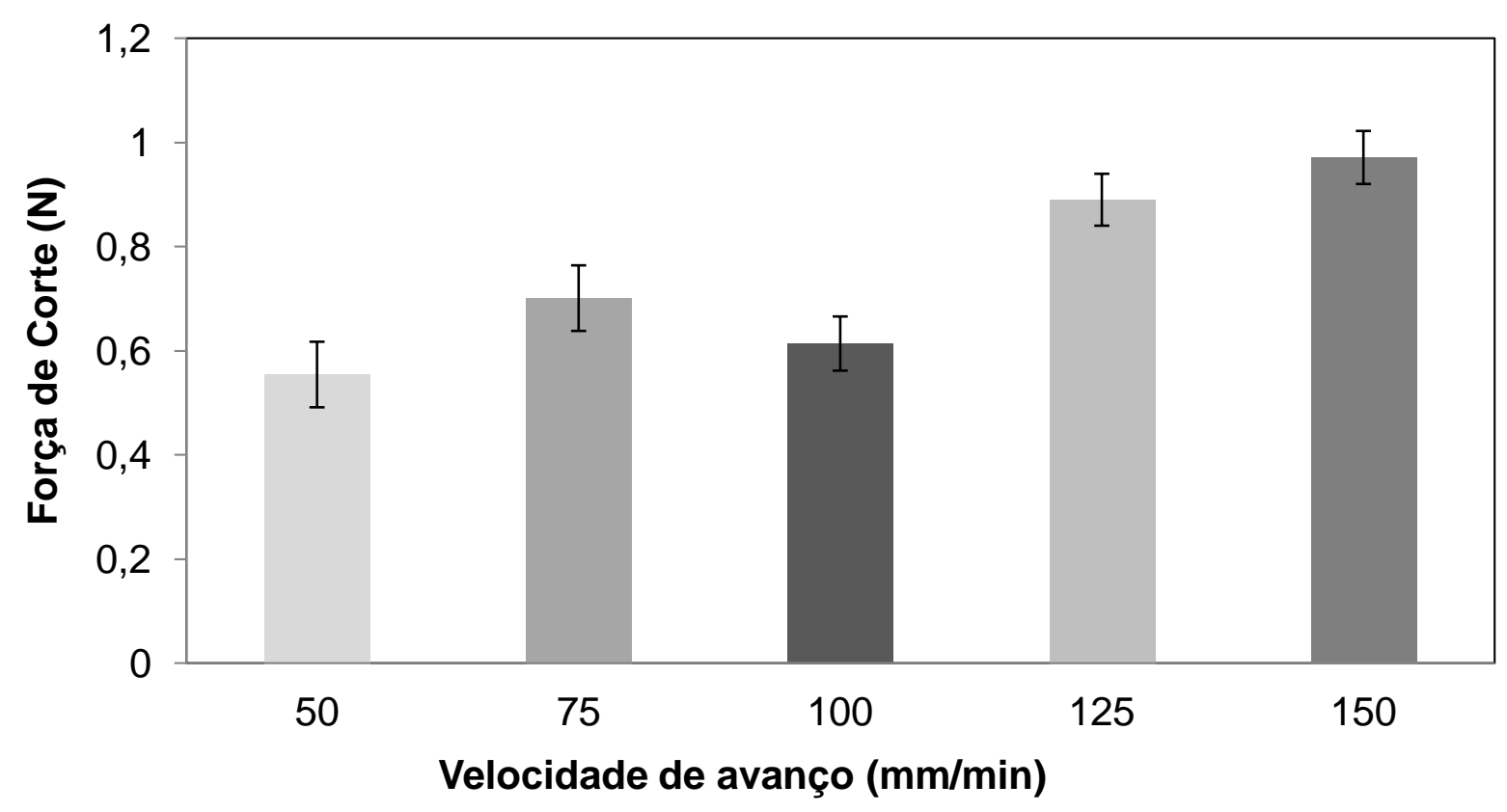

Figura 4.26 - Análise da velocidade de avanço em função da força de corte.

O aumento da f demonstrou uma tendência de queda do valor da rugosidade, porém, para $f$ de $50,0 \mathrm{~mm} / \mathrm{min}$, foi observado um valor menor do que o observado para $\mathrm{f}$ de $75,0 \mathrm{~mm} / \mathrm{min}$ (Figura 4.27). Os valores de rugosidade observados, em ordem decrescente, em função da f foi Ra de $4,53 \mu \mathrm{m}$ para $\mathrm{f}$ de $75,0 \mathrm{~mm} / \mathrm{min}, 3,87$ $\mu \mathrm{m}$ para $\mathrm{f}$ de $100,0 \mathrm{~mm} / \mathrm{min}, 3,70 \mu \mathrm{m}$ para $\mathrm{f}$ de $125,0 \mathrm{~mm} / \mathrm{min}, 3,28 \mu \mathrm{m}$ para $\mathrm{f}$ de $50,0 \mathrm{~mm} / \mathrm{min}$ e $3,08 \mu \mathrm{m}$ para $\mathrm{f}$ de $150,0 \mathrm{~mm} / \mathrm{min}$. Apesar das maiores $\mathrm{f}$ gerarem valores menores de rugosidade, a aplicação destes poderiam gerar defeitos subsuperficiais (trincas) no corpo-de-prova devido as maiores forças de corte.

Apesar da $f$ de 100,0 mm/min não gerar a menor força de corte e nem o melhor valor de rugosidade, sua aplicação se justifica com a vantagem de realizar uma mesma usinagem na metade do tempo da f de $50,0 \mathrm{~mm} / \mathrm{min}$ com o segundo menor valor de força de corte. E apesar de permitir o quarto melhor valor de Ra, terá uma menor chance de introduzir defeitos subsuperficiais com a sua menor força de corte em relação à f de 125,0 mm/min e 150,0 mm/min. 


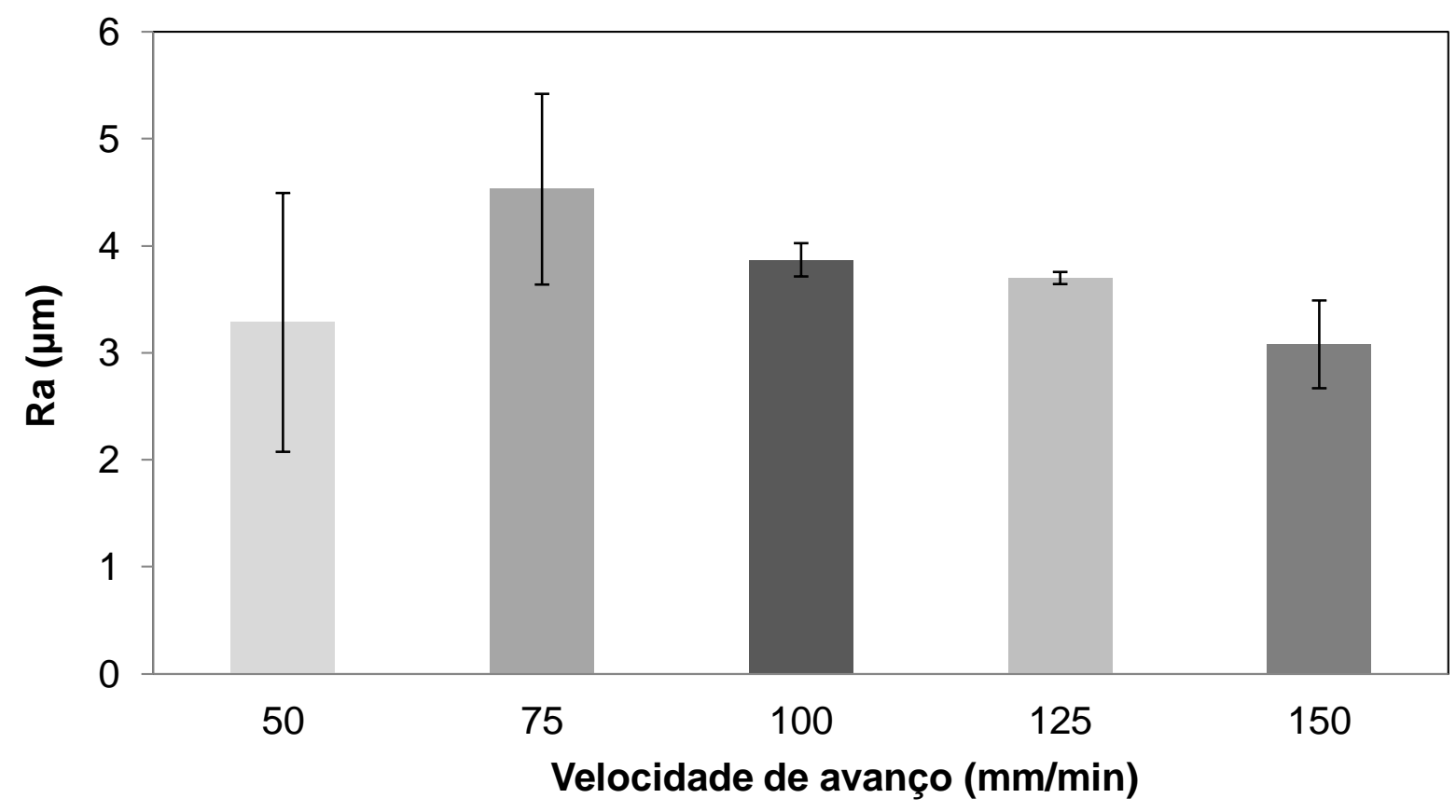

Figura 4.27 - Análise da velocidade de avanço em função rugosidade média aritmética (Ra).

\subsubsection{Análise da profundidade de corte}

Após a análise da velocidade de corte $\left(\mathrm{v}_{\mathrm{c}}\right)$ e da velocidade de avanço (f), uma análise da variação da profundidade de corte $\left(a_{p}\right)$ foi realizada com o objetivo de avaliar sua influência na força de corte e na rugosidade e determinar qual seria a melhor a ser aplicada na usinagem de um bloco de alumina com adição de $2 \% \mathrm{em}$ peso de ligante acrílico B-1007 compactado a $200 \mathrm{MPa}$. Esta análise seguiu o planejamento descrito na Tabela 4.3.

Tabela 4.3 - Planejamento experimental para análise da profundidade de corte.

\begin{tabular}{|c|c|c|c|c|}
\hline Ensaio & Formulação & $\begin{array}{l}\text { Velocidade } \\
\text { de corte }(\mathrm{vc}) \\
(\mathrm{m} / \mathrm{s})\end{array}$ & $\begin{array}{l}\text { Profundidade de } \\
\text { corte }\left(a_{\mathrm{p}}\right) \\
(\mathrm{mm})\end{array}$ & $\begin{array}{l}\text { Velocidade de } \\
\text { avanço (f) } \\
\text { (mm/min) }\end{array}$ \\
\hline DD4-0,5-100 & \multirow{5}{*}{ D } & \multirow{5}{*}{7,64} & 0,5 & \multirow{5}{*}{100} \\
\hline DD4-0,75-100 & & & 0,75 & \\
\hline DD4-1,0-100 & & & 1 & \\
\hline DD4-1,25-100 & & & 1,25 & \\
\hline DD4-1,5-100 & & & 1,5 & \\
\hline
\end{tabular}


A ferramenta utilizada para esta análise foi a de dimensão $4 \times 6 \mathrm{~mm}$ (diâmetro/comprimento) com abrasivo de diamante de granulometria \#80 mesh e ligante metálico, que gerou $\mathrm{v}_{\mathrm{c}}$ de $7,64 \mathrm{~m} / \mathrm{s}$. A descrição da ferramenta de diamante gerada pelo fabricante foi D PMD 040 D 181, fabricadas pela empresa Master Diamond Ferramentas Ltda.

Após a usinagem com as diferentes $a_{p}$, pode ser observada uma tendência de aumento da força de corte com o aumento do $a_{p}$ (Figura 4.28). Desta forma, foram alcançados os valores de força de corte, em ordem crescente, em função da ap de 0,555 $\mathrm{N}$ para ap de $0,5 \mathrm{~mm} ; 0,554 \mathrm{~N}$ para ap de $0,75 \mathrm{~mm} ; 0,614 \mathrm{~N}$ para ap de $1 \mathrm{~mm}$; $0,715 \mathrm{~N}$ para ap de $1,25 \mathrm{~mm}$ e 0,805 $\mathrm{N}$ para ap de 1,5 mm, sendo que para as $\mathrm{a}_{\mathrm{p}}$ de $0,5 \mathrm{~mm}$ e $0,75 \mathrm{~mm}$ os valores se mostram idênticos.

Um ponto importante que deve ser levado em consideração com a usinagem em verde, é em relação à quantidade de passes da ferramenta que é aplicada às peças. A quantidade de passes está diretamente ligada à espessura de material que deverá ser removida de uma peça. Neste caso, quanto maior a $a_{p}$, menor é a quantidade de passes e quanto menor a $a_{p}$, maior é a quantidade de passes. No trabalho de Bukvic (2011) pode ser observado que um aumento da $a_{p}$ evitou a deterioração da borda dos corpos-de-prova usinados em verde, defeito que pode levar ao descarte de uma peça.

Desta forma, a aplicação da $a_{p}$ de $1,0 \mathrm{~mm}$ pode ser justificada, apesar de não gerar a menor força de corte quando comparada com as ap de 0,5 mm e 0,75 mm, porém, evitando uma possível introdução de defeito na borda.

As medições de rugosidade demonstraram uma tendência de aumento com o aumento da $a_{p}$ (Figura 4.29). Porém, uma queda da rugosidade foi observada para $a a_{p}$ de $1 \mathrm{~mm}$ em relação a $a_{p}$ de $0,75 \mathrm{~mm}$. Os valores em ordem crescente, então, obtidos de Ra foram de $3,49 \mu \mathrm{m}$ para $a_{p}$ de $0,5 \mathrm{~mm} ; 3,87 \mu \mathrm{m}$ para $a_{p}$ de $1 \mathrm{~mm} ; 4,05$ $\mu \mathrm{m}$ para $a_{p}$ de $0,75 \mathrm{~mm} ; 4,43 \mu \mathrm{m}$ para $a_{p}$ de $1,5 \mathrm{~mm}$ e 4,65 $\mu \mathrm{m}$ para $a_{p}$ de $1,25 \mathrm{~mm}$.

Apesar da $a_{p}$ de 1,0 mm não gerar a menor força de corte (terceiro menor valor) e nem o melhor valor de rugosidade (segundo menor valor), sua aplicação se justifica pelo fato de necessitar de uma menor quantidade de passes da ferramenta, evitando a introdução de defeitos na borda, para atingir uma mesma remoção de material, em comparação a $a_{p}$ de $0,5 \mathrm{~mm}$ que mostrou os melhores resultados. 


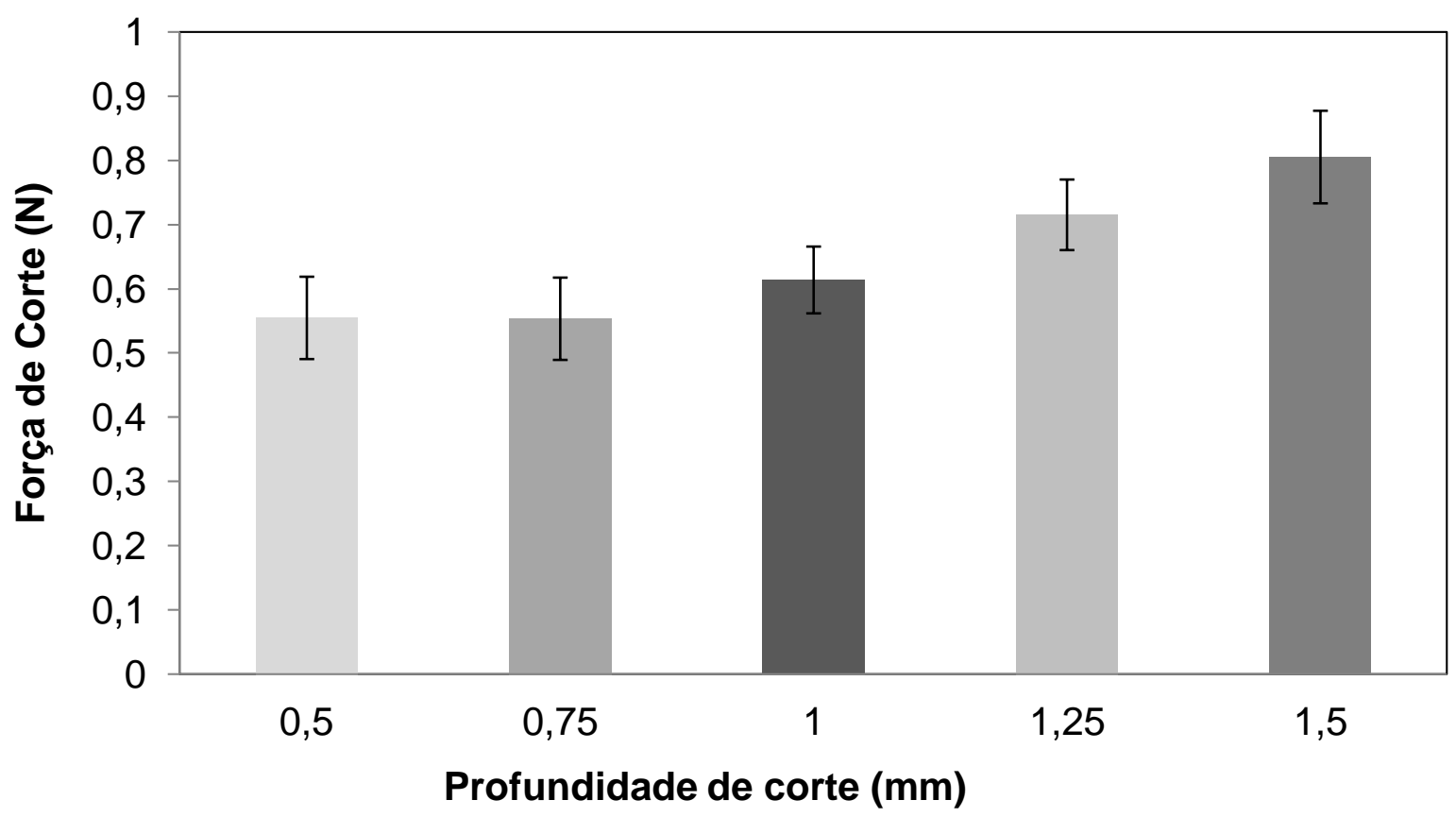

Figura 4.28 - Análise da profundidade de corte em função da força de corte.

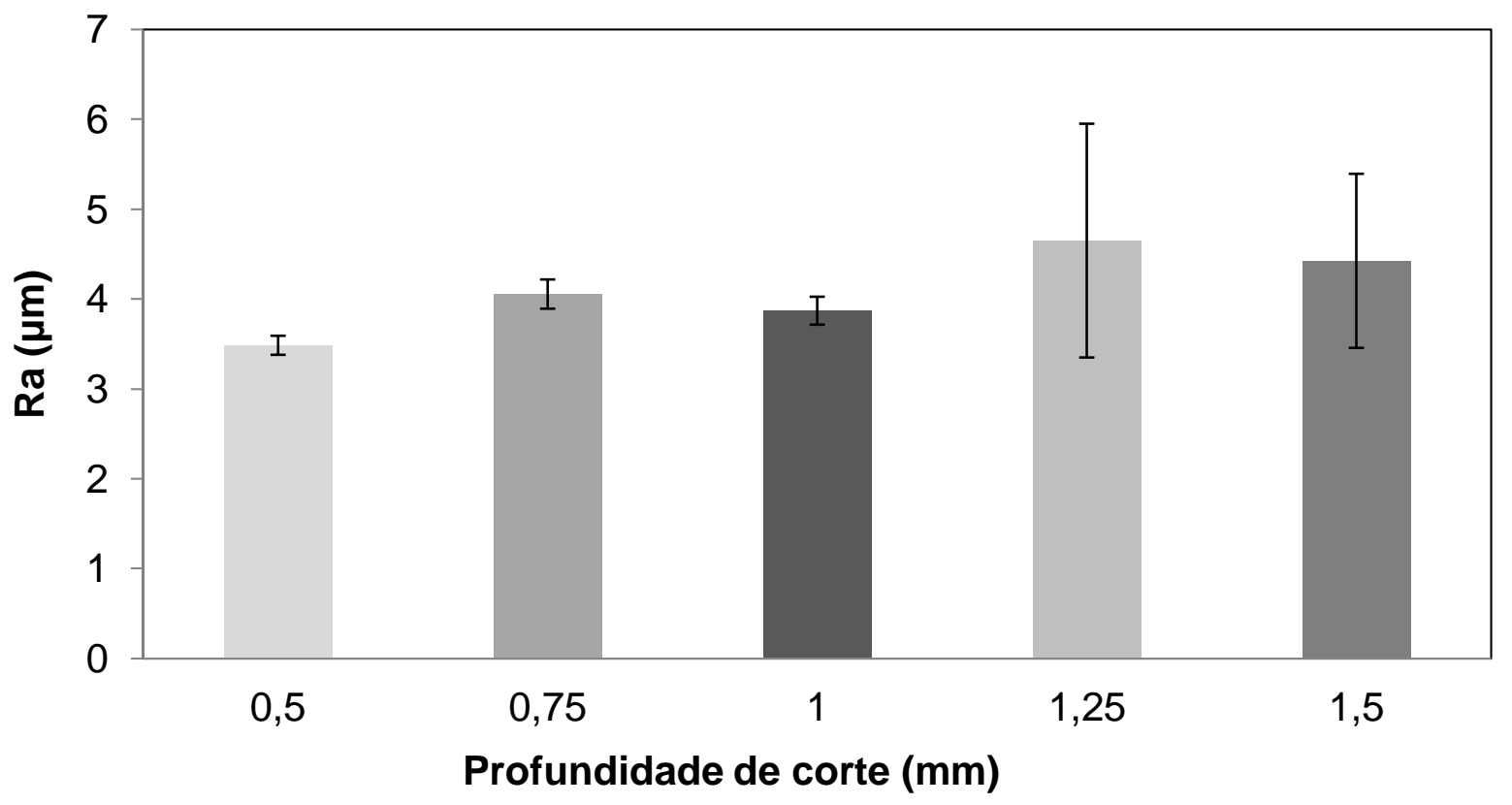

Figura 4.29 - Análise da profundidade de corte em função rugosidade média aritmética (Ra). 


\subsubsection{Análise do tamanho de grão e material da ferramenta}

As análises realizadas demonstraram vantagem na aplicação de ferramentas com abrasivo de diamante de granulometria \#80 mesh e ligante metálico, utilizando os seguintes parâmetros de usinagem: vc de $7,64 \mathrm{~m} / \mathrm{s}$, f de $100 \mathrm{~mm} / \mathrm{min}$ e ap de 1 $\mathrm{mm}$.

Como não houve variação do tamanho de grão do abrasivo, uma nova análise foi realizada com uma segunda ferramenta, também, com abrasivo de diamante, porém, de granulometria \#120 mesh e ligante metálico e de mesmas dimensões da ferramenta anterior. A descrição da ferramenta de diamante gerada pelo fabricante foi D PMD 040 D 126, fabricada pela empresa Master Diamond Ferramentas Ltda.

E com o intuito de fazer uma comparação deste estudo com o estudo da matriz de decisão para estratégia de usinagem em verde na fabricação de cilindros, foi realizada a análise da aplicação de uma terceira ferramenta com abrasivo de alumina eletrofundida de granulometria \#80 mesh e ligante vitrificado e de mesmas dimensões das ferramentas de diamante.

Após a usinagem com a aplicação das três ferramentas, utilizando os melhores parâmetros de usinagem, pode ser observado que com a aplicação de um menor tamanho de grão do abrasivo de diamante na ferramenta (D 126) foi possível obter uma força de corte menor $(0,529 \mathrm{~N})$ em comparação com a ferramenta de maior tamanho de grão do abrasivo (D 181) $(0,614 \mathrm{~N})$. Porém, a ferramenta de alumina eletro fundida com ligante vitrificado (Alum. Eletr.) demonstrou a maior força de corte $(1,054 \mathrm{~N}$ ) das três ferramentas (Figura 4.30). A princípio um menor tamanho de grão do abrasivo de diamante demonstrou vantagem sobre o maior tamanho de grão do abrasivo de diamante.

A análise do empastamento demonstrou desvantagem da ferramenta de alumina eletro fundida com ligante vitrificado (Alum. Eletr.), pois esta obteve a maior variação de sua massa em comparação com as ferramentas de diamante com ligante metálico (Figura 4.31). Desta forma, em ordem decrescente temos a Alum. Eletr. com $0,0027 \mathrm{~g}$; a D $126 \mathrm{com} 0,0022 \mathrm{~g}$ e a D $181 \mathrm{com} 0,0020 \mathrm{~g}$, o que demonstra vantagem à ferramenta de diamante com maior tamanho de grão do abrasivo. 


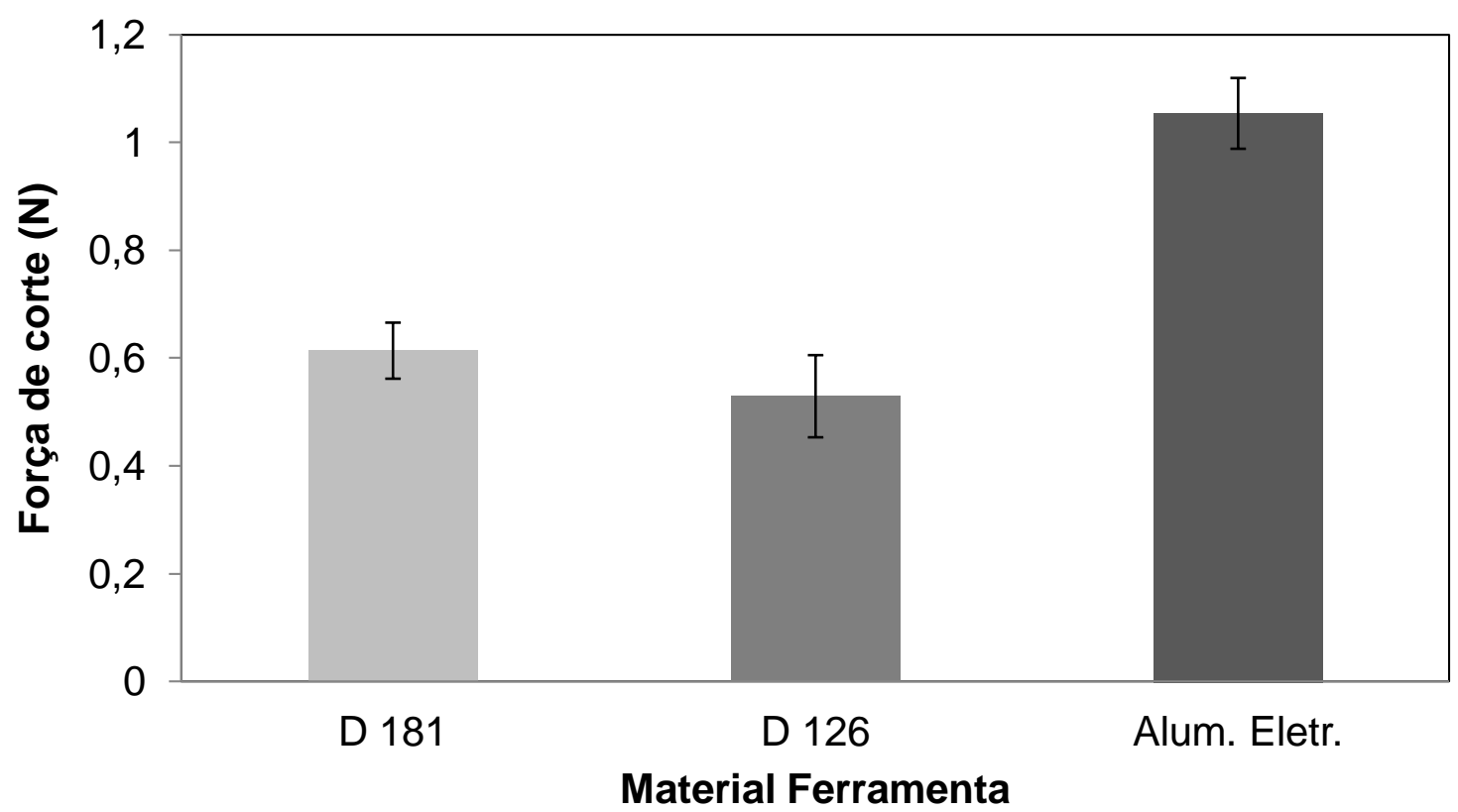

Figura 4.30 - Variação do tamanho de grão e material da ferramenta em função da força de corte.

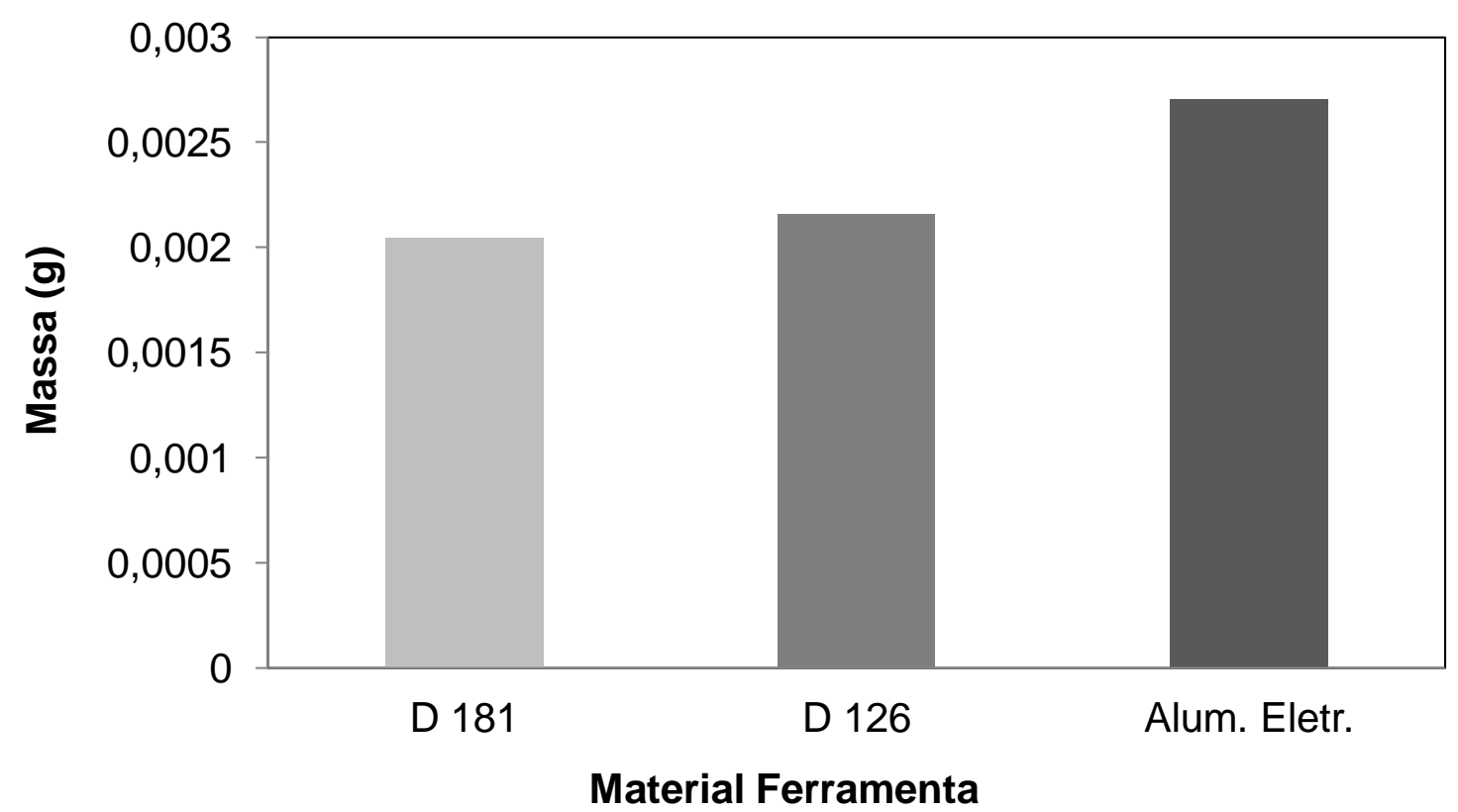

Figura 4.31 - Variação do tamanho de grão e material da ferramenta em função do valor da massa de material aderida.

O MEV das superfícies das três ferramentas (Figura 4.32) demonstrou uma grande porosidade na ferramenta de abrasivo de alumina eletrofundida (Alum. Eletr.). Tal porosidade influenciou diretamente no empastamento da ferramenta sendo observada a maior aderência de material que, além de aderir à superfície, este penetra nos poros levando ao entupimento com o consequente aumento da 
força de corte. Já as ferramentas de abrasivo de diamante e ligante metálico não possuem porosidade, sendo a aderência de material apenas na superfície e nos contornos dos abrasivos, o que justifica o menor empastamento e a menor força de corte.

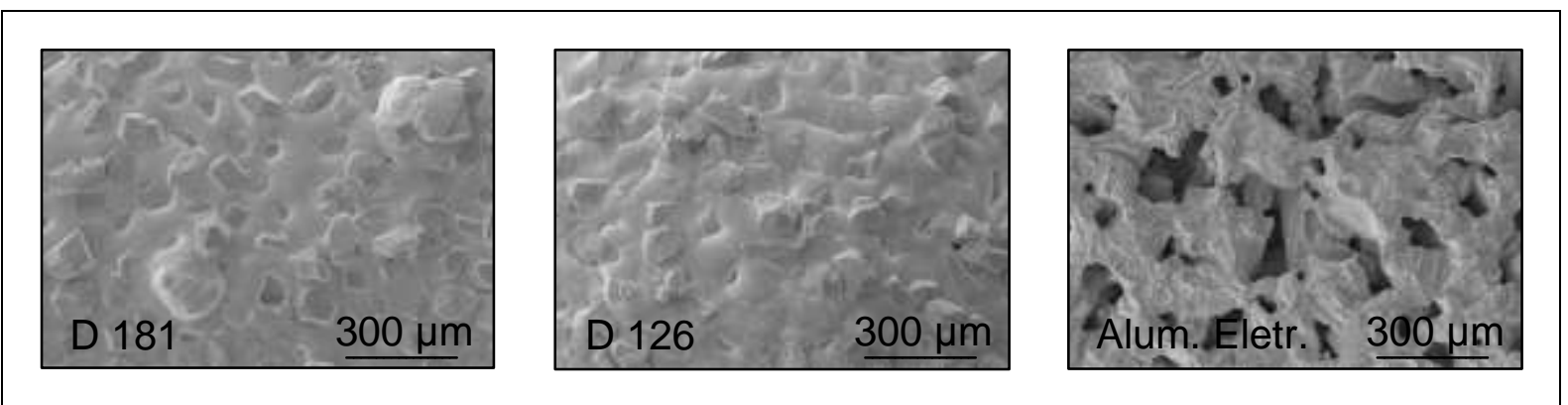

Figura 4.32- MEV das superfícies das ferramentas.

A análise da rugosidade (Figura 4.33) demonstra desvantagem para a ferramenta com menor grão abrasivo de diamante (D 126), esta apresentou o maior valor de Ra, sendo este 5,79 $\mu \mathrm{m}$. Por outro lado, a ferramenta de abrasivo de alumina eletro fundida apresentou o menor valor de Ra, sendo este 2,40 $\mu \mathrm{m}$. Já a ferramenta com o maior grão abrasivo de diamante (D 181) apresenta o valor intermediário de $3,87 \mu \mathrm{m}$.

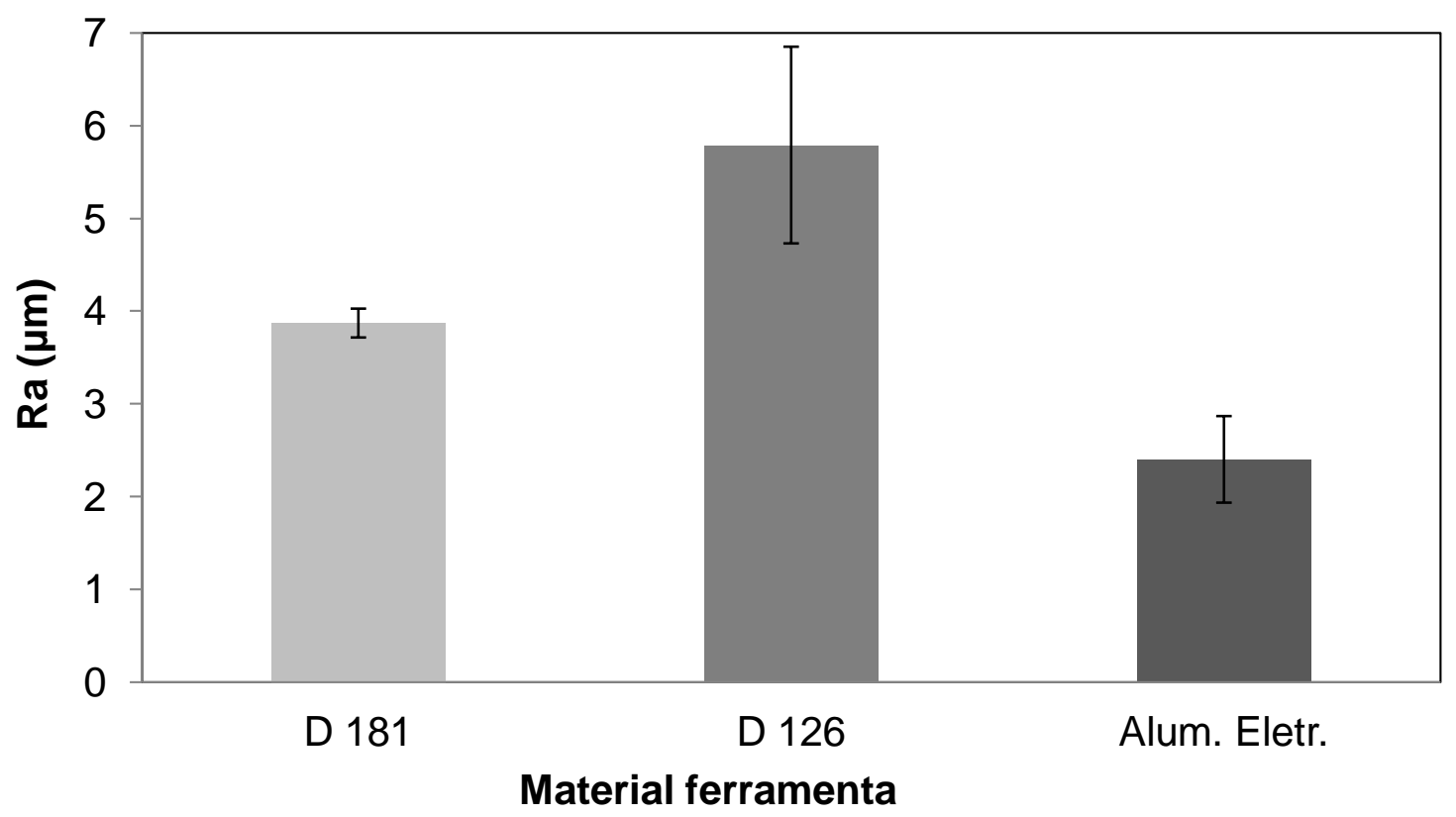

Figura 4.33 - Análise das ferramentas em função da rugosidade média aritmética $(\mathrm{Ra})$. 
A ferramenta de abrasivo de alumina eletro fundida (Alum. Eletr.), demonstrou desvantagem em relação ao lascamento de borda, como pode ser observado na parte superior da imagem da Figura 4.34, apresentando grande quantidade de lascamentos. Em seguida, a ferramenta com o menor tamanho de grão de abrasivo de diamante (D 126) demonstrou um médio lascamento de borda. A melhor resposta foi, então, observada para a ferramenta com o maior tamanho de grão de abrasivo de diamante (D 181), com a menor quantidade observada de lascamentos.

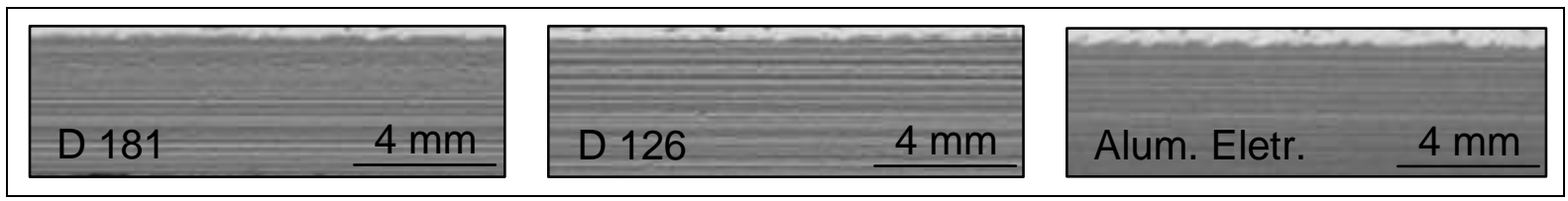

Figura 4.34- Variação do tamanho de grão e material da ferramenta.

A ferramenta com abrasivo de alumina eletrofundida de granulometria \#80 mesh e ligante vitrificado apresentou o menor valor de rugosidade, porém, foi observado para esta a maior força de corte, o maior empastamento e a maior quantidade de lascamentos de borda, que neste caso demonstra desvantagem para a utilização deste tipo de ferramenta.

Já a ferramenta com abrasivo de diamante de granulometria \#120 mesh e ligante metálico apresentou o menor valor de força de corte, porém, foi observado o maior valor de rugosidade, média quantidade de lascamentos de borda e médio empastamento, que também a coloca em desvantagem, porém, ainda pode ser aplicada como uma opção.

Vantagem é, então, atribuída a ferramenta com abrasivo de diamante de granulometria \#80 mesh e ligante metálico, que apresentou menor quantidade de lascamentos e menor empastamento, apesar de não ter obtido os melhores valores de rugosidade e força de corte.

\subsubsection{Resolução da Estratégia de usinagem em verde na fabricação de uma superfície funcional plana}

Este estudo indica vantagem no emprego de ligante B-1007 com a ferramenta de material abrasivo de diamante de \#80 mesh com o ligante metálico e parâmetros de usinagem com velocidade de corte de $7,64 \mathrm{~m} / \mathrm{s}$, profundidade de corte de $1 \mathrm{~mm}$ e 
velocidade de avanço de $100 \mathrm{~mm} / \mathrm{min}$, sendo observados valores de força de corte de $0,614 \mathrm{~N}$ e Ra de $3,87 \mu \mathrm{m}$.

Dessa forma pode ser resolvida a matriz de decisão para estratégia de usinagem em verde para a fabricação de uma barra com uma superfície funcional plana, como é observada na Figura 4.35. 


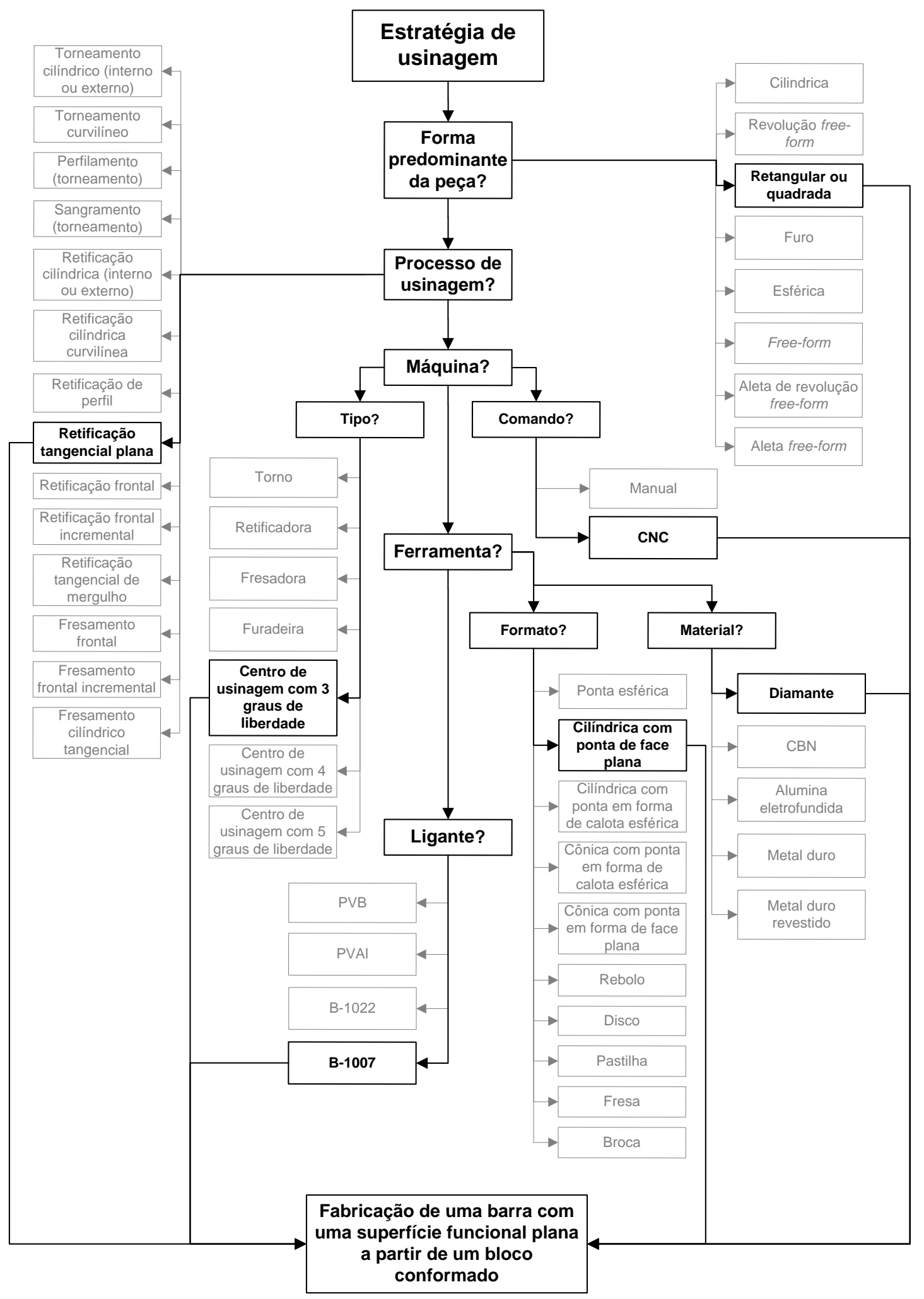

Figura 4.35 - Matriz de decisão para estratégia de usinagem em verde na fabricação de uma barra com uma superfície funcional plana a partir de um bloco conformado. 


\subsubsection{Resultados da estratégia de usinagem em verde na obtenção de um furo}

Os resultados deste estudo avaliaram a aplicação de dois processos de usinagem, retificação frontal e retificação frontal incremental, analisando a diferença da execução de cada processo e o acabamento dos furos relacionado ao lascamento de borda.

Antes da execução do ensaio, um teste com a retificação frontal foi realizado com o intuito de avaliar sua execução na obtenção do furo. Esse demonstrou grande dificuldade, pois com o avanço contínuo da ferramenta e por não possuir saída para o cavaco, provocou grandes lascamentos no bloco levando até a ocorrência da quebra do bloco, como pode ser observado na imagem da Figura 4.36, sendo as diversas tentativas indicadas por setas.

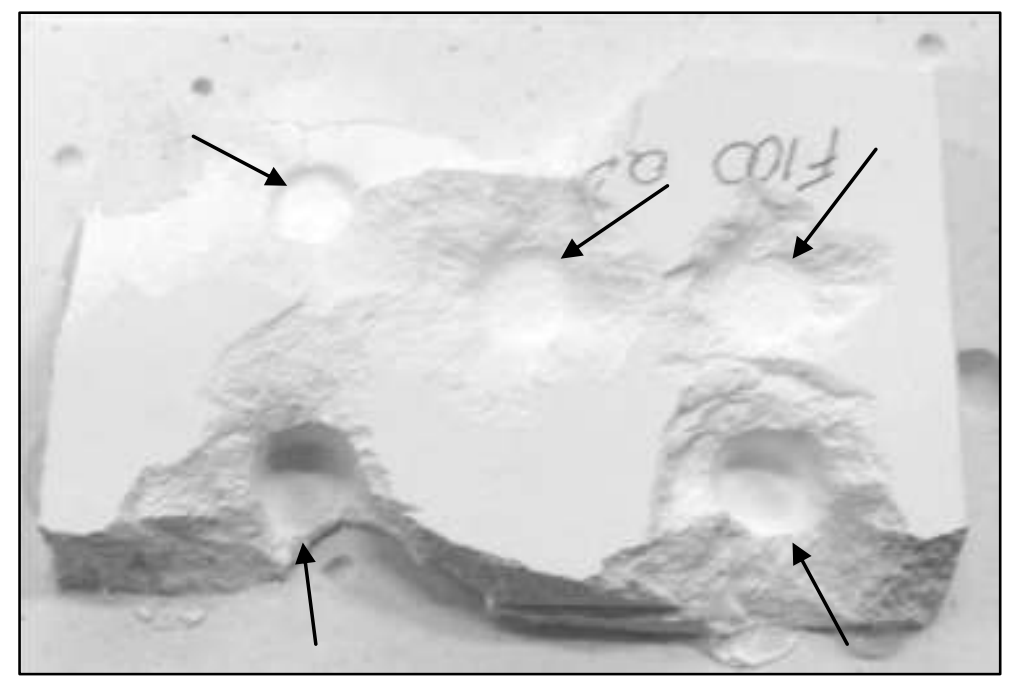

Figura 4.36 - Tentativas de furação com a retificação frontal.

Os lascamentos e as quebras só foram minimizados com uma grande redução da velocidade de avanço (f) da ferramenta e com o processo sendo executado em $1 \mathrm{~mm}$ de profundidade por avanço. Dessa forma, quando a ferramenta atingia $1 \mathrm{~mm}$ de profundidade essa era recuada para uma limpeza do furo, para então se executar um novo avanço de $1 \mathrm{~mm}$, esse processo foi repetido até atingir toda a espessura do bloco. O f foi reduzido até o valor de $2,5 \mathrm{~mm} / \mathrm{min}$, 0 qual foi aplicado na execução do ensaio da retificação frontal para obtenção dos furos. 
Já com a retificação frontal incremental, tal dificuldade não foi pronunciada, pois a remoção de material foi predominantemente realizada com a lateral da ferramenta, que executa o movimento orbital, atingindo o diâmetro final do furo, uma vez que a ferramenta possui um diâmetro menor que o furo a ser executado. Porém, como primeiro é executado um avanço da ferramenta, para atingir a profundidade com a qual a ferramenta irá fazer o seu giro, este teve, também, sua f reduzida para $2,5 \mathrm{~mm} / \mathrm{min}$ com o intuito de evitar uma possível geração de defeitos. Já o f que executa o movimento orbital da ferramenta foi mantido em $50 \mathrm{~m} / \mathrm{min}$.

Ao executar a retificação frontal, para a obtenção dos furos, foi observado grande dificuldade, mesmo com o baixo f. Dos três furos que foram executados, apenas o último foi obtido por completo, como pode ser observado na imagem da vista superior do corpo-de-prova (Figura 4.37). Na execução do primeiro furo, houve a quebra do canto do corpo-de-prova e a operação foi interrompida. Já na execução do segundo furo, ocorreu um grande lascamento da borda superior do furo, por onde começou a entrada da ferramenta, e a operação também foi interrompida. Defeitos deste tipo podem levar ao descarte de uma peça. Com o processo de retificação frontal incremental, foi possível obter os três furos sem a ocorrência de danos aparentes.

Com a imagem da vista inferior do corpo-de-prova (Figura 4.38), foi possível observar o efeito da saída da ferramenta após a execução dos dois processos. A borda de saída do furo obtido com o processo de retificação frontal apresentou um grande lascamento. Já o furo obtido com o processo de retificação frontal incremental causou um lascamento pequeno da borda, que, neste caso, evitaria um possível descarte da peça, diferentemente do processo anterior.

A saída da ferramenta, no final da furação, promoveu o arrancamento do fundo do furo sem que houvesse o término da remoção do material pela usinagem. Desta forma, uma porção de material maior do que o diâmetro da ferramenta foi removido, sendo o responsável pelo lascamento da borda, como pode ser observado nas imagens da Figura 4.39. Este efeito foi observado tanto para a retificação frontal como para a retificação frontal incremental, porém, como a retificação frontal utilizou uma ferramenta de maior diâmetro $(\varnothing 4 \mathrm{~mm})$ em relação à retificação frontal incremental $(\varnothing 3 \mathrm{~mm}$ ), o efeito do lascamento de borda foi maior. Por outro lado, apesar da retificação frontal incremental também ter causado o arrancamento de material, porém menor devido ao menor diâmetro da ferramenta, 0 
movimento orbital da ferramenta na usinagem, para obter o diâmetro desejado, promoveu uma diminuição do efeito de lascamento de borda que havia sido causado.

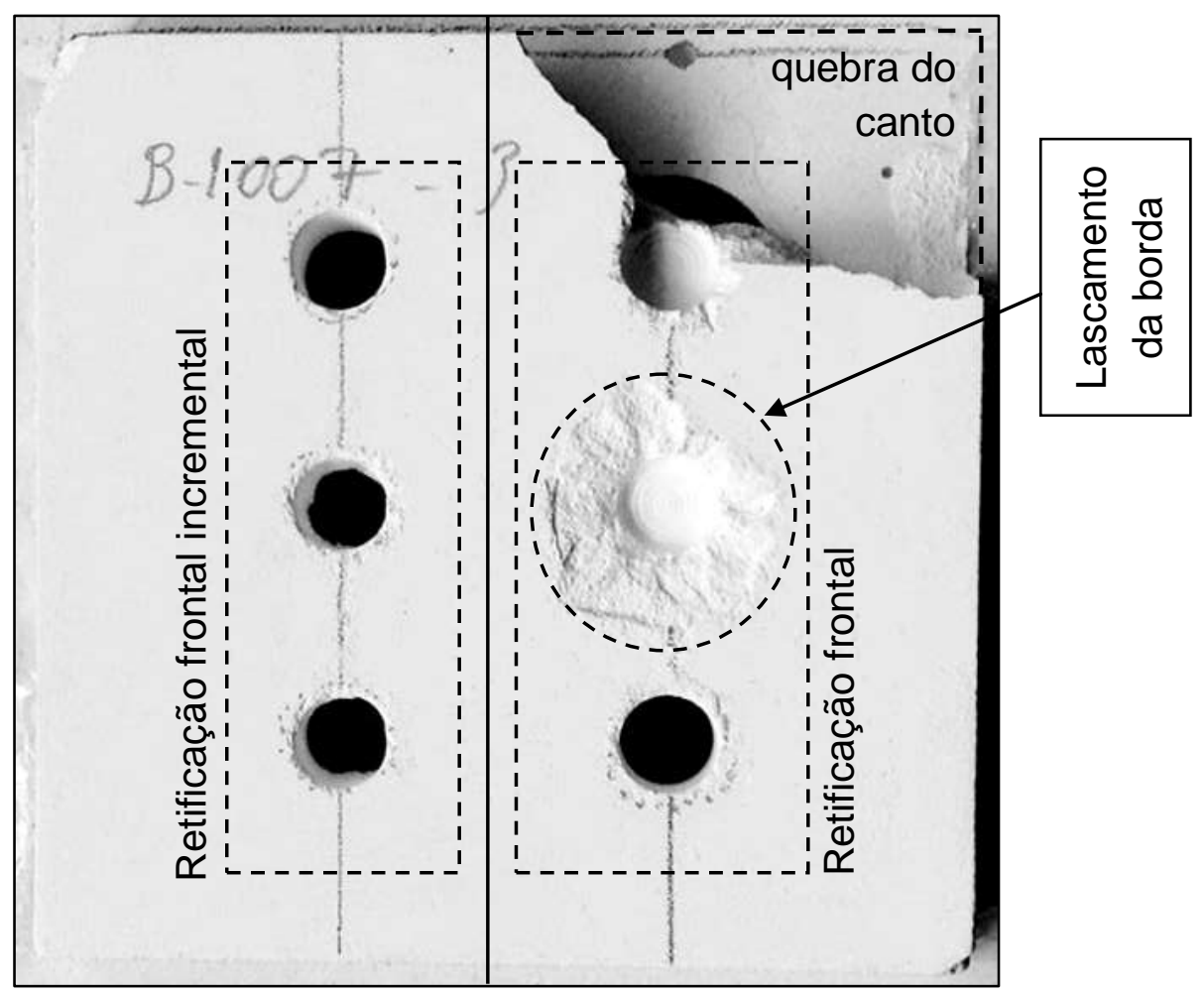

Figura 4.37 - Imagem da vista superior do corpo-de-prova.

No detalhe das furações (Figura 4.40) é possível observar as diferenças entre os lascamentos das bordas deixados pela saída das ferramentas após as furações com os dois processos, sendo observado pequeno lascamento para a retificação frontal incremental e grande lascamento para a retificação frontal.

A retificação frontal incremental, aplicada na obtenção de furos, demonstrou vantagem em relação à retificação frontal, sendo observado baixo lascamento de borda e maior facilidade de execução, sem a presença de defeitos que pudessem levar a um descarte da peça. Já a retificação frontal, apesar de utilizar parâmetros de usinagem que permitissem baixa remoção de material, se demonstrou dificultosa, acarretando grandes lascamentos de borda e até a quebra da lateral do corpo-deprova, o que invariavelmente levaria ao descarte da peça. 


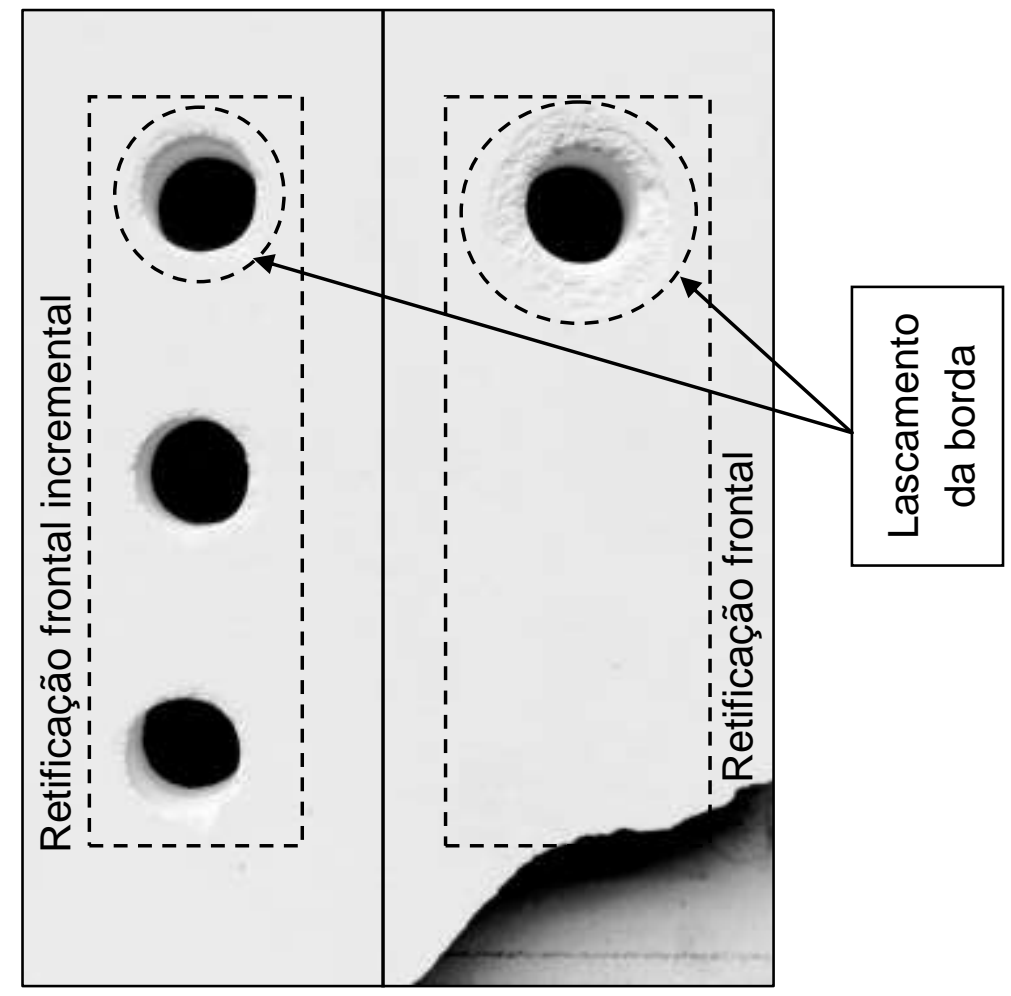

Figura 4.38- Imagem da vista inferior do corpo-de-prova.

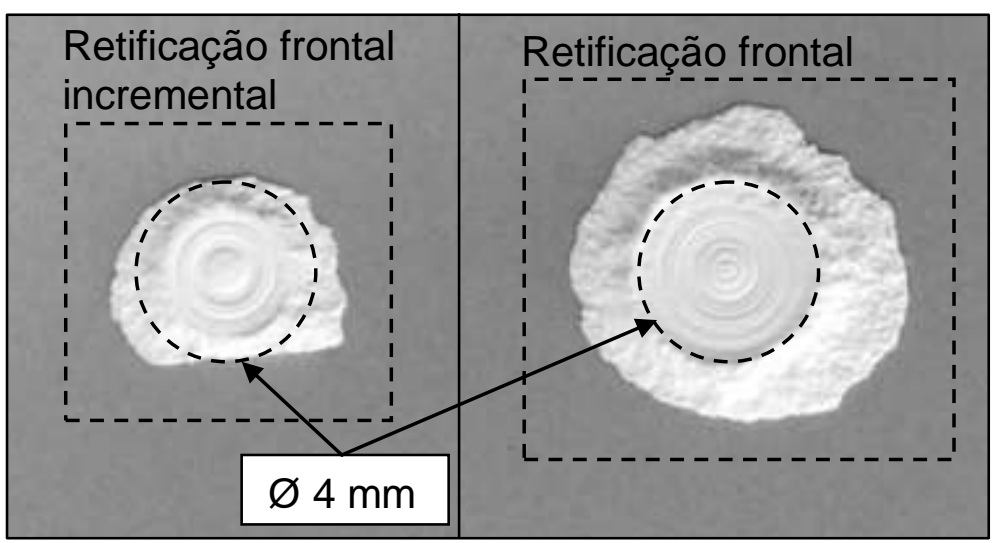

Figura 4.39 - Imagem do fundo dos furos arrancados pelos processos. 


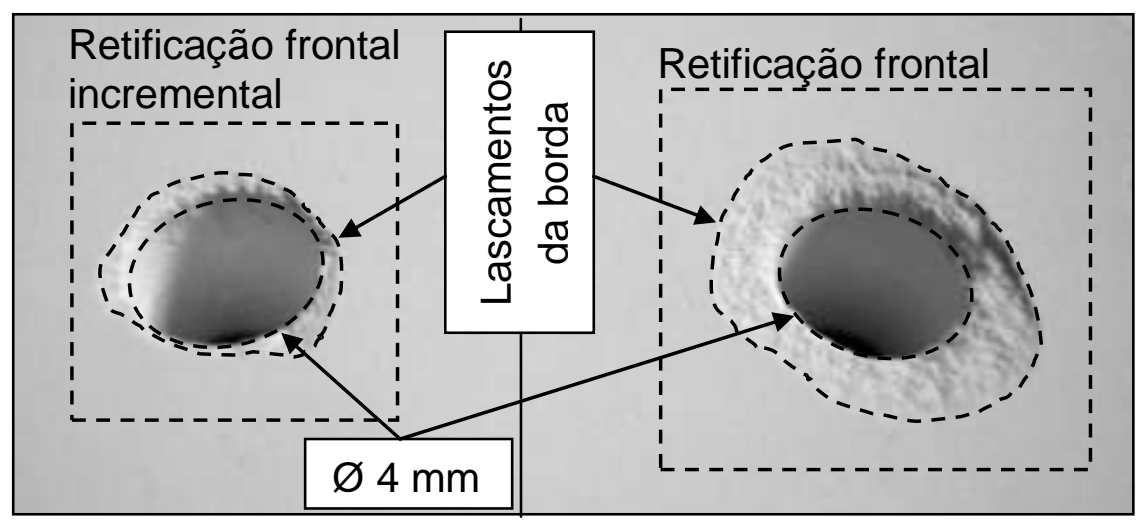

Figura 4.40 - Detalhe das furações obtidas como os dois processos.

\subsubsection{Resolução da estratégia de usinagem em verde na obtenção de um furo}

Este estudo indica vantagem no emprego da retificação frontal incremental, utilizando ferramental com abrasivo de diamante de granulometria \#80 mesh e ligante metálico, quando aplicada na obtenção de furos.

Dessa forma pode ser resolvida a matriz de decisão de estratégia de usinagem em verde na obtenção de um furo, como é observada na Figura 4.35. 


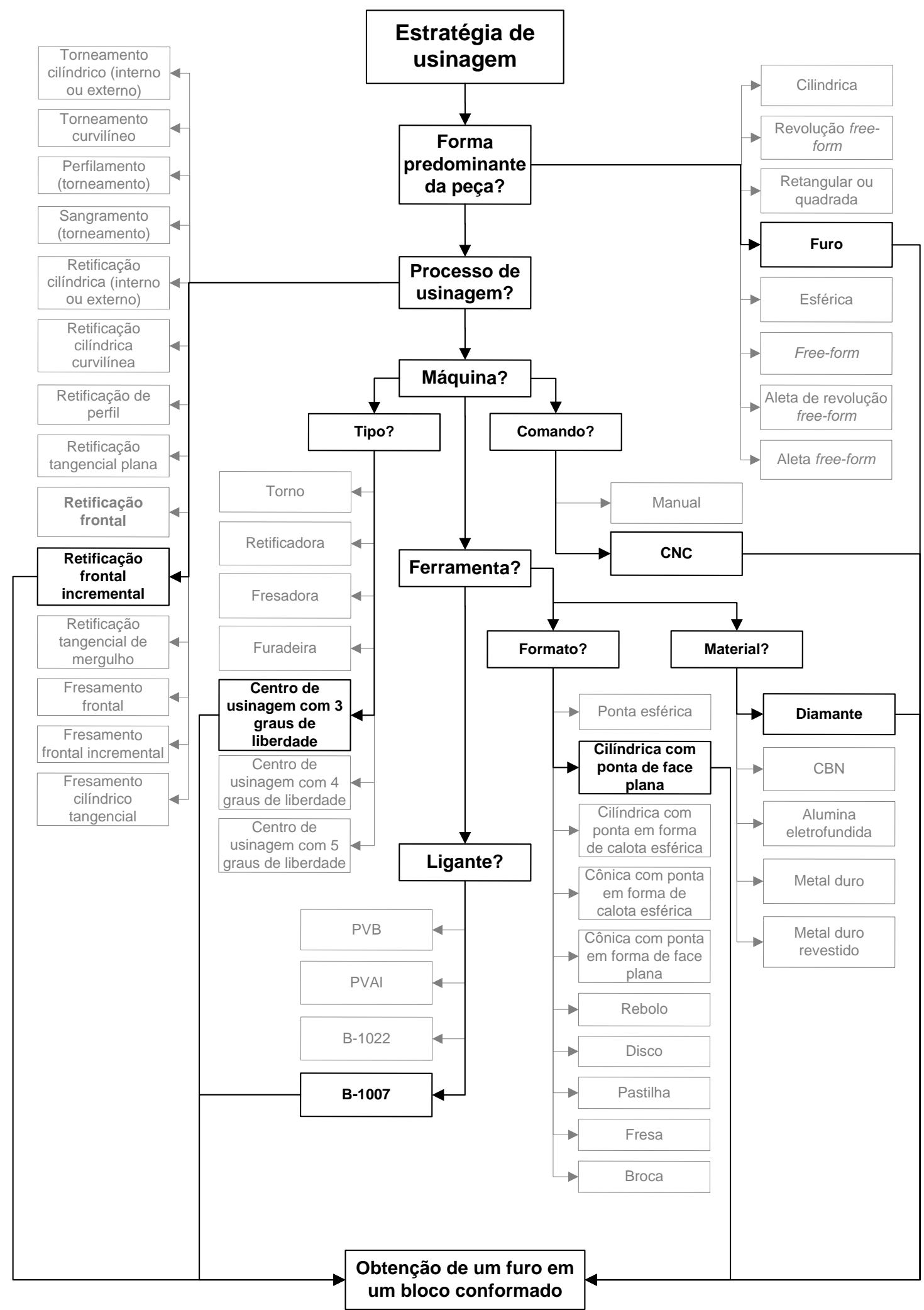

Figura 4.41 - Matriz de decisão para estratégia de usinagem em verde na obtenção de um furo em um bloco conformado. 


\subsubsection{Resultados da estratégia de usinagem em verde na fabricação de um implante dentário conceitual free-form}

A aplicação da matriz de decisão da estratégia de usinagem em verde permitiu a fabricação de um implante dentário conceitual em alumina com sucesso. Os estudos dos ligantes, dos materiais e ligantes para as ferramentas, dos parâmetros de usinagem e dos processos de fabricação, que foram realizados nas matrizes de decisão anteriores, foram de suma importância para a efetivação da fabricação do implante.

A maior dificuldade foi na determinação dos parâmetros de usinagem a serem aplicados ao processo. A baixa rotação do spindle junto com o pequeno diâmetro da ferramenta gerou uma baixa velocidade de corte $\left(v_{c}\right)$ que, neste caso, fez com que os parâmetros de usinagem fossem muito reduzidos.

A divisão da usinagem em etapas se demonstrou uma aliada na fabricação do implante, pois fez com que a base do tarugo cônico permanecesse com uma maior dimensão (maior área de secção transversal), mantendo a maior resistência mecânica possível, enquanto eram realizadas as operações de desbaste e acabamento do corpo inferior do implante. Uma breve sequência da progressão da usinagem é demonstrada na Figura 4.42, onde é possível observar a base do tarugo com maior dimensão enquanto e foram realizadas as operações de desbaste e acabamento do corpo inferior do implante.

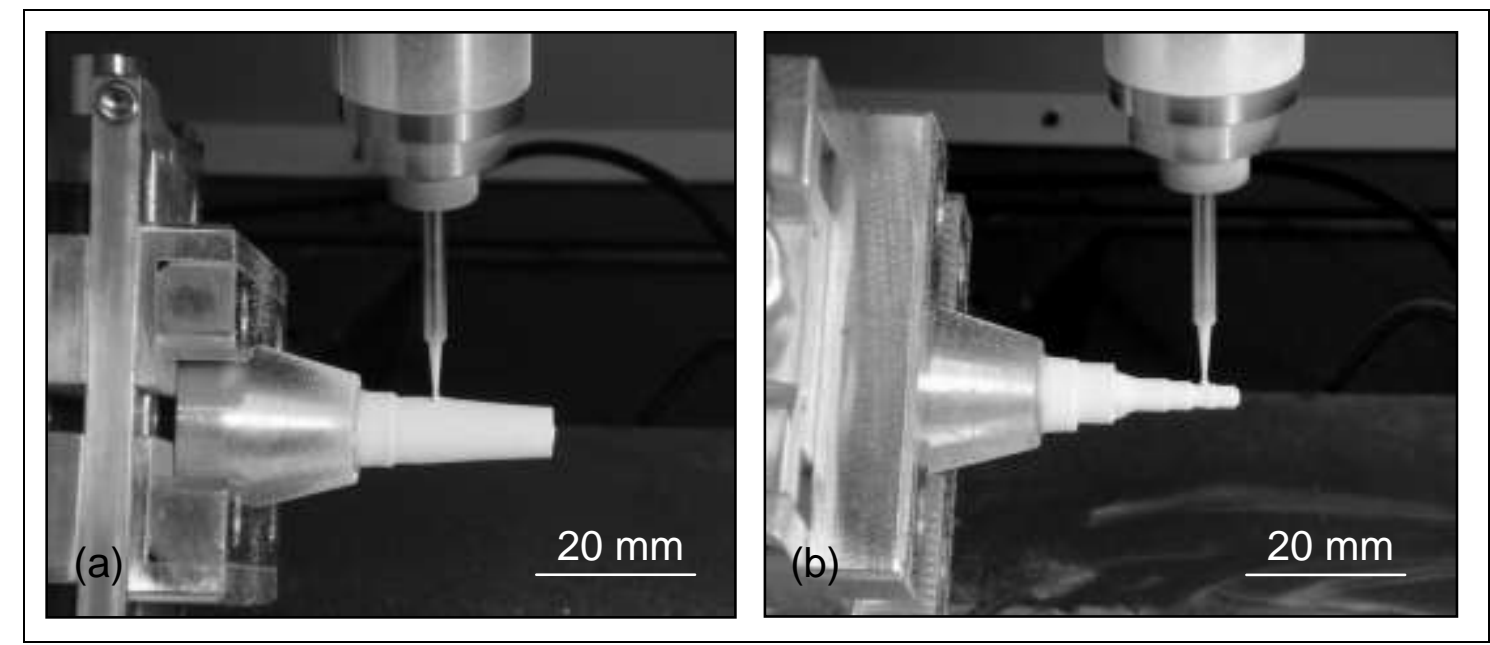

Figura 4.42 - Progressão da usinagem do implante dentario conceitual, sendo (a) operação de desbaste e (b) operação de acabamento. 
Após a finalização das etapas de usinagem com o destacamento do implante usinado do restante do tarugo, esse permaneceu com rebarbas em suas extremidades, as quais foram removidas com o auxilio de uma lixa, de granulometria \#320 mesh, para acabamento. A imagem do implante dentário conceitual usinado em verde pode ser observada na Figura 4.43 (a).

Finalizada a usinagem o implante foi submetido ao processo de sinterização, o qual obteve suas dimensões definitivas devido a retração Figura 4.43 (b). A comparação entre as Figura 4.43 (a) e (b) mostram o efeito da retração causado pela sinterização.

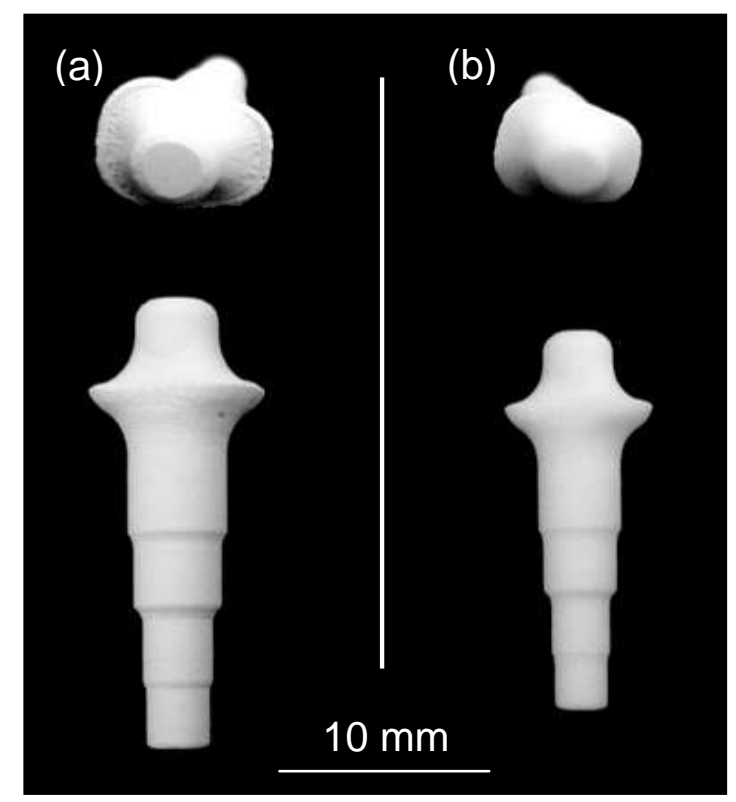

Figura 4.43 - Implante dentário conceitual, em (a) usinado em verde e (b) sinterizado.

A retração causada durante a sinterização deve ser muito bem considerada, uma peça em verde, antes da queima, deve ser aumentada proporcionalmente. Se houver a necessidade de usinagem pós sinterização, então um sobrematerial deve ser considerado.

Sabendo que a resistência mecânica em verde da peça é muito baixa, na faixa entre 2 a $8 \mathrm{MPa}$, defeitos causados pela usinagem, como lascamentos de bordas, trincas e até mesmo a quebra da peça podem ocorrer, caso não seja feito um bom estudo dos parâmetros de usinagem e do material da ferramenta, principalmente. 
Uma quebra do implante durante a usinagem pode ser observada na Figura 4.44, causado pela aplicação de uma profundidade de corte $\left(a_{p}\right)$ de 0,4 mm durante um teste da operação de desbaste, que possivelmente a força de corte gerou uma tensão em uma seção crítica (neste caso devido ao momento fletor próximo à base do implante) que ultrapassou o limite de resistência mecânica do material conformado. Diante deste acontecimento a $a_{p}$ foi reduzida para $0,2 \mathrm{~mm}$, a qual permitiu a usinagem da operação de desbaste por completo.

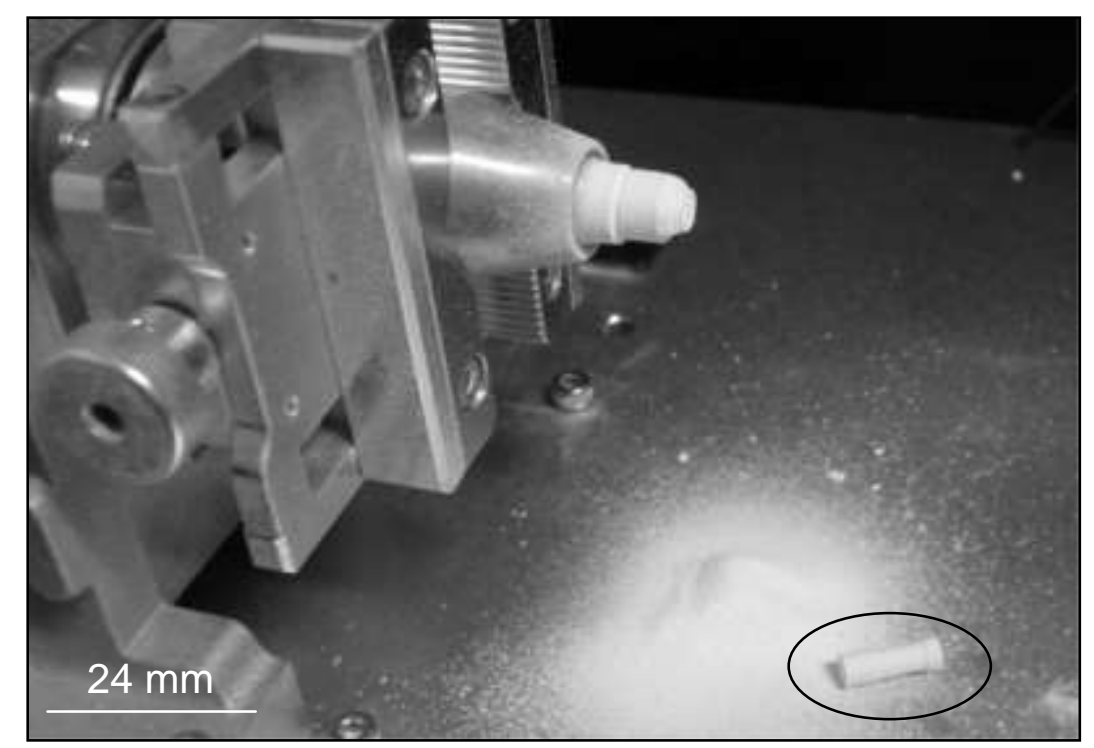

Figura 4.44 - Quebra do implante durante o processo de usinagem quando aplicado um parâmetro de usinagem inadequado. 


\section{CONCLUSÃO}

É concluído que a construção e a aplicação da matriz de decisão para estratégia de usinagem em verde se mostrou satisfatória com os resultados obtidos. Isso validou o conceito proposto quando aplicados nos estudos realizados para a fabricação de peças em formato de barra de perfil retangular, de cilindro, de barra de perfil retangular com uma superfície funcional, de furo e, por fim, na fabricação de uma peça genérica representada por um implante dentário conceitual.

No estudo realizado com a aplicação da matriz de decisão para estratégia de usinagem em verde na fabricação de barras de perfil retangular (estudo preliminar), foi observada vantagem no emprego de ligante PVB (solúvel em álcool) e ferramenta com abrasivo de CBN (granulometria \#80 mesh) com ligante metálico (níquel eletrodepositado). Valores extremos de $190 \mathrm{MPa}$ foram atingidos, quando aplicados os parâmetros de usinagem de velocidade de corte de $3,82 \mathrm{~m} / \mathrm{s}$, velocidade de avanço de $100 \mathrm{~mm} / \mathrm{min}$ e profundidade de corte de $1 \mathrm{~mm}$, contra $145 \mathrm{MPa}$ do ligante PVAI com ferramenta de diamante utilizando os mesmos parâmetros.

Já no estudo realizado com a aplicação da matriz de decisão para estratégia de usinagem em verde na fabricação de cilindros, foi obtido vantagem para o pó preparado com ligante solúvel em água a base de acrílico (B-1007), seco e granulado a mão, e prensado isostaticamente a $200 \mathrm{MPa}$, usinado utilizando rebolo de alumina eletrofundida (granulometria \#80 mesh) com ligante vitrificado. Foi obtido resistência média em cilindros de 280,1 $\mathrm{MPa}$ e com pico em 301,5 $\mathrm{MPa}$. Na usinagem destes corpos foi consumida potência de corte de 220,419 W, para taxa de remoção $10.000 \mathrm{~mm}^{3} / \mathrm{min}$, e obtido Ra de $0,761 \mu \mathrm{m}$.

Para a fabricação de barras com formato de perfil retangular de uma superfície funcional, com o estudo da aplicação da matriz de decisão para estratégia de usinagem em verde, foi demonstrado vantagem para a utilização de ferramenta de abrasivo de diamante (granulometria \#80 mesh) com ligante metálico (níquel eletrodepositado) quando aplicada na usinagem de pó preparado com ligante solúvel em água a base de acrílico (B-1007), seco e granulado a mão, e prensado isostaticamente a $200 \mathrm{MPa}$. Valores de força de corte de $0,614 \mathrm{~N}$ e Ra de $3,87 \mu \mathrm{m}$ foram atingidos, quando aplicado os parâmetros de usinagem de velocidade de corte de $7,6 \mathrm{~m} / \mathrm{s}$, velocidade de avanço de $100 \mathrm{~mm} / \mathrm{min}$ e profundidade de corte de $1 \mathrm{~mm}$, sendo observado baixo lascamento da borda e empastamento. 
$\mathrm{Na}$ furação, com o estudo da aplicação da matriz de decisão para estratégia de usinagem em verde, foi demonstrada vantagem na aplicação do processo de retificação frontal incremental, com está foi possível obter um furo com facilidade e apresentado baixo lascamento da borda na saída da ferramenta. Sendo este estudo realizado com os resultados obtidos das matrizes de decisão anteriores.

A aplicação da matriz de decisão de estratégia de usinagem em verde, utilizando os resultados obtidos das matrizes de decisão anteriores, permitiu a fabricação de um implante dentário conceitual, em alumina com ligante acrílico B1007 prensado a $200 \mathrm{MPa}$, com sucesso.

$\mathrm{Da}$ análise dos estudos realizados, pode-se concluir que toda a manufatura (materiais, ferramentas, equipamentos, parâmetros de corte e ligantes) interfere de sobremaneira nas propriedades mecânicas e no acabamento da peça e devem ser consideradas no projeto de um produto.

Por fim, a aplicação da matriz de decisão para estratégia de usinagem em verde faz com que o projetista reflita sobre todas as possibilidades para rota de manufatura e apresente respostas às diferentes possibilidades. Ao fazer 0 planejamento da manufatura baseado na disponibilidade de recursos disponível é possível, também, fazer a consideração de vantagens e prejuízos em relação às decisões tomadas. 


\section{SUGESTÕES PARA TRABALHOS FUTUROS}

- Fabricação de um rebolo, para a retificação cilíndrica externa, com abrasivo de diamante de granulometria \#80 mesh e ligante metálico, para analisar sua influência na resistência mecânica e na rugosidade.

- Aplicação de uma maior velocidade de corte na usinagem quando aplicado das ferramentas pontas montada, por meio de um spindle de alta rotação, para analisar sua influência na rugosidade, força de corte e empastamento.

- Obtenção de pó por spray-drier da mistura com o ligante que obteve a melhor resposta, para analisar a influência desse método nas propriedades mecânicas. 



\section{REFERÊNCIAS BIBLIOGRÁFICAS}

AGARWAL, S.; RAO, P. V. Experimental investigation of surface/subsurface damage formation and material removal mechanisms in $\mathrm{SiC}$ grinding. International Journal of Machine Tools \& Manufacture, v. 48, p. 698-710, 2008.

ANDER, H.; LEHMANN, J.; ZIEGLER, G. Improvement of mechanical properties of green powder compacts by using novel binder systems. Key Engineering Materials, v. 132-136, p. 378-381, 1997.

BESSHIA, T.; SATOB, T.; TSUTUIB, I. Machining of alumina green bodies and their dewaxing. Journal of Materials Processing Technology, v. 95, p. 133-138, 1999.

BIRKBY, I. Factors affecting the machinability of fine ceramic powder compacts. British Ceramic Transactions, v. 23, n. 5, p. 183-186, 1994.

BOCH, P.; NIÈPCE, J.C. Ceramic Materials: Processes, Properties, and Applications, 2007.

BÖRGER, A. et al. Fracture of green and sintered ceramic bodies. Key Engineering Materials, v. 223, p. 83-90, 2002.

BORTZMEYER, D.; LANGGUTH, G.; ORANGE, G. Fracture Mechanics of Green Products. Journal of the European Ceramic Society, v. 11, p. 9-16, 1993.

BUKVIC, G. et al. Green machining oriented to diminish density gradient for minimization of distortion in advanced ceramics. Machining Science and Technology, v. 16, p. 228-246, 2012.

BUKVIC, G. Usinagem a verde voltada à melhoria da distorção e acabamento superficial de cerâmicas sinterizadas. 2011. 106 f. Dissertação (Mestrado em Engenharia Mecânica) - Faculdade de Engenharia, Universidade Estadual Paulista, Bauru, 2011. 
CARRUM, S. E.; TORRES, T. L.; PÉREZ, P. V. Group technology: Technique with comparisons. IEE Computer Society, p. 330-335, 2007.

DAVIS, T.; SELEP, E. Group technology for high-mix printed circuit assembly. Electronic manufacturing technology symposium, p. 264-269, 1990.

DEGNAN, C. C.; KENNEDY, A. R.; SHIPWAY, P. H. Relationship between physical structure and machinability of green compacts. Powder Metallurgy, v. 50, n. 1, p. 14-20, 2007.

DESFONTAINES, M. et al. Characterization of the green machinability of AIN powder compacts. Journal of the European Ceramic Society, v. 25, p. 781-791, 2005.

DHARA, S.; SU, B. Green machining to net shape alumina ceramics prepared using different processing routes. International Journal of Applied Ceramic Technology, v. 2, n. 3, p. 262-270, 2005.

EL-WARDANY, E. T. et al. Optimum process parameters to produce green ceramic complex parts. CIRP Annals - Machining Technology, v. 58, p. 109-112, 2009.

ELLAKWA, A. et al. Influence of implant abutment angulations on the fracture resistance of overlaying CAM-milled zirconia single crowns. Australian Dental Journal, v. 56, p. 132-140, 2011.

FANTOZZI, G. et al. Advanced ceramic materials: summary of possible applications. Materials: Science and Engineering, 1997.

FECOVA, V. et al. Computer aided manufacturing process planning by group technology application. Proceedings of 15th International Conference on Intelligent Engineering Systems INES 2011, Poprad, 2011, p. 81-84, ISBN 978-1-4244-8955-8.

FERRARESI, D. Fundamentos da usinagem dos metais. Editora Edgard Blücher, São Paulo, 2009. 751p. ISBN 978-85-212-0257-8. 
FILSER, F.; KOCHER, P.; GAUCKLER, L. F. Net-shaping of ceramic components by direct ceramic machining. Assembly Automation, v. 23, n. 4, p. 382-390, 2003.

FORTULAN, C. A.; PURQUERIO, B. M. The influence of methods of injection moulding and isostatic pressing on structural ceramics performance. Cerâmica, v. 44, n. 289, p. 1-10, Sept./Oct. 1998.

KAMBOJ, R. K.; DHARA, S.; BHARGAVA, P. Machining behavior of green gelcast ceramics. Journal of the European Ceramic Society, v. 23, p. 1005-1011, 2003.

KING, G. A. Ceramic technology and processing. Noyes Publication: William Andrew Publishing, Norwich, New York, 2002. 528 p. ISBN 0-8155-1443-3.

KLOCKE, F.; GERENT, O.; SCHIPPERS, C. Machining of advanced ceramics in the green state. Ceramic Forum International, v. 74, n. 6, p. 288-290, 1997.

$\mathrm{KOH}, \mathrm{Y}$;; HALLORAN, J. W. Green machining of a thermoplastic ceramic ethylene ethyl acrylate/isobutyl methacrylate compound. Journal of the American Ceramic Society, v. 87, n. 8, p. 1575-1577, 2004.

KUMAR, D. B. R. et al. Acrylic co-polymer emulsion binders for green machining of ceramics. European Polymer Journal, v. 36, p. 1503-1510, 2000.

LEE, D. G. et al. Micro-drilling of alumina green bodies with diamond grit abrasive micro-drills. International Journal of Machine Tools \& Manufacture, v. 43, p. 551558, 2003.

LEE, H. G.; LEE, D. G. Tool life model for abrasive wet micro-drilling of ceramic green bodies. International Journal of Machine Tools \& Manufacture, v. 44, p. 839-846, 2004.

LI, J. Z. et al. Micro machining of pre-sintered ceramic green body. Journal of Materials Processing Technology, v. 212, p. 571-579, 2012. 
LINDQVIST, K.; CARLSTRÖM, E. Green machining of alumina formed by CIP, starch consolidation and latex slip casting. Key Engineering Materials, v. 206-213, p. 301-304, 2002.

LIU, H. el al. Machining behavior of green rbsc body prepared by gel-casting, Key Engineering Materials, v. 434-435, p. 853-855, 2010.

LUTHARDT, R. G. et al. CAD/CAM-machining effects on Y-TZP zirconia. Dental Materials, v. 20, p. 655-662, 2004.

MARGARIDO, A. Estudo da influência da força de corte da usinagem a verde nas propriedades mecânicas de cerâmicas sinterizadas. 2011. 115 f. Dissertação (Mestrado em Engenharia Mecânica e Área de Concentração em Projeto Mecânico) - Escola de Engenharia, Universidade de São Paulo, São Carlos, 2011.

NAITO, M. et al. Powder Processing Issues for High Quality Advanced Ceramics. KONA Powder and Particle Journal, n. 28, p. 146-154, 2010.

NAMPI, P. P. et al. Effect of surface roughness on grain growth and sintering of alumina. Bull. Mater. Sci., v. 34, n. 4, p. 799-804, July 2011.

NG, S. H.; HULL, J. B.; HENSHALL, J. L. Machining of novel alumina/cyanoacrylate green ceramic compacts. Journal of Materials Processing Technology, v. 175, p.299-305, 2006.

NUNN, S.; KIRBY, G. H. Green machining of gelcasting ceramic materials. Oak Ridge National Laboratory, Oak Ridge, TN 3783 1-6087.

PFRENGLE, A. et al. Optimizing net-shape ceramics for green machining. International journal of Applied Ceramic Technology, v. 7, n. 2, p. 189-196, 2009. 
PRABHAKARAN, k. et al. Gelcasting of alumina using urea-formaldehyde III. Machinable green bodies by copolymerization with acrylic acid. Ceramics International, v. 27, p. 185-189, 2001.

Rahaman MN. Ceramic processing and sintering. Second Edition. 270 Madison Avenue, New York, NY 10016, USA: Marcel Dekker, Inc; 2003.

REED J.S. Principles of Ceramic Processing. 2.ed. Nova York: John Wiley, 1995.

REICH, S.; PETSCHELT, A.; LOHBAUER, U. The effect of finish line preparation and layer thickness on the failure load and fractography of $\mathrm{ZrO} 2$ copings. The Journal of Prosthetic Dentistry, v. 99, n. 5, 2008.

REN, C. Z. et al. A new shaping model for green ceramic balls. Journal of Materials Processing Technology, v. 129, p. 423-426. 2002.

RICHERSON, D. W. Modern ceramic engineering: properties, processing and use in design. $2^{\mathrm{a}}$ ed., Marcel Dekker, Inc. USA, 1992.

RITZHAUPT-KLEISSL, H. J. et al. Net Shape Reaction Bonded Ceramic Micro Parts by Mechanical Microstructuring. Advanced Engineering Materials, v. 8, n. 10, p. 983-988, 2006.

RÖDEL, J. et al. Development of a roadmap for advanced ceramics: 2010-2025. Journal of the European Ceramic Society, v. 29, p. 1549-1560, 2009.

SATO, T.; BESSHI, T.; MATSUI, M. A new near net-shape forming process for alumina. Journal of Materials Processing Technology, v. 79, p. 125-132, 1998.

SCHELLER, W. L. Conventional machining of green aluminum/aluminum nitride ceramics. The Ohio Journal of Science, v. 94, n.5, p.151-154, 1994.

SHEPPARD, L. M. Green machining: tools and considerations for machining unfired ceramic parts. Ceramic Industry, v. 149, n. 6, p. 65-77, 1999. 
SHEPPARD, L. The challenges of machining ceramics. American Ceramic Society Bulletin, v. 71, n. 11, p. 1590-1610, nov., 1992.

SONG, J. H.; EVANS, J. R. G. On the Machinability of Ceramic Compacts. Journal of the European Ceramic Society, v. 17, p. 1665-1673, 1997.

SU, B.; DHARA, S.; WANG, L. Green ceramic machining: a top-down approach for the rapid fabrication of complex-shaped ceramics. Journal of the European Ceramic Society, v. 28, p. 2109-2115, 2008.

TAKTAK, R.; BAKLOUTI, S.; BOUAZIZ, J. Effect of binders on microstructural and mechanical properties of sintered alumina. Materials characterization, v. 62, p. 912916, 2011.

TANAKA, S. et al. Effect of internal binder on microstructure in compacts made from granules. Journal of the European Ceramic Society, v. 27, p. 873-877, 2007.

TUERSLEY, I. P.; JAWAID, A.; PASHBY, I. R. Review: Various methods of machining advanced ceramic materials. Journal of Materials Processing Technology, v. 42, p. 377-390, 1994.

WANG, L.; ALDINGER, F. Near-net shape forming of advanced ceramics. Advanced Engineering Materials, v. 2, n. 3, p. 110-113, 2000.

WESTERHEIDE, R. et al. Advances in characterization of machined green compacts. Journal of the European Ceramic Society, v. 17, p. 467-472, 1996.

YAN, J.; LI, W. Group Technology Based Feature Extraction Methodology for Data Mining. IEE Computer Society, p. 235-239, 2008.

YOON, C. B. et al. Windmill-type ultrasonic micromotor fabricated by thermoplastic green machining process. Sensors and Actuators A, v. 134, p. 519-524, 2007. 
ZHANG, W. X. et al. Shaping of green ceramic balls and precision lapping of ceramic balls for ceramic ball bearings. Key Engineering Materials, v. 259-260, p. 471-475, 2004. 

ANEXOS
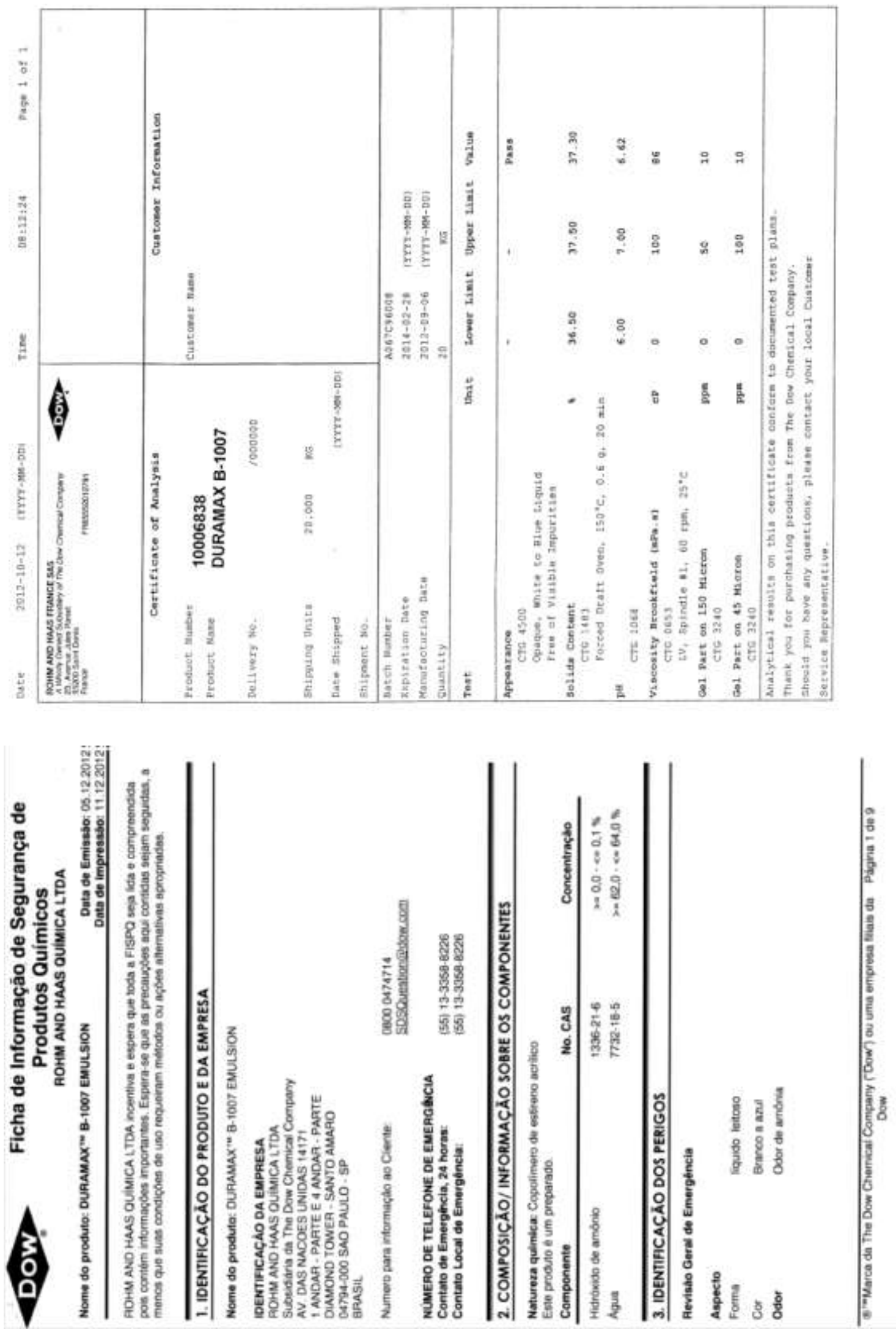


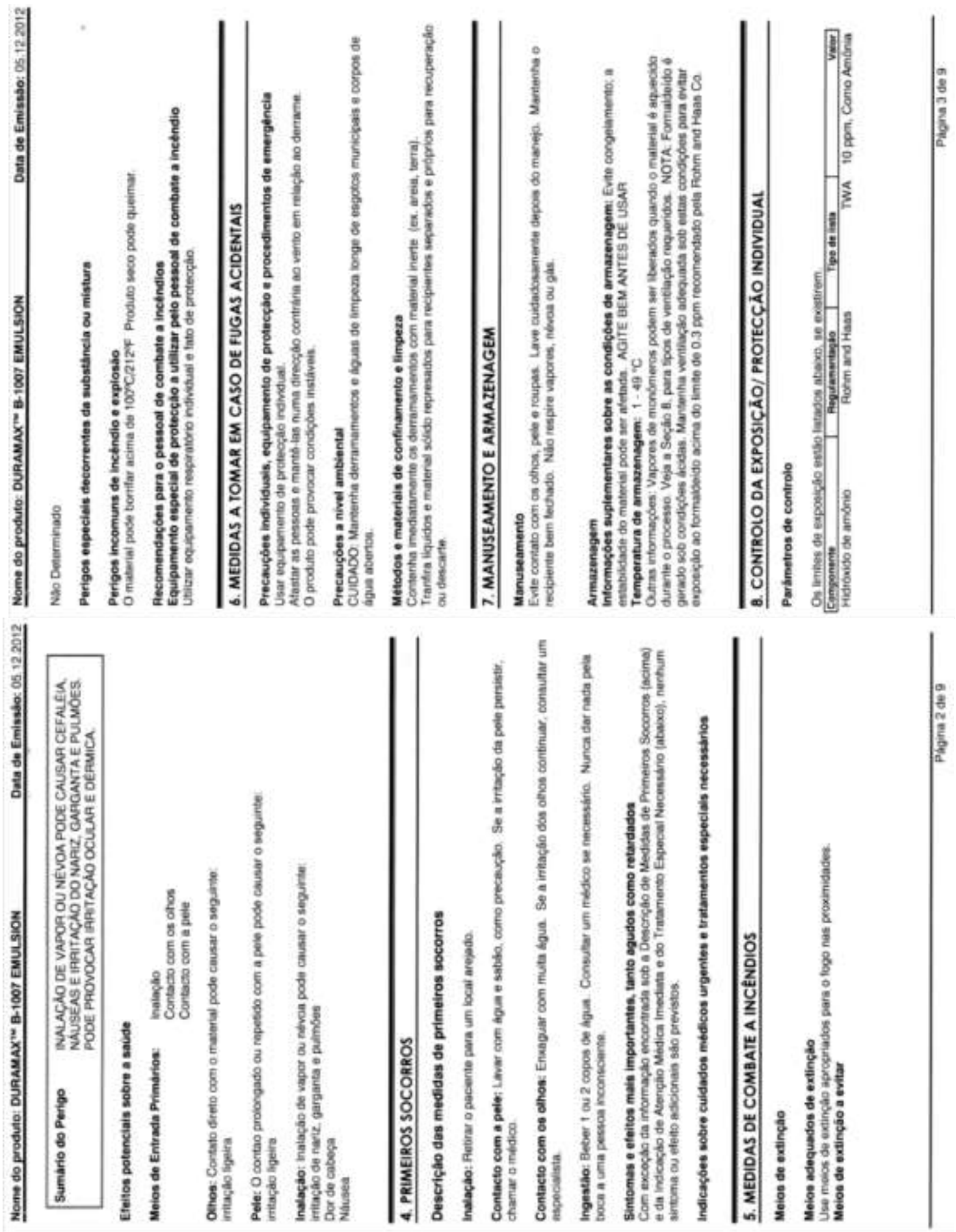



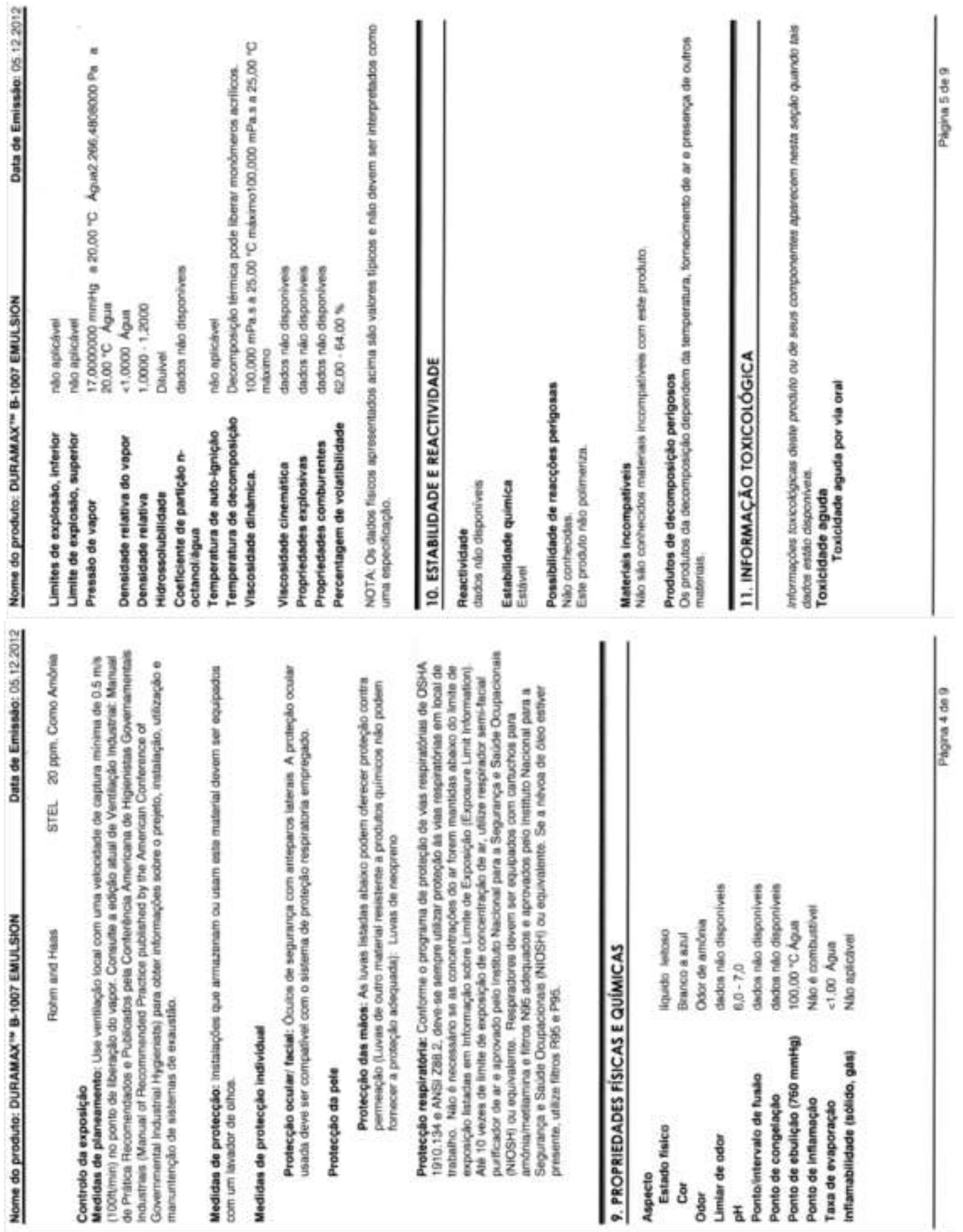


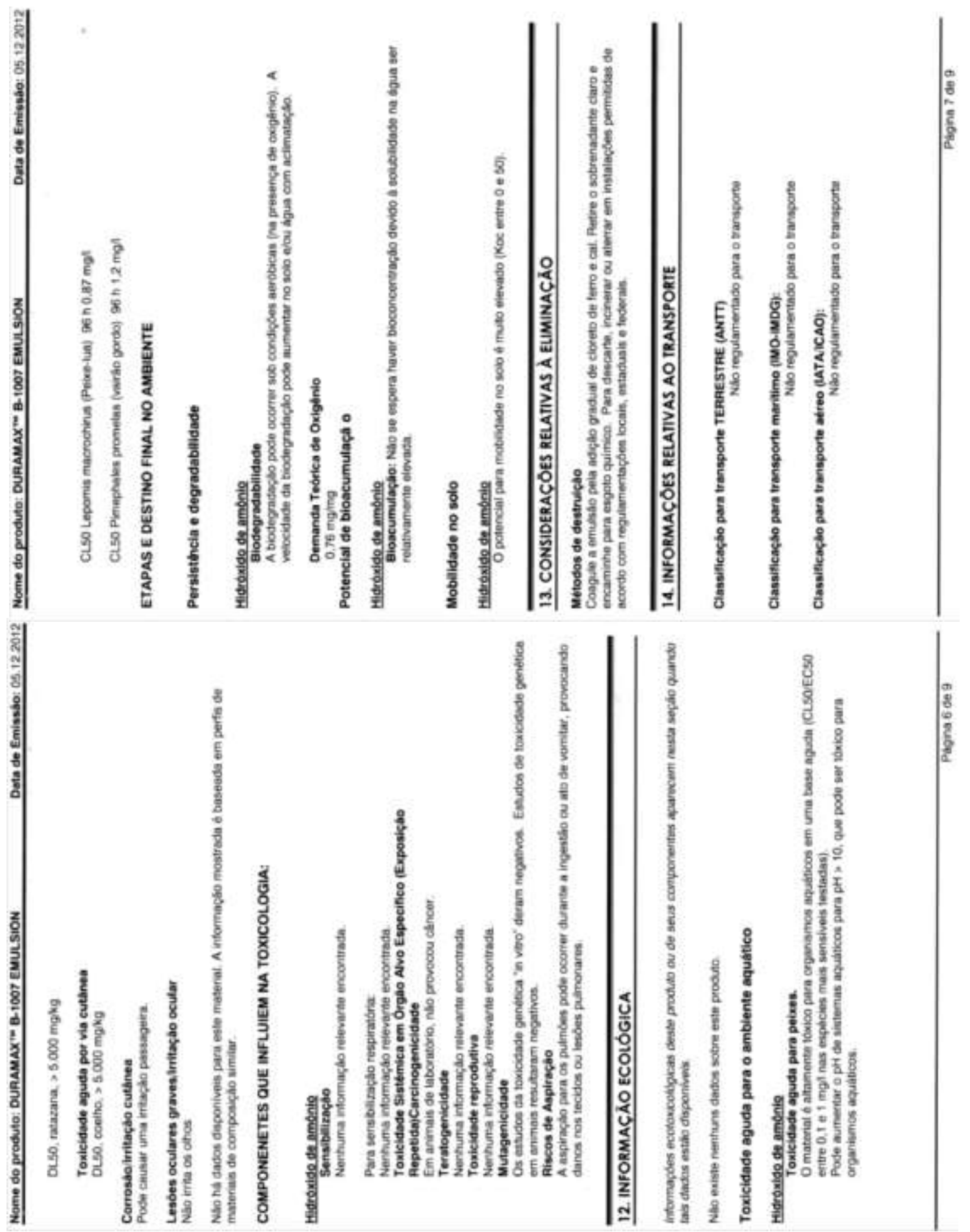




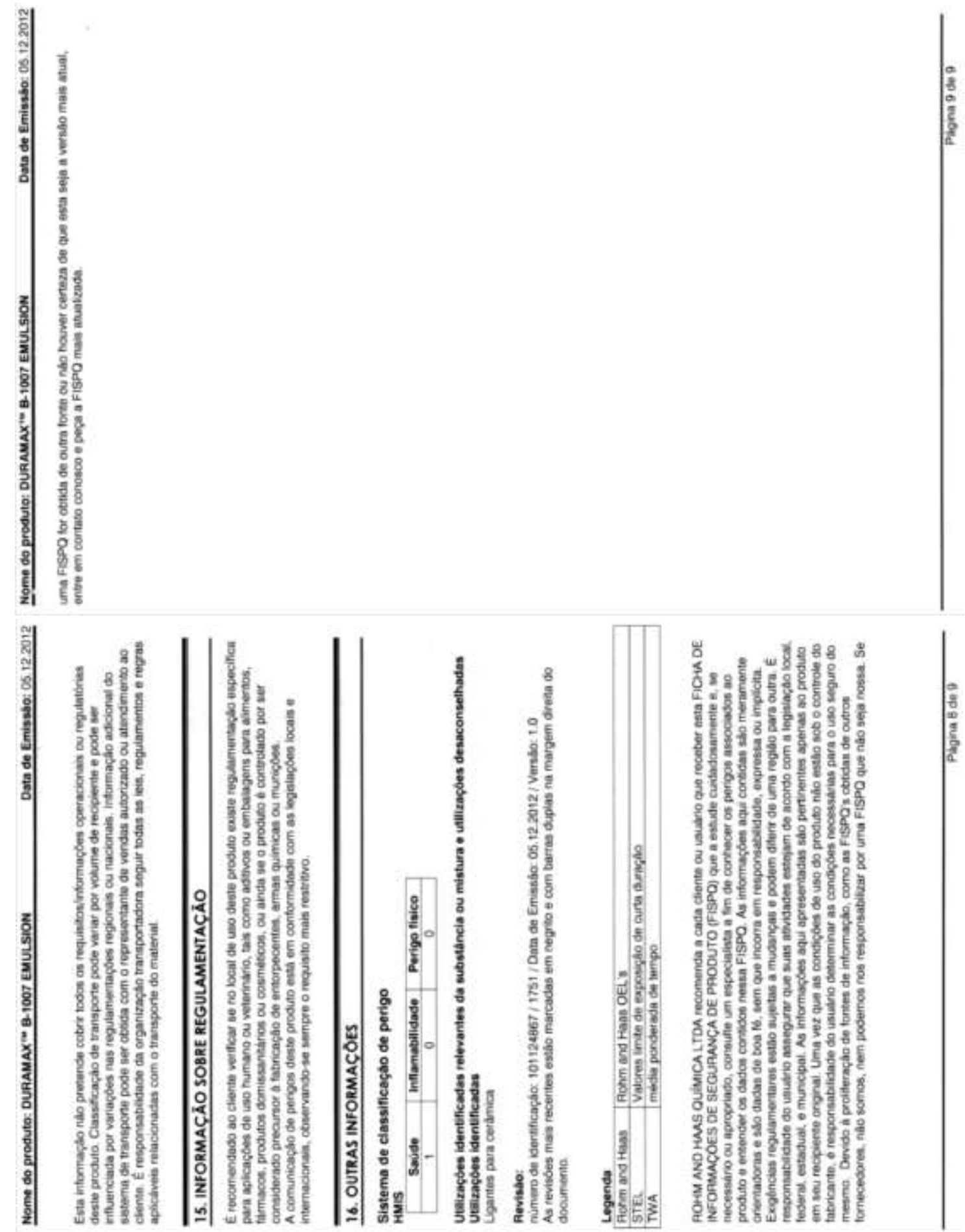



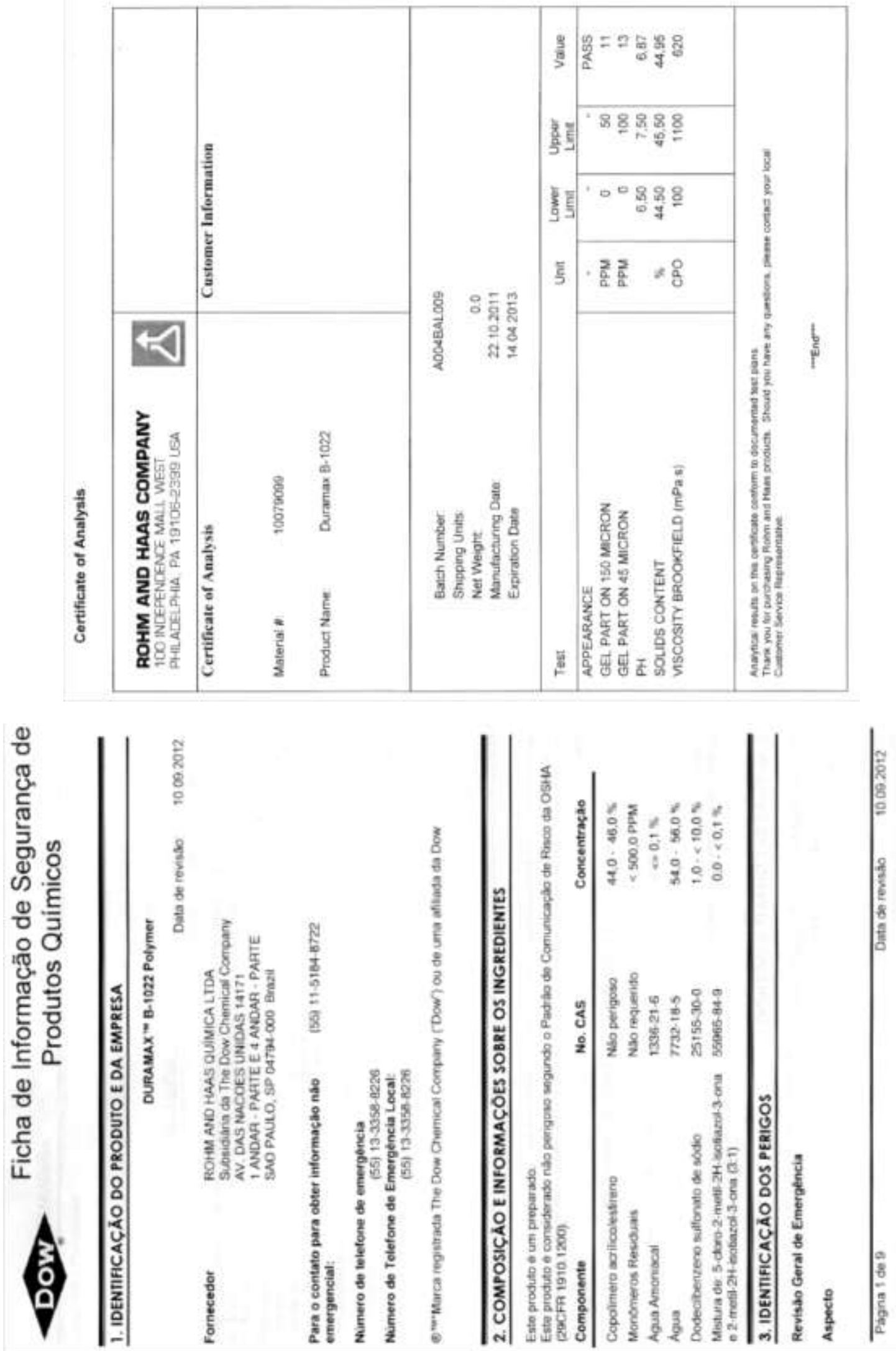


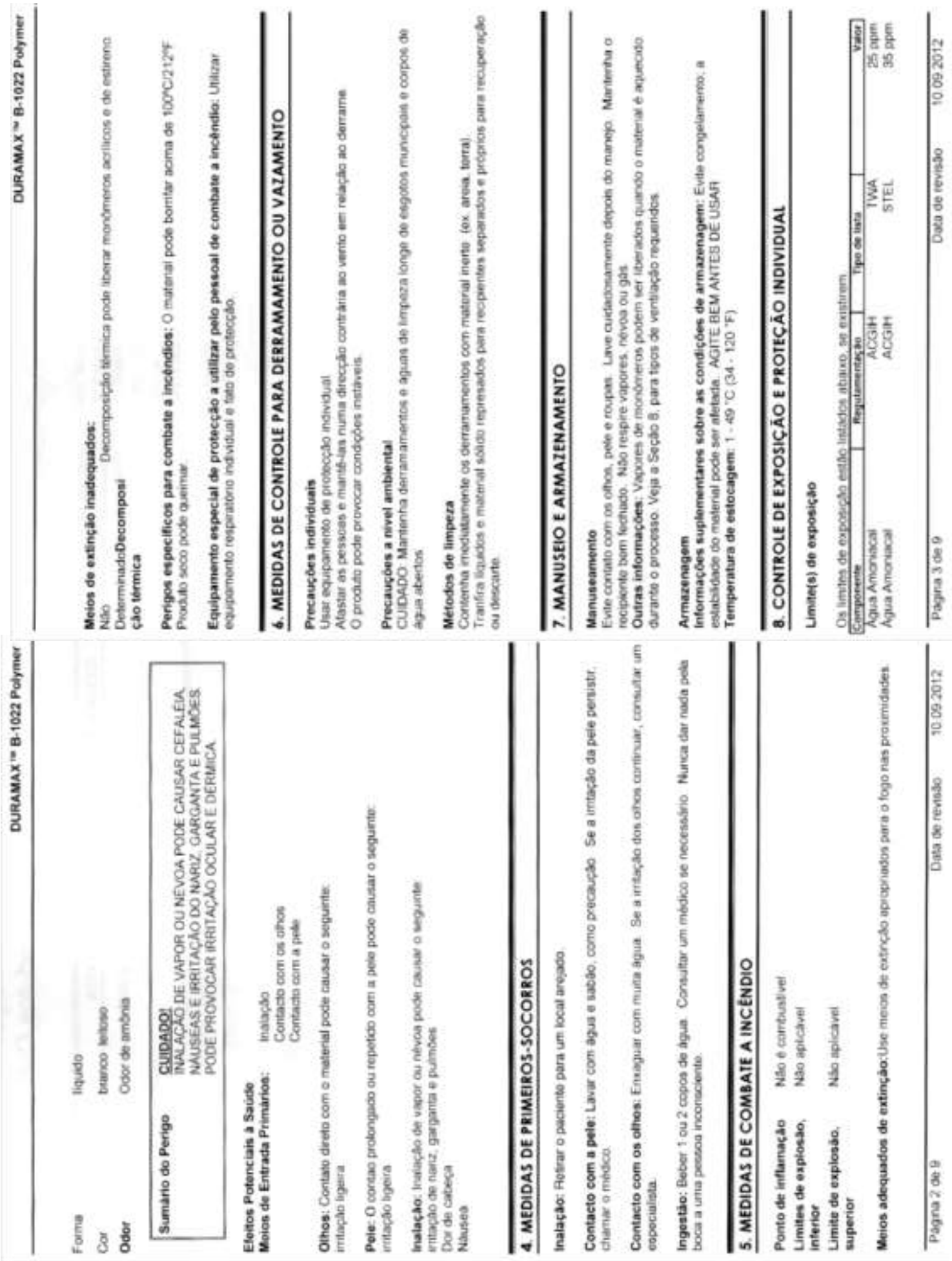




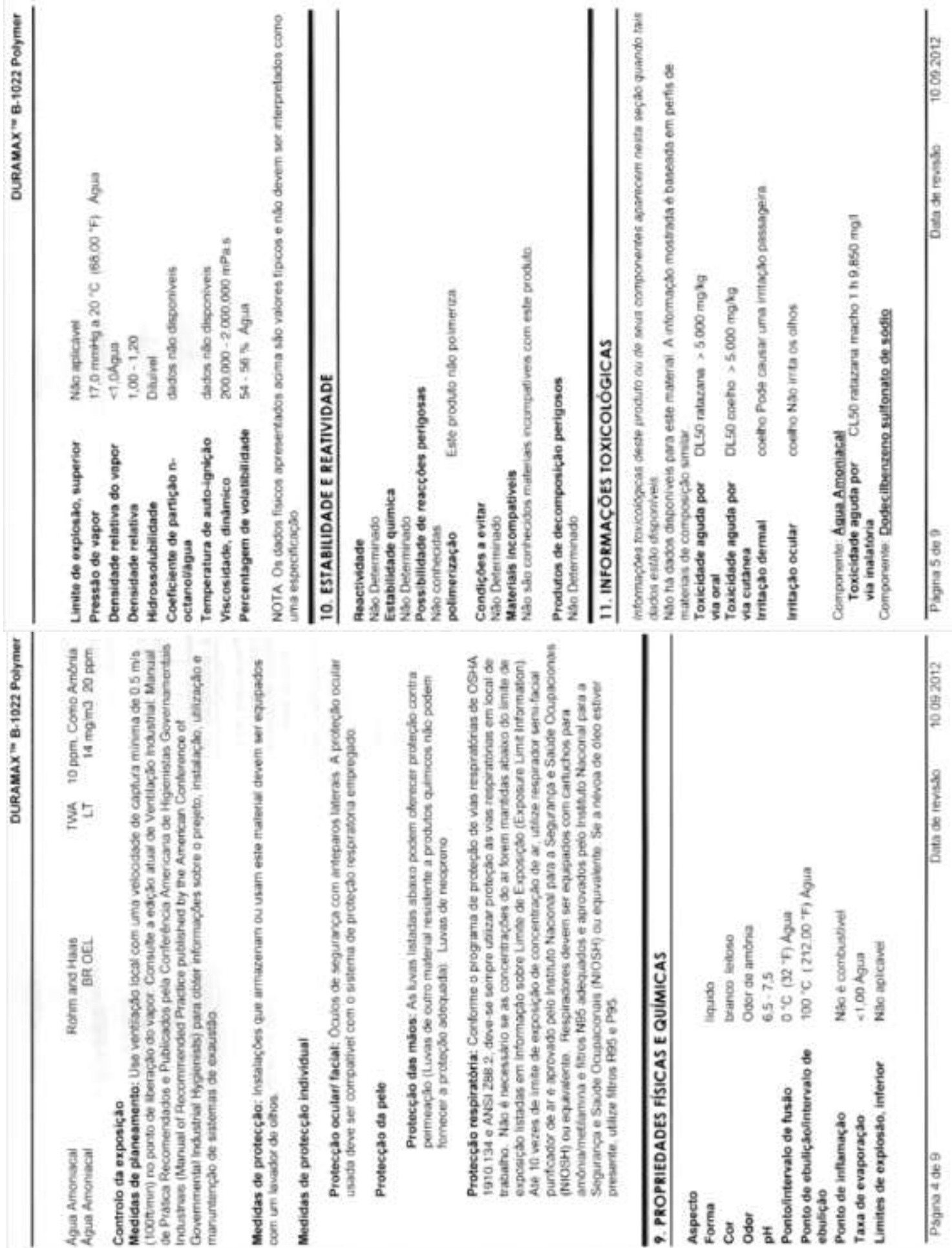




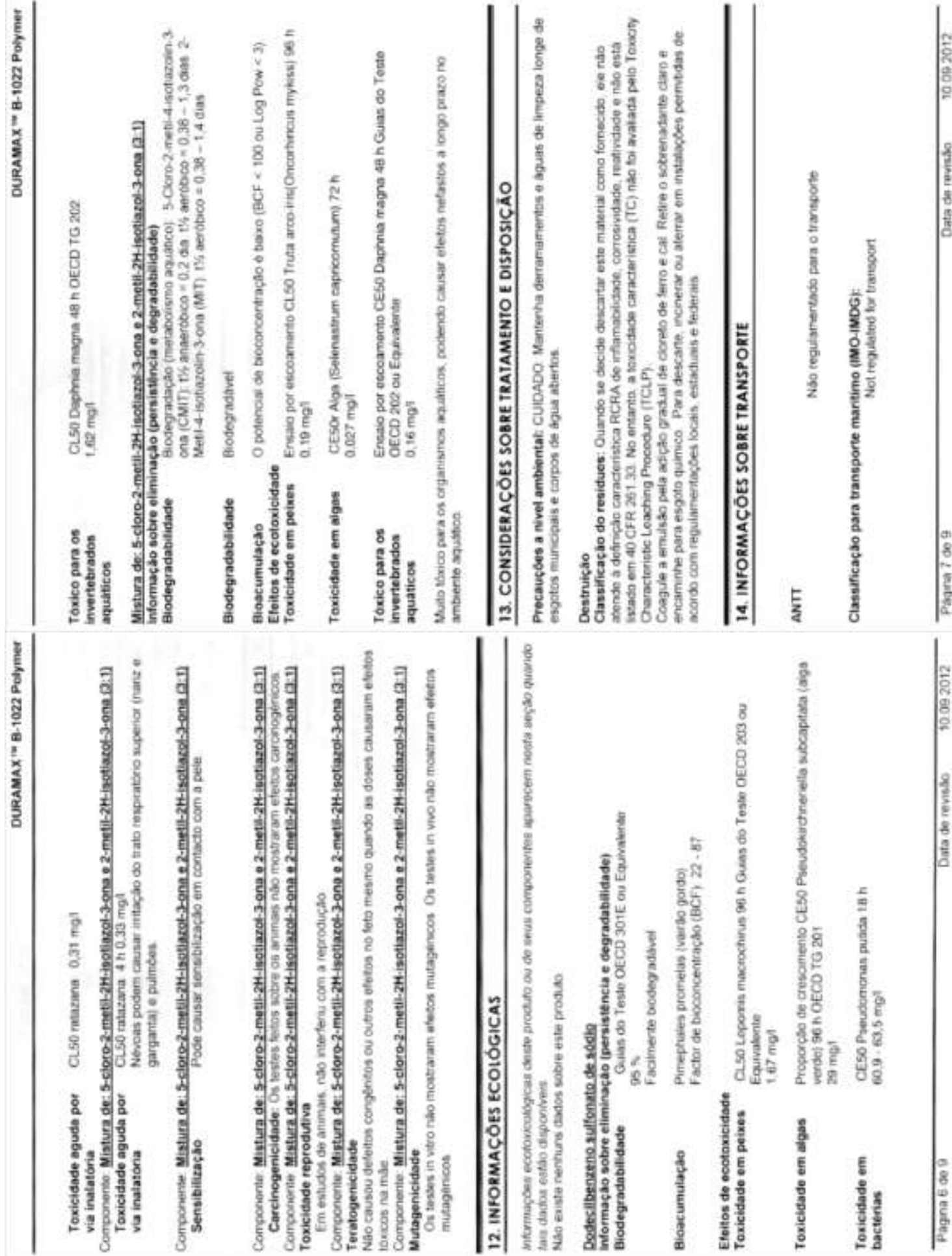



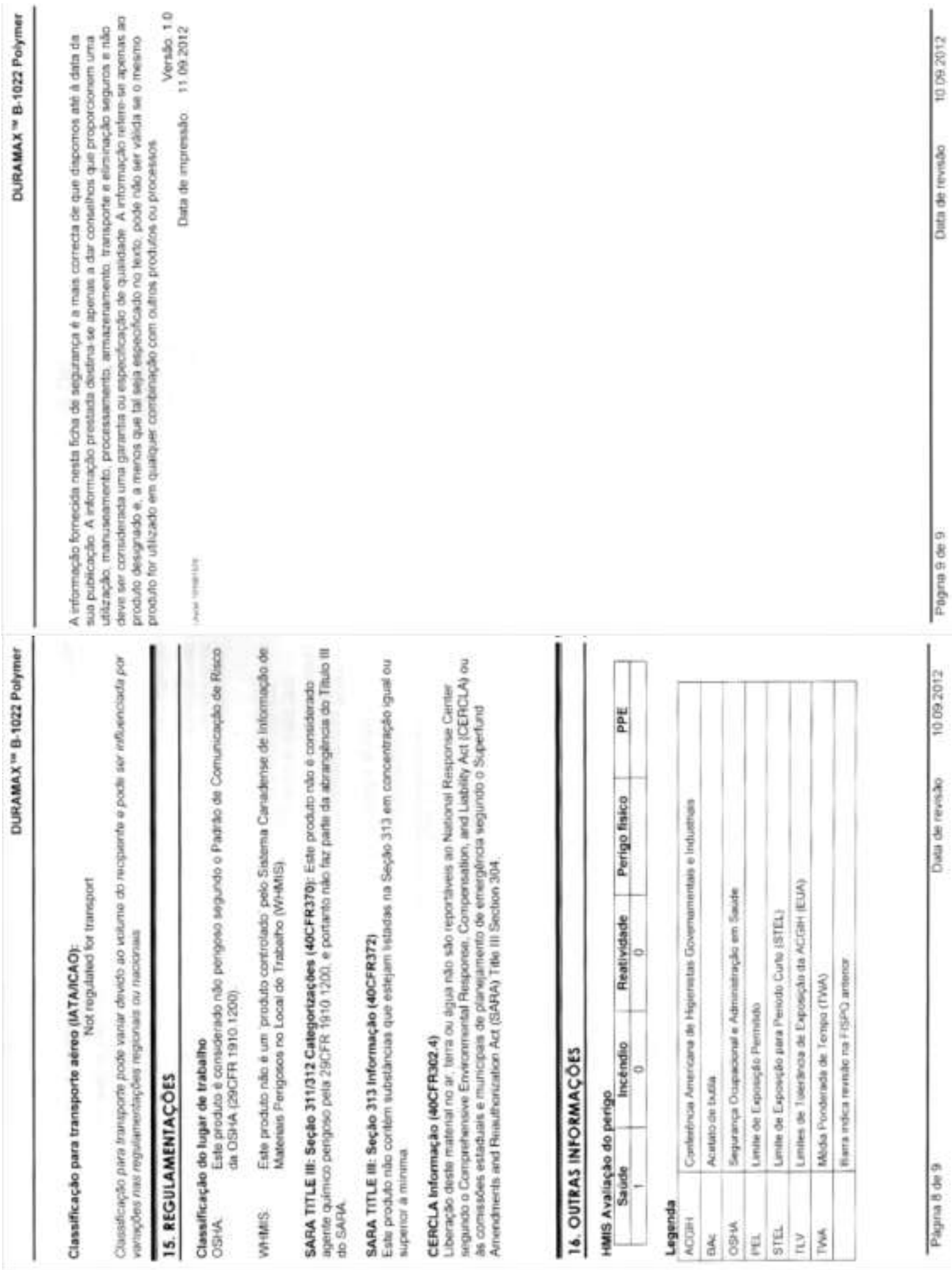

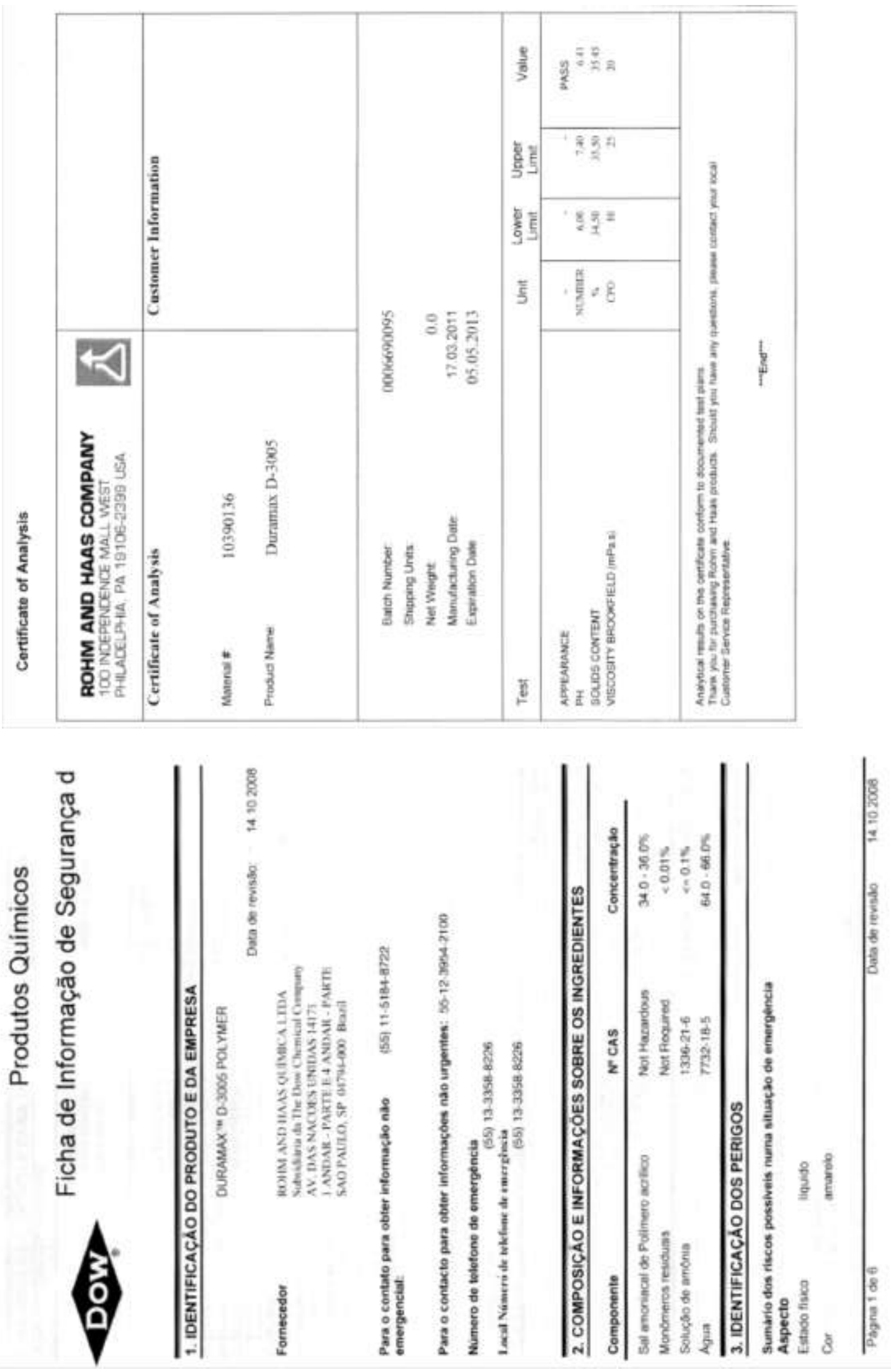


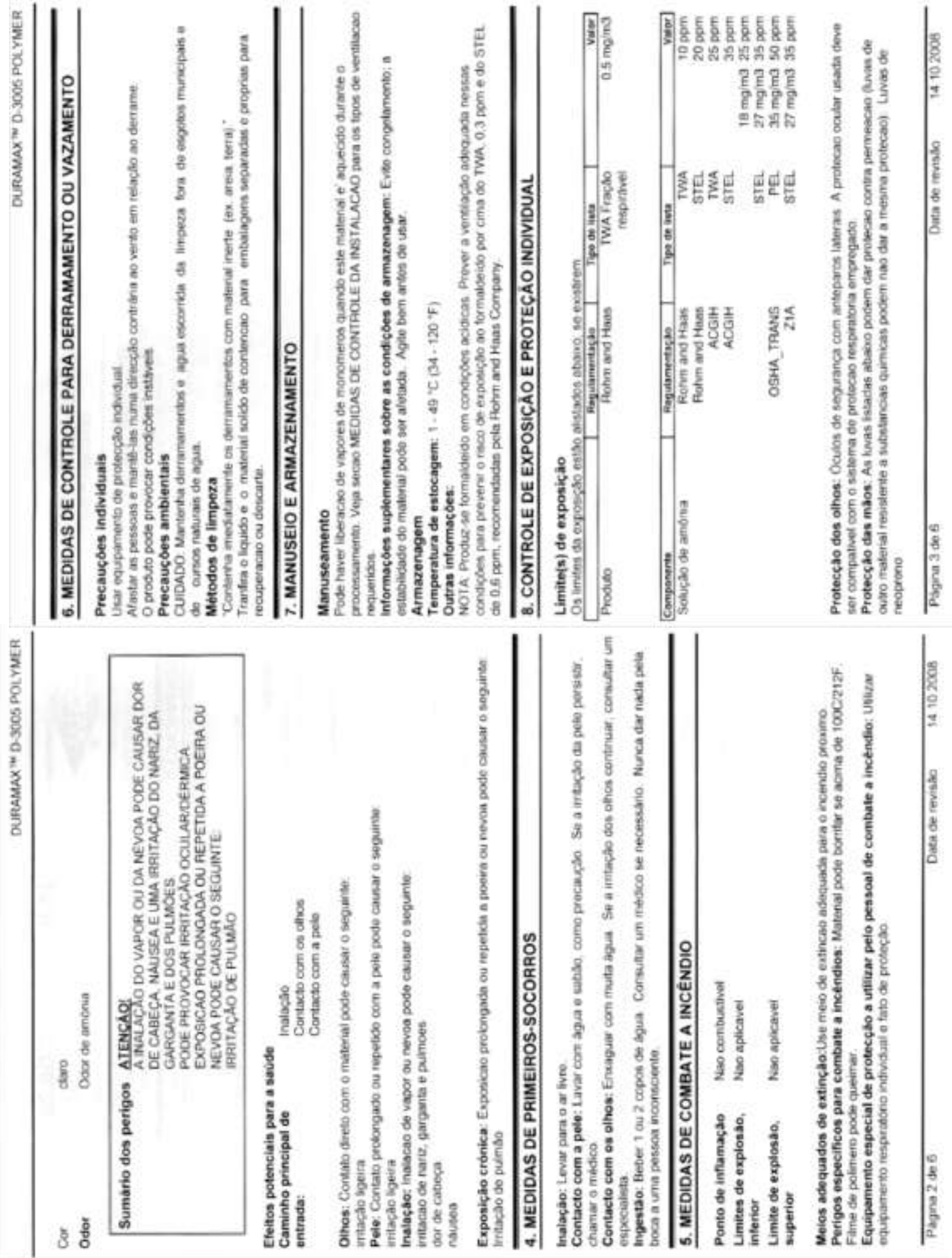




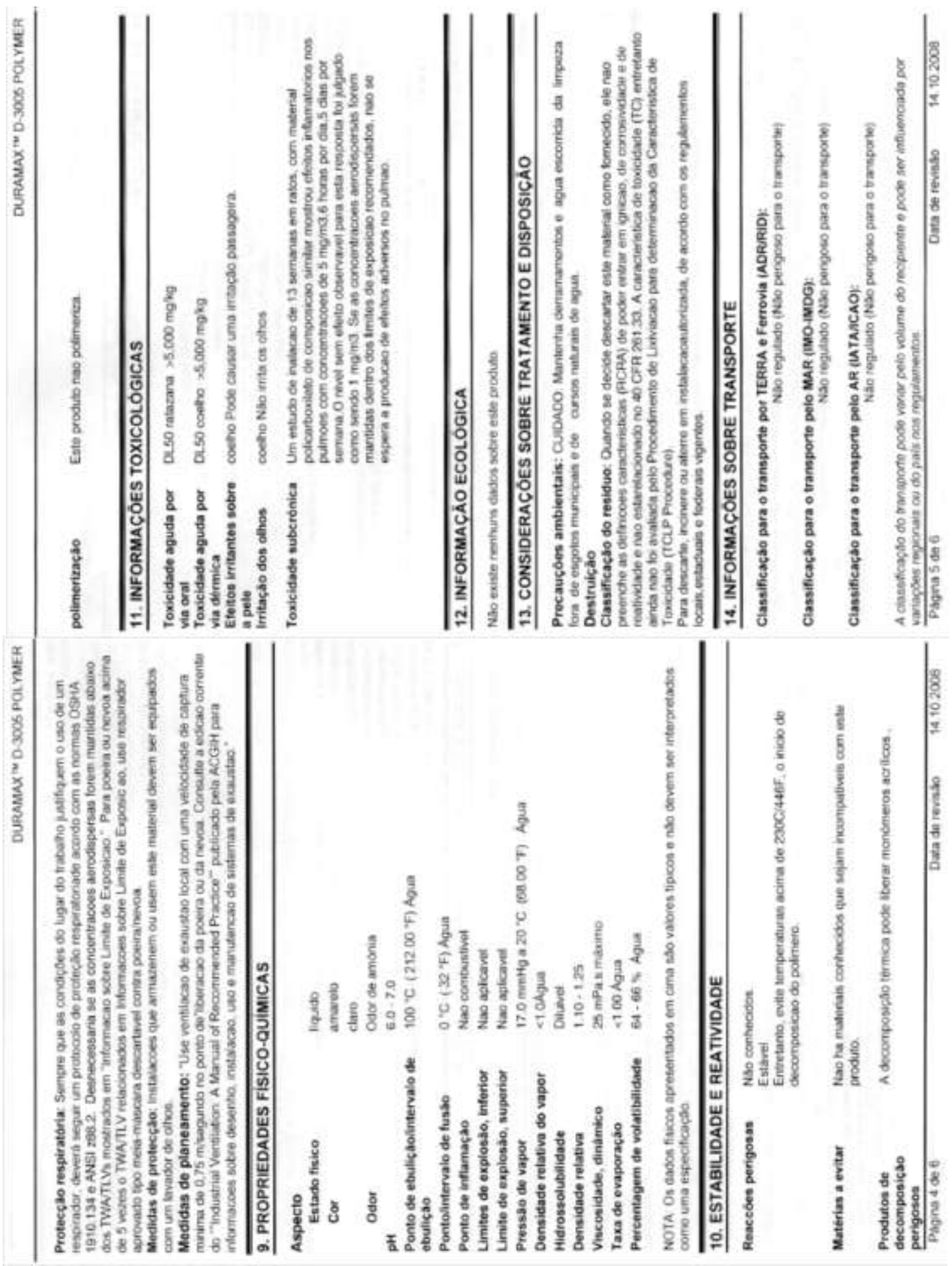




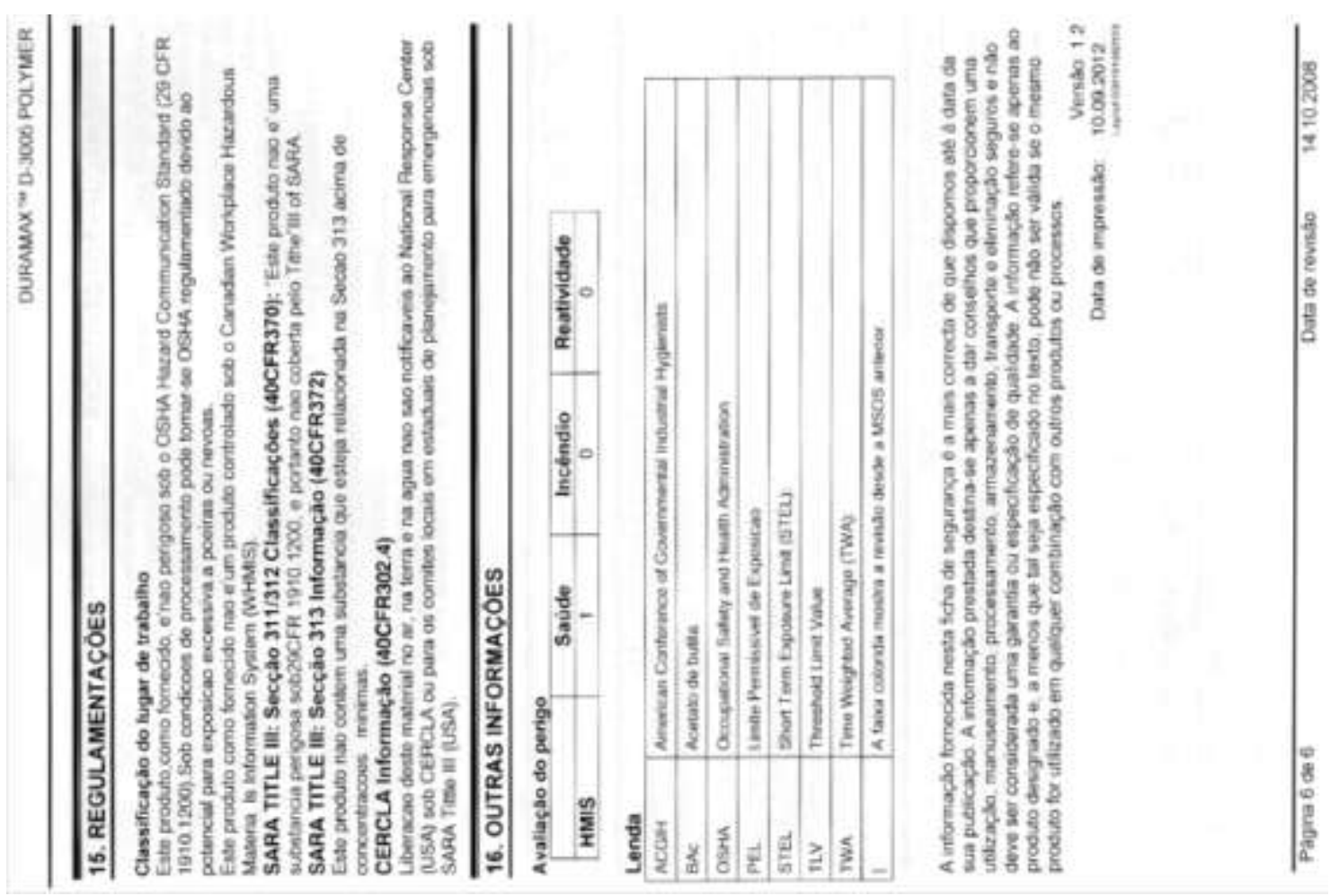

